Editora Poisson

(organizadora)

\title{
Série Educar - Volume 16 Ensino Superior
}

\author{
1a Edição
}

Belo Horizonte

Poisson 


\section{Editor Chefe: Dr. Darly Fernando Andrade}

\section{Conselho Editorial}

Dr. Antônio Artur de Souza - Universidade Federal de Minas Gerais

Ms. Davilson Eduardo Andrade

Dra. Elizângela de Jesus Oliveira - Universidade Federal do Amazonas

Msc. Fabiane dos Santos

Dr. José Eduardo Ferreira Lopes - Universidade Federal de Uberlândia

Dr. Otaviano Francisco Neves - Pontifícia Universidade Católica de Minas Gerais

Dr. Luiz Cláudio de Lima - Universidade FUMEC

Dr. Nelson Ferreira Filho - Faculdades Kennedy

Ms. Valdiney Alves de Oliveira - Universidade Federal de Uberlândia

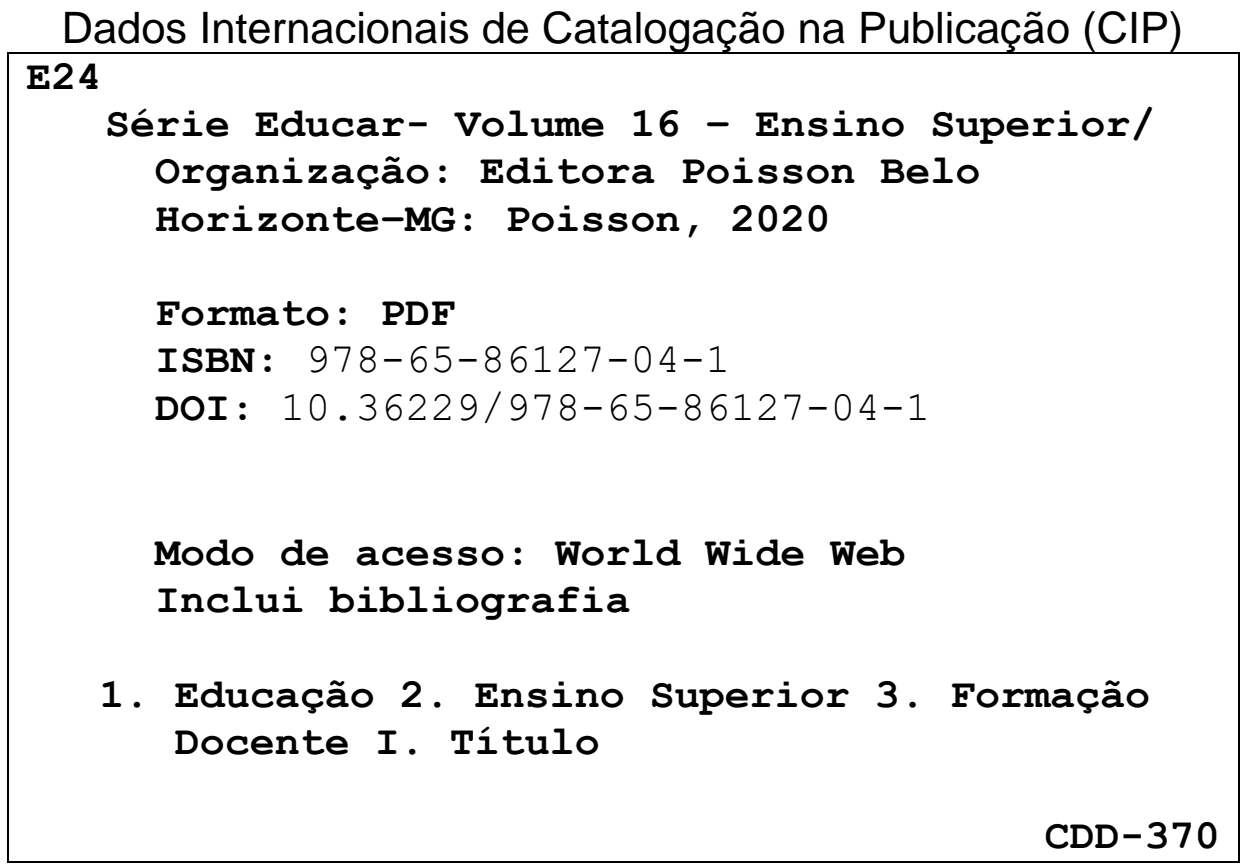

O conteúdo dos artigos e seus dados em sua forma, correção e confiabilidade são de responsabilidade exclusiva dos seus respectivos autores

www.poisson.com.br

contato@poisson.com.br 


\section{SUMÁRIO}

Capítulo 1: A inovação no ensino superior sob a perspectiva dos novos instrumentos de avaliação 08

Antonio Vico Mañas, Luiz Fernando Gomes Pinto

DOI: 10.36229/978-65-86127-04-1.CAP.01

Capítulo 2: Pesquisas desenvolvidas por egressos de um programa de mestrado profissional na área de Educação: Focos e possíveis contribuições para a prática profissional

Maria Lúcia Oliveira Suzigan Dragone, Maria Regina Guarnieri, Dirce Charara Monteiro, Maria Betanea Platzer

DOI: 10.36229/978-65-86127-04-1.CAP.02

Capítulo 3: Concepção de uma turma de licenciandos em química sobre as metodologias de ensino e suas contribuições na formação inicial. 20

Samila Jacinto, Gean Aparecido Zapateiro, Zenaide de Fátima Dante Correia Rocha, Marcia Camilo Figueiredo DOI: 10.36229/978-65-86127-04-1.CAP.03

Capítulo 4: Utilização da sala de aula invertida em cursos de graduação em engenharia 26

Ricardo Luiz Perez Teixeira, Cynthia Helena Soares Bouças Teixeira, Priscilla Chantal Duarte Silva DOI: $10.36229 / 978-65-86127-04-1 . C A P .04$

Capítulo 5: Laboratório de química: Um projeto de monitoria para disciplina de química inorgânica. 34

Aline Joana Rolina Wohlmuth Alves Dos Santos, Charlene Barbosa De Paula DOI: $10.36229 / 978-65-86127-04-1 . C A P .05$

Capítulo 6: Aplicação da metodologia PBL (Problem Based Learning) em uma disciplina inicial dos cursos de Engenharia Civil 38

Juan Carlos Gerez, Gabriele Azambuja Coelho Rodrigues, Karoline Pereira Fagundes, Lucas Gonçalves de Freitas, Bianca Pereira Moreira Ozório DOI: $10.36229 / 978-65-86127-04-1 . C A P .06$

Capítulo 7: PBL e inteligência artificial aplicados na inovação da educação à distância 44 


\section{SUMÁRIO}

Capítulo 8: Um estudo sobre os interesses de alunos de engenharia mecânica na modalidade EAD - estratégias pedagógicas de ensino.

Bruna Gonçalves de Souza, Eduardo Costa Estambasse, Rennan Otavio Kanashiro DOI: $10.36229 / 978-65-86127-04-1 . C A P .08$

Capítulo 9: Educação Presencial x Educação a Distância em cursos de engenharia civil: Análises e reflexões sobre cargas horárias

Jesimiel Pinheiro Cavalcante, Eliedson Rafael de Carvalho, Juliana Lira Brito, Mallena Soares da Silva, Amanda Thais Passos Cordeiro Cavalcante DOI: $10.36229 / 978-65-86127-04-1 . C A P .09$

Capítulo 10: A aquisição de competências humanas sob a percepção dos alunos de um curso superior semipresencial de logística - Um estudo de caso. 67

Alessandra de Paula, Elton Ivan Schneider, Luciano Furtado Corrêa Francisco, Roberto Candido Pansonato, Robson Seleme, Rosinda Angela da Silva DOI: $10.36229 / 978-65-86127-04-1 . C A P .10$

Capítulo 11: Nova forma de aprender dermatologia: Oportunidade de inovação a partir da reforma curricular na graduação de Medicina. 74

Ana Maria Rodrigues dos Santos, José Ricardo Costa Basilio, Attilio Valentini, Fatima Maria Alves Minuzzo, Luciana Teixeira Velloso, Aline Albino Quintanilha Faver DOI: 10.36229/978-65-86127-04-1.CAP.11

Capítulo 12: Percepção dos alunos do curso de Ciências Biológicas da Universidade Estadual do Ceará sobre os mecanismos de avaliação aplicados na Universidade...... 81

Maria Elvira Silva de Sousa, Francisca Amanda da Silva Martins, Amanda Mendes Gomes, Jeanne Barros Leal de Pontes Medeiros

DOI: 10.36229/978-65-86127-04-1.CAP.12

Capítulo 13: Proposta para a utilização de softwares de modelagem e simulação no curso de Engenharia de Produção

Douglas Soares Agostinho, Marcos Wurzer, Vitor Hugo Lopes Lau

DOI: 10.36229/978-65-86127-04-1.CAP.13

Capítulo 14: 0 Ensino do Building Information Model (BIM) em uma instituição de ensino: Um estudo de caso. 


\section{SUMÁRIO}

Capítulo 15: Alunos ingressantes e risco de evasão: Uma aplicação do modelo de tinto no curso de ciências contábeis da UFRN. 102

Daniele da Rocha Carvalho, Franklyn Kennedy da Silva, Ridalvo Medeiros Alves de Oliveira DOI: 10.36229/978-65-86127-04-1.CAP.15

Capítulo 16: 0 programa de aprendizagem cooperativa em células estudantis e a evasão estudantil no campus Russas da Universidade Federal do Ceará 111

Gabrielle dos Santos Marques, Dmontier Pinheiro Aragão Júnior, Marcos Ronaldo Albertin, Leonardo Melo Bezerra

DOI: $10.36229 / 978-65-86127-04-1 . C A P .16$

Capítulo 17: Da universidade ao mercado de trabalho: Análise de aspectos para a contratação e desenvolvimento de carreira dos Engenheiros

Filipe Molinar Machado, Franco da Silveira, Luis Cláudio Villani Ortiz, Bruno Miranda dos Santos, Paulo Cesar Chagas Rodrigues

DOI: $10.36229 / 978-65-86127-04-1 . C A P .17$

Capítulo 18: Perfil do engenheiro eletricista - Impactos da formação acadêmica na atuação profissional 126

Lucas Vinicios Oliveira Filgueiras, Danielly Norberto Araujo, Talvanes Meneses Oliveira DOI: $10.36229 / 978-65-86127-04-1 . C A P .18$

Capítulo 19: Prepare melhor o estudante para um futuro incerto: Incorpore Soft Skills no ensino contábil

José Dutra de Oliveira Neto, Luciano Bastos de Carvalho

DOI: 10.36229/978-65-86127-04-1.CAP.19

Capítulo 20: Escritório habitar: Elaboração de projetos técnicos em engenharia destinado à população de baixa renda através da extensão universitária

Ana Lídia Alencar Vasconcelos, Ana Verônica Gonçalves Borges, Edenia Nascimento Barros, Engels

Zalmom de Carvalho Lacerda, Erwin Ulises Lopez Palechor, Marcelo de Sousa Alves, Simon Sabino Jacó do Nascimento

DOI: $10.36229 / 978-65-86127-04-1 . C A P .20$

Capítulo 21: A possibilidade de um novo olhar para o que está ao seu redor, com Daseinsanálise 


\section{SUMÁRIO}

Capítulo 22: Direita ou esquerda? Como está sua lateralidade? - Um estudo envolvendo acadêmicos do curso de pedagogia da UFPI 153

Raylane Virginia Venancio Ferreira Lima, Antonia Shirley Ferreira dos Santos Brito, Antonia Sandra Veras Lélis, Dionis de Castro Dutra

DOI: $10.36229 / 978-65-86127-04-1 . C A P .22$

Capítulo 23: Aspectos identitários das primeiras turmas de alunos do campus da Uece de Tauá 159

João Álcimo Viana Lima

DOI: $10.36229 / 978-65-86127-04-1 . C A P .23$

Capítulo 24: Fatores sóciodemográficos do envelhecimento e as universidades da terceira idade

Vânia Maria Henrique Lima

DOI: $10.36229 / 978-65-86127-04-1 . C A P .24$

Autores: 


\section{Capítulo 1}

\section{A inovação no ensino superior sob a perspectiva dos novos instrumentos de avaliação}

\section{Antonio Vico Mañas \\ Luiz Fernando Gomes Pinto}

Resumo: Em 31 de outubro de 2017 foram publicadas as Portarias 1.382 e 1.383, relativas aos novos instrumentos de avaliação de cursos de graduação para os atos de autorização, reconhecimento e renovação de reconhecimento nas modalidades presencial e a distância. Nesse novo instrumento de avaliação institucional aparece o termo "práticas exitosas ou inovadoras" (Inep, 2017b, p. 52). Este artigo tem como objetivo analisar as inovações realizadas pelas Instituições de Ensino Superior (IES) com base nos novos instrumentos de avaliação e sua contribuição para a melhoria da qualidade no processo de ensino e aprendizagem, considerando-se cursos oferecidos na modalidade presencial e especialmente pela modalidade a distância (e-learning). Apresenta-se o resultado obtido em uma pesquisa de campo desenvolvida em um número relevante de IES, representadas por seus docentes, coordenadores, diretores e componentes das reitorias. Espera-se que este estudo sobre inovação no contexto educacional possa contribuir de alguma forma para se alcançar a meta 12 do Plano Nacional de Educação (PNE), de elevar, até 2024, a taxa bruta de matrícula na educação superior para 50\% e a taxa líquida para 33\% da população de 18 a 24 anos (SASE, 2014). Vale ressaltar que, segundo dados de 2015 , apenas $18,1 \%$ das pessoas na faixa etária de 18 a 24 anos estavam no ensino superior, o que implica que para alcançar a meta do PNE é necessário aumentar o número de alunos em aproximadamente três milhões (Inep, 2017a).

Palavras-chave: Ensino Superior; Inovação Educacional; Instrumentos de Avaliação. 


\section{INTRODUÇÃO}

O objetivo deste estudo é avaliar as inovações realizadas e implantadas nas Instituições de Ensino Superior sob a perspectiva dos novos instrumentos de avaliação do ensino superior no Brasil. A etapa bibliográfica da pesquisa destacou a publicação em dezembro de 2017 do Decreto no 9.235 , referente à regulação, à supervisão e à avaliação das IES, no qual a inovação foi incluída nos instrumentos de avaliação como um dos fatores de promoção de qualidade do ensino superior.

Este artigo enfoca a identificação da inovação realizada e implantada nas Instituições de Ensino Superior (IES), com base nos aspectos de inovação considerados no novo instrumento de avaliação das IES.

Com base na análise bibliográfica e em uma pesquisa exploratória com enfoque descritivo qualitativo, direcionada para representantes das instituições de ensino superior, verificou-se que as inovações pertinentes ao ensino superior e a aprendizagem, em especial na modalidade presencial, enfatizam o próprio uso das tecnologias da informação e da comunicação, assim como de práticas instrucionais que já são aplicadas em várias instituições de ensino no País.

As inovações ou práticas inovadoras relatadas pelos representantes das instituições participantes da pesquisa indicam a implantação de uma nova prática para a respectiva instituição, mas não necessariamente para todo o universo de instituições de ensino.

\section{0 SISTEMA DE AVALIAÇÃO DA EDUCAÇÃO SUPERIOR NO BRASIL}

No Brasil, em 2017, havia 2.448 Instituições de Ensino Superior (IES), sendo 296 instituições públicas $(22,1 \%)$ e 2.152 privadas $(87,9 \%)$. A rede pública participa com $24,7 \%$ (2.045.356) no total de matrículas de graduação, enquanto que as IES privadas têm uma participação de 75,3\% (6.241.307) no total de matrículas de graduação. Entre 2007 e 2017, o número de ingressantes variou positivamente 19,0\% nos cursos de graduação presencial e 226,0\% nos cursos a distância. Em 2017, houve um crescimento de 8,1\% em relação a 2016 no número de ingressantes, ocasionado, principalmente, pela modalidade a distância, que teve uma variação positiva de $27,3 \%$ entre esses anos, enquanto nos cursos presenciais houve um acréscimo de $0,5 \%$.

Nos cursos na modalidade a distância, mais de 46\% das matrículas são de cursos tecnológicos. Entre 2007 e 2017 as matrículas na modalidade a distância cresceram mais de 586\% em relação à variação positiva de $54,1 \%$ no número de matrículas de cursos presenciais no mesmo período. As matrículas em cursos de graduação presenciais de grau tecnológico mantêm a tendência de queda registrada desde 2013.

Com o objetivo que a expansão da educação superior no Brasil ocorra dentro de padrões de qualidade, em 2004 foi instituído o Sistema Nacional de Avaliação da Educação Superior (Sinaes), que tem como finalidade a melhoria da qualidade da educação nos cursos de graduação e instituições por meio de políticas públicas educacionais da educação superior direcionadas pelo princípio constitucional da garantia de padrão de qualidade, previsto no art. 206, inciso VII da Constituição Federal de 1988 (Inep, 2017c).

Para ofertar educação superior, as faculdades privadas devem solicitar ao Instituto Nacional de Estudos e Pesquisas Educacionais Anísio Teixeira (Inep), órgão vinculado ao Sinaes, o seu credenciamento e posteriormente devem se submeter a processo avaliativo para obter o recredenciamento, necessário para a continuidade da oferta (Inep, 2017c).

Depois de credenciada, para poder ofertar um curso de graduação, as faculdades devem solicitar autorização para cada curso. Após o curso ser autorizado e alcançado cinquenta por cento do período de integralização, os cursos passam pelo ato de reconhecimento, que possibilitará a IES emitir diplomas aos graduados. Posteriormente, de acordo com a legislação pertinente, as instituições se submetem a processo avaliativo periódico para obter a renovação do reconhecimento, necessário para a continuidade da oferta (Inep, 2017c).

Para realizar tais atos autorizativos, há instrumentos distintos, os instrumentos de avaliação externa para credenciamento das IES e os instrumentos para autorização e reconhecimento de cursos superiores de graduação. Esses instrumentos avaliam três dimensões: organização didático-pedagógica, corpo docente e tutorial e infraestrutura. Ao final da avaliação do curso é gerado o Conceito de Curso, graduado em cinco níveis (conceitos de 1 a 5). 0 conceito 3 indica qualidade satisfatória, conceitos abaixo de 3 indicam qualidade insatisfatória e conceitos entre 4 e 5 indicam que a IES ou o curso avaliado superam a qualidade satisfatória (Inep, 2017c, 2017c). 
Em 31 de outubro de 2017 foram publicados as Portarias 1.382 e 1.383, relativa aos instrumentos de avaliação de cursos de graduação para os atos de autorização, reconhecimento e renovação de reconhecimento nas modalidades presencial e a distância. Com a nova portaria, há objetos de análise distintos nos instrumentos de avaliação para avaliar os cursos de graduação presencial e para avaliar os cursos a distância. Além disso, os pesos atribuídos a cada uma das três dimensões também sofreram modificações, apresentando pesos distintos para o ato de autorização e para os atos de reconhecimento e renovação (SEMESP, 2018).

De acordo com relatórios estatísticos dos dados de linguagem coletados dos instrumentos de avaliação externa publicados em 2015 e 2017 elaborado pelo SEMESP (2018), a palavra "inovação" pela primeira vez está presente no instrumento de avaliação externa, são 16 citações no novo instrumento publicado em 2017 contra nenhuma do antigo instrumento publicado em 2015.

Segundo a Organização para a Cooperação e Desenvolvimento Econômico (OCDE, 2014), a inovação educacional é um fator importante para melhorar os resultados de aprendizagem e a qualidade da educação, tema que será abordado mais especificamente na subseção a seguir.

\section{A INOVAÇÃO NO ENSINO SUPERIOR}

A inovação, segundo o economista Schumpeter (1996), é o fenômeno fundamental do desenvolvimento econômico, devido ao fato de promover a "destruição criativa", isto é, a substituição de antigos produtos e hábitos de consumir por novos. A visão Schumpeteriana de inovação está associada à inovação radical, ou seja, aquela que resulta em um produto superior em relação aos produtos existentes, os quais tornam-se menos competitivos. Porém, a inovação também pode ser incremental, que considera as melhorias técnicas realizadas em produtos ou processos após a sua introdução no mercado.

Na inovação educacional também pode-se considerar dois tipos de abordagens de inovação: substituição e transformação. A inovação por substituição é caracterizada por passos incrementais. Já a abordagem transformacional baseia-se na descontinuidade com base em avanços tecnológicos, bem como novas perspectivas sobre o que ensinar e com respeito ao perfil dos alunos (OECD, 2014).

A Organização para a Cooperação e Desenvolvimento Econômico (OCDE, 2005), com o intuito de ter um parâmetro geral para medir a inovação nos diversos setores econômicos, elaborou o Manual de Oslo com quatro parâmetros de inovação: (1) implementação de um produto ou serviço novo ou significativamente melhorado no mercado; (2) um processo novo ou significativamente melhorado; (3) novas técnicas de marketing; e (4) novos métodos de práticas organizacionais, no ambiente organizacional ou nas suas relações externas.

Para adequar os parâmetros gerais as especificidades da inovação educacional, um estudo do "Centro para Pesquisa Educacional e Inovação" recomenda a inclusão de duas categorias específicas: inovações em práticas em sala de aula e práticas institucionais (OECD, 2014). As inovações em "sala de aula" contemplam três dimensões: práticas instrucionais, recursos educacionais e disponibilidade de recursos para o ensino. As práticas institucionais compreendem políticas educacionais e os tomadores de decisão da organização (reitores, diretores, conselhos). Contemplam práticas que podem afetar os alunos diretamente, como a disponibilização de programas especiais, ou indiretamente, por meio de novas práticas organizacionais ou de gestão dos recursos humanos, ou novos meios de engajamento ou relacionamento com os pais dos alunos.

Nos glossários dos novos instrumentos de avaliação institucional externa presencial e a distância para credenciamento e recredenciamento de cursos aparece o termo "inovação tecnológica", que trata do processo de invenção, adaptação, mudança ou evolução da atual tecnologia, melhorando e facilitando a vida ou o trabalho das pessoas. Ainda nesse instrumento aparece o termo "ação inovadora", que está relacionado a "adoção de práticas e procedimentos que oportunizem a criação ou o desenvolvimento de novos produtos ou ideias e permitam a melhoria de processos, apontando para ganhos de eficiência e para a adaptação inédita a situações que se apresentem" (Inep, 2017c, p. 33). 
No glossário do novo instrumento de avaliação institucional externa para autorização de curso de graduação presencial e a distância publicado em 2017 (Inep, 2017b, p. 52), aparece o termo "práticas exitosas ou inovadoras":

São aquelas que a IES/Curso encontrou para instituir uma ação de acordo com as necessidades da sua comunidade acadêmica, seu PDI e seu PPC, tendo como consequência o êxito do objetivo desejado. Podem ser também inovadoras quando se constatar que são raras na região, no contexto educacional ou no âmbito do curso. Para isso, o Curso ou a IES podem se valer de recursos de ponta, criativos, adequados ou pertinentes ao que se deseja alcançar.

Como citado na seção anterior, os instrumentos de avaliação contemplam três dimensões das instituições de educação superior e dos cursos superiores de graduação: organização didático-pedagógica, corpo docente e tutorial e infraestrutura. Nos objetos de avaliação da dimensão 1, organização didáticopedagógica, para se obter o conceito 5 o curso deve apresentar algum tipo de prática exitosa ou inovadora, conforme destacado a seguir (Inep, 2017b):

- Indicador 1.1 Políticas institucionais no âmbito do curso: As políticas institucionais de ensino, extensão e pesquisa (quando for o caso), constantes no Plano de Desenvolvimento Institucional (PDI), estão previstas no âmbito do curso e claramente voltadas para a promoção de oportunidades de aprendizagem alinhadas ao perfil do egresso, pressupondo-se práticas exitosas ou inovadoras para a sua revisão.

- Indicador 1.6 Metodologia: A metodologia, prevista no PPC (e de acordo com as DCN, quando houver), atende ao desenvolvimento de conteúdos, às estratégias de aprendizagem, ao contínuo acompanhamento das atividades, à acessibilidade metodológica e à autonomia do discente, coaduna-se com práticas pedagógicas que estimulem a ação discente em uma relação teoria-prática, e é claramente inovadora e embasada em recursos que proporcionem aprendizagens diferenciadas dentro da área.

- Indicador 1.12 Apoio ao discente: A previsão de apoio ao discente contempla ações de acolhimento e permanência, acessibilidade metodológica e instrumental, monitoria, nivelamento, intermediação e acompanhamento de estágios não obrigatórios remunerados, apoio psicopedagógico, participação em centros acadêmicos ou intercâmbios nacionais e internacionais, e ações inovadoras.

\section{METODOLOGIA}

Para o desenvolvimento deste estudo realizou-se uma pesquisa bibliográfica, acompanhada de uma pesquisa exploratória de campo, com enfoque descritivo qualitativo. A pesquisa seguiu as definições da OECD (2014) e abordou as inovações de práticas em sala de aula e práticas institucionais.

A coleta dos dados se deu por meio do envio da pesquisa por e-mail a representantes de instituições de ensino de superior (Faculdades, Centros Universitários e Universidades) predominantemente do Estado de São Paulo, em razão de ser a região onde há maior concentração de instituições de ensino superior, assim como por ser a região mais populosa e com maior representatividade no PIB. Vale destacar que, apesar do MEC permitir desde o final de 2017 a criação de cursos totalmente a distância, no período de realização da pesquisa ainda não havia nenhuma instituição com tal formato.

A OECD (2014), recomenda que para as pesquisas de inovação seja utilizado a abordagem de "mudanças organizacionais", que consiste na aplicação da pesquisa para três níveis de envolvidos no processo educacional: diretores, docentes e discentes. Devido a restrição das instituições pesquisadas, a presente pesquisa restringiu-se a diretores, coordenadores de curso e professores, inclusive tutores.

Participaram da pesquisa 31 respondentes, de 19 instituições de ensino superior, sendo 7 delas universidades, 11 centros universitários e 1 faculdade. Das 19 instituições pesquisadas, 16 delas possuem cursos presenciais e na modalidade on-line; 2 delas possuem cursos somente presenciais; e uma delas cursos presenciais e híbridos, isto é, parte oferecida presencialmente e parte on-line. É importante destacar que das 19 instituições pesquisadas, 18 delas são privadas e confessionais e 1 delas é pública, a Universidade de São Paulo (USP).

O questionário contém perguntas fechadas e abertas e foi estruturado com duas seções, sendo uma delas para avaliar as instituições que possuem somente cursos na modalidade presencial e outra seção para aquelas que além da modalidade presencial, possui também a modalidade totalmente a distância. 


\section{ANÁLISE DOS RESULTADOS DA PESQUISA}

O primeiro tema analisado pela pesquisa foi a percepção da importância da inovação para a qualidade do ensino superior. Segundo os diretores e professores das instituições de ensino superior, as ações inovadoras são consideradas importantes para a qualidade, tanto para os cursos presenciais como a distância. Dos 31 participantes da pesquisa, 22 deles consideraram as ações inovadoras importante ou totalmente importante para a qualidade dos cursos presenciais. A mesma percepção ocorre para os cursos na modalidade $a$ distância: 23 consideraram as ações inovadoras importante ou totalmente importante para a qualidade dos cursos.

Esse resultado vai ao encontro de uma pesquisa realizada pelo Censo da Educação de 2016 da ABED (2017) junto a representantes das instituições de ensino superior privadas. Perguntados sobre os desafios do ensino a distância (EaD) no País, com base em escala Likert de 1 - 5, houve um índice de concordância de 4,64 com relação a afirmação de que a EAD exige inovação em abordagens pedagógicas; seguida por um índice de concordância de 4,60 quanto a afirmação de que a modalidade EaD exige inovação tecnológica constante; e um índice de concordância de 4,27 para as afirmações de que a EaD exige inovação de processos administrativos e alto padrão de infraestrutura.

O segundo tema analisado toma como base as definições de inovação segundo a OCDE (2014): as inovações em sala de aula, que contempla as práticas instrucionais, recursos educacionais e disponibilidade de recursos para o ensino; e as práticas institucionais, que compreendem políticas educacionais e os tomadores de decisão da organização (reitores, diretores, conselhos).

Com relação as inovações em sala de aula, a pesquisa revela que o uso do recurso de fórum assíncrono, de biblioteca virtual e de aplicativos educacionais são os fatores mais associados a inovação relativa a recursos educacionais, tanto para cursos na modalidade presencial como para a modalidade a distância. Considerando-se somente os 21 representantes das 19 instituições que possuem cursos na modalidade a distância, 19 dos respondentes concordam parcialmente ou concordam totalmente que o fórum é um importante recurso de comunicação para a aprendizagem do aluno; a webconferência é a segunda ferramenta mais importante, com 18 dos respondentes indicando que concordam parcialmente ou concordam totalmente que essa ferramenta também é um importante recurso de comunicação para a aprendizagem do aluno.

Com relação a práticas instrucionais inovadoras, para cursos nas modalidades presencial e a distância, as instituições participantes da pesquisa indicaram a implantação de metodologias ativas, como, por exemplo, sala de aula invertida. Indicou-se também o uso de gamificação, jogos de empresas e a Aprendizagem Baseada em Problemas.

Quanto à implantação de algum tipo de novas práticas organizacionais ou de gestão dos recursos humanos inovadora, foi citado pela maioria dos respondentes o treinamento dos profissionais para a modalidade a distância e a realização de reuniões, cursos e workshops objetivando desenvolver o potencial de gestores, professores, auxiliares de ensino, tutores, monitores e estagiários, assim como subsidiá-los dos objetivos e propósitos da IES. Com menor destaque, citou-se também a gestão de performance por indicadores de percepção e operacionais em ciclos semestrais e a contratação de tutores terceirizados, com base em sua experiência profissional prática e aderente a disciplina.

Avaliando-se o conjunto dos resultados da pesquisa, apesar da importância atribuída a inovação para a qualidade do ensino, verifica-se que os tipos de inovação educacional relatados pelos pesquisados, em especial as novas práticas instrucionais e organizacionais, indicam inovações incrementais. Ou seja, não houve nenhum relato de inovação de abordagem transformacional, que implica na descontinuidade com base em avanços tecnológicos, bem como novas perspectivas sobre o que ensinar (OECD, 2014).

A pesquisa indica que as inovações realizadas pela maioria das instituições refletem a implantação de uma nova prática para a respectiva instituição, mas não necessariamente uma inovação transformacional considerando-se todo o universo de instituições de ensino.

\section{CONSIDERAÇÕES FINAIS}

O objetivo da pesquisa descritiva qualitativa teve como foco a inovação nas IES brasileiras. A análise dessa pesquisa mostra que nos anos recentes as inovações pertinentes ao ensino e a aprendizagem enfatizam o uso das tecnologias da informação e da comunicação. 
A IES ou o curso ou ainda o docente que implanta novas ideias, práticas, métodos, técnicas, de fato está inovando, porém é uma inovação para a própria instituição e não necessariamente é uma novidade para o ambiente educacional ou para a sociedade de maneira geral.

A percepção de diretores, coordenadores, professores e tutores ligados às IES trazem questões que indicam a necessidade de aprofundamento do tema pesquisado e que alimentam possíveis novas pesquisas em futuros próximos. Entre essas questões destacam-se: O que a IES adotou como inovação proporciona efetivamente melhor qualidade do ensino/aprendizagem? Essa qualidade obtida é efetivamente superior ou não àquela obtida antes de ocorrer a inovação?

\section{REFERÊNCIAS}

[1] Inep. Censo da Educação Superior 2017 - Notas Estatísticas. Brasília-DF: Instituto Nacional de Estudos e Pesquisas Educacionais Anísio Teixeira - Inep, 2018. Disponível em: <

http://download.inep.gov.br/educacao_superior/censo_superior/documentos/2018/censo_da_educacao_superior_20 17-notas_estatisticas2.pdf >. Acesso em: 16 fev. 2019.

[2] Inep. Censo da Educação Superior 2016 - Apresentações. Brasília-DF: Instituto Nacional de Estudos e Pesquisas Educacionais Anísio Teixeira - Inep, 2017a. Disponível em:

<http://download.inep.gov.br/educacao_superior/censo_superior/apresentacao/2016/apresentacao_censo_educaca o_superior.pdf>. Acesso em: 16 fev. 2019.

[3] Inep. Instrumentos de avaliação de cursos de graduação presencial e a distância. Brasília: Instituto Nacional de Estudos e Pesquisas Educacionais Anísio Teixeira - Inep, 2017b. Disponível em: <http://portal.inep.gov.br/instrumentos>. Acesso em: 16 fev. 2019.

[4] Inep. Instrumento de avaliação institucional externa presencial e a distância. Brasília: Instituto Nacional de Estudos e Pesquisas Educacionais Anísio Teixeira - Inep, 2017c. Disponível em: <http://portal.inep.gov.br/instrumentos>. Acesso em: 16 fev. 2019.

[5] Organização para a Cooperação e Desenvolvimento Econômico. Measuring innovation in education: a new perspective. Paris: Oecd, 2014. Disponível em: <http://www.keepeek.com/Digital-Asset-

Management/oecd/education/measuring-innovation-in-education_9789264215696-en\#.Wcwpy2hSyM8>. Acesso em: 15 fev. 2019.

[6] Organização para a Cooperação e Desenvolvimento Econômico. Oslo Manual: guidelines for collecting and interpreting innovation data. Paris: Oecd, 2005. Disponível em: < https://read.oecd-ilibrary.org/science-andtechnology/oslo-manual_9789264013100-en\#page3>. Acesso em: 15 fev. 2019.

[7] Mañas, Antônio Vico; Pinto, Luiz F. Gomes. Uma análise dos sistemas de avaliação das IES no Brasil e sua contribuição para a melhoria da qualidade dos processos de ensino e aprendizagem. 8. ${ }^{\text {a }}$ Conferência da Associação FORGES. Lisboa: IPL, 2018. Disponível em: <www.aforges.org>. Acesso em: 2 fev. 2019.

[8] Sase - Secretaria de Articulação com os Sistemas de Ensino. Planejando a Próxima Década: Conhecendo as 20 Metas do Plano Nacional de Educação. Sase, 2014. Disponível em: <http://pne.mec.gov.br/images/pdf/pne_conhecendo_20_metas.pdf>. Acesso em: 15 fev. 2019.

[9] Secretaria de educação a distância. Referenciais de Qualidade para a Educação Superior a Distância. Brasília: Seed - Secretaria de educação a distância, 2007. Disponível em:

<http://portal.mec.gov.br/seed/arquivos/pdf/legislacao/refead1.pdf>. Acesso em: 15 fev. 2019.

[10] Shumpeter, Joseph. Ensaios: empresários, inovação, ciclos de negócios e evolução do capitalismo. Lisboa: Celta Editora, 1996 (Tradução: Maria Inês Mansinho e Ezequiel de Almeida Pinho).

[11] Sindicato das Entidades Mantenedoras de Estabelecimentos de Ensino superior no Estado de São Paulo. Novos instrumentos de avaliação favorecem a inovação nas IES. São Paulo: Semesp, 2018. Disponível em: <http://www.semesp.org.br/wp-content/uploads/2018/01/Novos-instrumentos-de-avalia\%C3\%A7\%C3\%A3ofavorecem-inova\%C3\%A7\%C3\%A3o-nas-IES-1.pdf>. Acesso em: 15 fev. 2019. 


\section{Capítulo 2}

Pesquisas desenvolvidas por egressos de um programa de mestrado profissional na área de Educação: Focos e possíveis contribuições para a prática profissional

\section{Maria Lúcia Oliveira Suzigan Dragone}

\section{Maria Regina Guarnieri}

\section{Dirce Charara Monteiro \\ Maria Betanea Platzer}

Resumo: 0 Mestrado Profissional tem, entre seus objetivos, favorecer a integração entre formação profissional e acadêmica para promover melhorias nas organizações públicas e privadas para solução de problemas e construção de processos inovadores aplicáveis às práticas profissionais (BRASIL, 2017). Essas melhorias decorrem dos estudos teóricos e das investigações científicas desenvolvidas pelos alunos, com perfil de pouca experiência em pesquisa, provavelmente formados teoricamente distanciados de reflexões sobre a prática (Nóvoa, 2007), o que passa a ser um fator preocupante para os programas de mestrado (Cevallos, Passos, 2012). Diante do exposto, o presente trabalho objetiva relatar o perfil das pesquisas desenvolvidas em um Mestrado Profissional na área de Educação e as possíveis contribuições para práticas profissionais. Trata-se de um estudo pautado no mapeamento de dados sobre o perfil e acompanhamento de egressos e das dissertações produzidas no período de 2014 a 2017, em um Mestrado Profissional no interior do estado de São Paulo. Todos os egressos referiram que a pesquisa desenvolvida no mestrado tem relação com sua atuação profissional, tanto no âmbito do ensino quanto no da gestão escolar: $34 \%$ relacionadas a instrumentos de avaliação escolar; $34 \%$ a materiais didáticos, $21 \%$ à formação de professores, e demais pesquisas envolvendo estudos sobre evasão escolar e práticas pedagógicas. A maioria considera que os resultados de suas pesquisas auxiliaram na resolução de problemas nas instituições de ensino em que atuam. Esses dados revelam egressos de Mestrado Profissional que buscaram melhorar sua formação na área da educação, na qual já atuavam ou pretendiam atuar, e que, embora com características de iniciantes no processo de pesquisa científica, os egressos desenvolveram estudos científicos relacionados às suas áreas profissionais.

Palavras-chave: Egressos. Mestrado Profissional. Formação de Professores. 


\section{INTRODUÇÃO}

A temática dessa pesquisa envolve o desafio dos Mestrados Profissionais diante do grupo de discentes, composto na sua maioria de professores atuantes em áreas diversas e distantes da área acadêmica. Principalmente por essa demanda, e pelos próprios objetivos desta modalidade de mestrado, espera-se uma formação que amplie o conhecimento e pesquisas com resultados que contribuam para a superação de práticas acadêmicas baseadas demasiadamente em aspectos teóricos. Ademais, ressaltam-se as contribuições para uma formação profissional e acadêmica que promovam melhorias nas organizações públicas e privadas para solução de problemas e construção de processos inovadores aplicáveis às práticas profissionais (BRASIL, 2017). À vista desses desafios, a indagação norteadora deste estudo reside em saber se a produção acadêmica dos egressos de mestrado profissional em educação traz contribuições para as práticas profissionais e organizacionais a que estão vinculados.

Diante do exposto, o objetivo deste estudo é relatar o perfil das pesquisas desenvolvidas em um Mestrado Profissional na área de Educação e as possíveis contribuições indicadas nessas produções acadêmicas para as práticas profissionais dos egressos.

\section{FUNDAMENTAÇÃO TEÓRICA}

Numa perspectiva interdisciplinar prevista pela diversidade de formação inicial dos alunos, os apoios teóricos serão diversos com autores voltados para a formação de professores e pesquisadores dessa recente modalidade de pós-graduação stricto sensu.

Percebe-se que a clientela de um mestrado profissional é composta por alunos com pouca experiência em realizar pesquisas, provavelmente relacionada à formação inicial com focos teóricos ou diretamente técnicos disciplinares, e distanciados de reflexões sobre a prática, conforme apontado por Nóvoa (2007), o que passa a ser um fator preocupante para os programas de mestrado (Cevallos; Passos, 2012).

Com inquietações semelhantes, Silva (2017) sinaliza a dificuldade em ter como foco de estudo formações em mestrado de natureza profissional, compreendendo que a interface universidade e escola exige interação de referenciais diversos, de saberes múltiplos que permeiam a ação profissional, e que se encontram enraizados nas identidades profissionais das diversas partes envolvidas, como o próprio pesquisador/professor, demais professores participantes, os objetos de pesquisa escolhidos e outros colaboradores.

Para Silva (2017, p.714), o mestrado profissional tem a função de favorecer a construção de saberes que possam ser aplicáveis para além da academia, "rompendo com a reprodução acrítica de teorias ou com a prática de pesquisa em função do fortalecimento ou da confirmação de teorias de referência."

Nesse sentido, verifica-se a relevância da natureza do mestrado profissional, visando, entre outros aspectos, à integração dos estudos acadêmicos com as ações dos cursistas em seus espaços de atuação profissional.

Considerando a afirmação de Nóvoa (1998) acerca da valorização intelectual e da consolidação da autonomia profissional dos docentes, o espaço de formação no referido curso de pós-graduação sinaliza a possibilidade de pesquisa e ação em uma perspectiva do mestrando pensar sobre e, ao mesmo tempo, intervir na realidade de trabalho.

Os professores não são apenas executores, mas são também criadores de instrumentos pedagógicos. Os professores não são apenas técnicos, mas são também profissionais críticos e reflexivos. Assim sendo, é preciso rejeitar as tendências que apontam no sentido de separar a concepção da execução, tendências que põem nas mãos dos professores pacotes curriculares prédesenhados prontos a serem aplicados, que procuram sobrecarregar o quotidiano dos professores com atividades que lhes retiram o tempo necessário à reflexão e à produção de práticas inovadoras (Nóvoa, 1998, p.31).

Nesse sentido, torna-se adequada a produção de pesquisas que sinalizem inquietações sobre a prática profissional dos cursistas, em um movimento de adentrar no campo de publicações acadêmicas que possam contribuir para a formação intelectual dos mestrandos, favorecendo a sua criticidade e atuação profissional. Em outras palavras, o mestrado profissional em educação constitui espaço diferenciado ao propiciar que, problemas, dificuldades, questionamentos oriundos do campo prático de atuação possam ser tomados como objeto de estudo para análise e busca de soluções fundamentadas teoricamente. Podem 
inclusive apresentar características inovadoras, conforme expressam Martins e Ribeiro (2013) ao analisarem o conceito de inovação educacional, o que implica provocar uma mudança de modo deliberado, intencional e planejado para alterar a situação vigente, visando a melhorias nas práticas correntes. A inovação tem caráter endógeno, fruto de busca intencional dos agentes envolvidos no processo educativo.

\section{PROCEDIMENTOS METODOLÓGICOS}

Trata-se de um estudo pautado no mapeamento de dados sobre o perfil e acompanhamento de 51 egressos e das dissertações produzidas no período de 2014 a 2017.

O Mestrado Profissional, objeto desta pesquisa, pertence a uma rede privada de ensino localizada em um município do interior do estado de São Paulo, tendo iniciado sua atuação em 2014, com a proposição dos seguintes objetivos gerais e específicos:

I. Desenvolver estudos em nível de pesquisa e extensão à comunidade no campo da Educação, especificamente dedicados ao ensino e gestão educacional, visando contribuir para a formação de profissionais das áreas de Educação do Brasil com destaque para o estado de São Paulo;

II. Aperfeiçoamento da qualidade dos setores educacionais da administração;

III. Capacitar recursos humanos vinculados ou com possibilidades de vinculação nos serviços de Educação, universidades e outras instituições educacionais, em questões de Educação, Ensino e Gestão Educacional, considerando a necessidade de estimular a formação de mestres profissionais habilitados para desenvolver atividades e trabalhos técnico-científicos em temas de interesse de qualidade da área da educação. (Brasil, 2013).

Com base nos objetivos propostos, as atividades de ensino e pesquisa do curso foram organizadas em torno de duas linhas de pesquisa: processos de ensino e gestão educacional.

A duração do curso é de 2 (dois) anos, com a possibilidade de prorrogação por mais 6 (seis) meses e tem atraído, principalmente, professores e gestores da Educação provenientes das cidades da região e até de outros estados (Amazonas, Minas Gerais, Recife, entre outros), apresentando um fluxo considerável.

Os procedimentos metodológicos utilizados para a obtenção de dados das duas fontes documentais investigadas - perfil dos egressos e produção de pesquisas- incidiram na leitura, sistematização e categorização de documentos apresentados na sequência. Para a especificação do perfil dos alunos foram utilizados os dados básicos fornecidos no ato da matrícula e nos formulários de acompanhamento dos egressos. Para dados sobre os resultados das pesquisas realizadas foram considerados os trabalhos de conclusão do curso de mestrado disponibilizados no site da universidade e os dados sobre a produção acadêmica registrada nos currículos Lattes dos alunos egressos. A análise de tais documentos pautou-se nos temas das pesquisas e nos resultados obtidos e suas possíveis aplicações práticas, bem como no envolvimento dos alunos na divulgação dos mesmos em meio científico ou em ações práticas nas escolas.

\section{RESULTADOS E DISCUSSÃO}

0 perfil dos 51 egressos, até o final de 2017, revela alunos atuantes em níveis diversos de ensino como docentes ou nas equipes de gestores, com predominância no ensino técnico, mas, abrangendo da educação básica até o ensino superior, graduados em diferentes áreas do conhecimento. Entre eles destacamos: professores e coordenadores de Instituições de Ensino Técnico; professores e gestores do Ensino Infantil, Fundamental, Médio, Educação de Jovens e Adultos, e do Ensino Superior. Interessante notar a diversidade na origem de suas graduações: pedagogia, direito, geografia, filosofia, engenharia, psicologia, artes plásticas, educação física, administração, letras, ciências físicas e biológicas, ciências da computação, história, tecnologia de processamentos de dados, física, comunicação social, ciências econômicas e farmácia e bioquímica. Esses dados revelam a diversidade de uma clientela que buscou o Programa de Mestrado para, sobretudo, melhorar sua formação na área da educação, na qual já atuava ou pretendia atuar.

É preciso enfatizar que, considerando a forma de implementação da Proposta e o acompanhamento cuidadoso dos alunos tanto na realização das disciplinas obrigatórias e optativas, na orientação dos projetos e na realização das Atividades Programadas de Pesquisa, e considerando as características de 
iniciantes no processo de pesquisa científica, os egressos desenvolveram estudos científicos relacionados às suas áreas profissionais, defendendo-os em média após 23 meses a partir da data da matrícula.

Com base em um mapeamento dos 51 trabalhos de conclusão de curso defendidos até dezembro de 2017, foi possível identificar quatro categorias atendendo às duas linhas de pesquisa do Programa: Processos de Ensino e Gestão Educacional, expostas no Gráfico 1:

Gráfico 1: Mapeamento Pesquisas 2014-2017

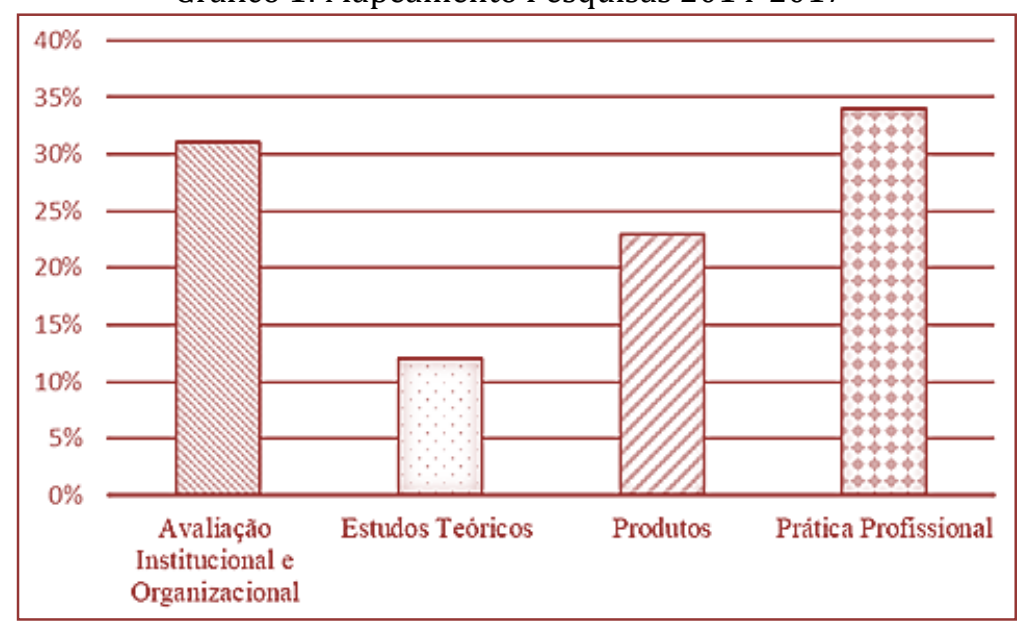

Fonte: dados organizados pelas autoras (2018)

Pesquisas sobre Avaliação Institucional e Organizacional abrangendo focos diversificados referentes ao âmbito institucional e organizacional envolvendo escolas, gestores, secretarias de educação, sobre a relação família e escola e desempenho de alunos, evasão escolar, políticas avaliativas, e avaliações de natureza pedagógica de alunos e práticas docentes;

Estudos Teóricos distribuídos entre revisões (bibliográfica e documental) sobre alfabetização e práticas de gestão, estudos de caso sobre práticas pedagógicas, e estudo de políticas públicas para ensino médio e técnico;

Pesquisas com focos no desenvolvimento de Produtos, tais como elaboração de instrumentos e materiais didáticos para prática pedagógica, e resultados que colaboram para propostas ou sugestões para formação de professores (inicial, continuada, em serviço) e gestores;

Pesquisa sobre a Prática Profissional de docentes e gestores, bem como revisões curriculares, com resultados aplicáveis à prática do egresso em sala de aula ou na sua instituição de ensino, passíveis de serem multiplicadas por outros agentes.

Observa-se que as categorias Produtos e Prática Profissional juntas configuraram a maioria das investigações e estão em consonância com as expectativas de pesquisas para um mestrado profissional, ambas relacionadas à ação docente, seja em sala de aula ou em cargos de gestão. Deve-se ressaltar que as duas outras categorias Avaliação Institucional e Organizacional e Estudo Teórico se aproximam da escola e das ações do professor ou gestor por tratarem de estudos analisando instrumentos de avaliação escolar, políticas públicas, prováveis relações com a organização das instituições e teorias educacionais. É possível considerar que os dados obtidos têm aplicabilidade à prática profissional e a processos de formação prática de professores em níveis variados de ensino.

Esses dados objetivos foram corroborados pela percepção dos egressos sobre a relevância de suas pesquisas relacionada à prática profissional, quando $24 \%$ deles responderam ao protocolo de acompanhamento de egressos, sobre a relação da pesquisa desenvolvida com as suas atuações profissionais: $34 \%$ a consideraram relacionada a instrumentos de avaliação escolar cujos dados são aplicáveis a estudos sobre os projetos políticos pedagógicos das instituições; $34 \%$, a materiais didáticos aplicáveis à prática em sala de aula, e $21 \%$, à formação de professores.

Mesmo sem experiência acadêmica, 62,5\% procuram divulgar suas pesquisas em meio científico, prevalecendo a participação em congressos, seguida por artigos em revistas científicas, capítulos de livro, palestras e materiais didáticos institucionais. 
É notável, ao verificar o currículo Lattes dos egressos que, a partir do momento em que ingressam no Programa de Mestrado, há um aumento significativo da participação em atividades acadêmicas pelos cursistas. Após a conquista do título de mestre/a, verifica-se que há egressos que continuam realizando as referidas atividades, revelando que a inserção em um curso de pós-graduação stricto sensu favorece o envolvimento dos cursistas com o universo acadêmico, em um movimento de partilha de pesquisas em eventos e textos científicos, entre outras vivências.

As produções registradas pelos egressos em seus currículos Lattes indicam algumas ações vinculadas ao universo acadêmico. Entre elas, encontram-se trabalhos e resumos publicados em anais de eventos, autoria de capítulos e livros na íntegra, artigos publicados em periódicos, apresentação de trabalhos em eventos.

De fato, a inserção em curso de pós-graduação - mestrado e doutorado - favorece esse movimento acadêmico e os motivos para a realização das atividades são variados, entre eles, a exigência do cumprimento de créditos em atividades de pesquisa. Ainda que se possa afirmar que essa exigência seja um fator em destaque, não são raras afirmações dos cursistas e egressos sobre as experiências positivas que o Programa de Mestrado possibilita, entre elas, participação em eventos e publicações. No decorrer das aulas oferecidas pelo Programa e em situações de orientação, algumas falas são recorrentes, como: "Estou muito motivado/a com a possibilidade de participação em eventos." "Pretendo continuar realizando atividades acadêmicas e científicas após o curso de Mestrado."

Embora os objetivos de um Mestrado Profissional não sejam específicos para encaminhar os seus alunos para cursos de doutorado, é importante salientar que a formação obtida no Programa motivou alguns deles a prosseguirem na carreira de pesquisadores, pois, $8 \%$ dos egressos encontram-se atualmente cursando Doutorado na área da Educação em universidades públicas.

\section{CONSIDERAÇÕES FINAIS}

A necessidade de entender os desafios enfrentados pelos mestrados profissionais na formação de pesquisadores atuantes em áreas muito diversas e com pouca experiência em pesquisa acadêmica motivou a realização deste estudo por um grupo de professores de um programa de mestrado, que iniciou seus trabalhos em 2014, no sentido de avaliar os resultados obtidos em tão curto espaço de tempo bem como enfrentar os desafios que estão colocados para os próximos anos.

Observa-se a importância da análise aqui feita de como as produções acadêmicas estão sendo desenvolvidas com intuito de atender aos objetivos propostos pelos mestrados profissionais. Assim, o presente trabalho revela positividade ao constatar que a maior parte dos estudos científicos desenvolvidos atende às expectativas de trabalhos acadêmicos propostos para um mestrado profissional, visto que estão vinculadas ao trabalho docente tanto em sala de aula quanto em funções de gestão.

Ainda, é notável, pelas respostas expressas no protocolo de acompanhamento dos egressos, que os aproximadamente $50 \%$ que preencheram o formulário valorizam a sua inserção no universo científico para além da escrita da dissertação de mestrado, uma vez que revelaram a participação em atividades acadêmicas, como publicações das pesquisas desenvolvidas, apresentação de trabalhos em eventos, entre outras ações. Isso pode ser verificado, também, ao se analisar o currículo Lattes dos egressos. Pelos registros descritos e nas conversas informais, fica visível o interesse que a maioria dos egressos expressou em relação ao universo acadêmico, entusiasmando-se, muitas vezes, com as possibilidades de vivenciarem as atividades promovidas pela academia, em especial, na área da educação.

Tratando-se de uma modalidade recente da pós-graduação, verifica-se a necessidade de compreensão do perfil dos mestrandos que optam por cursá-la, visando compreender seus interesses e anseios. Pelo exposto, há um conjunto de atividades realizadas pelos egressos que favorecem a sua formação acadêmica e suas ações no dia a dia da profissão, contribuindo também para divulgação e partilha de trabalhos sobre a prática profissional. 


\section{REFERÊNCIAS}

[1] Brasil, Ministério da Educação. Coordenação de Aperfeiçoamento de Pessoal de Nível Superior (Capes). Apresentação de propostas para cursos novos (APCN) - Mestrado Profissional em Processos de Ensino, Gestão e Inovação, 2013.

[2] Brasil, Ministério da Educação. Portaria no 389, de 23 de março de 2017. Diário Oficial da União. Seção 1. p.61. Disponível em: https://capes.gov.br/images/stories/download/legislacao/24032017- Portaria-n0- 389-de-23de-março-de-2018. Acesso em: 20 mar. 2018.

[3] Cevallos, I.; Passos, L. F. O mestrado profissional e a pesquisa do professor. Rev. Diálogo Educ., Curitiba, v. 12, n. 37, p. 803-822, set./ dez. 2012.

[4] Martins, R. X.; Ribeiro, C. M. Mestrado profissional em Educação e inovação na prática docente. RBPG, Brasília, v. 10, n. 20, p. 423 - 446, jul. 2013.

[5] Nóvoa, A. Nada substitui o bom professor. In: FARO, J. S.; GUTIERRE, Priscilla (Org.). Desafios do trabalho do professor no mundo contemporâneo (livreto). São Paulo: SINPRO-SP, 2007.

[6] Nóvoa, A. Relação escola - sociedade: "novas respostas para um velho problema”. In: SERVINO, R. V. et al. (Org.). Formação de professores. São Paulo: Fundação Editora UNESP, 1998.

[7] Silva, W. R. Formação sustentável do professor no mestrado profissional. Revista Brasileira de Educação. v. 22, n. 70, p.708-731, jul./set. 2017. 


\section{Capítulo 3}

Concepção de uma turma de licenciandos em química sobre as metodologias de ensino e suas contribuições na formação inicial

Samila Jacinto

Gean Aparecido Zapateiro

Zenaide de Fátima Dante Correia Rocha

Marcia Camilo Figueiredo

Resumo: Num cenário em que nos cursos de licenciatura tem se priorizado a formação técnica e científica e a formação pedagógica é vista em segundo plano, as tentativas de reestruturação em virtude das pesquisas e discussões realizadas face à formação de professores, principalmente nas décadas de 80 e 90, na prática atual pouco mudou. Diante o exposto, esta pesquisa buscou responder a seguinte questão: Como os licenciandos compreendem sua formação inicial? Para isso foi entrevistada uma turma de licenciandos em Química que cursavam as disciplinas de Estágio Supervisionado III e Metodologia e Prática no Ensino de Química III, em uma Universidade Federal de Londrina - PR. 0 objetivo foi investigar como um grupo de licenciandos concebem as metodologias de ensino de Química e sua importância na formação inicial. A análise das falas significativas à questão investigada revelam que os licenciandos entendem que as metodologias de ensino são importantes para que o docente rompa com a concepção de ensino tradicional em que os professores detentores do conhecimento transferem os conceitos aos alunos e estes tendem a agirem passivamente frente ao processo de ensino e aprendizagem, não despertando o interesse destes pela ciência Química e dificultando a compreensão dos conceitos. Os resultados sinalizam para a necessidade de se repensar os cursos de formação inicial, priorizando a integração do vasto campo que abarca os conhecimentos científicos e que estimule esses profissionais a refletirem sobre a sua prática docente.

Palavras-chave: Formação inicial, Ensino de Química, Metodologias de ensino. 


\section{INTRODUÇ̃̃OO}

Historicamente, no Brasil, os cursos de licenciatura são inferiorizados pela sociedade e marginalizados, até mesmo dentro das próprias instituições de ensino superior em comparação aos cursos ditos de elite como bacharelado, engenharias, medicina e direito. A remoção de alguns direitos desta classe de trabalhadores, a falta de investimento público na educação, o sucateamento das escolas públicas, baixa remuneração e a má qualidade do ensino básico têm contribuído para a desvalorização da figura do professor e a consequente redução de egressos nos cursos de formação inicial.

Num cenário em que nos cursos de licenciatura tem sido priorizada a formação técnica e científica em detrimento da formação pedagógica, que é vista em segundo plano, as tentativas de reestruturação em virtude dos resultados de pesquisas e discussões realizadas sobre o tema, principalmente nas décadas de 80 e 90 , na prática pouco mudou.

Os reflexos da deficiente formação inicial dos professores na educação básica não são os melhores, o último levantamento realizado pelo Programa Internacional de Avaliação dos Estudantes - PISA indicou o baixo desempenho dos alunos brasileiros nas áreas de ciências, leitura e matemática, no quadro geral a pontuação nestas respectivas áreas foi inferior à média dos demais países participantes da Organização para Cooperação e Desenvolvimento Econômico - OCDE (Brasil, 2015).

Esta informação corrobora com as críticas elencadas pelos vários pesquisadores frente às limitações dos cursos de licenciatura, que segundo eles os profissionais da educação não estão sendo devidamente preparados para atuarem no Ensino básico (Pimenta, 1998; Carvalho e Gil-Perez, 2011; Imbenón, 2009).

Os cursos de formação inicial possuem uma organização comum com duração de 4 anos, nos primeiros anos são apresentados aos licenciandos as disciplinas específicas de sua área com uma carga horária elevada e algumas disciplinas de didática, no penúltimo ano os licenciandos cursam as disciplinas de metodologias de ensino e estabelecem o primeiro contato com o ambiente escolar por meio dos estágios supervisionados, contudo apenas no último ano de estágio os licenciandos desenvolvem suas atividades de regência e assumem o papel de professor em sala de aula.

Esta carência no que se refere à preparação prática se deve a fragmentação que há entre o estágio supervisionado e as disciplinas específicas e pedagógicas, impedindo que o futuro professor tenha uma formação crítica reduzindo sua ação a uma mera repetição metodológica, ou seja, este estará capacitado para reproduzir o que observou das práticas de outros professores (Pimenta; Lima, 2006).

Em contrapartida, entende-se que este profissional precisa aprender a refletir criteriosamente sobre sua prática no primeiro momento de sua formação, desenvolvendo assim suas habilidades e competências no que diz respeito a ensinar. 0 parecer CNE/CES n ${ }^{\circ} 1.303 / 2001$ das Diretrizes Curriculares Nacionais para os Cursos de Química, estabelecem que os futuros professores de Química devem ter:

“Formação generalista, mas sólida e abrangente em conteúdo dos diversos campos da Química, preparação adequada à aplicação pedagógica do conhecimento e experiências de Química e de áreas afins na atuação profissional como educador na educação fundamental e média" (Brasil, 2001, p. 4).

Sobre a formação de professores para o Ensino de Química encontram-se na literatura relevantes estudos de Carvalho e Gil-Perez, (2011), Shön (1995) e Maldaner (2006) que colaboram para a construção de novos conhecimentos pedagógicos e fomentam melhorias no processo de ensino e de aprendizagem.

Diante o exposto, buscamos responder a seguinte questão: Como os licenciandos compreendem sua formação inicial? Com a intenção de responder esse problema, entrevistamos uma turma de licenciandos em química que cursavam as disciplinas de Estágio Supervisionado III e Metodologia e Prática no Ensino de Química III, em uma Universidade Federal de Londrina - PR.

Esta pesquisa teve por objetivo investigar como um grupo de licenciandos concebem as metodologias de ensino de Química e sua importância na formação inicial.

\section{PROCEDIMENTOS METODOLÓGICOS}

Para o desenvolvimento desta pesquisa adotamos a abordagem qualitativa de natureza aplicada e classificada em descritiva conforme Lüdke e André (1986). 
A proposta de investigação sobre o tema surgiu no contexto de um trabalho de dissertação do curso de Pós-Graduação na linha de ensino de ciências da natureza. A pesquisa foi desenvolvida com 6 graduandos do curso de Licenciatura em Química de uma Universidade Federal de Londrina - PR, durante a disciplina de Metodologia e Prática no Ensino de Química III, integrada ao Estágio Supervisionado III, ocorrida no primeiro semestre de 2018.

Realizou-se uma entrevista do tipo semiestruturada como técnica de coleta de dados, os diálogos foram transcritos conforme a técnica da análise das falas significativas, uma vez que "representam uma expressão de um pensamento, de um saber, quando se parte do princípio de que em qualquer pessoa humana há um crescente conhecimento vivenciado e acumulado sob a forma de uma integração cultural de saberes" (Brandão, 2003, p. 142).

Para manter a identidade dos sujeitos em sigilo, os licenciandos participantes da pesquisa foram identificados durante todo o estudo pelas siglas L1, L2, L3, L4 e L5.

As questões norteadoras que compuseram a entrevista estão apresentadas no Quadro 01.

Quadro 01: Questões que compõe o questionário utilizado na pesquisa.

\begin{tabular}{|c|l|l|}
\hline Item & \multicolumn{1}{|c|}{ Categoria } & \multicolumn{2}{c|}{ Pergunta } \\
\hline 1 & Identidade do sujeito & $\begin{array}{l}\text { Me fale mais sobre você, como chegou aqui? Como você veio fazer Licenciatura } \\
\text { em Química? Conta essa história para mim. }\end{array}$ \\
\hline 2 & $\begin{array}{l}\text { Metodologias de } \\
\text { ensino }\end{array}$ & $\begin{array}{l}\text { Você conhece metodologias de ensino de Química? Quais? Quais metodologias } \\
\text { foram apresentadas a você ao longo da graduação? Existem outras que você } \\
\text { julga importante conhecer? }\end{array}$ \\
\hline 3 & $\begin{array}{l}\text { Formação e prática } \\
\text { docente }\end{array}$ & $\begin{array}{l}\text { Sobre a sua formação inicial, você acredita estar preparado para atuar na } \\
\text { educação básica? }\end{array}$ \\
\hline
\end{tabular}

Fonte: Os autores.

Para a análise dos dados obtidos foi feita uma leitura minuciosa das respostas audiogravadas, a fim de transcrever as falas significativas dos licenciandos face às três categorias elencadas.

\section{RESULTADOS E DISCUSSÕES}

Ao analisarmos as falas significativas transcritas sobre a identidade dos licenciandos percebemos que há um caráter comum entre elas, visto que se repetiu no discurso de todos os sujeitos indícios similares sobre a escolha do curso, um exemplo disso foi que nenhum deles ingressou pelo desejo de lecionar conforme descrito pelo participante L1:

[...] então pra me manter aqui eu tinha que trabalhar e bacharel é integral aí eu não conseguia aí foi onde surgiu através de um jornal ei fiquei sabendo da existência da utf e vi que tinha licenciatura[...]. (L1).

Outros licenciandos não pensavam sequer em se graduar em Química, conforme as falas de L5 e L6:

[...] eu comecei o curso de licenciatura em química em 2015, não sendo minha primeira opção minha primeira opção lá atrás foi medicina algumas frustrações me levou a fazer o enem e no primeiro enem fui selecionado aqui [...]. (L5).

[...] eu prestava engenharia civil na verdade eu sou do interior de São Paulo né então engenharia lá é bem forte principalmente na Unesp essas coisas e era a faculdade que eu prestava e aí eu acabei não passando na Unesp principalmente que era meu foco assim mais voltado, por pouco claro aí eu acabei caindo aqui porque meu irmão já fazia [...]. (L6).

Desse modo, é preocupante pensar que estes futuros professores ingressaram no curso de Licenciatura em Química pelos vários motivos citados e que divergem do esperado para o profissional docente da disciplina de Química na educação básica, L1 justificou que precisava trabalhar, sendo assim, optar pelo bacharelado seria inviável. Já L5 e L6 tinham como expectativa atuar nas áreas de Medicina e Engenharia Civil. Este perfil se repete em outros cursos de Licenciatura em Química no Brasil, assim como apresentado nas pesquisas de Sá e Santos (2017); Fadigas (2016) e Silva e Oliveira (2008). 
Sobre as metodologias no ensino de química é possível identificar na fala dos licenciandos L2, L3 e L5 uma preocupação em apresentar os conteúdos de modo contextualizado, aguçando a curiosidade dos alunos por meio de atividades experimentais.

[...] eu acho que assim na realidade o que falta mesmo é a gente tentar aproximar a química da realidade do aluno eu acho que as vezes realmente a gente fica só na teoria teoria, eles odeiam química pela teoria não adianta não importa o que você faça pode ser um professor que ensina bem tudo eles até gostam, mas geralmente o aluno que presta mais atenção e se dedica é aquele que pretende fazer alguma coisa que ele vai precisar da química os que não vão fazer nada não tão nem aí. [...]. (L2).

[...] a metodologia ajuda né, você está traçando uma rota com intuito de promover uma aprendizagem mais significativa para o aluno, o que eu gosto pelo menos pelo que tenho visto por aqui é a ideia de você aprofundar e contextualizar a ciência, você só não vem e traz ela do jeito que está no livro tradicional de química com um monte de decoreba e um monte de macete, você aproxima com a realidade do aluno [...]. (L3).

[...] metodologias eu vejo assim que essa parte final no curso eu gostei bastante da parte de investigação essa parte me tocou bastante, apesar de não estar fazendo o TCC nessa parte de educação foi muito importante eu ver essa opção de metodologia que você chega fazendo questionamento para os alunos fazendo perguntas né e não diretamente do conteúdo em si, e então essa metodologia de investigação foi a que eu mais me situei durante a formação [...]. (L5).

Os sujeitos L2 e L3 entendem que as metodologias de ensino são importantes para que o docente rompa com a concepção de ensino tradicional, em que os professores detentores do conhecimento transferem os conceitos aos alunos, que por sua vez agem passivamente frente ao processo de ensino e aprendizagem, não despertando o interesse destes pela ciência Química e dificultando a compreensão dos conceitos.

L1 aponta a importância de saber escolher a metodologia adequada no momento de elaborar o planejamento de ensino.

[...] em metodologias sem dúvidas ajuda muito tanto na hora de planejar uma aula quanto na hora de aplicar porque tem uma organização, um método torna a aula um pouco mais planejada e até mesmo dinâmica em alguns casos. [...]. (L1).

0 professor ao organizar as atividades a serem desenvolvidas em sala de aula precisa se atentar aos objetivos educacionais e quais ações irá realizar para atingi-lo (Charlot, 2013).

Os licenciandos L2 e L4 revelaram apresentar dificuldades no momento de aplicar as metodologias de ensino, como pode ser constatado nas falas de L2 e L4:

[...] uma metodologia que eu tenho estudado bastante e eu tenho gostado é a do Paulo freire que realmente trabalha a pedagogia dialógica é a que eu mais tenho gostado de estudar e que eu gostaria de aplicar. Mas, também é um desafio não é fácil e em relação também a hora de execução da aula mesmo quando a gente fala de metodologia tradicional tecnicista e tudo mais é muito difícil as vezes fugir totalmente do tradicional, o tradicional faz parte até porque a gente uma sequência do livro didático que é baseado no ensino tradicional que é difícil fugir daquilo, mas eu acho que tem mecanismos pra gente fugir daquilo tentar fugir um pouco mas tentar fazer disso tudo que a gente usa fazer parte do ensino [...]. (L2).

[...] difícil essa pergunta, elas estão lá agora por exemplo se eu ver a aula de algum professor eu consigo dizer esse professor usa a metodologia tal. Agora se fosse para aplicar seria mais difícil tipo usa essa metodologia para dar uma aula acho que fica mais complicado, por exemplo eu tô fazendo a disciplina de EJA e lá eu tenho que dar uma aula com a metodologia dialética de Freire daí fica mais complicado [...]. (L4).

Neste contexto, entendemos que essa dificuldade é resultado da desarticulação entre teoria e prática. De acordo com Ferraz (2000) a teoria é um mecanismo que auxilia a apreender o real, contudo é 
experenciando na prática que surgem os problemas e quando encarados com seriedade levam ao crescimento profissional.

Sobre a formação inicial e prática docente, apenas L4 se sente preparado para atuar na educação básica:

[...] até um tempo atrás não, mas com a disciplina de estágio ajudou bastante a preparar como se portar lá na frente isso aí tá ok, mas quanto a confiança mesmo só com a experiência [...]. (L4).

Contudo, os demais licenciandos afirmaram não estarem preparados para aturem na educação básica por diversos motivos, entre os quais ficou evidente a dificuldade de se relacionar com os alunos e realizar a transposição dos conteúdos científicos a eles, conforme relataram L1, e L2:

[...] eu acho que não estou preparada, em questão de conhecimento sim porque isso é estudando e.... em questão de lidar com os alunos eu acho que não estou preparada e é isso que as vezes pega um pouco na questão de na regência pegando em especifico a regência que é o contato que a gente tem aqui na faculdade com os alunos né eu acho que essa questão de lidar com eles que falta um pouco [...]. (L1).

[...] cem por cento não, até porque a gente começa fazer o estágio de regência muito tarde muito tarde, e aí a gente se depara com isso e aí você vê o quanto você ainda tem que correr pra tentar ter experiência e saber lidar com aquilo ali então a gente percebe por que as vezes você vai e faz uma prova aqui e você vai super bem você sabe o conteúdo, mas o passar esse conteúdo e saber lidar com essas situações que é o difícil e a gente tem muita matéria especifica o curso todo e no final a gente vai trabalhar mais essas questões [...]. (L2).

Além disso, L2 ainda mencionou que o curso prioriza as disciplinas específicas e no final apenas são discutidas essas questões nas disciplinas integradas ao estágio supervisionado. Acreditamos que esta percepção contribui para o entendimento de que todas as disciplinas ministradas, sejam elas específicas ou pedagógicas, devem estar articuladas de modo a capacitar os licenciandos para a docência.

\section{CONSIDERAÇÕES FINAIS}

Diante da desvalorização da figura do professor e a consequente redução de egressos nos cursos de formação inicial, surgiu o interesse em investigar como um grupo de licenciandos concebem as metodologias de ensino de Química e sua importância na formação inicial.

A análise das falas significativas revela que os licenciandos entendem que as metodologias de ensino são importantes para que o docente rompa com a concepção de ensino tradicional, em que os professores detentores do conhecimento transferem os conceitos aos alunos e estes agem passivamente frente ao processo de ensino e aprendizagem, não despertando o interesse destes pela ciência Química e dificultando a compreensão dos conceitos.

Os resultados sinalizam para a necessidade de se repensar os cursos de formação inicial, priorizando a integração do vasto campo que abarca os conhecimentos científicos, sejam estes específicos da área de química ou das ciências da educação no sentido de estimular e potencializar a esses profissionais refletirem sobre a prática docente (Alarcão, 2003).

\section{REFERÊNCIAS}

[1] Alarcão, I. Professores Reflexivos em Uma Escola Reflexiva. São Paulo: Editora Cortez. 2003.

[2] Brasil. Parecer CNE/CES 1.303/2001, de 06 de novembro de 2001. Estabelece as Diretrizes Curriculares Nacionais para os Cursos de Química. 2001.

[3] Brasil. Instituto Nacional de Estudos e Pesquisas Educacionais Anísio Teixeira (INEP). Resumo de Resultados Nacionais do PISA 2015. São Paulo: Fundação Santillana, 2015. Disponível em:

<http://download.inep.gov.br/acoes_internacionais/pisa/resultados/2015/pisa_2015_brazil_prt.pdf > Acesso em: 28 out. 2018.

[4] Brandão, C. R. A pergunta a várias mãos: a experiência da pesquisa no trabalho do educador. São Paulo: Cortez, 2003. 
[5] Carvalho, A. M. P. e GIL -PÉREZ, D. Formação de professores de ciências: tendências e inovações. São Paulo: Cortez, 2011.

[6] Charlot, Bernard. Da relação com o saber às práticas educativas. Edição revista e ampliada. São Paulo: Cortez, 2013.

[7] Fadigas, J. C. Perfil dos Estudantes de Licenciatura em Química da Universidade Federal da Bahia. In: XVIII Encontro Nacional de Ensino de Química (XVIII ENEQ). Florianópolis, 2016. Disponível em: http://www.eneq2016.ufsc.br/anais/resumos/R0251-1.pdf. Acesso em: 30/07/2018.

[8] Ferraz, L. Formação e Profissão docente: a postura investigativa e o olhar questionador na atuação dos professores. Movimento. Revista da Faculdade de Educação da UFF. Profissão docente: teoria e prática. DP\&A, noㅡ 2, setembro de 2000.

[9] Imbernón, Francisco. Formação permanente do professorado: novas tendências. São Paulo: Cortez, 2009.

[10] Lüdke, M; André, M. E. A. Pesquisa em educação: abordagens qualitativas. 5. ed. São Paulo: EPU, 1986.

[11] Maldaner, O. A. A formação inicial e continuada de professores de química: professores/pesquisadores. Ijuí: Unijuí, 2006. (Coleção educação em química).

[12] Pimenta, S. G. "Formação de professores: saberes da docência e identidade do professor". In: Fazenda, I. (Org.). Didática e interdisciplinaridade. Campinas: Editora Papirus, p. 161-178, 1998.

[13] Pimenta, S. G.; LIMA, M. S. L. Estágio e docência: diferentes concepções. Revista Poíesis, São Paulo, v.3, n.3 e 4, p. 5-24. 2006.

[14] Sá, C. S. da S.; SANTOS, W. L. P dos. Constituição de identidades em um curso de licenciatura em química. Revista Brasileira de Educação v. 22 n. 69 abr.-jun. 2017. Disponível em: http://www.scielo.br/pdf/rbedu/v22n69/1413-2478-rbedu-22-69-0315.pdf. Acesso em: 30. Jul. 2018.

[15] Schön, D. A. Formar professores como profissionais reflexivos. In: NÓVOA, A. (Coord.). Os professores e a sua formação. 2 ed. Lisboa: Dom Quixote, 1995.

[16] Silva, C. S.; OLIVEIRA, L. A. A. Análise de uma turma de licenciandos em Química ao ingressar e ao se formar no curso: perfil, expectativas, influências e críticas. In: XIV Encontro Nacional de Ensino de Química, 2008, Curitiba. Anais... Curitiba: UFPR, 2008. 


\section{Capítulo 4}

\section{Utilização da sala de aula invertida em cursos de graduação em engenharia}

Ricardo Luiz Perez Teixeira

Cynthia Helena Soares Bouças Teixeira

Priscilla Chantal Duarte Silva

Resumo: Este trabalho, publicado recentemente com o mesmo título na revista The Brazilian Journal of Development e no evento XLVII Congresso Brasileiro de Educação em Engenharia, aborda os resultados de dois semestres consecutivos da aprendizagem e do desempenho de discentes brasileiros em engenharia quando da utilização da sala de aula invertida. Encadear ao processo de ensino/aprendizagem conteúdos práticos e teóricos constitui um desafio à educação em engenharia e ciências. Em princípio, esse desafio implica em novos instrumentos, atitudes e posturas nas práticas de ensino. 0 modelo de sala de aula invertida, como prática de ensino, apresenta-se como um instrumento para fomentar a participação efetiva do discente no aprendizado, pois este tem acesso ao conteúdo teórico prévio por meio de recursos e mídias digitais diversas, sempre norteado pelo facilitador docente. Neste processo, o discente, parte interlocutora do processo, tem facilitado o aprendizado e, assim, possibilita ao docente, facilitador do aprendizado, auxiliar assertivamente na aprendizagem. Neste estudo, apresentam-se os resultados da prática ensino de metodologias ativas de aprendizagem baseada em sala de aula invertida, flipped classroom, em um curso de Engenharia no Brasil. 0 objetivo da aplicação da sala invertida em educação em Engenharia, é se melhorar o rendimento acadêmico discente nas disciplinas específicas do curso de Engenharia, no intuito de fomentar a motivação e correlacionar prática e teoria, mudando o perfil do processo de ensino para o de aprendizagem ativa. 0 método utilizado nesta pesquisa é a PesquisaAção, de base semiquantitativa de abordagem de problemas orientada para a ação, em que os sujeitos não apenas pesquisam os temas buscando na ciência as possíveis soluções, mas também atuam como agentes. Os resultados semiquantitativos obtidos indicaram um bom retorno no aprendizado e desempenho discentes com a utilização de aula invertida.

Palavras chave: Aula invertida, Ensino superior, Metodologias ativas, Pesquisa-ação. 


\section{INTRODUÇÃO}

Este trabalho, publicado recentemente com o mesmo título na revista The Brazilian Journal of Development e no evento XLVII Congresso Brasileiro de Educação em Engenharia, aborda os resultados de dois semestres consecutivos da aprendizagem e do desempenho de discentes brasileiros em engenharia quando da utilização da sala de aula invertida (Teixeira et al., 2019). Deste modo, esse estudo apresenta inicialmente uma breve revisão bibliográfica e alguns resultados experimentais que podem servir como ponto de partida para futuras análises empíricas ou teorizações sobre o tema a utilização de aula invertida para engenharia.

A sala de aula invertida, constitui-se de uma modalidade de ensino híbrido (blended learning) com o acréscimo das experiências de e-learning (electronic learning) de ensino a distância. Esta modalidade de ensino possibilita o auto-aprendizado e o um engajamento do discente no aprendizado, além de possibilitar uma abordagem pedagógica em um ambiente de aprendizagem dinâmico e interativo, no qual o docente facilitador guia os discentes na aplicação dos conceitos e conhecimentos (ARNOLD-GARZA, 2014; KARLSSON; JANSON, 2016). O docente facilitador, na sala de aula invertida, media e orienta a dinâmica e a prática das atividades necessárias ao aprendizado, bem como o retorno (feedback) de acordo com o conteúdo apresentado previamente ao discente (KARLSSON; JANSON, 2016). O conteúdo, conhecimentos e atividades disponibilizados previamente em módulos pelo docente, antes de cada módulo e aula proposta, permite que haja discussões acerca de determinado tema ou tópico, o que conduz a uma melhor aprendizagem, nas quais não há oportunidade de se focar na significação, ressignificação e assimilação dos conhecimentos por parte discente (ARNOLD-GARZA, 2014).

A sala de aula invertida é uma forma de aprendizagem ativa, que dá oportunidade de melhor uso do período em sala de aula (KARLSSON; JANSON, 2016). Este tempo otimizado (período) em sala de aula pode permitir a introdução de elementos ativos facilitadores nos módulos para a retenção do aprendizado, tais como as metodologias ativas de: Project-Based Learning (PBL), Team-Based Learning (TBL), Problematização, dentre outros.

Tabela 1 - Os quatro pilares da Sala de Aula Invertida

Flexible: ser flexível e favorecer o uso de diferentes modos de ensino/aprendizagem; Organizar o espaço fisico, de modo a facilitar o trabalho em grupo; o professor deve compreender que estudantes aprendem em tempos diferentes, e assim acomodar estas diferenças na medida do possivel, durante as atividades realizadas no momento presencial.

Learning: nutrir a cultura de aprendizagem. 0 professor não deve ser mais a fonte primária e única da aprendizagem. 0 aprendizado deve L estar centrado no estudante e na sua relação com os pares (peerlearning). 0 trabalho em sala de aula deve favorecer atividades que aprofundem e deem significado ao que está sendo aprendido.

Intentional teaching actions: o professor deve ter intencionalidade naquilo que faz e propõe aos estudantes. As metas devem estar sempre relacionadas aos objetivos de aprendizagem esperados, ao longo e após conclusão do curso/disciplina; o professor deve determinar o que deverá ser ensinado/aprendido e quais os recursos necessários para que isto aconteça; Planejamento é fundamental, assim como contextualizar o que está sendo aprendido!

Professional educator: os professores devem avaliar e prover feedback regular aos estudantes; devem refletir sobre a sua prática; devem aceitar uma certa "desordem controlada" na sala de aula, enquanto os estudantes aprendem uns com os outros nas discussões e resolução das tarefas/problemas propostos; apesar de ter menos visibilidade na sala de aula invertida, o professor continua tendo um papel central no processo de ensino e aprendizagem.
Estabeleço uma agenda que favoreça interação e reflexão por parte dos estudantes?

Observo e acompanho continuamente estudantes para ajudá-los a fazerem ajustes, na medida do necessário?

Ofereço aos estudantes diferentes oportunidades de aprender 0 conteúdo?

Ofereço ao estudante oportunidades de estar no centro do próprio aprendizado, engajando- $0 \mathrm{em}$ atividades relevantes e significativas para a sua aprendizagem?

Deixo estas atividades continuamente acessiveis a todos os estudantes, sempre oferecendo feedback?

Priorizo conceitos que foram apresentados na aula gravada para serem discutidos no presencial pelos estudantes?

Crio e atualizo videoaulas relevantes e de boa qualidade para os estudantes?

Preparo material didático diferenciado e capaz de alcançar todos os estudantes?

Fico disponível para os estudantes (individual, em grupos) na medida em que é necessário?

Faço avaliação formativa e dou feedback regular aos estudantes para informá-los sobre como poderão melhorar no futuro?

Colaboro e reflito com outros educadores, assumindo a responsabilidade por revisar e melhorar minha prática docente? 
Os quatro pilares fundamentais da aula invertida, apresentados na Tabela, propostos pela comunidade Flipped Learning Network, definidos por sua sigla FLIP (JENKINS et al, 2017), constituem aspectos centrais da estratégia para verificação da adequação da técnica de aprendizagem (BOLLELA, 2017). Após se avaliar a adequação da técnica para a aprendizagem, realiza-se o planejamento dos módulos de aprendizagem. Os módulos de aprendizagem consistem no planejamento de disponibilizar conteúdo de aprendizagem, previamente, de forma que o discente seja capaz de desenvolver, criar ou inovar ao concluir os módulos de aprendizagem com sucesso, com retenção e entendimento dos conteúdos trabalhados (BOLLELA, 2017). A Pirâmide da Taxonomia de Bloom pode auxiliar no norteamento do planejamento pela definição dos objetivos educacionais a serem alcançados pela aula invertida num nível hierárquico de desenvolvimentos de habilidades de pensamento a ser trabalho junto aos discentes, Figura 1.

Utilizando a Pirâmide da Taxonomia de Bloom, pode-se estruturar melhor a organização hierárquica quanto aos objetivos educacionais a serem alcançados pela aula invertida (SCHNEIDERS, 2018). Assim, considerado, tem-se dos seis níveis apresentados pela Pirâmide de Bloom (JENKINS et al., 2017), partindo das habilidades de pensamento de ordem inferior (LOTS, do inglês - Low Order Thinking Skills), nos níveis mais baixos, seguindo na direção do desenvolvimento das habilidades de pensamento de ordem superior (HOTS, do inglês - Higher Order Thinking Skills), a etapa 6 (o topo da pirâmide) é a primeira a ser trabalhada na descrição do objetivo da aprendizagem. Definida esta primeira etapa, trabalha-se regressivamente para que as etapas anteriores sustentem as posteriores, a 5 em relação a 6 , a 1 em relação a 2. As unidades de aprendizagem não necessariamente precisam percorrer todos os seis níveis propostos pela taxonomia, entretanto, deve-se ter o objetivo bem estabelecido, etapa 6, pois o planejamento somente é realizado após a definição geral do objetivo de um módulo ou módulos. Como apresentado quando o planejamento se desenvolve das Habilidades de Pensamento de Ordem Superior (HOTS) para Habilidades de Pensamento de Ordem Inferior (LOTS), se tem o planejamento docente dos módulos de aprendizagem e estes módulos induzem ao discente a desenvolver suas habilidades e conhecimentos no sentido inverso do planejamento, isto é, dos LOTS em direção aos HOTS (SCHNEIDERS, 2018). Portanto, para o discente, as ações se iniciam pelos níveis mais baixos da Taxonomia de Bloom (assistir a vídeos, ler pequenos textos, buscar materiais alternativos, conhecer e aprender novos assuntos) e, nível a nível, evolui até o nível mais alto planejado pelo docente para uma unidade de aprendizagem específica, pratica da autonomia e organização, dentre outras.

Figura 1 - Pirâmide de Bloom.

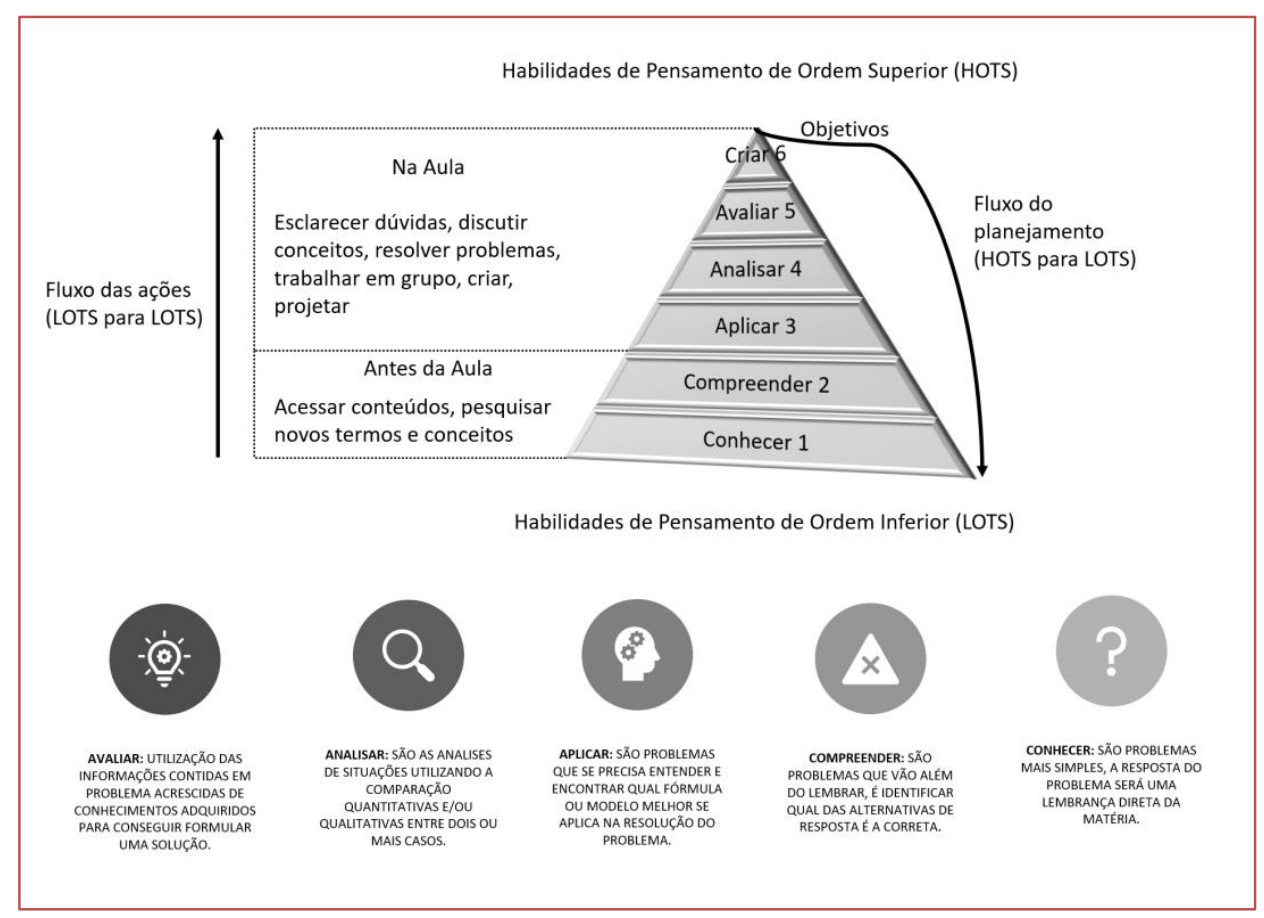

Fonte: Adaptado de Schneiders (2018) 
Quanto as ações para implantação da aula invertida, reforça-se como necessário: realizar planejamento prévio dos módulos de aprendizagem; ter, possuir ou produzir materiais apropriados disponibilizados previamente aos discentes, antes de cada módulo das aulas; fomentar por técnicas apropriadas os discentes para que sejam agentes ativos em seus próprios aprendizados; ser um docente facilitador em cada módulo proposto de aula e um avaliador da aprendizagem, após o término da atividade discente.

\section{METODOLOGIA}

A pesquisa-ação foi a metodologia empregada neste estudo, os discentes pesquisam não apenas os temas que buscam na ciência as possíveis soluções, mas também atuam como agentes-principais no aprendizado. A seguir, serão detalhadas as experiências em algumas disciplinas do curso de engenharia de materiais no Brasil.

Os participantes deste estudo incluíram, assim, discentes de um curso de engenharia de materiais envolvidos nas edições de aula invertida realizado no ano letivo de 2018, Tabela 2. De forma suscinta, temse que o conteúdo curricular, fornecido previamente antes do início de cada módulo, que incluía questionários e seminários, realizado em grupos de até 3 discentes, além de provas individuais ao final de cada módulo.

Tabela 2: Coleta de dados dos discentes

\begin{tabular}{|c|c|c|c|c|}
\hline Ano & Semestre & Código & $\begin{array}{c}\text { № de } \\
\text { discentes }\end{array}$ & Disciplina \\
\hline 2018 & 2을 Semestre & EMTI35 & 14 & FILMES FINOS (Optativa) \\
\hline 2018 & 2o Semestre & EMTI17.1 & 22 & $\begin{array}{l}\text { PROCESSAMENTO DE MATERIAIS METÁLICOS } \\
\text { (Obrigatória) }\end{array}$ \\
\hline 2018 & 1을 Semestre & EMTI10.1 & 15 & MATERIAIS METÁLICOS (Obrigatória) \\
\hline 2018 & 1을 Semestre & EMT055 & 17 & SOLIDIFICAÇÃO DE METAIS (Optativa) \\
\hline
\end{tabular}

Fonte: Teixeira et al. (2019)

O conteúdo curricular das aulas para estudo prévio foi disponibilizado aos discentes, antes do início de cada módulo de aprendizagem, pelo portal SIGAA (CARVALHO et al., 2011) da universidade (ao qual o discente tem acesso pelo CPF e senha pessoal) em módulos, conforme Figura 2. 0 discente, assim, tem acesso prévio ao conteúdo curricular em documento para baixar via SIGAA (links para download no SIGAA) como: textos bibliográficos acessíveis via Biblioteca Universitária e Google Acadêmico e vídeos técnicos-didáticos, Figura 2. Todo o conteúdo prévio fornecido ao discente (conteúdo bibliográfico, vídeos técnico-didáticos, exercícios dos módulos, provas no final de cada módulo e trabalhos em grupo) possibilita ao discente levantar dúvidas e elaborar comentários, o que conduz ao aprofundamento do aprendizado. Resumindo, no período da aula invertida, discute-se e se chega ao entendimento de todo o conteúdo curricular proposto, já vistos e trabalhados pelo discente nos módulos disponíveis no SIGAA, com o auxílio e a intermediação do docente facilitador e mediador do processo de aprendizado.

A aula invertida foi utilizada em quatro disciplinas diferentes do ciclo específico de um curso de Engenharia de Materiais no período de dois semestres consecutivos, Tabela 1. Nos dias da aula invertida para cada disciplina da Tabela 2, os módulos foram repassados, porém não da forma tradicional, pois considerando que os alunos já o haviam estudado previamente, o que possibilitou maior interação e resolução de dúvidas. Em momentos importantes ao térmico de cada módulo ou de conceitos importantes, foram fornecidos e apresentados vídeos e os exercícios de fixação para os grupos propostos aos discentes (grupo de 2 a 3 discentes), planejados de modo a nunca permitir mais do que 15 a 20 minutos de discussão de teoria. O SIGAA universitário, possibilitou ainda a criação de um fórum, monitorado pelo docente, de discussão da matéria, em conjunto com o perfil EMT-UNIFEI do Facebook na internet. Neste fórum, no SIGAA, os discentes colocavam dúvidas que surgissem durante a leitura e estudo do conteúdo, bem como auxiliavam aos colegas e tinham o auxílio periódico (quinzenal) do docente. 
Figura 2. Módulos acessíveis pelo SIGAA.

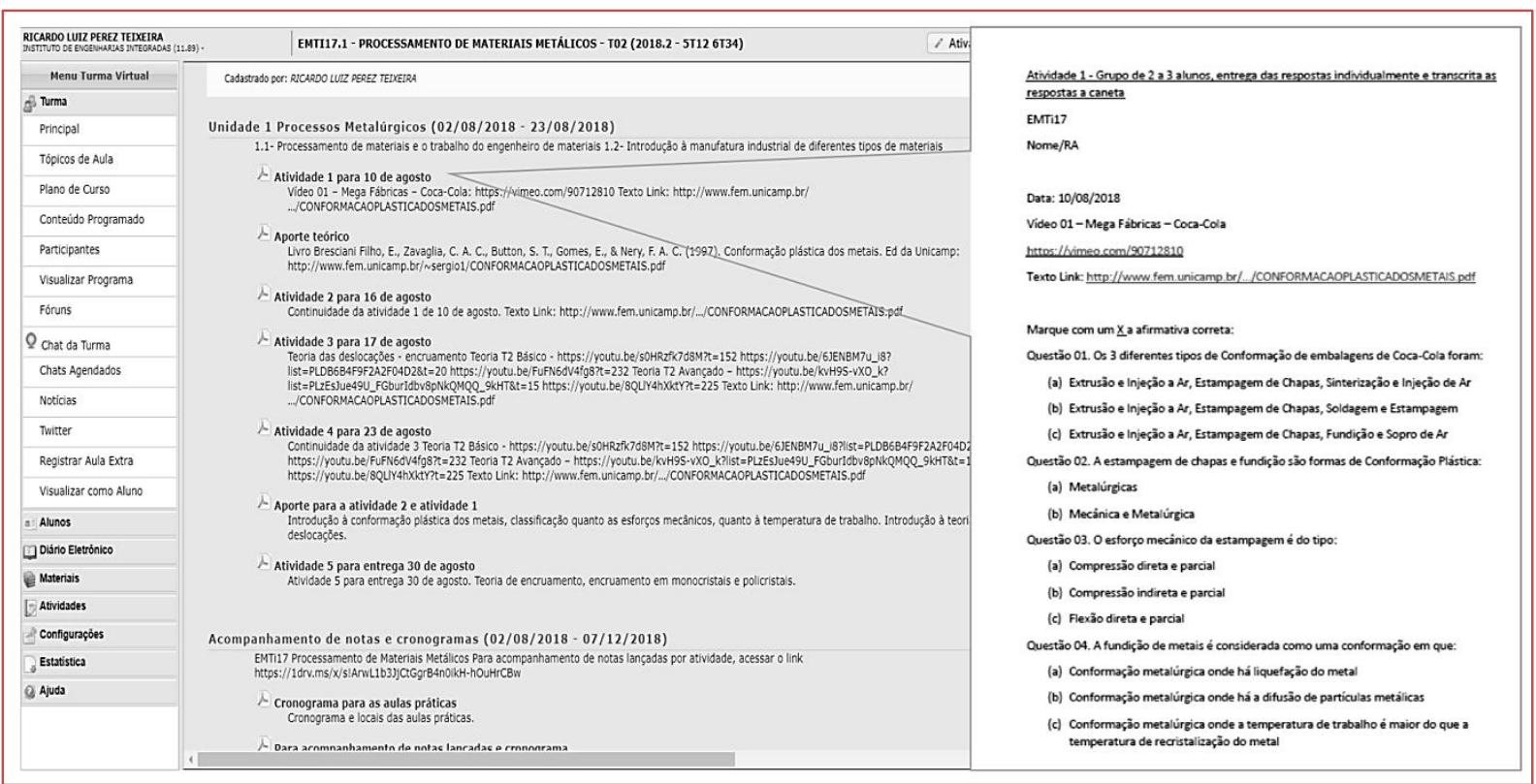

Fonte: Teixeira et al. (2019)

Tabela 3- Perguntas de Acompanhamento do Aprendizado

\begin{tabular}{|l|l|}
\multicolumn{1}{|c|}{ Perguntas } & Avaliação de 1 a 5 pelo \\
discente*
\end{tabular}

* 1,0 Não, definitivamente; 2,0 Não, parcialmente; 3,0 Sim, parcialmente; 4,0 Sim; 5,0 Sim, definitivamente

Fonte: Teixeira et al. (2019)

No início e após as provas finais individuais, foram realizadas avaliações do processo de ensino (APE), sendo somadas em conjunto as respostas discentes para as quatro disciplinas de estudo deste trabalho (Tabela 2), conforme DE REZENDE JÚNIOR et al. (2013). 0 APE, foi assim, dividido em Fase 1 (antes do início do módulo 1) e em Fase 2 (após a prova individual final). 0 APE apresenta parte da avaliação quantitativa de sete critérios coletados, por meio de questionário tipo survey, junto aos discentes onde: o conceito 1,0 representa o conceito (I) Insuficiente, 2,0 representa o conceito (R) Regular, 3,0 representa o conceito (B) Bom, 4,0 representa o conceito (O) Ótimo e 5,0 representa o conceito (E) Excelente), conforme Tabela 3. Em conjunto com o APE, realizou-se ao térmico da Fase 02, a avaliação acadêmica dos discentes de cada disciplina, dispondo-os em gráfico na Figura 3, com valores médios e o desvio padrão da média obtida pelos discentes em cada disciplina. 


\section{RESULTADOS}

A avaliação da aprendizagem e o desempenho dos discentes foi significativa (num total de 68 discentes), conforme resultados da Avaliação do Processo Educacional, APE proposto por De REZENDE JÚNIOR et al. (2013), com valor médio geral 4 (conceito ótimo), Figura 3, e desempenho superior a 7,0 (70\% ou conceito C, bom) para as duas Fases propostas na aula invertida, Figura 4.

Figura 3 - Consolidação de parte da Avaliação do Processo Educacional (APE)

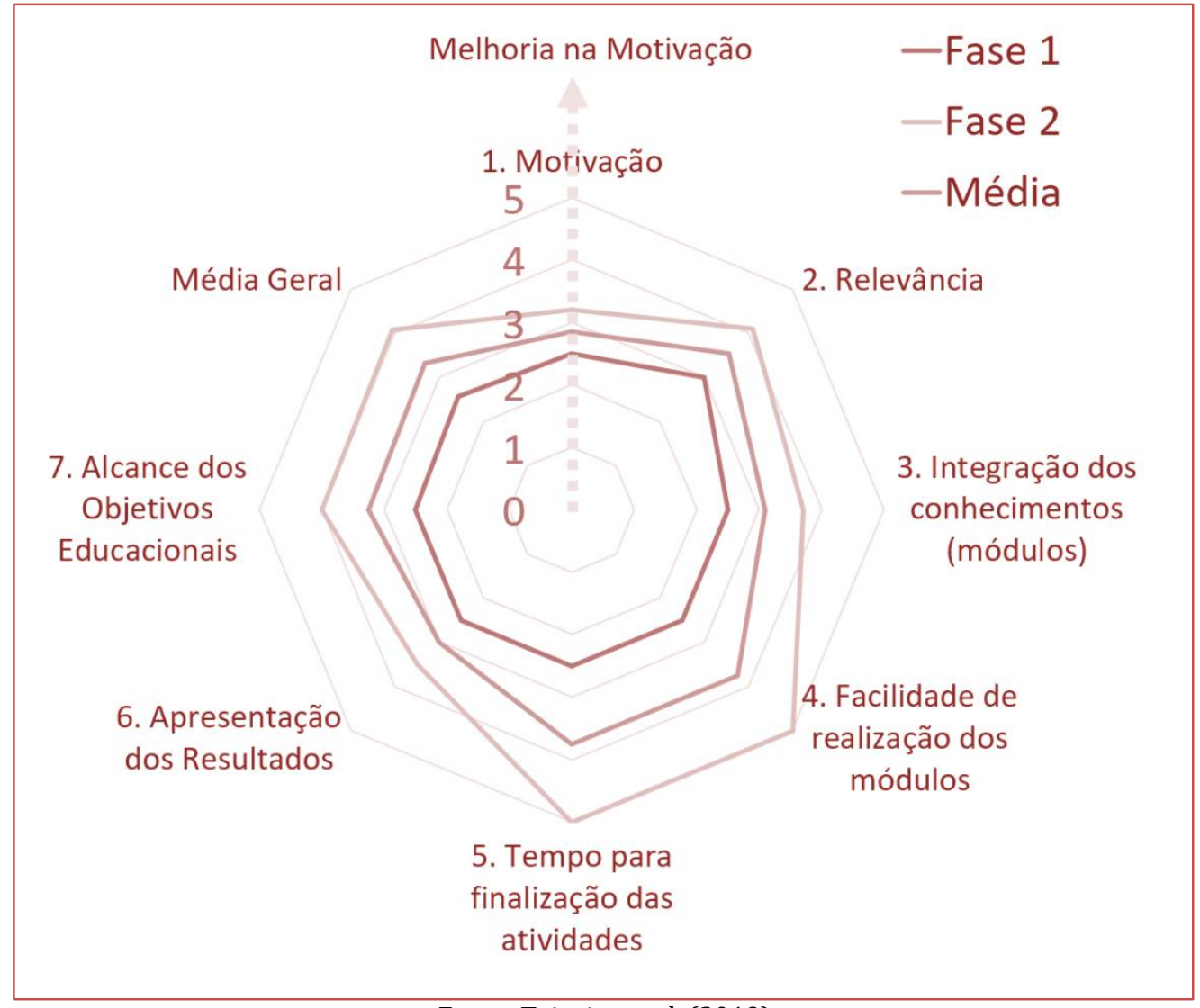

Fonte: Teixeira et al. (2019)

Pelo gráfico da Figura 3, tem-se uma tendência de maior dificuldade quanto aos resultados a apresentar (6) e a motivação (1) com o avanço de cada fase proposta, apesar da avaliação excelente quanto ao tempo de finalização das atividades (5). O SIGAA permite um controle melhor do tempo na divulgação das atividades e seus resultados (CARVALHO et al., 2011). Na Figura 3, tem-se um menor crescimento, da Fase 1 para Fase 2, na motivação (1) e nos resultados a apresentar (6), bem como da relevância (2), por parte de retorno discente, indicada pela seta. Infere-se ao menor crescimento de (1), (2) e (6) na Fase 2 ao contato, inédito, discente, com uma nova metodologia de aula invertida, em que o próprio discente é ativo no próprio aprendizado (média 3, considerado (B) Bom). 
Figura 4 - Média aritmética das notas dos discentes em cada disciplina.

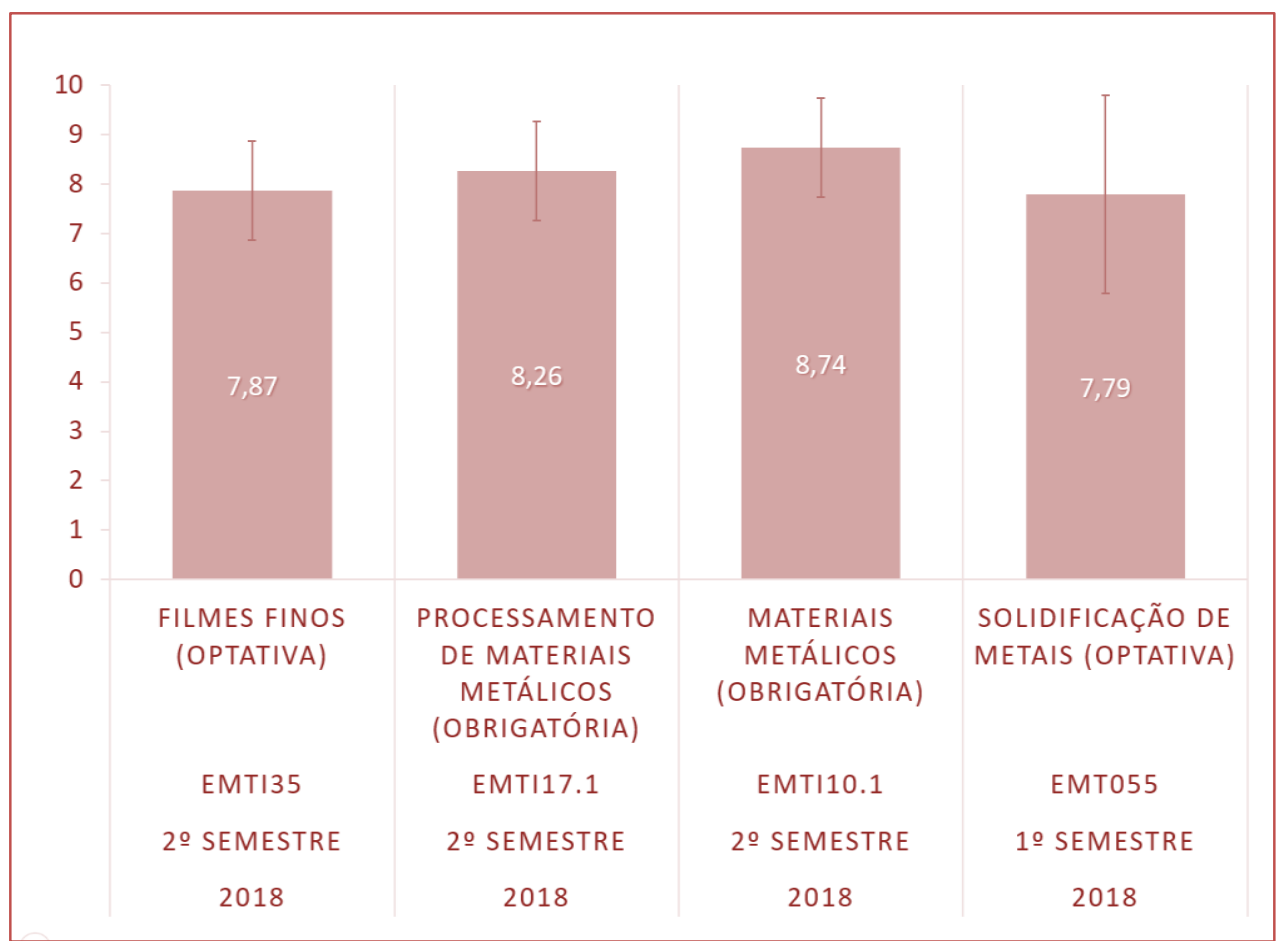

Fonte: Teixeira et al. (2019)

O desempenho acadêmico apresentado pelos discentes foi superior a 7,0 (70\% ou conceito C, bom) ao final de cada semestre, sendo que os melhores desempenhos médios foram alcançados pelos discentes nas disciplinas obrigatórias, apesar da proximidade dos resultados considerando o erro da média, segundo a Figura 4. Os melhores resultados no desempenho acadêmico para as disciplinas obrigatórias, conforme a Figura 4, são atribuídos à priorização das disciplinas obrigatórias por parte discente, pois elas seriam prérequisitos para disciplinas posteriores.

\section{CONSIDERAÇÕES FINAIS}

Os discentes apresentaram retorno positivo quanto ao aprendizado e ao desempenho acadêmico com o uso de metodologias ativas de aula invertida. Destaca-se, pela Avaliação do Processo Educacional discente, que a metodologia ativa por aula invertida possibilita fomentar a motivação discente, bem como um melhor uso do tempo de aprendizagem discente. Apesar de ser pequena a melhoria motivacional, segundo os resultados de APE. ela pode promover a percepção da integração de conhecimentos, a percepção da transdisciplinaridade por parte discente. A menção de práticas acadêmicas de metodologias ativas nas disciplinas está prevista no Plano Pedagógico atual do curso de engenharia de materiais apresentado neste trabalho.

\section{REFERÊNCIAS}

[1] ARNOLD-GARZA, Sara. The flipped classroom teaching model and its use for information literacy instruction. Communications in Information Literacy, v. 8, n. 1, p. 9, 2014.

[2] BOLLELA, Valdes Roberto. Sala de aula invertida na educação para as profissões de saúde: conceitos essenciais para a prática. Revista Eletrônica de Farmácia, v. 14, n. 1, 2017.

[3] CARVALHO, Rosângela S. et al. Integração entre o Sistema de Gestão Acadêmica e o Sistema de Gestão da Aprendizagem: Ação reflexiva na prática docente. Revista Opara, v. 1, n. 1, p. 215-229, 2011.

[4] De REZENDE JÚNIOR, R. A. et al. Aplicabilidade de metodologias ativas em cursos de graduação em engenharia. In: CONGRESSO BRASILEIRO DE EDUCAÇ̃̃O EM ENGENHARIA, 41, 2013, Gramado. Anais. Gramado: Cobenge, 2013. 
[5] JENKINS, Martin et al. Enhancing the design and analysis of flipped learning strategies. Teaching \& Learning Inquiry, v. 5, n. 1, p. 1-12, 2017.

[6] KARLSSON, Gunnar; JANSON, Sverker. The flipped classroom: a model for active student learning. From books to MOOCs, p. 127-136, 2016.

[7] SCHNEIDERS, Luís A. O método da sala de aula invertida (flipped classroom). Lajeado: Ed. da Univates, 2018.

[8] TEIXEIRA, R. L. P. et al. Utilização da sala de aula invertida em cursos de graduação em engenharia / Applying flipped classroom teaching model in a materials science and engineering course. The Brazilian Journal of Development, v. 5, n. 10, p. 19061-19072, 2019. 


\section{Capítulo 5}

\section{Laboratório de química: Um projeto de monitoria para disciplina de química inorgânica}

\section{Aline Joana Rolina Wohlmuth Alves Dos Santos}

\section{Charlene Barbosa De Paula}

Resumo: A atividade de monitoria pode ser entendida como uma potente ferramenta para a melhoria do processo de ensino e aprendizagem. Laboratório de Química é um projeto de monitoria que conta com apoio da Pró Reitoria de Ensino da Universidade Federal de Pelotas e atua com o intuito de auxiliar os discentes de graduação na disciplina de Química Inorgânica Experimental 1. Para isso, foram criados um site https://dequimicalaboratorio.wordpress.com, uma página nas redes sociais @quimicalaboratorio (Facebook) e um canal no Youtube https://www.youtube.com/channel/UCDDETZgG5DQS8x4IuJpWWnA que divulgam os vídeos produzidos na disciplina, durante a realização dos experimentos práticos a atuam como uma rede de comunicação entre os interessados no tema. 0 vídeo intitulado "Oxidação do ácido oxálico" foi disponibilizado, através do site, aos discentes da disciplina de Química Inorgânica Experimental 1 em atividade durante a aula e como tarefa para a aula. Para esta aula prática não houve roteiro experimental, sendo que todas as instruções para a realização da aula constavam no vídeo. A análise dos resultados foi realizada mediante uma investigação de caráter qualitativo das respostas dos discentes dadas para as questões disponibilizados em dois questionários, um inicial e outro final. Esta metodologia, sem roteiro experimental, usando apenas vídeos como material de instrução e entendimento mostrou-se viável e didática. Os discentes reproduziram o experimento compreendendo e comparando os resultados obtidos com os visualizados no vídeo, assim a atividade de monitoria propiciou um aprimoramento de conhecimentos aos discentes e à monitora.

Palavras-chave: Monitoria, Química Inorgânica Experimental, Vídeos 


\section{INTRODUÇÃO}

Um projeto de monitoria pode ser entendido como uma potente ferramenta para a melhoria do processo de ensino e aprendizagem, por meio de metodologias que permitam uma maior compreensão por parte dos discentes. Portanto a monitoria surge como um apoio pedagógico oferecido os discentes interessados em aprofundar seus conhecimentos sobre os conteúdos e solucionar dificuldades encontradas nos assuntos abordados na sala de aula, proporcionando um espaço de discussões e debates acerca das temáticas da disciplina (FERNANDES et al., 2015).

Laboratório de Química é um projeto de monitoria que conta com apoio da Pró Reitoria de Ensino (PRE), esta atividade de monitoria foi criada com o intuito de auxiliar os discentes de graduação na disciplina de Química Inorgânica Experimental 1 da Universidade Federal de Pelotas - UFPel. Para isso, foram criados um site, uma página nas redes sociais e um canal no Youtube que divulgam os vídeos produzidos na disciplina, durante a realização dos experimentos práticos. Os vídeos buscam facilitar, motivar e melhorar o processo de aprendizagem dos discentes que estão cursando a disciplina. De acordo com Moran (1995):

0 vídeo é sensorial, visual, linguagem falada, linguagem musical e escrita. Linguagens que interagem superpostas, interligadas, somadas, não separadas. Daí a sua força. Somos atingidos por todos os sentidos e de todas as maneiras. 0 vídeo nos seduz, informa, entretém, projeta em outras realidades (no imaginário), em outros tempos e espaços (MORAN, 1995, p. 28).

Com os avanços tecnológicos Viana (2004, p. 19), diz que "a sociedade atual, vivencia uma realidade, onde as crianças nascem e crescem em contato com as tecnologias que estão ao seu alcance" logo esse novo momento exige a busca por metodologias inovadoras, por estratégias pedagógicas que possam permitir uma interação dos discentes, através de ferramentas que possam estimular a aprendizagem. Assim, os vídeos produzidos e utilizados durante as aulas, neste trabalho, cumprem o papel de união das aulas da disciplina semestral com metodologias inovadoras (DE PAULA; SANTOS, 2019).

Frente às ações que vêm sendo realizadas, o objetivo deste trabalho é apresentar os vídeos produzidos e divulgados no site como sendo uma metodologia potencial para contribuir no processo de ensino e aprendizagem dos discentes da disciplina de Química Inorgânica Experimental 1, com foco no vídeo "Oxidação do ácido oxálico". Constantemente vídeos estão sendo gravados, editados e publicados pelo grupo nas mídias eletrônicas, Site, Facebook e Youtube.

\section{METODOLOGIA}

Inicialmente foram realizadas as gravações das atividades experimentais propostas para a disciplina de Química Inorgânica 1, então para isso foi preparado uma espécie de estúdio, com fundo branco, no laboratório de Química da UFPel onde as aulas são realizadas. A gravação dos vídeos é feita de maneira que não capture o som ambiente e para que apenas as mãos apareçam desenvolvendo o experimento (Figura 1a). Além da gravação do desenvolvimento dos experimentos são feitas fotografias, como por exemplo, a quantidade de reagentes pesados na balança analítica, produtos obtidos nas reações, entre outros, que durante a edição são incluídos no vídeo.

A edição dos vídeos foi feita em um programa de edição gratuito, assim ao final da edição é possível obter o vídeo em alta resolução e sem marcas d'água. Após inúmeras buscas o programa escolhido foi o "Wondershare Filmora 9" nesse programa foi possível realizar recortes dos vídeos, introduzir textos explicativos, fotografias, música de fundo, plano de fundo e efeitos.

Para tornar os vídeos mais explicativos, foram inseridos textos (Figura 1b) que guiam o experimento de maneira detalhada para que possa ser reproduzido em laboratório ou até mesmo para que servisse de reforço ao estudo após a realização do experimento em aula. 0 vídeo mostra o desenvolvimento de toda a atividade experimental, indicando os reagentes e suas quantidades, materiais e equipamentos a serem utilizados, procedimentos experimentais, explicações teóricas sobre os fenômenos observados, reações químicas e descarte de resíduos. 
Figura 1- (a) Gravação do vídeo da atividade experimental. (b) Textos explicativos inseridos no vídeo.
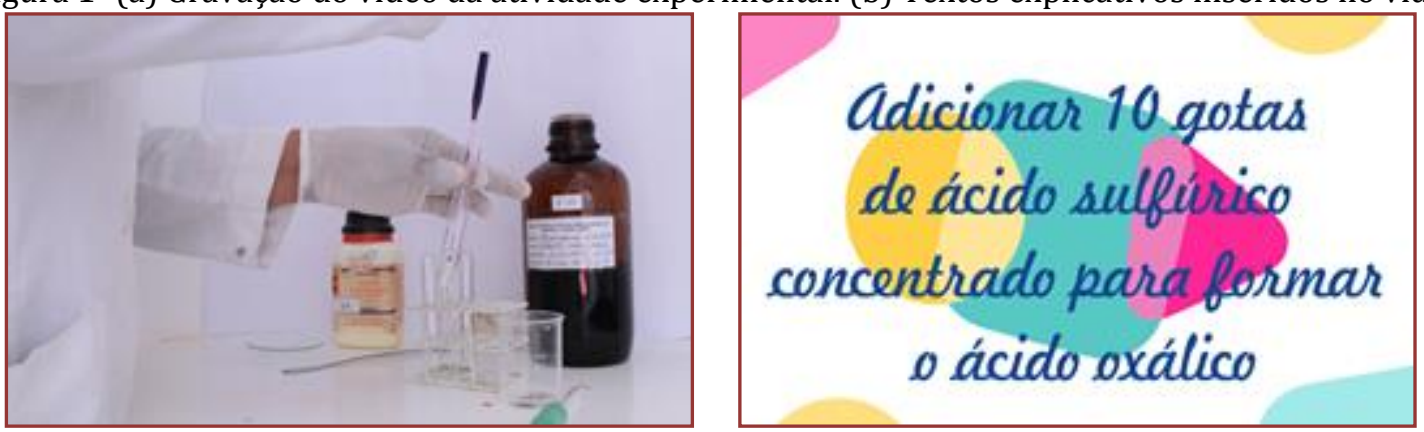

As fotografias feitas durante a atividade experimental foram inseridas nos vídeos para que o discente pudesse comparar as imagens do vídeo com o que será ou foi observado durante a atividade experimental. Além das fotografias, foram inseridas imagens dos materiais a serem utilizados durante a atividade prática contendo seu nome. Para os reagentes é inserido o nome, pictogramas e fórmula molecular.

O vídeo "Oxidação do ácido oxálico" foi apresentado na disciplina de Química Inorgânica Experimental 1 com a finalidade dos discentes reproduzirem o experimento no laboratório. Foram criados dois questionários (inicial e final) como uma forma de análise da atividade, os discentes foram instruídos previamente a acessar o site e assistir o vídeo antes da realização da atividade experimental. Como reforço, no dia da atividade os discentes assistiram o vídeo no LIG (Laboratório de Informática de Graduação) da Universidade e tiveram a possibilidade de fazer registros e anotações, caso julgassem necessário. Para esta aula prática não houve roteiro experimental, sendo que todas as instruções para a realização da aula constavam no vídeo.

A análise dos resultados foi realizada mediante uma investigação de caráter qualitativo das respostas dos discentes dadas para as questões dos questionários inicial e final. Foi utilizada, como metodologia, a Análise de Conteúdo de Moraes (1999), buscando seguir as etapas tidas como essenciais pelo autor. A atividade foi realizada contando com a participação de 17 discentes de duas turmas da disciplina. Mantendo o anonimato dos estudantes, as respostas foram codificadas, apresentando as seguintes categorizações A1, A2, etc., para os discentes participantes.

\section{RESULTADOS E DISCUSSÃO}

0 vídeo foi divulgado em três modalidades Facebook, Site e Youtube. A página nas redes sociais @quimicalaboratorio (Facebook) contém notícias sobre o projeto e um link direto para o site na plataforma gratuita Wordpress, https://dequimicalaboratorio.wordpress.com. No site foram criadas abas que permitem encontrar a descrição do projeto, notícias, fotos, informações sobre a equipe, assim como os vídeos das atividades experimentais após a edição. Como o site não permite que os vídeos sejam incorporados diretamente é necessário primeiramente importar os vídeos no Youtube, então foi criado um canal "Laboratório de Química" acessado através do link https://www.youtube.com/channel/UCDDETZgG5DQS8x4IuJpWWnA. Os vídeos abrangem, em média de seis experimentos para cada grupo da Tabela Periódica, Grupos 1, 2, 13, 14, 15, 16, 17, além de experimentos envolvendo reações inorgânicas e de reações de hidrogênio.

Pensando nos vídeos didáticos como um novo recurso para o processo de ensino e aprendizagem dos discentes, Almeida, Ayala e Quadros (2018) dizem que:

As vídeoaulas são ferramentas que podem ser utilizadas no ensino, visto que a informação chega ao espectador de maneira pedagogicamente organizada e a interação entre o aprendiz e a tela do computador se dá por meio da linguagem audiovisual (ALMEIDA; AYALA e QUADROS, 2018, p. 289). 
O site permite que os discentes possam assistir as atividades experimentais propostas para a disciplina, podendo a qualquer momento parar o vídeo em alguma dúvida ou até mesmo para comparar com suas anotações das aulas práticas, assim auxiliando tanto na montagem dos relatórios, como para estudos futuros.

Os questionários inicial e final apresentavam um total de 10 questões cada, foram analisadas as respostas para a questão número 2 do questionário inicial: “0 que você aprendeu ao assistir o vídeo?”. Desse modo, forma analisados alguns dos escritos dos discentes.

“O passo a passo para a realização do experimento e como ocorre a oxidação do ácido e como ela pode ser observada no experimento" (A1).

"Aprendi como realizar o experimento e a reação de oxidação e redução que acontece com os elementos em uma reação" (A2).

Após analisar os questionários, percebeu-se que a maioria dos discentes apontou que com o auxílio do vídeo foi possível conhecer os procedimentos experimentais de maneira detalhada, assim facilitando sua reprodução no laboratório, uma vez que já conheciam as vidrarias e reagentes que seriam utilizados, além de já terem observado o ponto final da reação proposta, neste caso do processo químico de oxirredução.

No questionário final foram analisadas as respostas para a questão número 10: "Na sua opinião foi válido o uso deste material de apoio, o vídeo, no processo de aprendizagem?". Desse modo analisou-se os escritos dos discentes A1 e A2.

“Sim, pois com ele é possível ter um esclarecimento maior do proceder do experimento" (A1).

"Sim, pois o vídeo é bem explicativo e completo" (A2).

Com base nas respostas obtidas percebeu-se que os discentes de maneira geral defendem o uso desse material de apoio, por se tratar de um vídeo didático e explicativo contribuindo assim para o processo de aprendizagem.

\section{CONCLUSÕES}

Com a atividade realizada com os discentes foi possível perceber que o vídeo foi benéfico para o desenvolvimento da atividade experimental, uma vez que o vídeo foi apresentado de maneira didática, sendo um suporte importante para a aula experimental, percebeu-se que os discentes reproduziram o experimento compreendendo e comparando os resultados obtidos com os visualizados no vídeo, assim contribuindo para a aprendizagem dos discentes.

A experiência na monitoria foi de suma importância para mim, monitora, pois adquiri conhecimentos em áreas distintas como elaboração de vídeos, criação e manutenção de site, além de todo o estudo destinado aos conceitos científicos abordados para produzir os vídeos didáticos. Assim como os vídeos didáticos me propiciaram um aprimoramento dos conhecimentos, acredito que os discentes presentes na disciplina e em outros níveis da graduação possam se beneficiar da mesma forma. Portanto, a monitoria se trata de um espaço de reflexão sobre sua própria prática e ensino, além de possibilitar um crescimento de pensamento sobre novas metodologias de ensino.

\section{REFERÊNCIAS}

[1] Almeida, L. T. G.; Ayala, J.D.; Quadros, A. L. As Videoaulas em Foco: Que Contribuições Podem Oferecer para a Aprendizagem de Ligações Químicas de Estudantes da Educação Básica? Química Nova na Escola, Vol. 40, N 4, 2018, p. 287-296. http://dx.doi.org/10.21577/01048899.20160132 .

[2] De Paula, C.B.; Santos, A.J.R.W.A. Laboratório de Química: um projeto de monitoria para disciplina de Química Inorgânica. 5a Semana Integrada da Universidade Federal de Pelotas (UFPel), V Congresso de Ensino de Graduação, 2019, Pelotas. Anais. Disponível em: <http://cti.ufpel.edu.br/siepe/arquivos/2019/MD_02708.pdf>. Acesso em: 25 de novembro de 2019.

[3] Fernandes, N. C. et al. Monitoria acadêmica e o cuidado da pessoa com estomia: relato de experiência. Revista Mineira de Enfermagem, Belo Horizonte, v.19, n. 2, 2015,p.238-241.

[4] Moraes, R. Análise de conteúdo. Educação. v. 22, n. 37, p.7-32,1999.

[5] Morán, J. M. 0 vídeo na sala de aula. Comunicação e Educação, v. 2, 1995, p. 27-35.

[6] Viana, M. A. P. Internet na Educação: Novas formas de aprender, necessidades e competências no fazer pedagógico. In: Mercado, L. P. L. (Org.) Tendências na utilização das tecnologias da informação e comunicação na educação. Maceió: Edufal, 2004. 228p. 


\section{Capítulo 6}

Aplicação da metodologia PBL (Problem Based Learning) em uma disciplina inicial dos cursos de Engenharia Civil

Juan Carlos Gerez

Gabriele Azambuja Coelho Rodrigues

Karoline Pereira Fagundes

Lucas Gonçalves de Freitas

Bianca Pereira Moreira Ozório

Resumo: Este trabalho relata sobre duas aplicações de uma metodologia de ensino ativa conhecida por PBL (Problem Based Learning) nos cursos de Engenharia Civil e Engenharia Civil Empresarial da Universidade Federal do Rio Grande - FURG. O Projeto, realizado por dois anos, é fruto de uma parceria entre docentes e Grupo PET-Engenharia Civil da Universidade. Além de discorrer sobre a maneira que foi aplicada, o artigo também faz uma breve descrição do que se trata a metodologia, vantagens e as justificativas que levaram a abordagem desse tema na graduação. Na metodologia, aluno é o protagonista do conhecimento que deverá adquirir com a resolução de uma situaçãoproblema de temas pertinentes a sua formação. Cabe ao professor apenas dirigir o estudante para uma correta solução. A temática surgiu diante as novas necessidades do mercado de trabalho que solicita por um profissional mais completo, ou seja, com habilidades não só técnicas, mas também habilidades sociais, visando manter a motivação dos alunos de primeiros anos da graduação com a carreira escolhida. Na primeira abordagem, os alunos tiveram como situação-problema o desenvolvimento de uma parada de ônibus do Campus Carreiros da FURG enquanto que na segunda abordagem tiveram que resolver problemas relacionados ao sistema cicloviário do município de Rio Grande/RS.

Palavras-chave: Engenharia Civil. Metodologia de Ensino Ativa. Evasão. Metodologia PBL. Calouros. 


\section{INTRODUÇÃO}

Este artigo contempla a realização da aplicação da metodologia PBL (Problem Based Learning) nos anos de 2017 e 2018 nos cursos de Engenharia Civil e Engenharia Civil Empresarial, na Universidade Federal do Rio Grande - FURG. "A metodologia de ensino PBL é uma abordagem instrucional que utiliza um problema da vida real para enfocar, motivar e facilitar o processo de aprendizagem de conhecimentos conceituais, procedimentais e atitudinais relevantes à futura atuação do aluno como profissional e cidadão." (Ribeiro, p. 23, 2008).

Conforme disposto na Resolução № 18/2008 do Colegiado Especial da FURG, a Escola de Engenharia (EE) foi criada em agosto do ano de 2008. Atualmente, a Unidade organizacional executiva da FURG abrange as áreas do conhecimento inerente aos cursos de graduação em Engenharia Civil, Engenharia Mecânica, Engenharia Civil Empresarial, Engenharia Mecânica Empresarial, Engenharia Civil Costeira e Portuária, Engenharia Mecânica Naval e, recentemente, o curso Engenharia de Produção. 0 curso de Engenharia Civil é datado desde 1972 na Universidade sendo um dos cursos mais antigos de todos que, hoje, são ofertados.

Assim como outras escolas de engenharia, na FURG a metodologia tradicional de ensino, é a mais utilizada, sendo baseada na transmissão de conteúdos através de aulas expositivas. Engajados em mudar essa visão e promover uma melhora no processo de aprendizagem dos acadêmicos de engenharia, o Grupo PET (Programa de Educação Tutorial) em Engenharia Civil da FURG em parceria com parte do corpo docente da Unidade Acadêmica em questão iniciaram o desenvolvimento na aplicação de uma metodologia ativa de ensino que pudesse ser aplicada dentro da Engenharia.

Segundo Izeki e Nagai (2013, apud Cristensen et al., 1991) o modelo tradicional de ensino é caracterizado pela transferência de informação de um especialista, o professor, para os discentes. Essa troca de experiências é limitada a breves perguntas e respostas, poucas ou nenhumas interações com os alunos. 0 mesmo autor defende que não importa o nível de competência do docente, esse não consegue envolver os alunos no processo de aprendizagem. Logo, para Izeki e Nagai, indiretamente priva os discentes de experiências de aprendizagem e oportunidades que só poderiam concretizar utilizando estratégias de engajamento ou cooperação (2013, apud akili, 2011). Kuri (2004) defende que na engenharia, o acelerado aumento nos programas de pesquisa e desenvolvimento, somado ao avanço científico e a explosão da tecnologia de informação e comunicação, evidencia a necessidade de se formar um novo profissional de engenharia. A autora entende que o engenheiro deve possuir uma formação mais ampla que contemple uma formação humanística, deve ser flexível e dinâmico, possuir a capacidade de liderar e comunicar. Assim, cabe ao professor o grande desafio de fornecer essa formação não apenas ao estudante, mas também a todas essas necessidades que tange às novas demandas. Essa busca metodológica qualitativa para obter uma melhor eficiência no aprendizado é alcançada pela abordagem pedagógica denominada por aprendizagem ativa anteriormente citada. Izeki e Nagai (2013, apud Akili, 2011) denominam por aprendizagem ativa aquela que requer atividades de aprendizagem significativa em grupos supervisionados por um professor mais experiente, mentor do conhecimento.

Dessa forma, o PBL torna-se muito adequado para as aulas introdutórias às ciências e engenharia, uma vez que contribui para desenvolver habilidades e confiança para a resolução de problemas que eles nunca observaram.

Nesse contexto, no ano de 2017 a metodologia foi aplicada pela primeira vez através da parceria entre PET Engenharia Civil e o Professor responsável pela turma da disciplina Introdução à Engenharia Civil. Uma disciplina direcionada para apresentar a profissão aos 75 novos ingressantes do curso, os deveres e os desafios do profissional de engenharia. A aplicação do projeto ocorreu durante todo o segundo semestre letivo do ano anteriormente citado. Em 2018, a parceria se repetiu e além dos outros 75 ingressantes do curso de Engenharia Civil do mesmo ano, a metodologia também foi aplicada aos 50 ingressantes do curso de Engenharia Civil Empresarial por o mesmo período de tempo.

\section{REFERENCIAL TEÓRICO}

O Problem Based Learning - PBL é uma metodologia de ensino colaborativa, construtiva e contextualizada. Aproveita-se de situações problemas para direcionar e motivar o processo de aprendizagem de conceitos, desenvolvimento de habilidades transversais como liderança, comunicação, trabalho em equipe e proatividade (Sesoko, 2014). Durante sua aplicação, o aluno é exposto a um problema inicial e sem o conhecimento inicial deve desenvolvê-lo através da orientação do professor. Nessa metodologia, o aluno é o protagonista do conhecimento e o professor é apenas o facilitador do processo de aprendizagem, todos de forma cooperativa em busca de soluções. 0 problema pode ser real ou, então, um problema idealizado, 
pode apresentar diversas soluções, fáceis ou complexas para que incentive os estudantes buscarem considerações com base técnica para solucioná-lo. É uma metodologia multidisciplinar porque para a resolução de um único problema induz o estudante explorar outras áreas do conhecimento. A aprendizagem é independente, estimulada e recompensada porque fomenta as capacidades de análise, decisão e impulsiona o pensamento crítico e criativo. Tem por principal objetivo as decisões e considerações adotadas e os questionamentos feitos para chegar à resolução final do problema.

Entre as vantagens do PBL, Ribeiro (2016) defende que a mais citada é a capacidade de tornar a aprendizagem mais dinâmica e prazerosa, compartilhada entre discentes e docentes. Confere aos alunos uma maior motivação para o trabalho desde os primeiros anos de formação e fomenta um ambiente de aprendizado onde o companheirismo é mais compartilhado uma vez que os alunos estão divididos em grupos de trabalho. Os estudantes aprendem a respeitar opiniões diversas e a construir consensos.

Cabe ressaltar que a utilização de metodologia ativa desenvolve, também, habilidades não técnicas, mas que são essenciais a um profissional de engenharia que na maioria das vezes está limitado ao conhecimento técnico. Kuri (2004, apud. Landi, 1996, p.12) esclarece que para essa formação em gestão há a necessidade de se entender as relações sociais "porque já se percebeu que não dá para conversar com as pessoas puramente no racional; é preciso interpretar toda a formação cultural, as emoções e os sentimentos das pessoas. [...] 0 engenheiro precisa saber interpretar as pessoas e gerar a motivação, que é a única base da produção.".

Como defendido por Masson et al. (2012) para o sucesso do Problem Based Learning principalmente quando se fala em ensino em engenharia é fundamental a gestão da aprendizagem de forma que simplifica a administração de programas educacionais, possibilita a disponibilização e a análise do conteúdo e o aperfeiçoamento do ensino.

\section{JUSTIFICATIVAS}

A aplicação da metodologia, além das vantagens já relatadas pelo método, teve outro ponto de motivação: a necessidade de se criar práticas para combater a evasão inicial nos cursos de engenharia e a desmotivação dos alunos em seguir com a carreira. De maneira geral, os cursos de engenharia são divididos entre disciplinas que nesse artigo vamos chamá-las de profissionalizantes e ciclo básico. As disciplinas profissionalizantes são aquelas técnicas da carreira escolhida além das disciplinas de formação social e humana do profissional. As disciplinas de ciclo básico são aquelas recorrentes a todas as engenharias que englobam disciplinas de Cálculo Integral e Diferencial, Física, Geometria Analítica e Álgebra Linear que servirão de base para disciplinas futuras da engenharia. 0 que ocorre na maioria dos cursos é que o aluno, quando exposto à essas disciplinas do ciclo básico, se decepcionam pela dificuldade de acompanhar a matéria que exige maior dedicação do que estavam acostumados em épocas de ensino fundamental e médio. 0 resultado disso é a grande repetência no início do curso somado a escolha precipitada de uma profissão. Além disso, o fato de não estarem em contato com as disciplinas técnicas provoca falta de identidade com a carreira que elegeram. Pereira et. al (2006) também destacou que a evasão nos cursos de engenharia podem ter origem com a baixa maturidade dos alunos associadas aos problemas recorrentes nas disciplinas do ciclo básico em cursos de engenharia, além da, escolha precipitada da carreira, falta de paciência, disciplina e dedicação, falta de perspectiva de quando será usado todo o ferramental básico nas disciplinas do ciclo básico e técnicas da profissão.

As Diretrizes Curriculares Nacionais do Curso de Graduação em Engenharia, instituídas em 2002 pelo Conselho de Educação Superior do MEC (Ministério da Educação e Cultura) estabelecem que o profissional de engenharia formado no Brasil deve reunir habilidades humanistas, críticas e reflexivas (Calvancante \& Embiruçu, 2013 apud. BRASIL, 2002) além da capacidade de associar, absorver e desenvolver tecnologias, atuação criteriosa e criativa na identificação e resolução de problemas. Os mesmos autores relatam que segundo um trabalho do MEC publicado em 1996 pela Comissão Especial de Estudos sobre a Evasão nas Universidades Públicas Brasileiras, 53 Instituições de Ensino Superior Pública (IESP) do país que representavam 67,1\% desse universo e 89,7\% Universidades Federais do país (Calvancante \& Embiruçu, 2013 apud. Brasil, 1996). 
Dentre as possíveis causas identificadas no estudo que levam os alunos a deixarem os cursos superiores (o que ocorre principalmente nos dois primeiros anos do curso) foram identificados: 1. Currículos longos e desatualizados além da falta de clareza sobre o projeto pedagógico do curso; 2. Critérios impróprios de avaliação do desempenho discente; 3. Falta de formação pedagógica ou desinteresse do docente; 4. Ausência ou pequeno número de programas institucionais de suporte para o estudante; 5. Cultura institucional de desvalorização da docência na graduação; e 6. Insuficiência de estrutura de apoio ao ensino de graduação, como falta de laboratórios de ensino e equipamentos de informática. (Calvancante \& Embiruçu, 2013 apud. Brasil, 1996).

Vale ressaltar que o conceito de evasão é relativo para alguns autores porque defendem que o aluno que realiza sua transferência de matrícula para outro curso ou IES não evadiu do sistema de educação superior. Para o INEP (Instituto Nacional de Estudos e Pesquisas Educacionais Anísio Teixeira Legislação e Documentos), esse fato não é levado em conta na avaliação, apenas realizam balanços anuais dos alunos que ingressaram se graduaram ou trancaram sua matrícula. Com base nesses dados Filho et al. (2007) avaliou as estatísticas de evasão anual entre os anos de 2000 a 2005 e constatou que nas IES públicas oscilaram em torno dos $12 \%$, variando entre 9 e 15\% no período. Nas IES privadas a oscilação chegou em torno dos $26 \%$ contra uma taxa nacional típica de $22 \%$.

Por os diversos fatos já relatados, entendeu-se que aplicação da Metodologia Problem Based Learning (PBL) é uma alternativa para motivar o aluno a seguir no sistema de ensino superior, sobretudo, despertar suas habilidades intrínsecas para o futuro profissional. Além da possibilidade de tornar os cursos de engenharia mais atraentes e estimulantes, torna-se uma alternativa pedagógica mais interessante para elevar as taxas de formação e a qualidade do profissional de engenharia do país.

\section{PROPOSTAS DE APLICAÇÃO}

Na Universidade Federal do Rio Grande - FURG a metodologia foi aplicada no curso de Engenharia Civil na disciplina de Introdução a Engenharia Civil pela primeira vez no ano de 2017. No exemplo abordado, os alunos matriculados na disciplina receberam a seguinte problemática: Desenvolver uma parada de ônibus para o Campus Carreiros da FURG num local já determinado pelo docente e monitores do projeto (bolsistas do PET-EC). O PET é um grupo de estudantes, com a tutoria de um docente, organizados a partir de formação em nível de graduação na IES do País orientados pelo princípio da indissociabilidade entre ensino, pesquisa e extensão e da educação tutorial (BRASIL, 2019). A proposta da parada de ônibus fez com que os participantes analisassem o problema e buscassem soluções para resolvê-lo de algo que vivenciam diariamente. 0 fato de envolver problemáticas reais e aplicáveis instiga os alunos e torna 0 ensino mais relevante para as suas vidas. A proposta foi aplicada por meio de intervenções que o Grupo PET-EC realizava nas aulas da disciplina em questão, ou seja, a metodologia de ensino tradicional não foi totalmente abandonada na disciplina porque se entendeu que uma mudança total e rápida poderia impactar negativamente os alunos. Assim, através do processo gradual, a ementa original da disciplina não era afetada evitando problemas com procedimentos acadêmicos.

O plano de ensino da metodologia que foi aplicada dividiu a proposta em quatro etapas sendo a primeira concentrada na abordagem da situação-problema e possível solução inicial valendo do conhecimento que os alunos dispunham. A segunda etapa priorizava o desenvolvimento do conhecimento individual. A terceira etapa foi desenvolvida em grupo de forma tutorial a fim de promover a troca de conhecimento, raciocínio e comunicação, e por fim, a quarta e última etapa consistiu na formulação da solução para a situação-problema. Antes de iniciar cada etapa, uma intervenção na aula era realizada. Seguindo os passos supracitados, a abordagem, das etapas foi abordada da seguinte maneira na primeira aplicação da metodologia:

- Na 1 $1^{\text {a }}$ Etapa, os alunos foram divididos em grupos de até 7 acadêmicos com o intuito de promover a troca de conhecimentos. Juntos, deveriam elaborar uma primeira solução a partir dos seus conhecimentos empíricos. Como auxílio, foram disponibilizadas, virtualmente, as respostas de um questionário online realizado através da Plataforma Google Formulários meses antes da aplicação quando o planejamento ainda estava sendo construído, para os acadêmicos e usuários do transporte coletivo do Campus Carreiro. 
0 intuito da pesquisa, que contou com 134 respostas, era avaliar as atuais condições das paradas do Campus e suas principais necessidades. As respostas coletadas serviram de embasamento para abordagem do tema, formulação da problemática e direcionamento da metodologia aplicada juntamente aos alunos da disciplina envolvida. Os entrevistados tiveram que elencar uma nota as atuais paradas do Campus da Universidade, selecionar problemas pré-existentes como conforto térmico, falta de acessibilidade e proteção contra intempéries e, por fim, um espaço foi destinado para comentários.

- A 2a Etapa, agora realizada individualmente e com duração de três semanas, os alunos deveriam buscar bibliografias que os auxiliassem na resolução do problema.

- A 3 ${ }^{\text {a }}$ Etapa desenvolvida novamente em grupo teve a duração de 4 semanas. Os grupos tinham a missão de trocar suas informações coletadas entre eles e com os monitores e docente responsável pela disciplina que nesse momento, tinham o papel de apenas direcionar os estudantes para uma solução viável de acordo com as bibliografias e propostas levantadas pelo grupo.

- A 4 4 a Etapa e última teve a duração de mais 4 semanas e compreendeu a elaboração final, entrega e apresentação da proposta finalizada da problemática. Ao fim de cada Etapa, os acadêmicos deveriam entregar relatórios que serviram de acompanhamento do projeto, desenvolvimento do grupo ao longo do tempo e avaliação final.

Em 2018, como relatado anteriormente, o projeto foi aplicado em mais um curso. Agora nos cursos de Engenharia Civil e Engenharia Civil Empresarial a metodologia passou a ser realizada novamente durante o segundo semestre do ano letivo. Com outra situação problema, os alunos foram novamente divididos em grupos de até 7 pessoas para iniciar os trabalhos. Agora, os participantes tinham a missão de resolver a seguinte problemática: Projetar de uma ciclovia ou ciclofaixa situada na cidade do Rio Grande com no mínimo $3 \mathrm{~km}$ de comprimento e que deveria, obrigatoriamente, ligar-se a uma ciclovia ou ciclofaixa já existente na cidade. Novamente, na primeira intervenção realizada com as turmas foram repassados nomes e contatos dos monitores e docentes que poderiam auxiliar com o desenvolvimento do trabalho. No final de 2017, ao final da aplicação pela primeira vez, foi realizada uma avaliação do projeto com os alunos para que erros pudessem ser corrigidos e melhorados. Por isso, foi bastante enfatizado a importância de estreitar a comunicação dos grupos com monitores e docentes em prol de um melhor resultado final. 0 procedimento da aplicação seguiu o mesmo processo aplicado anteriormente, com a divisão do projeto em

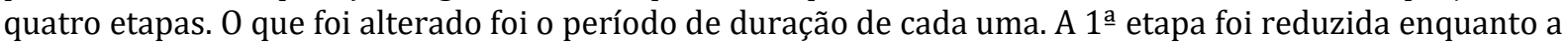
$3^{\text {a }}$ teve seu tempo dobrado. 0 que foi incluído também foi à chamada "sessão de palestras" durante a aplicação da segunda edição. A "sessão de palestras" consistiu na realização de palestras técnicas antes do início de cada etapa para instigar os alunos com o assunto e motivá-los na busca de boas soluções. As palestras foram realizadas pelo próprio corpo docente com ênfase na área de Transportes da Escola de Engenharia. Foi apresentado aos acadêmicos não só conceitos pertinentes à situação problema como também projetos já realizados no Campus Sede e pesquisas acadêmicas na área.

Nas duas edições, para desenvolver melhor as vantagens de liderança e comunicação já conhecidas da metodologia, os integrantes deveriam escolher entre eles três papéis: coordenador, relator e comunicador. 0 coordenador se encarrega de dividir as tarefas e conduzir o andamento do trabalho garantido a motivação do grupo; o relator era o responsável por garantir a entrega de todos os relatórios ao final de cada etapa; o comunicador, como o próprio nome já revela, era o responsável por realizar a comunicação do grupo com monitores e docentes, marcando encontros e atualizando a todos as informações sobre o andamento do projeto.

\section{CONSIDERAÇÕES FINAIS}

A implantação do PBL, além de agregar conhecimento ao aluno, incentiva o contato com profissionais da área, podendo assim absorver os conhecimentos teóricos e colocá-los em prática nos anos iniciais da graduação. Dessa forma, visa que o número de desistências dos cursos de engenharia sofra significativa redução. A aplicação da metodologia na FURG teve como principal objetivo instigar os alunos e promover a motivação e melhorias na compreensão dos conceitos e no rendimento acadêmico, resultando em uma formação participativa, crítica e reflexiva.

Mudar de um sistema tradicional de ensino pautado no professor como o único mentor do conhecimento e aulas somente expositivas é uma tarefa difícil. Por isso o processo deve ser gradual. 
A sociedade em geral vive em um século que as mudanças acontecem num espaço de tempo muito curto. Todos os dias, recebemos novidades tecnológicas e informações que circulam todo o mundo em minutos por exemplo. 0 mercado de trabalho também possui outras demandas. Necessita de profissionais mais completos que estejam preparados para lidar com os desafios da profissão. Aplicar a metodologia significa colocar os alunos na situação de um futuro profissional ainda durante a graduação e dentro da sala de aula. Quando os estudantes trabalham em grupo, aprendem a respeitar opiniões alheias e se tornam, progressivamente, responsáveis por sua própria aprendizagem.

Outra vantagem que justifica a aplicação da metodologia é o pensar técnico em engenharia por esses alunos. No primeiro ano da aplicação, quando os alunos tinham a situação problema da parada de ônibus, percebeu-se que eles estavam preocupados com o conforto térmico das paradas, segurança dos usuários, proteção aos intemperes como chuva e vento, arquitetura e história do Campus Carreiros, solo da região e os benefícios com a construção de uma parada sustentável. No segundo ano, notou-se durante a situação problema da ciclovia/ciclofaixa que a prioridade para todos os trabalhos apresentados foi à segurança dos usuários. Nesse contexto, incluem citar sinalização adequada, barreiras de proteção e campanhas de incentivo ao uso de bicicleta e outros modais leves de transporte. Mais uma vez, o resultado mostrou a preocupação de um desenvolvimento mais sustentável por esses futuros engenheiros que a cada ideia, tinham um novo obstáculo e, rapidamente, buscavam uma nova solução e assim novos conhecimentos eram adquiridos.

É evidente que a metodologia também apresenta suas desvantagens, a cobrança por parte dos professores é menor, uma vez que a avaliação não passa mais a ser realizados por meio de provas. Também, os alunos, devido à facilidade de acesso a informação que hoje possuem disponíveis na internet, deixam de buscar por fontes mais confiáveis. Para os alunos mais introspectivos, a metodologia também é um desafio uma vez que o trabalho em grupo é contínuo.

De todas as formas, em ambas as aplicações do projeto com os alunos ingressantes os resultados foram satisfatórios. Inicialmente, a dificuldade em adaptar-se ao método era facilmente percebida através dos relatórios de acompanhamento, mas que foi compensada com o desenvolvimento dos participantes no final do semestre. Sabemos que não há uma verdadeira receita correta para ensinar. É uma questão de realidade e da capacidade de perceber e aproveitar as oportunidades de cada metodologia.

\section{REFERÊNCIAS}

[1] brasil. Apresentação - PET. Disponível em: http://portal.mec.gov.br/pet. Acesso em: 29 mar. 2019.

[2] Cavalcante, F. P. L.; Embiruçu, M. S.; Aprendizado com base em problemas: como entusiasmar os alunos e reduzir a evasão nos cursos de graduação em engenharia. In: XLI Congresso Brasileiro de Educação em Engenharia, 2013, Porto Alegre. Anais. Gramado, 2013.

[3] Filho, R. L. L. S.; Montejunas, P. R.; Hipólito, O.; Lobo, M. B. C. M. A evasão no ensino superior brasileiro. Cadernos de Pesquisa, São Paulo, v. 37, n. 132, p. 641-659, 2007.

[4] Kuri, Nídia Pavan. Tipos de personalidades e estilos de aprendizagem: Proposições para o ensino de engenharia. 2004. 337 f. Tese (Doutorado em Engenharia de Produção) - Centro de ciências exatas e tecnologia, Universidade Federal de São Carlos, São Carlos, 2004.

[5] Masson, Terezinha J.; Miranda, Leila F.; Munhoz, Antonio H. J.; Castanheira, Ana M. P.; Metodologia de ensino: Aprendizagem Baseada em Projetos (PBL). In: XL Congresso Brasileiro de Educação em Engenharia, 2012. Belém. Anais. Belém, 2012.

[6] nagai, W. A, Izeki, C. A. Relato de experiência com metodologia ativa de aprendizagem em uma disciplina de programação básica com ingressantes dos cursos de Engenharia da Computação, Engenharia de Controle e Automação e Engenharia Elétrica. Revista de Exatas e TECnológicas, Itabira, v.4, n.1, 2013.

[7] Pereira, Mauro C.; Ferreira, Wanderlei M.; Batista, Edson A.; Scampini, Elvézio J.; Falco, Janaina R.; Evitando evasão em cursos de engenharia: um estudo de caso. In: xxxiv Congresso Brasileiro de Educação em Engenharia, 2006, Porto Alegre. Anais. Passo Fundo, 2006.

[8] Ribeiro, L. R. C. Aprendizagem Baseada em Problemas (PBL) na educação em engenharia. Revista de Ensino de Engenharia, São Carlos, v. 27, n.2, p. 23-32, 2008.

[9] Sesoko, Veronica M.; Neto, Octavio M.. Análise de experiências de Problem e Project Based Learning em cursos de engenharia civil. In: XLII Congresso Brasileiro de Educação em Engenharia, 2014, Belo Horizonte. Anais. Juiz de Fora, 2014. 


\section{Capítulo 7}

\section{PBL e inteligência artificial aplicados na inovação da educação à distância}

\section{Ercilia de Stefano}

Nelson Francisco Favilla Ebecken

Resumo: A Educação à Distância (EAD) caracteriza-se pelo estabelecimento de uma comunicação de múltiplas vias, através das inúmeras possibilidades que se disponibiliza para 0 aprendizado em meio às mudanças tecnológicas. EAD supera limites de tempo e de espaço, e principalmente de disponibilidade.

A EAD leva a democratização do acesso ao ensino, e deve primar pela qualidade, dinamismo e estar atualizado com a linguagem do século XXI. Na educação a distância, o aluno é desafiado a pesquisar e entender o conteúdo, de forma a participar da disciplina. Assim, a Educação deixa de ser concebida como mera transferência de informações e passa a ser norteada pela contextualização de conhecimentos pelo aluno. Associando a EAD com o PBL (Problem Based Learning ou Aprendizagem Baseada em Problemas), o aluno aprende a ter autonomia no seu aprendizado.

Através de tecnologias de Inteligência Artificial aliadas a metodologia do PBL, é possível desenvolver ainda mais a inteligência dos alunos, incentivar a inovação, gerenciar de forma efetiva os recursos e promover melhorias contínuas, através de atividades de colaboração e coordenação mais efetivas.

A integração de diferentes tecnologias, metodologias e áreas de conhecimento enriquece e inova no resultado final obtido da EAD, com destaque para a aplicação nas áreas de Engenharia.

Palavras-chave: PBL, Inteligência Artificial, EAD, ensino. 


\section{INTRODUÇÃO}

O ensino caminha em direção a estar cada vez mais centrado no aluno. 0 professor perde o título de autoridade. Abandona-se o processo didático onde o professor apenas transfere unidirecionalmente informações ao aluno. As informações eram simplesmente transmitidas de um para outro, e neste processo, perdiam-se oportunidades de construção do conhecimento por parte do aluno.

Atualmente destaca-se a importância do professor no desenvolvimento psicológico, social e intelectual dos alunos. Os professores estão assumindo o papel de facilitador, e como facilitadores, os professores devem atuar como guias e colaboradores, tornando efetivamente os alunos o centro do ambiente de aprendizagem (REEVES et al., 2008).

Diante deste cenário, o presente artigo irá abordar aprendizagem baseada em problemas (PBL - Problem Based Learning) que é uma metodologia centrada no aluno, que possibilita a aprendizagem sobre diferentes temas através da experiência de resolver um problema. A metodologia PBL não se concentra na resolução de problemas com uma solução pré-definida, mas permite o desenvolvimento de outras habilidades e atributos desejáveis. Isso inclui aquisição de conhecimento, aprimoramento da colaboração em grupo e da comunicação.

A metodologia permite que os alunos desenvolvam habilidades a serem utilizadas em práticas futuras e no mundo real. Muito difundida em diversos cursos, com destaque nas faculdades de Engenharia no Brasil, como: UFF, UnB, UFV, Unifesp, UEL, dentre outras. A metodologia PBL melhora a avaliação crítica, intensifica a revisão da literatura e incentiva a aprendizagem contínua em um ambiente de equipe.

WOOD (2003) define a aprendizagem baseada em problemas como um processo que utiliza questões identificadas dentro de um cenário, para aumentar o conhecimento e a compreensão. 0 currículo baseado na metodologia PBL é desenvolvido para estimular a aprendizagem, permitindo que os alunos vejam a relevância e a aplicação das soluções encontradas em problemas futuros. Mantém elevado o nível de motivação para o aprendizado e mostra a importância de atitudes responsáveis e profissionais, como os valores do trabalho em equipe.

Com o objetivo de atender com qualidade tantos alunos quanto professores, esta pesquisa apresenta a Inteligência Artificial como uma tecnologia que revolucionará a EAD, sugere aplicações, e apresenta resultados que a IA pode trazer à esta modalidade de ensino. E como um segundo diferencial, esta pesquisa sugere a associação da EAD à metodologia do PBL, para tornar ainda mais interativo, personalizado e objetivo o ensino do ponto de vista do aluno.

\section{EAD}

A Educação à Distância, é uma modalidade de educação onde discentes e docentes estão separados espacial e/ou temporalmente, ou seja, não estão fisicamente presentes em um ambiente presencial de ensino-aprendizagem. Atualmente na grande maioria dos casos mediada por tecnologia.

Verifica-se quão importante é a EAD para a democratização do ensino, não apenas como uma política nacional de difusão do conhecimento e da formação profissional e intelectual, mas internacionalmente, universalizando o ensino.

De acordo com o MEC (2015)

"Educação a distância é a modalidade educacional na qual alunos e professores estão separados, física ou temporalmente e, por isso, faz-se necessária a utilização de meios e tecnologias de informação e comunicação. Essa modalidade é regulada por uma legislação específica e pode ser implantada na educação básica (educação de jovens e adultos, educação profissional técnica de nível médio) e na educação superior."

É importante ressaltar que a modalidade de cursos a distância é reconhecida pelo ministério da educação (MEC), e por ele regulamentada, incluindo as formas de avaliação para a liberação e reconhecimento de cursos. 


\subsection{HISTÓRIA DA EAD}

EAD iniciou-se com ensino por correspondência, e foi no final da primeira guerra mundial que surgiram novas iniciativas de EAD em virtude do aumento significativo da demanda social por educação. Com o aperfeiçoamento dos serviços de correio, a agilização dos meios de transporte e, sobretudo, o desenvolvimento tecnológico aplicado ao campo da comunicação e da informação influíram decisivamente nos destinos da educação a distância.

De acordo com ANEAD (2012), em 1922, a antiga união soviética "organizou um sistema de ensino por correspondência que em dois anos passou a atender 350 mil usuários" e a "França criou em 1939 um serviço de ensino por via postal para a clientela de estudantes deslocados pelo êxodo".

Esse foi o ponto de partida decisivo para o sucesso da nova modalidade de ensino. Com a difusão do rádio e seu alcance, a EAD obteve excelentes resultados, tanto nacionais quanto internacionais, tendo sido bastante utilizado na américa latina em programas de educação a distância em países como o Brasil, Colômbia, México, Venezuela, dentre outros.

Ainda de acordo com ANEAD (2012), além das transmissões de rádio, os cursos começaram a incorporar articuladamente e integradamente o áudio e o videocassete complementando o material de base escrito.

Ainda na década de 1970 no Brasil iniciou as transmissões televisivas, e progressivamente foi introduzido o uso do computador e, mais recentemente a tecnologia de multimeios, que combina textos, sons, imagens, assim como mecanismos de geração de caminhos alternativos de aprendizagem (hipertextos, diferentes linguagens) e instrumentos para fixação de aprendizagem com feedback imediato (programas tutoriais informatizados), etc.

\subsection{ATUALIDADE}

Atualmente a EAD abrange praticamente o mundo todo, onde se tem acesso à internet, tanto em países industrializadas quanto em países em desenvolvimento. Novos e mais complexos cursos são desenvolvidos, tanto no âmbito dos sistemas de ensino formal quanto nas áreas de treinamento profissional, nas modalidades paga e gratuita.

O uso do computador como ferramenta educacional, tem se mostrado útil e proveitoso no processo de EAD, e foi o que propiciou sua rápida expansão. A informática torna-se um agente facilitador do ensinoaprendizagem, tanto na aplicação da criação de grandes plataformas Web de ensino, como no desenvolvimento de softwares educativos. Os computadores ampliam as possibilidades de trabalhos colaborativos, interação entre grupos e alunos, etc. (REEVES et al., 2008).

No caso dos softwares educativos, a qualidade do ensino e é tratada na norma ISO/IEC 12119, que foca os requisitos de qualidade de pacotes de software. Os softwares devem apresentar fatores que facilitam a atuação do professor e o aprendizado por parte do aluno.

As principais características normatizadas pela ISO/IEC 12119 são: pedagógicas; facilidade de uso da interface; adaptabilidade; precisão; clareza; modularidade; disponibilidade; estrutura, monitoração e rastreabilidade.

As grandes plataformas Web de EAD tem como principal característica ser multiplataforma, ou seja, pode ser acessado através de qualquer sistema operacional através de um browser. Com a facilidade de acesso à internet, aos smartphones e tablets, o aluno pode acessar em qualquer tempo e lugar seu estudo, tendo total flexibilidade para montar seus horários, dando ao aluno total autonomia sobre seu aprendizado.

A educação baseada em computadores quando se vale de tecnologias baseadas em inteligência artificial reconhece a diferença entre os alunos e personaliza os conteúdos apresentados, adequando-os aos diferentes estilos de aprendizagem (REEVES et al., 2008). Os computadores também podem modificar conteúdos com base nos erros cometidos por um aluno individual (BURTON \& BROWN, 1982) ou recomendar estratégias de ensino adequadas com base no desempenho do(s) aluno(s) (TENNYSON, 1980). 


\section{PBL}

Cada aluno traz a sua própria experiência de vida e de conhecimento para as salas de aula, mas o que se pode observar é que as estratégias tradicionais de ensino pouco fizeram para nivelar as diferenças entre os alunos (REEVES et al., 2008).

Vale recordar que o conhecimento é construído através do processo de negociação social e através da autoavaliação posterior aos entendimentos individuais. A colaboração é importante pois permite aos alunos avaliar seus próprios entendimentos à luz das exibições expressas por outros membros do grupo (SAVERY \& DUFFY, 1995).

Muitas vezes estes pontos de vista alternativos são uma fonte de reflexão e dão sentido a uma nova informação permitindo assim a continuação da aprendizagem (Von GLASERFELD, 1989; SAVERY \& DUFFY, 1995). Portanto, os grupos colaborativos são um mecanismo valioso para enriquecer e construir a compreensão do aluno.

Os trabalhos colaborativos em grupos são uma estratégia de aprendizagem eficaz, uma vez que promovem a interação social, para que em conjunto os alunos alcancem um objetivo unificado, além de apoiar a reflexão e experiências do aluno em um nível individual (COLLIS \& MOONEN, 2001).

Esses trabalhos demonstram níveis mais elevados de desenvolvimento de competências e aprendizagem do que os realizados por alunos do ensino convencional. Em grupos de colaboração, o diálogo é incentivado não só entre os alunos e seus professores, mas também entre os próprios alunos (BRAILSFORD et al., 1997). Essa abordagem leva a níveis mais profundos de compreensão e também motiva intrinsecamente estudantes a persistir na sua tarefa de aprender (RIEBER, 1996).

Na confluência destes autores, encontramos a aprendizagem baseada em problemas (PBL) que consiste em uma metodologia pedagógica centrada no aluno, na qual os alunos aprendem sobre um assunto através da experiência de resolver um problema. A metodologia PBL consiste na criação de pequenos grupos de alunos, onde cada aluno assume um papel dentro do grupo, que pode ser formal ou informal e pode-se optar pela troca cíclica do papel, para todos tenham a experiência de transitar por todas as funções dentro do problema. Ela é focada na reflexão e raciocínio do aluno para construir sua própria aprendizagem.

A metodologia criada na Universidade de Maastricht consiste em sete etapas citadas a seguir: envolver, esclarecer termos, definir problema(s), brainstorming, estruturação e hipótese, objetivos de aprendizagem, estudo e síntese. Em suma, é identificar o que eles já sabem, o que eles precisam saber, e como e onde acessar novas informações que poderão levar à resolução do problema. 0 papel do professor é facilitar o aprendizado apoiando, orientando e monitorando o processo de aprendizagem (SCHMIDT et al., 2011). 0 professor deve desenvolver a confiança dos alunos para enfrentar o problema e encorajá-los, ao mesmo tempo, para aumentar sua compreensão sobre o tema. Esse processo é baseado no construtivismo. As construções para o ensino de PBL são muito diferentes do ensino tradicional em sala de aula ou de palestra e, muitas vezes, requer mais tempo de preparação e recursos para apoiar a aprendizagem em pequenos grupos.

O uso do PBL expandiu-se desde sua introdução inicial em programas de faculdades de medicina, sendo utilizado em outras áreas da ciência da saúde, matemática, direito, educação, economia, negócios, estudos sociais e engenharia (GASSER, 2011). O PBL inclui problemas que podem ser resolvidos de várias formas, e dependendo da identificação inicial do problema, podem ter mais de uma solução.

A vantagem do PBL ser focado no aluno permite uma aprendizagem ativa e uma melhor compreensão e retenção de conhecimento. Também ajuda a desenvolver habilidades para a vida, que podem ser aplicáveis a áreas distintas (WOOD, 2003). PBL pode ser utilizado para aprimorar o conhecimento do conteúdo, mas ao mesmo tempo promove o desenvolvimento da comunicação, resolução de problemas, pensamento crítico, colaboração e habilidades de aprendizagem autodirigidas. Ao aproveitar o intelecto do grupo coletivo, diferentes perspectivas podem oferecer diferentes percepções e soluções para um problema.

O papel do professor no PBL é orientar e desafiar o processo de aprendizagem, em vez de fornecer estritamente o conhecimento elaborado (BARRETT, 2010; DOLMANS et al., 2005). Nesta perspectiva, o feedback e a reflexão sobre o processo de aprendizagem e a dinâmica de grupo são componentes essenciais do PBL. Os estudantes são considerados agentes ativos que se envolvem na construção do conhecimento social. 
O PBL auxilia nos processos de criação de significado e na construção de interpretações pessoais do mundo com base em experiências e interações. Os alunos que aprendem com PBL são melhores para resolver problemas e se suas atitudes em relação à matemática foram melhoradas em comparação com suas colegas em um currículo mais tradicional.

\section{TECNOLOGIAS DE IA APLICÁVEIS À EAD}

Os diferentes recursos da informática trazidos pela IA irão proporcionar mais dinâmica, facilidade de acesso à conteúdos e novas formas de estimular os alunos a quererem aprender, a serem proativos e participativos no processo como um todo.

A natureza do conhecimento humano utiliza a compreensão, análise e síntese de informações para a tomada de decisões inteligentes, sendo que "a informação é um dado analisado e contextualizado", de acordo com REZENDE et al. (2005). O dado é um elemento puro, que pode ser quantificado em um determinado evento, já oconhecimento é "a habilidade de criar um modelo mental que descreva o objeto e indique as ações a implementar".

É importante observar que para a construção do conhecimento o indivíduo realiza comparações e combinações anteriormente apreendidas (hiperconexões) que são dependentes "de nossos valores e nossa experiência e sujeito às leis universalmente aceitas. " (REZENDE et al., 2005), assim como no PBL.

Inteligência Artificial, que para RUSSELL \& NORVIG (2004) é "o estudo de agentes que recebem percepções do ambiente e executam ações. Cada agente implementa uma função que mapeia sequências de percepções em ações (....)". De acordo com SAGE (1990), inteligência artificial "é o desenvolvimento de paradigmas ou algoritmos que requeiram máquinas para realizar tarefas cognitivas, para as quais os humanos são atualmente melhores".

SAGE (1990) define que um sistema de IA deve "ser capaz de fazer três coisas: armazenar conhecimento, aplicar conhecimento armazenado para resolver problemas e adquirir novo conhecimento através da experiência".

REZENDE et al. (2005) define que os sistemas para serem considerados inteligentes devem ter "habilidade para usar conhecimento para desempenhar tarefas ou resolver problemas" e ter "a capacidade para aproveitar associações e inferência para trabalhara com problemas complexos que se assemelham à problemas reais".

0 processamento de linguagem natural (PLN) faz parte da classificação dos sistemas inteligentes, pois utiliza técnicas e metodologias específicas, tais como: aquisição do conhecimento, aprendizado de máquina, lógica fuzzy, mineração de dados e detextos.

O PLN é um ramo da ciência da computação, caracterizado pela interseção da inteligência artificial e linguística. O PLN estuda as interações entre computadores e a linguagem humana (natural) e lida com problemas relacionados à automação da interpretação e da geração da língua humana (STEFANO et al. 2016). Consiste na aplicação de métodos e técnicas que possibilitem ao computador extrair a semântica da linguagem humana expressa em textos e voz. É uma estratégia de modelagem cognitiva. Tem aplicação na recuperação da informação, mineração de texto e reconhecimento de voz.

O grande desafio do PLN é a compreensão da linguagem natural pelos computadores, extraindo significado das entradas de dados no formato de linguagem natural, e a partir disto sintetizar informações e apresentar resultados.

Será a junção da EAD com todos os recursos citados de inteligência artificial que resultará em uma nova modalidade de educação à distância, a EADI, a EAD Inteligente. Uma plataforma EADI tem as funcionalidades clássicas de uma plataforma EAD, acrescida das habilidades de interpretação e compreensão da linguagem humana, com autonomia para conectar informações de forma associativa, e interagir autonomamente com alunos e professores, além de fornecer o suporte necessário para a aplicação do PBL no curso ou disciplina.

Para complementar a autonomia do software de EADI, a utilização de agentes inteligentes completa a infraestrutura da plataforma. Os agentes inteligentes são entidades autônomas, dotadas de uma base de conhecimento e são capazes de interagir com o meio, possibilitando a tomada de decisões que irão auxiliar ou até mesmo substituir o trabalho de um humano. 
Para melhor entender o que é um agente inteligente será melhor olhar para as suas características e propriedades: autonomia; habilidade social; reação; iniciativa; continuidade temporal; orientação a objetivos; mobilidade; submissão; racionalidade; adaptabilidade; e colaboração. Um exemplo do uso de agentes inteligentes nas avaliações e testes on-line, é que o agente possibilita verificar se um aluno está "chutando" ou não uma resposta.

Para finalizar, mais uma técnica pode ser incorporada na criação de plataformas dinâmicas de EADI, a gameficação. A gameficação é a nova tendência para ministrar aulas, treinamentos, cursos ou qualquer outra modalidade de ensino, despertando através de jogos individuais e/ou em equipe a disputa que conduz ao aprendizado de forma lúdica e prazerosa.

Os jogos de computador fornecer elementos de diversão e desafio e incentivam os alunos aprender a resolução de problemas, tomada de decisão e habilidades (KEARSLEY \& SHNEIDERMAN, 1998). Além disso, devido à sua natureza flexível, jogos podem ser aplicados a praticamente qualquer domínio do conhecimento.

Os objetivos da aprendizagem são alcançados através da inclusão de problemas para o avanço de fases dentro do jogo, ponto de interseção com o PBL. Ao resolver estes problemas, os alunos devem ser incentivados a questionar o sistema, internalizar e construir seu próprio conhecimento sobre o material assunto.

Jogos criados para a resolução de problemas interagem com a metodologia do PBL e possibilitam uma mais uma alternativa para alunos em um ambiente de aprendizagem EADI. Jogos também promovem o engajamento criativo, que possibilitam soluções inovadoras, e que consequentemente conduzem os alunos ao empreendedorismo.

Com um enredo apropriado os jogos oferecem aos alunos missões, que propõem a aprendizagem baseada em problemas, que devem ser ancorados a uma tarefa maior ou outro problema. Quanto mais os alunos estão envolvidos com um ambiente de aprendizagem, mais intrinsecamente motivado eles parecem e, portanto, mais propensos a se envolver em comportamentos aprendizagem autorregulada (RIEBER, 1996).

\section{FERRAMENTAS DE SUPORTE A PLATAFORMA EADI}

As tecnologias descritas podem ser aplicadas tanto na plataforma de EADI propriamente dita, como em módulos que trazem ferramentas para dar suporte e aprimorar a qualidade de trabalho e satisfação de professores e alunos. A seguir apresentam-se módulos que agregam valor e conhecimento, e de aplicação dentro da metodologia PBL.

\subsection{SOFTWARE PARA GESTÃO DE PROJETOS}

Gestão de projetos é a aplicação de conhecimentos, habilidades e técnicas na elaboração de atividades relacionadas para atingir um conjunto de objetivos pré- definidos, em um prazo determinado, com certo custo e qualidade, através da mobilização de recursos técnicos e humanos (STEFANO, 2007; STEFANO, 2009).

Uma proposta para este software é que o mesmo dê suporte à:

- $\quad$ Observação e análise: definição do problema, pesquisa, definição de objetivos e restrições;

- Planejar e projetar: geração de opções do problema, desenvolvimento, aprimoramento, detalhamento;

- Construir e executar protótipo e simulá-lo em produção.

- Análise do negócio (financeira);

- Suporte no desenvolvimento do produto.

Dentre as informações fornecidas do problema, objetiva-se com os recursos da inteligência artificial identificar de forma autônoma:

- Oportunidades; 
- Realizar análise do problema (levantamento de informações);

- Sugestões de soluções e de seleção de ideias (triagem).

\subsection{WIKI}

Permite que documentos sejam editados coletivamente com uma linguagem de marcação muito simples e eficaz, através da utilização de um navegador web.

Uma das características da tecnologia Wiki é a facilidade com que as páginas são criadas e alteradas geralmente não existe qualquer revisão antes de as modificações serem aceitas, e a maioria dos Wikis são abertos a todo o público ou pelo menos a todas as pessoas que têm acesso ao servidor Wiki. Manteremos o registro de usuários como obrigatório em todos os Wikis.

O que faz o Wiki tão diferente das outras páginas da internet é o fato de poder ser editado pelos usuários que por ele navegam.

Esta ferramenta integrada a plataforma de ensino, a gestão de projetos, ao GED (visto a seguir), pode ter conteúdos gerados dinamicamente, através da utilização de agentes inteligentes e também compartilhar da rica construção do conhecimento colaborativo.

\subsection{GESTÃO ELETRÔNICA DE DOCUMENTOS (GED)}

Uma ferramenta inteligente de gestão eletrônica de documentos facilmente controla, armazena, compartilha e recupera informações documentos e informações existentes dentro destes documentos. Os sistemas GED permitem aos usuários acessar os documentos de forma ágil e segura.

Documentos formam a grande massa de conhecimentos de uma empresa, de um curso universitário, de uma disciplina, e dos alunos ao longo de um curso. O GED inteligente permite preservar esse patrimônio e organizar eletronicamente documentos e assegurar fácil acesso a informação necessária. 0 GED lida com qualquer formato de documentos digitalizados, links, hiperlinks, e pode se valer de algoritmos inteligentes de busca e localização de conteúdo dentro dos documentos. O GED é de grande valia para preservar o conhecimento tácito, utilizado em conjunto com a ferramenta Wiki.

\subsection{MAPA MENTAL}

É o nome dado para um tipo de diagrama voltado para a gestão de informações, de conhecimento e de capital intelectual. Os mapas mentais simulam o funcionamento do cérebro. Facilitam a compreensão e solução de problemas, e atualmente muito utilizado na memorização e aprendizado. Tem sua aplicação também na criação de manuais, livros e palestras, e muito difundido no design thiking. É uma ferramenta de brainstorming muito útil no auxílio na tomada de decisões estratégicas.

O sistema de diagrama dos mapas mentais funciona como uma representação gráfica das ideias que se organizam em torno de um determinado foco. Os desenhos feitos em um mapa mental partem de um único centro, a partir do qual são irradiadas as informações relacionadas. Pode ser aplicado a qualquer problema, atividade, profissional ou lazer, de modo individual ou em grupo, para planejar qualquer tipo de ação. Tratase de um método para planejamento e registro gráfico cada vez mais usado em todas as áreas de conhecimento humano.

\section{CONSIDERAÇÕES FINAIS}

EAD vem expandido cada vez mais seu campo de atuação, alcance e espaço na formação educacional. As novas tecnologias transformam a EAD em EADI, trazendo funcionalidades cada vez mais cativantes, com conteúdos dinâmicos e personalizados, e permitem a customização de forma autônoma e dinâmica. A inteligência artificial pode ainda analisar padrões de erros e acertos dos alunos, e indicar novas formas e caminhos de apresentação de conteúdo, e inclusive, pode sugerir novos problemas para a aplicação do PBL em novas turmas.

É possível compor soluções utilizando além das tecnologias e metodologias aqui apresentadas, ferramentas de suporte operacional e gerencial. Vale destacar que os sistemas inteligentes "aprendem", e quanto mais informações são acrescentadas à plataforma EADI, mais inteligente ela fica. Por isso, agregar módulos de gestão de projetos, de documentos, Wiki e Mapas Mentais alimenta a plataforma com 
informações, e possibilita a utilização de um data mining para a extração de padrões e informações de extrema relevância para constantes ajustes e aperfeiçoamentos.

A plataforma aqui proposta permite avaliar individualmente alunos ou uma turma de forma autônoma, indicando conteúdos que devem ser reforçados, pontos em aberto dentro do conteúdo do programa do curso ou disciplina, e controlar a leitura de documentos pelos usuários da plataforma EADI. Certamente a EADI associado ao PBL é um ótimo futuro para o ensino convencional, cursos livres e pós-graduação

\section{REFERÊNCIAS}

[1] Anead Associação Nacional de Ensino a Distância. Disponível em http://www.anEad.com.br/viewcade.asp?id_cade=3. Acesso em: 24 jan. 2012.

[2] Barrett, T. The problem- based learning process as finding and being in flow. Innovations in Education and Teaching International. 2010. 47 (2): 165-174. doi:10.1080/14703291003718901.

[3] Brailsford, T. Faff, R. Oliver, B. Research Design Issues in the Estimation of Beta, McGraw-Hill. Series in Advanced Finance. 1997. Vol. 1, (McGraw-Hill: Sydney).

[4] Burton, R. \& Brown, J. S. Inteligent Tutoring Systems. Addison-Wesley, New York.1982. chapter 2.

[5] Collis, B., \& Moonen, J. Flexible learning in a digital world. London: Kogan Page. 2001. Chapter 2, pp. 29-43. Dolmans, D. H. J. M. DE Grave, W. Wolfhagen, I. H. A. P. Van Der

[6] Vleuten, C. P. M. Problem-based learning: Future challenges for educational practice and research. Medical Education. 2005. 39 (7): 732-41. PMID 15960794. doi:10.1111/j.1365-2929.2005.02205.

[7] Gasser, K. W. Five Ideas for 21st Century Math Classrooms. American Secondary Education. 2011. 39 (3): 108-16. Retrieved 16 November 2012.

[8] Hmelo-Silver, Cindy E.; BARROWS, HOWARD S. Goals and Strategies of a Problem-based Learning Facilitator. Interdisciplinary Journal of Problem-based Learning. 2006. 1. doi:10.7771/1541-5015.1004.

[9] Kearsley, G., Shneiderman, B. Engagement Theory: A Framework for Technology-Based Teaching and Learning. Educational Technology. 1998. 38(5), 20-23.

[10] MEC (2015). Disponível em: http://portal.mec.gov.br/index.php?option=com_content\&id=12823:o-quee-educacao- a-distancia\&Itemid=230. Acesso em: 03 jan. 2015. Reeves, S. Zwarenstein, M. Goldman, J. Barr, H. Freeth, D. Hammick,

[11] M. KOPPEL, I. Interprofessional education: effects on professional practice and health care outcomes. Cochrane Database of Systematic Reviews. 2008. Issue 1. Art. No.: CD002213. DOI: 10.1002/14651858.CD002213.pub2. Rezende, S. Sistemas Inteligentes. Fundamentos e aplicações. São Paulo: Manole, 2005.

[12] Rieber, L. P. Seriously considering play: Designing interactive learning environments based on the blending of microworlds, simulations, and games. Educational Technology Research \& Development. 1996. 44(2), 43-58.

[13] Russel, S. Norvig, P. Inteligência Artificial. São Paulo. 2004.

[14] Sage, A. P. Concise Encyclopedia of Information Processing in Systems and Organizations. Nova Iorque: Pergamon, 1990.

[15] Savery, J. R. \& Duffy, T. M. Problem-Based Learning: An instructional model and its constructivist framework. Educational Technology. 1995. Vol. 35 Iss. 5.

[16] Available at: http://works.bepress.com/john_savery/4/. Acesso em:12 jun. 2017.

[17] Schmidt, H. G. Rotgans, J. I. Yew, E. H. J. The process of problem-based learning: What works and why". Medical Education. 2011. 45 (8): 792-806. PMID 21752076. doi:10.1111/j.1365-2923.2011.04035.

[18] Stefano, E. de SEQUEIRA SANTOS, M. P. Balassiano, R. Development of a software for metric studies of transportation engineering journals. Scientometrics. 2016. 109(3), pp.1579-1591.

[19] Stefano, E. Nova metodologia de Gestão de Projetos Científicos. Tese de Doutorado UFRJ - Coppe, Rio de Janeiro. 2009.

[20] Stefano, E., et al. Conews: A collaborative approach to online news stories. In: ICEIS Funchal. Software Agents and Internet Computing. 2007. p. 101-106, 2007.

[21] Straub, D. Gefen, D. Boudreau, M. The ISWorld Quantitative, Positivist Research Methods Website. (Ed) Dennis Galletta. Disponível em: http://www.dstraub.cis.gsu.edu:88/quant. Acesso em: 7 jan. 2015.

[22] Tennyson, R. D. Instructional control strategies and content structure as design variables in concept 
acquisition using computer-based instruction.Journal of Educational Psychology. 1980. 72, 525-532.

[23] Von Glaserfeld, 1989. Cognition, Construction of Knowledge, and Teaching. Synthese 80(1), 121-140 (special issue on education), 1989. 118. Disponível em: https://www.univie.ac.at/constructivism/EvG/papers/118.pdf. Acesso em: 12 jun. 2017.

[24] Walsham, G. Interpreting Information Systems in Organizations, Wiley, Chichester, 1993. IN: Myers, Michael D. "Qualitative research in Information Systems". 2006. Disponível em: http://www.qual.auckland.ac.nz. Acesso em: 14 mai. 2014

[25] Wood D. ABC of learning and teaching in medicine Problem based learning. BMJ. 2003. 326: 328-330. doi:10.1136/bmj.326.7384.328. Retrieved 20 September 2015. 


\section{Capítulo 8}

Um estudo sobre os interesses de alunos de engenharia mecânica na modalidade EAD - estratégias pedagógicas de ensino

Bruna Gonçalves de Souza

Eduardo Costa Estambasse

Rennan Otavio Kanashiro

Resumo : 0 presente trabalho aborda a análise dos interesses de alunos do $4^{\circ}$ ao $7^{0} \underline{0}$ semestre do curso superior de engenharia mecânica na modalidade EaD, discutindo os resultados obtidos a partir de um questionário aplicado aos alunos matriculados nesses semestres. Para esse trabalho, foi utilizada uma metodologia de pesquisa com abordagem quantitativa. A partir dos resultados, foi realizada uma avaliação crítica da disciplina Seminário Interdisciplinar, sugerindo-se uma reestruturação em relação aos conteúdos abordados.

Palavras chaves: Educação a Distância, Engenharia Mecânica, EaD. 


\section{INTRODUÇÃO}

O curso de Engenharia Mecânica é do tipo bacharelado e tem duração média de 5 anos. Durante esse período, o estudante conta com uma carga intensa de disciplinas que abordam assuntos como controle e automação de processos industriais, processos de fabricação, materiais, manutenção e sistemas térmicos. Com uma formação abrangente, o engenheiro mecânico pode atuar em diversos campos, como em projetos de sistemas mecânicos e térmicos, desempenho de funções técnicas, produção e de controle de qualidade, análise e seleção de materiais, controle e manutenção técnica, fiscalização e execução de instalações mecânicas, termodinâmicas e eletromecânicas. Além disso, o profissional é capaz de liderar equipes multidisciplinares ou atuar como empreendedor.

0 curso é oferecido nas modalidades presencial e semipresencial (EaD), sendo que ao optar por cursar engenharia mecânica a distância, o aluno poderá encontrar dificuldades em relação à frequência às aulas teóricas ou práticas, o que pode levar ao trancamento ou abandono do curso. Essa realidade de ensino requer estratégias pedagógicas, sendo fundamental identificar alternativas que possam atrair a atenção do aluno e, com isso, levá-lo ao engajamento.

Nesse sentido, a grade de engenharia mecânica do grupo Kroton Educacional, base de investigação, oferece o curso na modalidade a distância e conta com uma disciplina denominada Seminário Interdisciplinar, a qual tem como mote a apresentação de conteúdos transversais aos propostos pelas demais disciplinas cursadas durante cada semestre vigente. Os temas trabalhados têm por foco elevar o conhecimento científico do aluno, sendo essa disciplina uma estratégia de aprendizagem, que tem o intuito de levar o aluno a conhecer e, consequentemente, pensar de forma crítica sobre um determinado tema, com foco em seu crescimento intelectual, bem como o desenvolvimento de competências. Esta disciplina é dividida em quatro encontros, preconizando frequência semanal, sendo uma parte da avaliação feita com base em um sistema virtual com questões elaboradas pelos docentes responsáveis pelas disciplinas do semestre. A outra parte da avaliação é relacionada à atividade Produção Textual em Grupo, que deve ser desenvolvida de forma escrita e finalizada com uma apresentação oral, realizada pelos alunos.

\section{OBJETIVOS}

Esse trabalho teve o objetivo de conhecer os interesses de alunos matriculados nas turmas do $4^{\circ}$ ao $7^{\circ}$ o semestre de engenharia mecânica na modalidade EaD de uma instituição de ensino superior privada, a fim de avaliar de forma crítica a estrutura atual da disciplina Seminário Interdisciplinar e direcionar os professores responsáveis pela disciplina no preparo de conteúdo personalizado e, assim, otimizar o aprendizado discente.

\section{REFERENCIAL TEÓRICO}

A modalidade de ensino a distância (EaD) tem encontrado cada vez mais espaço nos cursos de nível superior, despertando questionamentos quanto a sua definição e forma de aplicação, a fim de otimizar a assimilação de conteúdo. 0 ensino a distância requer uma mudança de postura nos docentes e alunos, que devem possuir um perfil ativo e responsável em meio a esse contexto educacional. Além disso, as instituições adeptas dessa modalidade de ensino precisam se adequar a esse modelo de formação, buscando estratégias inerentes a essa realidade.

No Brasil, a modalidade EaD foi regulamentada pelo Decreto no 5.622 de 2005, do Ministério da Educação, que, por sua vez, regulamenta o Art. 80 da Lei de Diretrizes e Bases da Educação Nacional, que diz: "O poder público incentivará o desenvolvimento e a veiculação de programas de ensino a distância, em todos os níveis e modalidades de ensino, e de educação continuada." Nesse artigo, é notável a preocupação do governo em propiciar incentivos para as instituições que mostrem interesse em ofertar cursos na modalidade a distância.

Desde o surgimento do EaD, pesquisadores têm se questionamentos a respeito da sua correta definição, sendo a maioria de caráter descritivo, com base no ensino convencional, destacando a distância entre professor e aluno e o uso das mídias. Os conceitos evoluíram em relação aos processos de comunicação, com o surgimento de novas tecnologias facilmente empregadas, "quando os modelos educacionais identificam a importância da interação entre os pares para a aprendizagem e a EaD passa a ter mais possibilidades tecnológicas para efetivar essa interação." (LANDIM et al., 2018). 
Ao optar por um curso EaD, o aluno pode definir o horário e local mais adequados à sua realidade para se dedicar aos estudos, de acordo com seu estilo e ritmo de aprendizado. Atrelado a isso, o aluno pode escolher entre os materiais disponibilizados em seu ambiente virtual de aprendizagem, que por sua vez, tem por mote facilitar a interação entre o conteúdo e a didática que promovam a aprendizagem autônoma. Quanto à forma de aprendizagem, aluno age e aprende quando se sente desafiado, ao sentir alguma necessidade, quando está interessado, intrigado ou disposto, ou seja, quando há algum desequilíbrio cognitivo momentâneo entre o meio que o cerca e o seu organismo (SCHERER; BRITO, 2014).

\section{PROCEDIMENTOS METODOLÓGICOS}

Para o levantamento dos dados foi utilizado um questionário online, criado a partir da ferramenta Google Forms. Esse questionário foi disponibilizado aos alunos do $4^{\text {o }}$ ao $7^{\text {oo }}$ semestre do curso de engenharia mecânica EaD de uma instituição de ensino superior privada, para que os mesmos pudessem responder a algumas questões, de forma anônima. As questões foram de múltipla escolha, lista suspensa, caixa de seleção e, até mesmo, contendo grade de múltipla escolha e caixa de seleção, que foram utilizadas para verificar o nível de satisfação do aluno em relação ao andamento do curso, assim como em relação à sua realidade de vida.

Na Figura 1 são apresentados alguns exemplos de questões aplicadas no questionário.

(a) Múltipla escolha

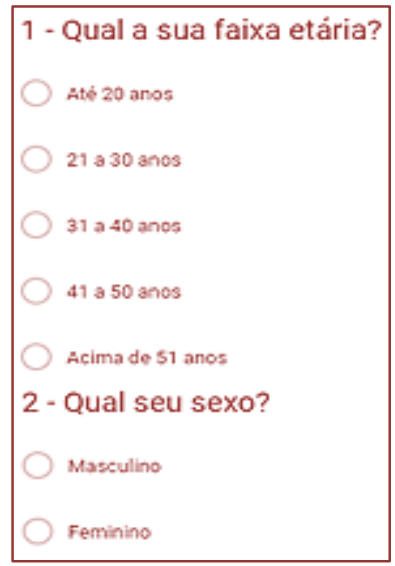

Figura 1 - Exemplos de questões aplicadas.

(b) Caixa de seleção.

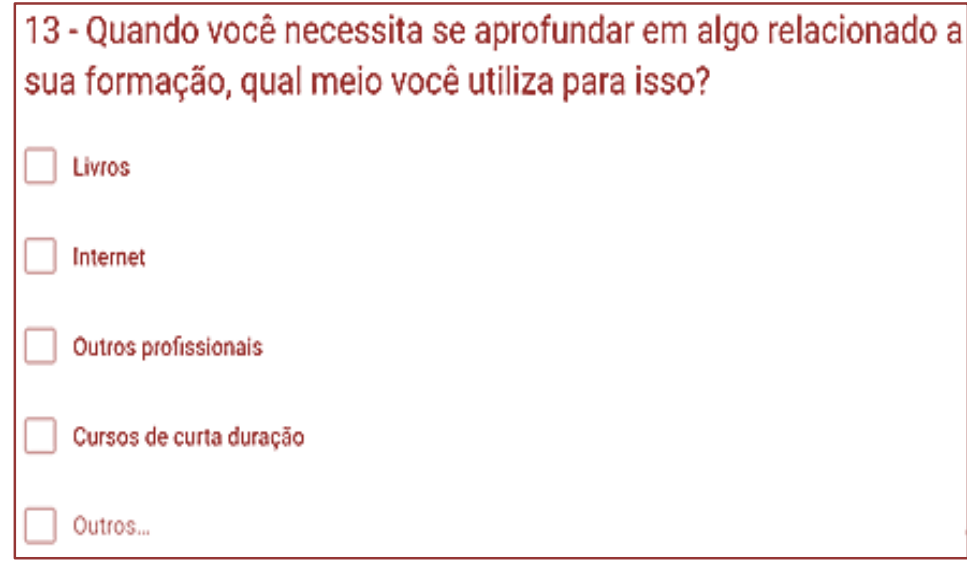

(c) Grade de múltipla escolha.

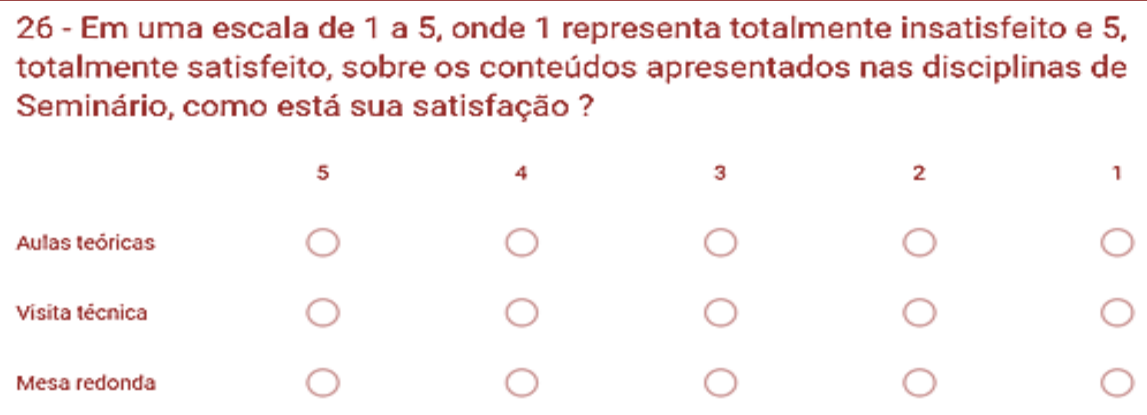

Fonte: os autores.

\section{APRESENTAÇÃO E DISCUSSÃO DOS RESULTADOS}

Após a disponibilização do questionário, foi obtido um total de 90 respostas válidas, das quais $87 \%$ foram do sexo masculino e $13 \%$ do feminino, sendo predominante a faixa etária entre 21 e 40 anos.

Como era o esperado para a realidade EaD, a maioria dos alunos está trabalhando atualmente (92\%), sendo que quando questionados sobre a maior dificuldade encontrada durante o curso, 58\% relataram a necessidade de conciliar as atividades do trabalho e estudos, de acordo com a Figura 2b. Além disso, 28\% dos alunos esperavam que o nível de dificuldade do curso fosse inferior ao encontrado (Figura 2a). Apesar 
da flexibilidade apreciada, o ensino superior EaD também têm datas para entrega de trabalhos e realização de provas, sendo necessário grande dedicação e atenção aos prazos, assim como em qualquer graduação.

Figura 2 - Expectativa em relação a dificuldade na modalidade EaD (a) e dificuldades encontradas durante o curso (b).

(a)

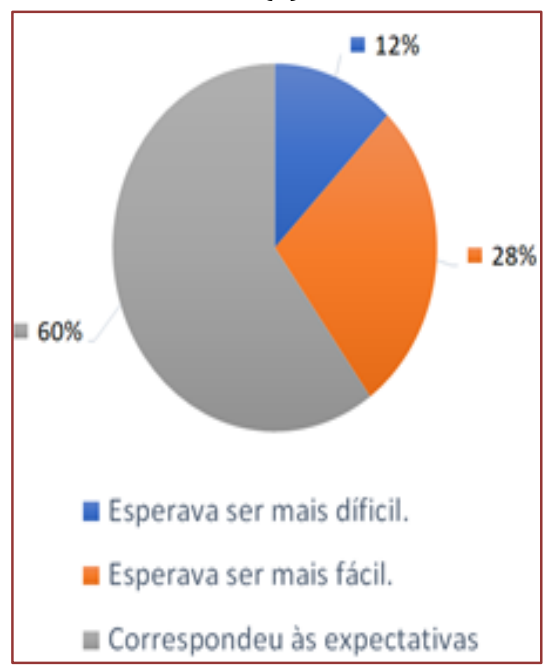

(b)

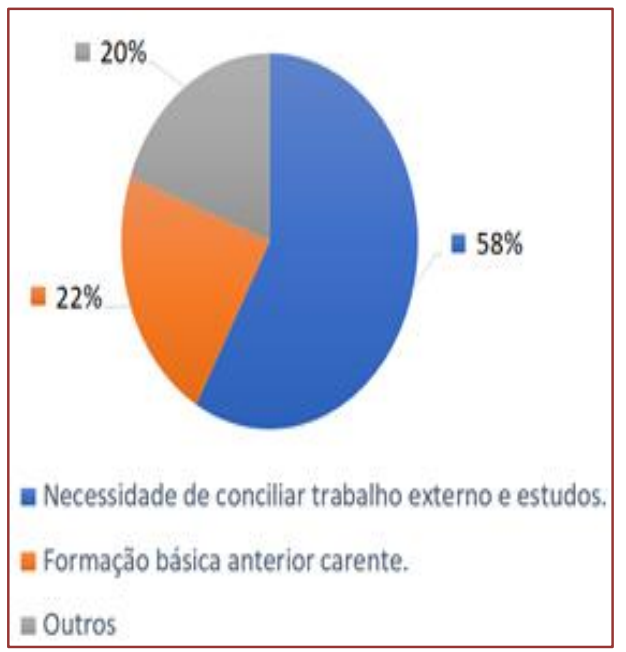

Fonte - Os autores.

Além disso, o deslocamento do aluno até a sua Instituição de Ensino Superior (IES) para participar das atividades presenciais (Figura 3a), pode demandar muito do seu tempo, o que reduz o tempo disponível para estudo. Com uma quantidade considerável de atividades práticas, o curso de Engenharia Mecânica $\mathrm{EaD}$ exige a presença do aluno no polo de apoio com uma certa frequência. Apesar da maioria utilizar veículo próprio (carro ou moto), 14\% dos alunos dependem de meio de transporte público, como pode ser observado na Figura $3 \mathrm{~b}$.

Figura 3 - Distância (a) e meio de transporte utilizado até a IES (b).

(a)

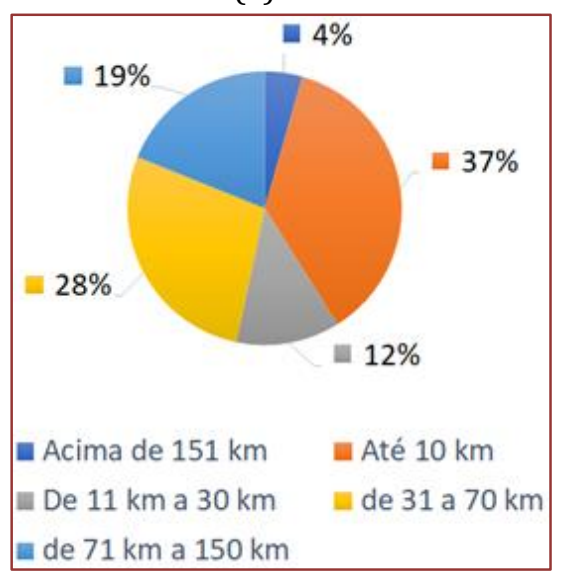

(b)

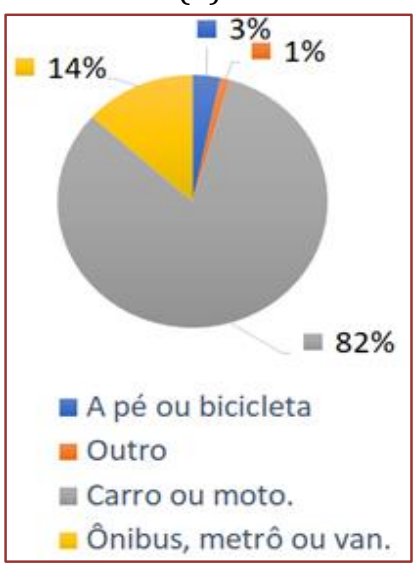

Fonte - Os autores. 
É interessante ressaltar que 32\% dos alunos estão cursando a sua segunda graduação, o que pode resultar em um grau de exigência elevado em relação aos conteúdos e à forma de apresentação dos mesmos, uma vez que esses alunos já compreendem melhor a estrutura de um ensino superior e seus desafios e, buscam um melhor aproveitamento de seu tempo de estudo e aprendizado. Somado a isso, visto que a maioria dos alunos tem pouco tempo disponível para se dedicar aos estudos (Figura 4), a otimização das estratégias de ensino é essencial, a fim de despertar o interesse do aluno e aumentar o seu progresso.

Figura 4 - Tempo semanal dedicado aos estudos em casa.

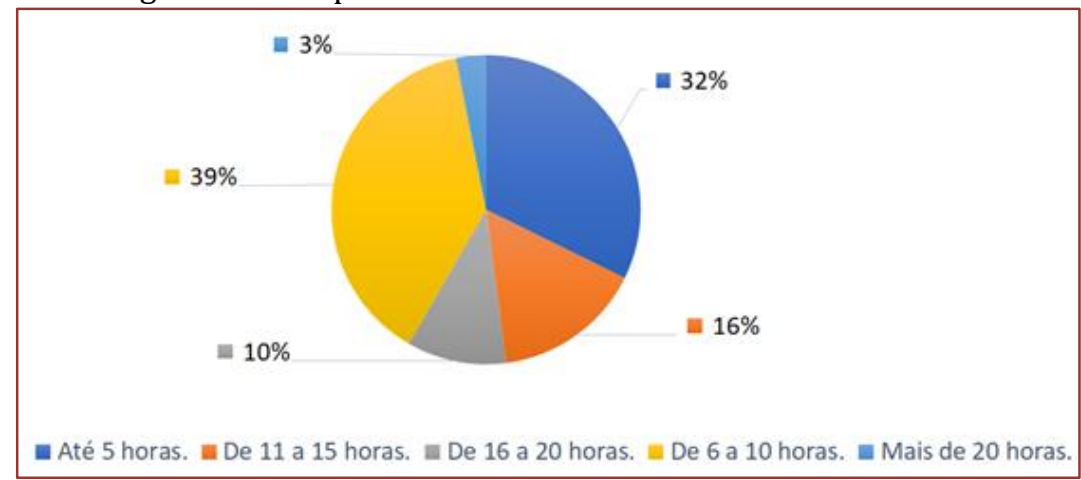

Fonte - Os autores.

Dentre os alunos que estão trabalhando atualmente, $69 \%$ trabalham em alguma área relacionada à engenharia, sendo a maior parcela na área de manutenção, conforme Figura 5a. Por consequência, a área de interesse que mais se destaca é também a de manutenção (Figura 5b). Esse resultado revela um possível tema a ser abordado com maior enfoque na disciplina Seminário Interdisciplinar, indo de encontro ao interesse do aluno.

Figura 5 - Área de atuação (a) e área de interesse (b).

(a)

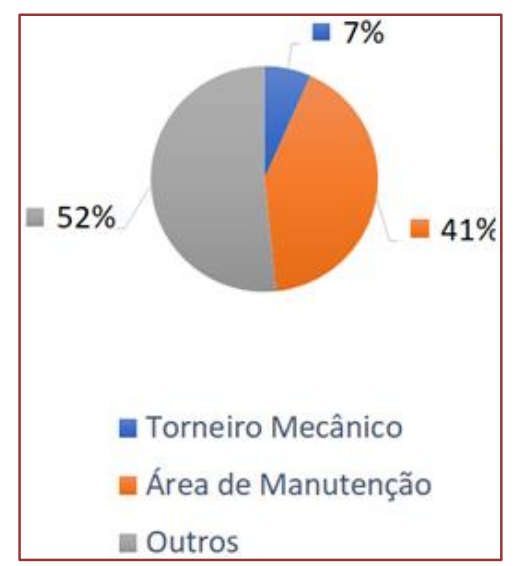

(b)

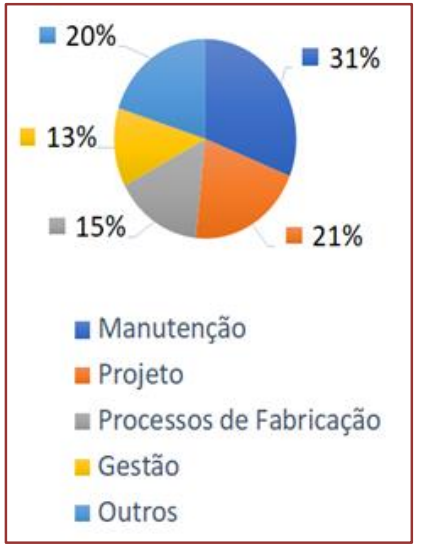

Fonte - Os autores.

A disciplina Seminário Interdisciplinar não possui uma estrutura fixa, uma vez que os temas podem ser trabalhados de diferentes maneiras, sendo de forma mais usual por meio de exposição do conteúdo através de teleaulas teóricas, apresentação de visitas técnicas realizadas e mesas redondas entre profissionais e docentes da área de engenharia mecânica. Em geral, os alunos demonstraram um interesse maior pelas teleaulas teóricas, como representado na Figura 6, de acordo com o nível de satisfação em uma escala de 1 a 5 , onde 1 representa totalmente insatisfeito e 5 , totalmente satisfeito. 
Figura 6 - Nível de satisfação em relação aos conteúdos apresentados na disciplina Seminário Interdisciplinar.

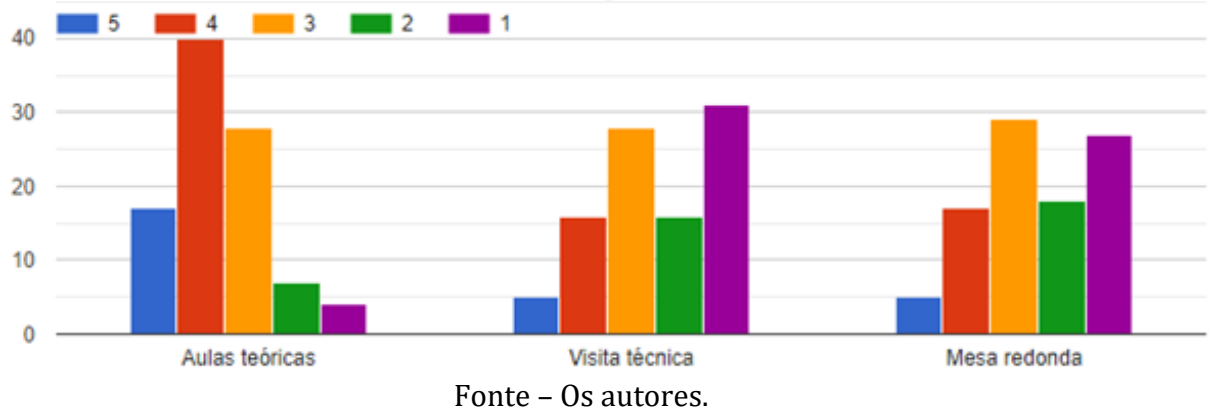

Ao serem questionados sobre sugestões em relação à estrutura dessa disciplina, em sua maioria, os alunos responderam que gostariam de um contato maior dos temas com a realidade da profissão de engenharia mecânica, além de aplicações práticas relacionadas às disciplinas do semestre em andamento.

Dentre os diversos setores ou áreas de atuação do engenheiro mecânico, verificou-se, ao decorrer do trabalho, que os alunos demonstram um maior interesse pelos processos da indústria metalúrgica, setor no qual o engenheiro realiza projetos, bem como atua nos meios de produção, além do fornecimento de recursos e suprimentos. Isso se deve ao fato de que a maioria dos alunos que estão trabalhando, atuem nessa área.

Tendo em vista que a maioria dos alunos preferem a exposição do conteúdo através de teleaulas teóricas, ao mesmo tempo em que gostariam de aplicações práticas em segmentos compatíveis com a formação obtida no curso, uma alternativa poderia ser a apresentação técnica de diferentes segmentos industriais metalúrgicos e, na sequência, uma explanação teórica sobre o que foi apresentado, unindo assim, a teoria e a prática.

\section{CONSIDERAÇÕES FINAIS}

Após a análise dos resultados obtidos a partir da aplicação do questionário, verifica-se que os objetivos do trabalho foram alcançados, uma vez que foi possível identificar temas de interesse do aluno, como por exemplo a área de atuação de manutenção, que será considerado como um tópico de discussão relevante para o preparo de teleaulas futuras para a disciplina Seminário Interdisciplinar.

Dentre as respostas obtidas, em uma questão a respeito da forma de acesso à instituição de ensino, um comentário de uma aluna - na alternativa "Outros" - merece ser destacado: "Como trabalho e fico alojada pela empresa em outra cidade (Acará), dependo de carona que pego na beira da estrada, no entanto meu acesso dificultou devido à quebra da ponte da Alça Viária (Rio moju).”. Esse relato serviu de inspiração e motivação para a realização de outras pesquisas de satisfação, semelhantes a essa, buscando cada vez mais otimizar e possibilitar um aprendizado satisfatório ao aluno.

Como sugestão de estudos futuros para complementação do assunto, propomos a aplicação de um questionário similar a esse utilizado, ao final de cada semestre, a fim de levantar sugestões para temas a serem abordados na disciplina Seminário Interdisciplinar, pensando no semestre seguinte.

\section{REFERENCIAS}

[1] Becker, Fernando. Da ação à operação: o caminho da aprendizagem em J. Piaget e P. Freire. 2. ed. Rio de Janeiro: DP\&A, 1997.

[2] Landim, F. P.; Ota, M. A.; de Carvalho, J. G. as fases da gestão de projetos aplicadas à produção ágil de conteúdos educacionais online. p. 10, 2018.

[3] Scaramuzza, B. et al. Projeto de Extensão na Modalidade EaD: "Startups: ferramentas para o desenvolvimento de negócios inovadores com o uso de tecnologias”. (Associação Brasileira de Educação a Distância, Ed.) Apresentações Trabalhos Científicos. Anais... In: 24ํㅡㄹ CIAED Congresso Internacional abed de educação a distância. Associação Brasileira de Educação a Distância, 7 out. 2018. Disponível em: <http://www.abed.org.br/congresso2018/anais/trabalhos/8319.pdf>. Acesso em: 15 abr. 2019

[4] Scherer, S.; Brito, G. DA S. Educação a distância: possibilidades e desafios para a aprendizagem cooperativa em ambientes virtuais de aprendizagem. Educar em Revista, n. spe4, p. 53-77, 2014. 


\section{Capítulo 9}

\section{Educação Presencial x Educação a Distância em}

cursos de engenharia civil: Análises e reflexões sobre cargas horárias

\section{Jesimiel Pinheiro Cavalcante}

Eliedson Rafael de Carvalho

Juliana Lira Brito

Mallena Soares da Silva

Amanda Thais Passos Cordeiro Cavalcante

Resumo: 0 presente artigo busca realizar uma análise comparativa entre a matriz curricular de um curso de graduação de engenharia civil na modalidade presencial e um na modalidade Ensino a Distância (EaD), em termos de carga horária. As duas instituições atuam na região agreste do estado de Alagoas, distando cerca de $40 \mathrm{~km}$ entre as cidades. 0 setor da construção civil apresenta um relevante papel para 0 desenvolvimento econômico e social, por isso, é fundamental buscar a melhoria constante na formação dos profissionais da engenharia civil. A pesquisa consistiu basicamente, na coleta de dados referente à carga horária utilizada nos componentes da matriz curricular em cursos de engenharia civil de duas instituições de ensino que atuam no interior de Alagoas. Os cursos de engenharia civil escolhidos para análise foram classificados em: CURSO A - público e presencial e CURSO B - Privado e EaD. Os componentes foram divididos por grupos, onde a carga horária dos componentes curriculares foram levantadas e comparadas para cada modalidade. Os resultados demonstram diferenças significativas como: disciplinas da área de estrutura, onde o CURSO A apresentou um aumento significativo de horas em relação ao curso da CURSO B, cerca de 65,00\% de CH. As disciplinas de Instalações Prediais, Técnicas Construtivas, e Geologia apresentaram diferença de CH do CURSO A superior ao CURSO B de 33\%, 20\% e 50\%. A carga horária total do CURSO A é 10,05\% maior que a do CURSO B. Por fim, o artigo exerce um papel fundamental para a produção de conhecimento acerca da educação em engenharia civil, uma vez que fortalece as discussões sobre as matrizes curriculares, bem como a formação profissional.

Palavras-chave: Engenharia civil. Currículo. Educação presencial. Educação a distância. 


\section{INTRODUÇÃO}

O setor da construção civil apresenta um relevante papel para o desenvolvimento econômico e social do Brasil. Nesse contexto, Casale (2013), afirma que formar profissionais competentes e em condições para corresponder às demandas da sociedade é uma tarefa que tem exigido cada vez mais das instituições que ofertam cursos de engenharia. Por esse motivo, é fundamental buscar a melhoria constante da formação e qualificação dos profissionais envolvidos em todos os campos de atuação da engenharia civil.

Apesar da relevância do setor, dados apresentados pela Associação Brasileira de Educação em Engenharia - ABENGE (2018), mostram que, em relação ao número de engenheiros por habitante, o Brasil ocupa uma das piores posições no ranking da Organização para a Cooperação e Desenvolvimento Econômico - OCDE. Para efeito de comparação, a ABENGE revela que em 2014:

[...] enquanto a Coreia, a Rússia, a Finlândia e a Áustria contavam com mais de 20 engenheiros para cada 10 mil habitantes, e países como Portugal e Chile dispunham de cerca de 16, o Brasil registrava somente 4,8 graduados em Engenharia para o mesmo universo de pessoas (ABENGE, 2018, p. 1).

No entanto, a educação em engenharia civil tem passado por um processo de expansão no nosso país nos últimos anos, aumentando tanto o número de matriculados quanto concluintes na modalidade presencial e ultimamente com o advento do Ensino a Distância. De acordo com ABENGE (2019), cerca de 100 mil bacharéis graduaram-se em cursos presenciais e à distância somente em 2016. Esse fato revela a necessidade da elaboração constante de estudos que possam contribuir para a construção do conhecimento referente à qualidade da formação dos novos profissionais recém-graduados.

A Resolução 2 CNE/CES, de 24 de Abril de 2019 que instituiu as Diretrizes Curriculares Nacionais dos Cursos de Graduação em Engenharia (DCNCGE), representa, sem dúvida, um grande avanço para a educação em Engenharia Civil. Como mostra a Resolução, as DCNCGE mantêm a centralidade das competências e das habilidades para a formação de um engenheiro:

[...] ter visão holística e humanista, ser crítico, reflexivo, criativo, cooperativo e ético e com forte formação técnica; estar apto a pesquisar, desenvolver, adaptar e utilizar novas tecnologias, com atuação inovadora e empreendedora; ser capaz de reconhecer as necessidades dos usuários, formular, analisar e resolver, de forma criativa, os problemas de Engenharia; adotar perspectivas multidisciplinares e transdisciplinares em sua prática; considerar os aspectos globais, políticos, econômicos, sociais, ambientais, culturais e de segurança e saúde no trabalho; atuar com isenção e comprometimento com a responsabilidade social e com o desenvolvimento sustentável. (CNE/CES no 021, 2019, p. 1).

De acordo com Souza et al. (2015), apesar da existência das DCNCGE, suas implicações e seus alcances não são totalmente precisos e nem o seu entendimento é único. Ainda, as DCNCGE demonstram que as Instituições de Ensino Superior (IES) têm autonomia e flexibilidade na elaboração de seus projetos pedagógicos. Desse modo, cada IES pode adotar sua própria Matriz Curricular para o Curso de Engenharia, com a carga horária desejada por disciplina. De fato, essa liberdade acaba gerando uma série de questionamentos acerca de como as diferenças nas matrizes curriculares podem ou não interferir na formação do profissional de engenharia civil.

Como em diversas outras IES na área de engenharia, tal superlotação em disciplinas do ciclo básico é um problema frequente, ocorrendo devido ao alto índice de retenção nas disciplinas citadas anteriormente. Entre os diversos efeitos da superlotação, estão professores sobrecarregados, alunos desestimulados e a falta de estrutura (VILELA; LIMA; VILELA, 2016).

Este artigo busca realizar uma análise comparativa entre a matriz curricular de um curso de graduação de engenharia civil na modalidade presencial e na modalidade EaD, em termos de carga horária, com o intuito de levantar dados que permitam refletir acerca da formação ofertada pelos cursos escolhidos.

Para isso, foram escolhidos dois cursos de Engenharia Civil em cidades que distam cerca de $40 \mathrm{~km}$ e atendem cerca de 50 cidades em seus entornos, sendo um na modalidade presencial e o outro EaD, ambos com funcionamento em instituições no interior de Alagoas. O levantamento de dados para análise comparativa foi realizado a partir dos projetos pedagógicos que ambas instituições disponibilizam em suas plataformas online. 


\section{PANORAMA DA OFERTA DO CURSO DE ENGENHARIA CIVIL}

De acordo com o parecer $n^{\circ} 1 / 2019$ da ABENGE (2019), foi possível se verificar a maior expansão em termos de número de cursos de engenharia e de áreas de abrangência, após a publicação da resolução do CNE/CES № 11/2002. Nesse mesmo parecer, a ABENGE revela que:

Considerando o número de cursos nas modalidades presencial e EAD no final de 2001 e no final de 2018, verifica-se que houve um crescimento de $278 \%$ no setor público e $1.060 \%$ no setor privado, registrando-se um crescimento total de 692\% no número de cursos (ABENGE, 2019, p. 10).

De maneira geral, o gráfico1 que apresenta a quantidade de cursos de cursos das principais habilitações de engenharia, tanto em instituições públicas quanto privadas, nas modalidades presencial e à distância, no final de 2018.

Gráfico 1 - Número de Cursos de Engenharia por Habilitação

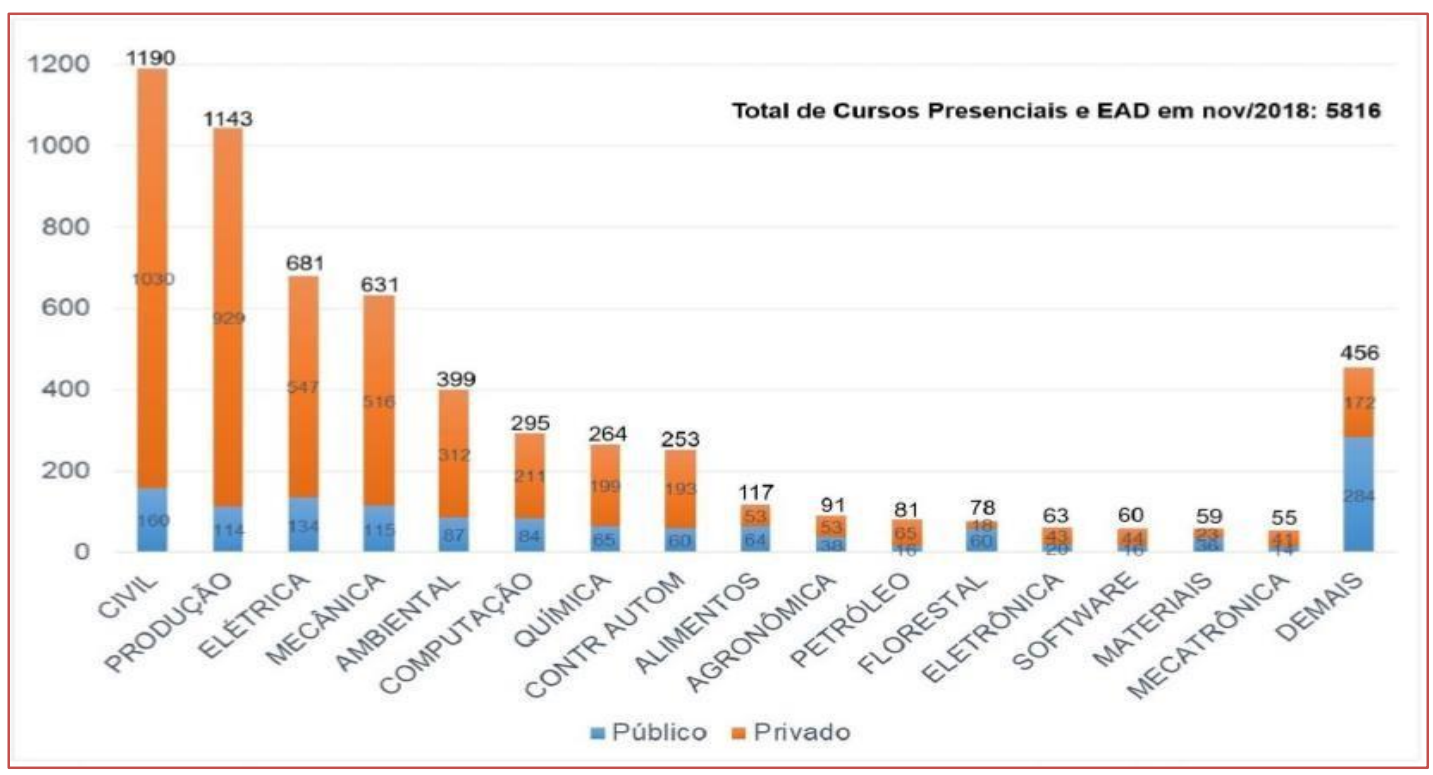

Fonte: ABENGE, 2019

O gráfico 1 revela que dentre os 5816 cursos de engenharia, o número de cursos de engenharia civil é de cerca de $21 \%$ do total, envolvendo tanto público quanto privado nas modalidades EaD e presencial.

Segundo a Sinopse Estatística da Educação Superior 2017 (INEP, 2018), no final de 2018, já existiam 290 cursos de engenharia na modalidade EAD em funcionamento ofertadas por 91 IES. Em seu parecer, a ABENGE (2019) apresenta o gráfico 2 que traz as quantidades de cursos de engenharia EaD distribuídos de acordo com as habilitações. 
Gráfico 2 - Número de Cursos de Engenharia EaD por Habilitação

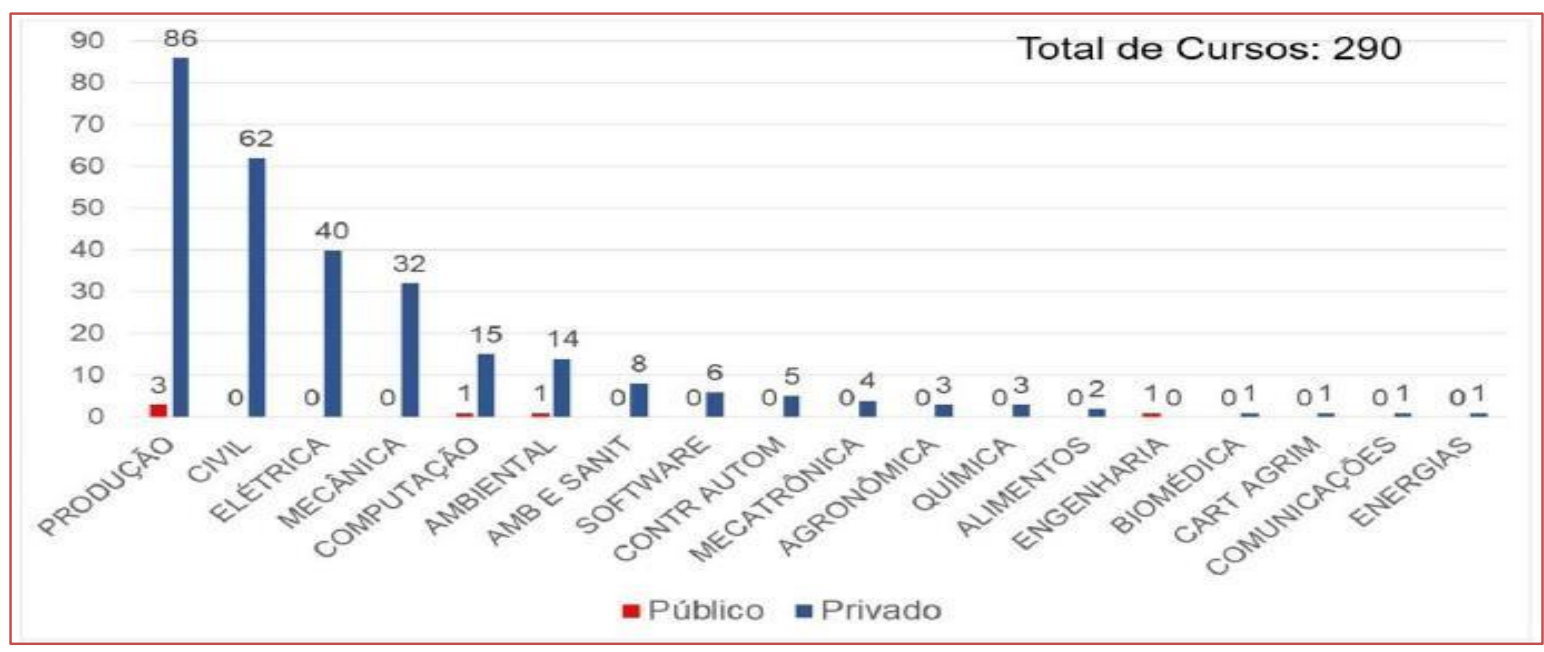

Fonte: ABENGE, 2019

Algo que chama atenção nesses dados, é que apesar de representar menos de $5 \%$ do total de cursos para ambas as modalidades, os cursos EaD já oferecem cerca de $40 \%$ de todas as vagas para engenharia (ABENGE, 2019).

\section{MATERIAIS E MÉTODOS}

Esta pesquisa consistiu, basicamente, na coleta de dados referente à carga horária empregada nos componentes da matriz curricular do curso de engenharia civil de duas instituições de ensino que atuam no interior de Alagoas. Os nomes das instituições de oferta dos cursos foram substituídos por CURSO A e CURSO B por questões de sigilo.

Os procedimentos da pesquisa podem ser divididos nas seguintes etapas: revisão da literatura, escolha dos cursos a serem analisados, coleta, classificação e análise quantitativa dos dados.

\subsection{CURSOS DE ENGENHARIA CIVIL}

CURSO A, curso público presencial de turno integral com aulas todos os dias da semana e carga horária total de 4314horas. 0 curso é ofertado desde o primeiro semestre 2013. A estruturação do curso conta com um mínimo de 71 disciplinas teóricas e práticas (68 obrigatórias e 3 optativas) distribuídas em 10 semestres. Além disso, são exigidas no mínimo $160 \mathrm{~h}$ estágio supervisionado, $100 \mathrm{~h}$ de atividades complementares e trabalho de conclusão de curso.

CURSO B, curso privado na modalidade educação à distância com currículo implantado desde o primeiro semestre de 2015 e carga horária total de 3920 horas. Aulas no polo uma vez por semana, no turno noturno e as aulas práticas são realizadas em mais um encontro na semana. Distribuídas dentro dos 10 semestres, as horas de atividades relativas aos conteúdos curriculares estão organizadas em 65 disciplinas teóricas e práticas (64 obrigatórias e 1 optativa), bem como em $200 \mathrm{~h}$ de estágio supervisionado e $100 \mathrm{~h}$ de atividades complementares e trabalho de conclusão de curso.

\subsection{COLETA DE DADOS}

Os dados, referentes às cargas horárias presentes nas matrizes curriculares, foram coletados a partir dos projetos pedagógicos de ambos os cursos, disponibilizados em seus respectivos sites.

\subsection{CLASSIFICAÇÃO E ANÁLISE DOS DADOS}

Para uma análise mais significativa e organizada, os dados foram classificados em grupos. As cargas horárias para cada grupo de componentes curriculares foram levantadas, em seguida, comparadas para 
cada modalidade e, essas comparações foram representadas em gráficos. Os dados foram divididos nos seguintes grupos:

- Carga horária total (mínima);

- Carga horária optativas;

- Carga horária do núcleo básico;

- Carga horária das disciplinas práticas;

- Carga horária das disciplinas da área estruturas;

- Carga horária das disciplinas da área instalações prediais;

- Carga horária das disciplinas da área técnicas construtivas;

- Carga horária das disciplinas da área geotecnia;

\section{RESULTADOS E DISCUSSÕES}

A primeira parte da análise pode ser vista no gráfico 3 que apresenta o comparativo entre as cargas horárias $(\mathrm{CH})$ totais dos dois cursos apresentadas em seus respectivos projetos pedagógicos. Essa $\mathrm{CH}-$ Total é formada pelos componentes obrigatórios, a carga horária mínima de disciplinas optativas, carga horário mínima de estágio e atividades complementares.

Gráfico 3 - Comparativo de CH - Total mínima

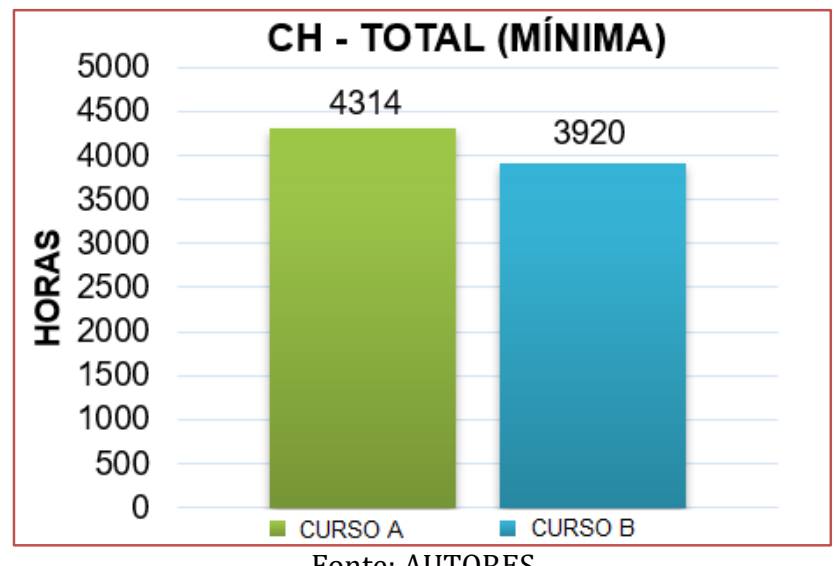

Fonte: AUTORES

Com 4.314 horas, o CURSO A apresenta uma $\mathrm{CH}$ total 10,05\% maior que a do CURSO B. Ressaltando que o curso do CURSO A é presencial, o que exige um controle muito maior de como essa carga horária está sendo ofertada, em relação a cursos EaD, uma vez que na modalidade à distância a carga horária efetiva para disciplina depende muito mais da dedicação do estudante que pode ou não cumprir o mínimo de horas destinado pelo programa do curso. Os dois cursos atendem a Resolução № 2, DE 18 de Junho DE 2007 que estabelece um mínimo de 3600 horas.

A CH das disciplinas optativas do CURSO A é de 198 horas, enquanto do CURSO B é de 60 horas, desta forma o CURSO B oferta 30\% da CH das disciplinas optativas em relação ao CURSO A.

Os resultados obtidos para $\mathrm{CH}$ das disciplinas do núcleo básico encontram-se no gráfico 4. O CURSO A apresenta uma CH de 1800 horas, $7 \%$ a mais que o CURSO B que apresenta 1680 horas. 
Gráfico 4 - Comparativo de CH - Núcleo Básico

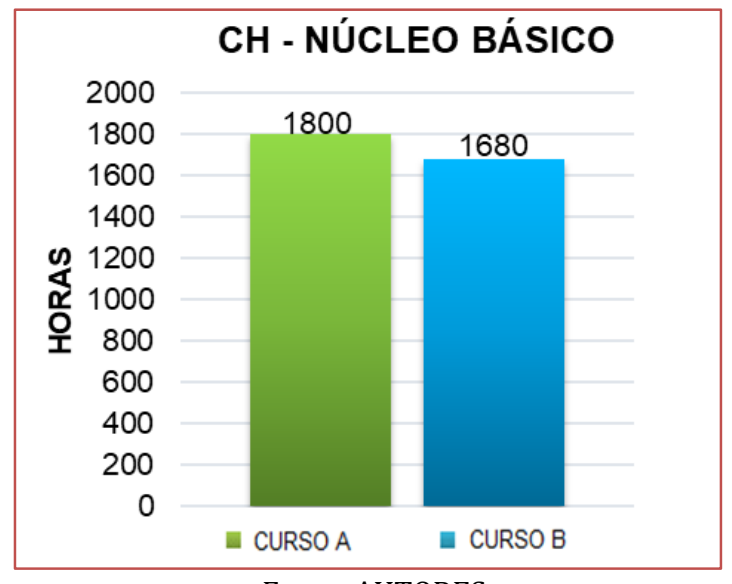

Fonte: AUTORES

Em relação à $\mathrm{CH}$ das atividades práticas, o gráfico 5 apresenta que o CURSO A oferta cerca de $45 \%$ mais $\mathrm{CH}$ do que o CURSO B.

Gráfico 5 - Comparativo de $\mathrm{CH}$ - Práticas

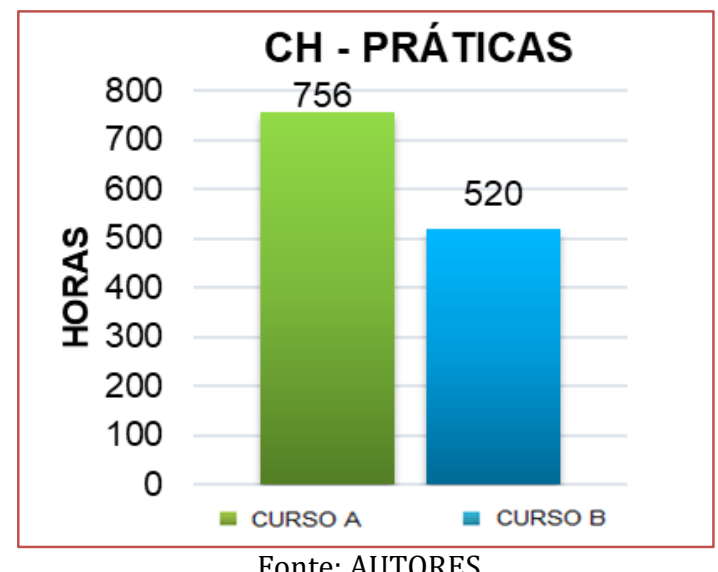

O gráfico 6 resume os resultados encontrados para as cargas horárias concentradas para grupos de disciplinas específicas, nesse caso, estruturas, instalações prediais, técnicas construtivas e geotecnia.

Gráfico 6 - Comparativo de CH - Grupos de Disciplinas Específicas

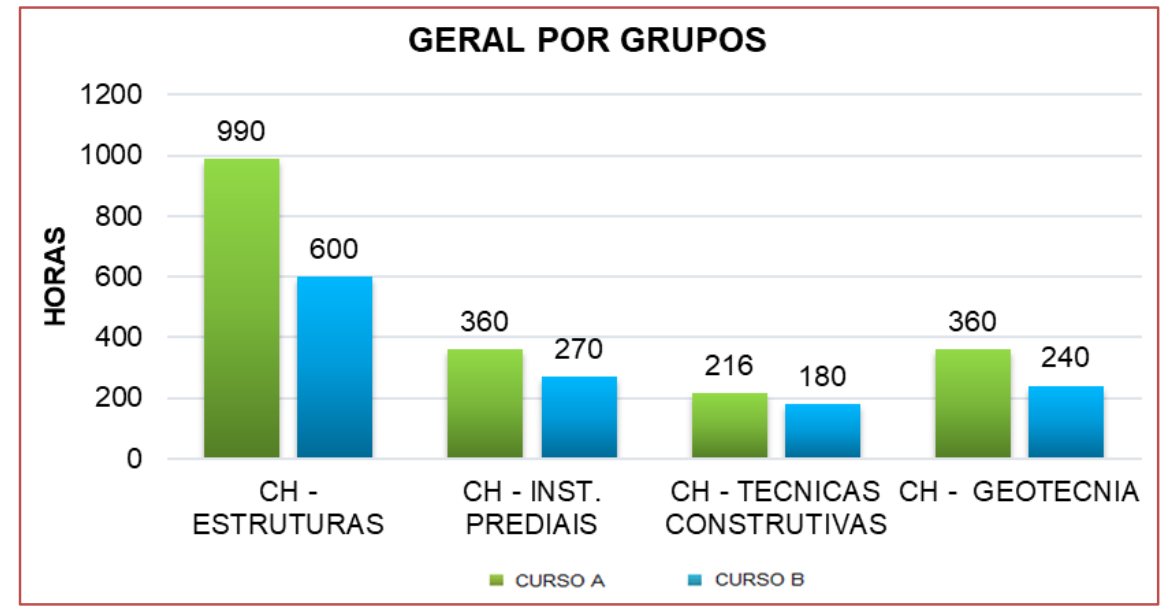

Fonte: AUTORES 
Observando os resultados d gráfico 6, fica evidente que há uma discrepância significativa entre as cargas horárias da maioria dos grupos estudados. Em dados percentuais, o CURSO A apresentou para o grupo de disciplinas de estruturas uma carga horária $65,00 \%$ maior que a do CURSO B, para o grupo de instalações prediais, foi 33,33\% maior, para os grupos de técnicas construtivas e geotecnia, os aumentos percentuais de carga horária foram $20,00 \%$ e $50,00 \%$, respectivamente.

Um fato interessante para essa análise é que apesar de carga horária total do CURSO A ser 10,05\% maior que o CURSO B, encontram-se grupos de disciplinas que mostram um aumento de até $65,00 \%$ da carga horária de um curso para outro.

Como não existe um mínimo estimado para cada grupo e a legislação vigente dá autonomia as instituições de ensino para montarem sua própria carga horária, desde que suficiente para atender as habilidades e competências esperadas para o profissional de engenharia civil. Não há como estabelecer um critério para uma avaliação mais precisa, no entanto, essas diferenças podem revelar que ou um curso está com excesso de horas para determinada área, ou o outro apresenta uma carga horária bem reduzida.

Vale ressaltar que o intuito da pesquisa é levantamento de dados para uma comparação de carga horária entre os dois cursos estudados, mostrando as principais diferenças, para que se tenha dimensão de como esses fatores podem afetar na formação profissional. Vários outros critérios devem ser levados em consideração, uma vez que além da instituição e do curso, o estudante é peça fundamental no processo de ensino-aprendizagem e no seu desenvolvimento profissional.

De fato, é importante relatar que o espaço amostral utilizado na pesquisa, se comparado com a população dos cursos de engenharia civil do Brasil, não apresenta dados que possam ser considerados representativos, uma vez que trata apenas de dois cursos. No entanto, a pesquisa é extremamente válida para revelar a discrepância que pode ser encontrada na oferta de dois cursos de engenharia civil cujas instituições se encontram em uma mesma região territorial e formarão profissionais para atender ao mesmo universo de demanda.

\section{CONSIDERAÇõES FINAIS}

O estudo realizado para elaboração desse artigo apresentou conceitos relevantes acerca da educação em engenharia civil e de sua matriz curricular. Além disso, foi realizada uma análise comparativa entre as cargas horárias dos cursos de engenharia civil do CURSO A e da CURSO B, que revelou aspectos importantes para o fortalecimento das discussões sobre a formação do profissional de engenharia civil.

A análise comparativa entre as cargas horárias dos componentes curriculares revelou que o curso de engenharia civil do CURSO A tem uma carga horária total 10,05\% maior que o curso da CURSO B.

Esses números ficam ainda mais significativos quando analisamos os grupos específicos de disciplinas, como por exemplo, a carga horária para disciplinas práticas, nas quais o CURSO A apresenta um percentual de $45,00 \%$ a mais que no CURSO B. As cargas horárias de disciplinas optativas do CURSO B tem apenas $30 \%$ de $\mathrm{CH}$ em relação ao CURSO A.

No quesito disciplinas da área de estrutura, o CURSO A também apresentou um aumento significativo de horas em relação ao CURSO B, cerca de 65,00\% de CH. As disciplinas de Instalações Prediais, Técnicas Construtivas, e Geologia apresentaram diferença de CH do CURSO A superior ao CURSO B de 33\%, 20\% e $50 \%$.

Por fim, o artigo exerce um papel fundamental para a produção de conhecimento acerca da educação em engenharia civil, uma vez que fortalece as discussões sobre as matrizes curriculares, bem como a formação profissional. Destacando que apesar da análise ser de apenas dois cursos, os mesmos estão em cidades que distam cerca de apenas $40 \mathrm{~km}$ e atendem uma demanda de cerca de 50 municípios do interior de Alagoas.

\section{REFERÊNCIAS}

[1] ASSOCIAÇÃO BRASILEIRA DE EDUCAÇÃO EM ENGENHARIA - ABENGE.

[2] Relatório encaminhado após a reunião da comissão CES/CNE, MEI/CNI e ABENGE.

[3] ABENGE, 2018. Disponível em: <http://www.abenge.org.br/file/MinutaParecerDCNs_07032018.pdf>. Acesso em: 13 fev. 2019. 
[4] ASSOCIAÇÃO BRASILEIRA DE EDUCAÇÃO EM ENGENHARIA - ABENGE. Parecer CNE/CES №: 1/2019. ABENGE, 2019. Disponível em: <http://www.abenge.org.br/file/DCNs\%20Engenharias2019_aprovadas\%20pelo\%20 CNE.pdf>. Acesso em: 13 fev. 2019.

[5] CASALE, A. Aprendizagem baseada em problemas: desenvolvimento de competências para o ensino em engenharia. 173 f. Tese (Doutorado). Escola de Engenharia de São Carlos, Universidade de São Paulo, São Carlos, 2013.

[6] CONSELHO NACIONAL DE EDUCAÇÃO - CÂMARA DE EDUCAÇÃO SUPERIOR CNE/CES. Resolução no 11, de 11 de mar. 2002. Institui Diretrizes Curriculares Nacionais do Curso de Graduação em Engenharia. 2002.

[7] INSTITUTO NACIONAL DE ESTUDOS E PESQUISAS EDUCACIONAIS ANÍSIO TEIXEIRA. Sinopse Estatística da Educação Superior 2017. Inep: Brasília, 2018. Disponível em: <http://inep.gov.br/sinopses-estatisticas-da-educacaosuperior>. Acesso em: 13 fev. 2019.

[8] SOUZA, A. P. A. et al. A valorização das competências na formação e na atuação de engenheiros: a visão de estudantes de uma instituição pública. Revista de Ensino de Engenharia, v. 34, n. 2, p. 19-30, 2015.

[9] VILELA, André L. da M., VILELA, Gilvânia L.da S., LIMA, Emerson de O. Ensino a distância para cursos presenciais de engenharia: o caso da escola politécnica de Pernambuco: Revista de Ensino de Engenharia, v. 35, n. 1, p. 45-56, 2016. 


\title{
Capítulo 10
}

A aquisição de competências humanas sob a percepção dos alunos de um curso superior semipresencial de logística - Um estudo de caso

\author{
Alessandra de Paula \\ Elton Ivan Schneider \\ Luciano Furtado Corrêa Francisco \\ Roberto Candido Pansonato \\ Robson Seleme \\ Rosinda Angela da Silva
}

Resumo: 0 crescimento de oferta de cursos de graduação na modalidade semipresencial (ensino híbrido) vem atender uma parcela significativa de pessoas que desejam cursar uma faculdade e não podem frequentar diariamente as salas de aulas. As instituições do ensino superior (ies), atentas à dimensão desse mercado, a partir da aprovação da portaria $\mathrm{n}^{0}$ 1.428/18 do ministério da educação (mec), a qual dispõe sobre a oferta de disciplinas na modalidade a distância em cursos de graduação presencial, tem criado diversas opções aos estudantes para cursarem uma graduação em um modelo onde parte da construção do conhecimento é realizada a distância e parte é presencial. Dessa forma, esse modelo atende bem as prerrogativas dos jovens que necessitam entrar no mercado de trabalho. A partir desse viés, este artigo tem com proposta analisar se os estudantes que optaram pelo ensino híbrido consideram que tem adquirido e desenvolvido competências humanas por meio desse modelo. Para isso, foi realizada uma pesquisa de percepção com uma turma de tecnólogos em logística, os quais se encontram duas vezes por semana para ampliar os conhecimentos. Os resultados evidenciaram como os estudantes percebem a aquisição de competências humanas por meio das atividades práticas realizadas nos encontro semipresenciais.

Palavras-chave: Educação a distância. Logística. Modelo semi presencial. Competências humanas. 


\section{INTRODUÇÃO}

O ensino semipresencial - também chamado de ensino híbrido - em cursos de graduação, no Brasil, foi impulsionado com a publicação da Portaria no 21 2.253/2001, posteriormente atualizada pelas portarias no 4.059/04, no 1.134/2016 e mais recentemente pela MEC Portaria no 1.428/18. De acordo com essas diretrizes, os cursos de graduação de nível superior no Brasil podem oferecer até $40 \%$ (quarenta por cento) da carga horária total da grade por meio da modalidade à distância (desde que cumpram também outros requisitos). Dessa forma, cursos de graduação regularmente autorizados, que sejam ofertados na modalidade presencial, e uma vez cumpridos outros dispositivos legais, podem implementar parte de sua execução a distância e parte de forma presencial. Esta modalidade de ensino combina a educação à distância com o ensino tradicional em sala de aula. Ainda que o ensino híbrido seja tão recente quando a modalidade $100 \%$ à distância - conhecida simplesmente como EAD - nos cursos superiores brasileiros, essa modalidade vem crescendo muito nos últimos anos. Segundo dados da Associação Brasileira de Ensino (Abed), para cada curso 100\% a distância criado nos anos de 2016 e 2017, foram inaugurados quatro cursos semipresenciais no mesmo período. Outros dados reforçam esse crescimento. Conforme exposto no $10^{\circ}$ Censo EAD.BR (2017) - relatório periódico com dados sobre o ensino à distância no Brasil, patrocinado pela Associação Brasileira de Educação a Distância (ABED) -, um estudo apresentado pela Consultoria Educa Insights no XI Congresso Brasileiro da Educação Superior Particular apresentou uma projeção de crescimento de alunos no ensino superior brasileiro nas modalidades presencial, EAD e semipresencial. 0 destaque do estudo fica por conta da projeção de crescimento de matrículas no ensino semipresencial, conforme é possível constatar na figura 1:

Gráfico 1 - Cursos presenciais, totalmente a distância e híbridos (semipresenciais): projeção para o total de matrículas em IES particulares

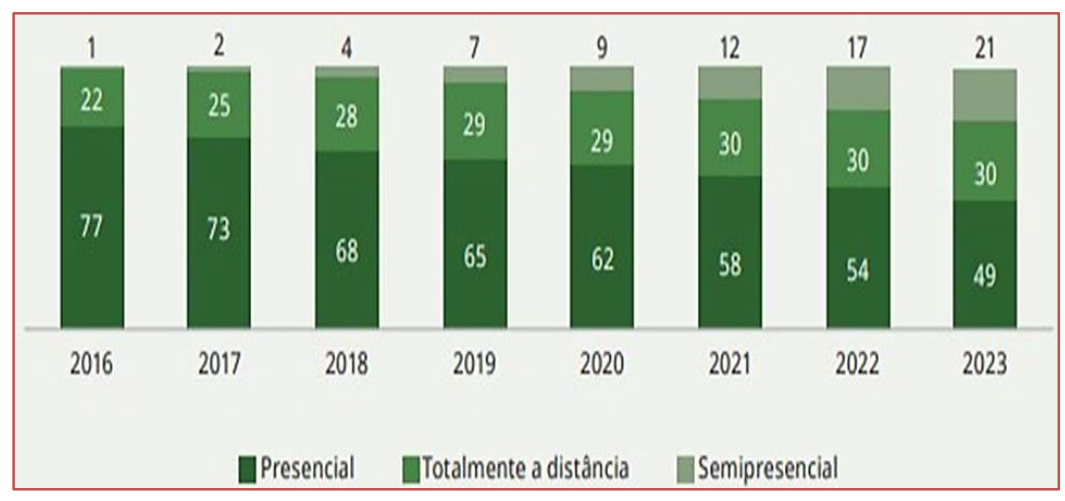

Censo EAD.BR: relatório analítico da aprendizagem a distância no Brasil 2017 [livro eletrônico]/[organização] ABED - Associação Brasileira de Educação a Distância. Curitiba: InterSaberes, 2018.

Partindo dessas informações, tem-se verificado no Brasil que as instituições de ensino superior têm empreendido esforços contínuos em desenvolver novas maneiras de ensinar e conceber o aprendizado, fazendo uso de variadas metodologias de ensino e com forte utilização de tecnologias digitais. Assim, desde a publicação da Portaria 1.428/2018, que aumentou a percentagem da parcialidade à distância, aumentou a quantidade de cursos superiores que unem a EAD com o ensino presencial. 0 EaD procura constantemente se atualizar em suas metodologias, uma vez que fatores como espaço, tempo e outros estão naturalmente arraigados na mente humana quando pensa em processos de ensino-aprendizagem. Logo, a estruturação de ensino EaD não deve se pautar exclusivamente nos recursos tecnológicos, mas primordialmente sobre os anseios dos alunos, fato corroborado por Alava (citado por Goncalves e Arruda, 2005, p. 186), o qual menciona que as metodologias EaD devem se apoiar "na construção de um modelo global dos processos de ensino, integrando essas tecnologias no centro da dinâmica de ação". Christensen et al. (2009) dizem que a inovação nos processos de ensino-aprendizagem é vital para que o aluno se interesse pelo objeto do estudo, relacionando esse objeto com sua realidade e necessidades, integrado ao seu tempo, tornando o aluno capaz de participar do mundo do trabalho. Igualmente, uma parte dos jovens brasileiros precisa ingressar no mundo do trabalho ao terminarem a educação básica. Assim se verifica uma alteração no cotidiano dessas pessoas, um fator dificultador para realizar um curso superior. Razões como deslocamentos, distância das IES do trabalho ou da residência e despesas, elementos inerentes de 
um curso superior presencial, fazem por desestimular, nesse contingente, a matrícula em uma faculdade. Logo, as modalidades à distância se tornam alternativa viável, contanto que o aluno se conscientize da necessidade de disciplina para realizar um curso à distância. Essa disciplina, contudo, não é algo de internalização imediata por muitos desses alunos. Não porque não tenham disciplina ou a releguem, mas porque a mudança significativa dos paradigmas de ensino presencial - ao qual ele sempre esteve habituado na educação básica - faz com que sintam uma alteração drástica no processo, dificultando sua adaptação em curto e médio prazo, fazendo com que uma parte desses alunos desista de cursar uma faculdade à distância. É nesse contexto que a modalidade semipresencial surge como uma alternativa a estudantes que desejam ter as facilidades e recursos proporcionados pelo EaD, contudo desejam ter um contato presencial com professores e colegas, obtendo as características mais desejáveis dessas duas abordagens.

\subsection{ENSINO-APRENDIZAGEM EM MODALIDADES À DISTÂNCIA}

As profundas transformações políticas, econômicas e sociais verificadas nas últimas décadas atingiram também os processos educacionais. Nota-se que os modelos tradicionais de ensino-aprendizagem não têm tido mais o êxito esperado para abranger as necessidades dos discentes, num mundo cada vez mais complexo, interconectado e global. O conhecimento se disseminou com as tecnologias da informação e hoje não é mais "propriedade" de um indivíduo, que o adquire e o transmite, num ciclo retroalimentado. Tal pensamento é confirmado por Strieder (2002, p.11), que diz que "o mundo vive em constante e cada vez mais rápido processo de mudanças. 0 cenário humano e econômico requer formas educacionais mais flexíveis para também formas de trabalho e carreiras flexíveis". 0 autor preconiza que as alterações referentes à produção, disseminação e absorção do conhecimento se dão numa velocidade sem precedentes e, nesse contexto, a educação deve proporcionar às pessoas uma forma de lidar racionalmente com a imensa quantidade de informações disponíveis. Devido a isso, as metodologias de ensino presencial, à distância e semipresencial apresentam significativas diferenças em suas abordagens de ensino-aprendizagem. No ensino clássico presencial, o professor é o detentor do conhecimento e o repassa aos alunos na forma de aulas expositivas, aplicação de atividades práticas e, ao final, por meio de avaliações individuais ou em grupo, ele, o professor, aufere a absorção do conhecimento transmitido ao aluno. Nas modalidades EaD, o cenário é praticamente oposto, ou seja, a figura do professor inexiste em sua concepção tradicional. 0 aluno tem uma série de materiais que têm o conteúdo a ser estudado, em variados formatos: textos, livro, vídeos, áudios, entre outros - normalmente em meio digital, acessado via internet, sendo o responsável por estudar tais conteúdos nos momentos e nos locais em que entender mais adequados propiciando, assim, flexibilidade e liberdade de ação. A concepção se inverte: é o estudante que deve buscar conteúdos de ampliação da aprendizagem, pois não há a figura do professor que repassará conteúdo em dia, hora e local previamente combinados. Ao refletir sobre o cenário apresentado, percebe-se que não existe uma forma única de aprender, logo, também não existe uma única forma de ensinar. Os aspectos colaborativos, próprios do sistema à distância e também do ensino semipresencial, aliados aos recursos tecnológicos, proporcionam diversos momentos de aprendizagem e permuta de conhecimentos que vão muito além das paredes de uma sala de aula. 0 fato de também aprender com o grupo de colegas torna o aprendizado ainda mais significativo, pois o grupo tem um objetivo comum, conforme se demonstra na Figura 1.

Figura 1 - Atividades e Recursos Pedagógicos em EAD

\begin{tabular}{|c|c|c|c|c|c|c|}
\hline \multirow[b]{2}{*}{ Atividades e Recursos Pedagógicos } & \multicolumn{6}{|c|}{ Etapas do Processo de Aprendizagem } \\
\hline & $\begin{array}{l}\text { Lembrar / } \\
\text { Memorizar }\end{array}$ & $\begin{array}{l}\text { Compreender } \\
\text { / Entender }\end{array}$ & $\begin{array}{l}\text { Analisar / } \\
\text { Identificar }\end{array}$ & $\begin{array}{l}\text { Aplicar I } \\
\text { Resolver }\end{array}$ & $\begin{array}{l}\text { Sintetizar / } \\
\text { Concluir }\end{array}$ & $\begin{array}{l}\text { Avaliar / } \\
\text { Decidir }\end{array}$ \\
\hline 1 Livro Didático (impresso ou digital) & 4 & 4 & 4 & 4 & 5 & 3 \\
\hline 2 Video Aulas & 2 & 4 & 4 & 3 & 5 & 5 \\
\hline 3 Rota de Aprendizagem & 6 & 7 & 6 & 3 & 4 & 4 \\
\hline 4 Fóruns & 7 & 7 & 6 & 6 & 3 & 4 \\
\hline 5 Aulas Interativas & 7 & 7 & 7 & 7 & 7 & 7 \\
\hline 6 Atividade Prática Presencial - APP & 7 & 7 & 6 & 4 & 2 & 5 \\
\hline \begin{tabular}{l|l}
7 & Trabalho disciplinar Aplicado - TDA \\
\end{tabular} & 6 & 6 & 5 & 5 & 3 & 6 \\
\hline 8 Atividade Pedagógica Online - APOL & 4 & 4 & 4 & 3 & 4 & 4 \\
\hline 9 Avaliação Objetiva - AO & 4 & 3 & 3 & 2 & 4 & 4 \\
\hline 10 Avaliação Discursiva - AD & 4 & 2 & 3 & 2 & 4 & 4 \\
\hline 11 Oficinas & 4 & 2 & 3 & 2 & 4 & 4 \\
\hline
\end{tabular}

Fonte: Os autores 
Em questão de modelos de ensino-aprendizagem, o ensino semipresencial se dá com a presença do aluno, duas vezes por semana, no Polo de Apoio Presencial (PAP) onde ele está matriculado. 0 objetivo desses encontros não é o de repassar conhecimentos em aulas expositivas e com assuntos ainda desconhecidos pelo aluno, mas a execução de atividades práticas diversas, com uso de metodologias ativas, no intuito de impulsionar a aprendizagem. É a aplicação da sala de aula invertida, metodologia na qual o estudante tem contato com o conteúdo antes do encontro presencial, por meio dos recursos à distância - em geral pelo Ambiente Virtual de Aprendizagem (AVA) - e posteriormente realiza atividades práticas para assimilação desse conteúdo. Nesse sentido, o professor é um mediador do processo, um facilitador para o aluno na busca pela aprendizagem e não um mero replicador de conteúdo. Esse cenário busca dar atrativos ao aluno por meio da interação com colegas e professor, na troca de experiências e construção do saber integrado e colaborativo. $O$ aluno é um agente ativo no processo de ensino nas modalidades EaD, também no modelo semipresencial. Essa visão vantajosa do modelo semipresencial é corroborada por Christensen et al. (2013), quando dizem que "em muitas escolas, o ensino híbrido está emergindo como uma inovação sustentada em relação à sala de aula tradicional". Para os autores, o ensino semipresencial é a concretização da obtenção pelo aluno do melhor de dois mundos, a agilidade e facilidade da EaD e as vantagens existentes em uma sala de aula tradicional. Os autores completam, mencionando que o ensino semipresencial "seja reconhecido como uma forma diferente de possibilitar aos discentes um conhecimento diferente da forma tradicional, ainda tão difundida e enraizada nas Escolas" (CHRISTENSEN et al, 2013, p.3).

\section{AQUISIÇÃO DE COMPETÊNCIAS NA FORMAÇÃO DO ALUNO DO SEMIPRESENCIAL}

Vislumbrando os cenários de ensino-aprendizagem da educação à distância e mesmo a sua modalidade semipresencial, acentua-se ainda mais a aquisição de competências técnicas e cognitivas. Isto é expresso pela existência de menor carga horária de interação presencial entre professor-aluno e aluno-aluno. É imprescindível entender, no entanto, que a aquisição de competências humanas é um dos objetivos do processo de ensino, contribuindo para sua evolução moral. 0 ser humano é de natureza complexa, na qual os vários aspectos funcionam como um sistema de inter-relações, e não por meio de compartimentos separados e incomunicáveis. Portanto, a transmissão de valores e competências humanas deve ser embutida no sistema de ensino, seja qual for a modalidade. A formação integral do discente deve ser valorizada, tanto quanto sua formação técnica-cognitiva. As formas de aprender e ensinar das modalidades à distância e semipresencial também devem proporcionar os saberes que levem o aluno a desenvolver espírito crítico, cooperação, liberdade, autonomia, reflexão, pensamento inovador, flexibilidade, resiliência e comprometimento com seu autodesenvolvimento e sua formação continuada. Segundo Gondim et. al. (2014, p. 395), existem dois grupos de competências profissionais: as profissionais, que são exigidas em qualquer atividade e que podem ser exercidas em diversos contextos; e as "competências socioemocionais, que se situam no domínio de processos afetivo emocionais, pessoais e interpessoais". As competências profissionais mobilizam os recursos do indivíduo no âmbito do conhecimento e suas aplicações técnicas, atitudes e valores, as competências socioemocionais são as que possibilitam o desenvolvimento e a expressão das anteriores. Ainda conforme as autoras "o domínio de aspectos motivacionais e afetivos, em si e nos outros, assegura a aprendizagem, o desenvolvimento e a transferência dessas capacidades para outros contextos laborais" (GONDIM, MORAES e BRANTES, 2014, p. 395). Tal posicionamento é corroborado por Abed (2014), quando menciona que o desenvolvimento de habilidades específicas, em relação à seleção e processamento de informações, tomada de decisões, trabalho em equipe, administração das emoções, é chave para um bom desempenho acadêmico e para o sucesso do aluno em sua vida profissional, pessoal e social. Outro aspecto importante nesse cenário é que o corpo discente de cursos EaD e semipresenciais é, em sua maioria, formado por pessoas acima de faixa etária convencional para o âmbito universitário - pessoas entre 18 e 24 anos de idade, em média. São indivíduos um pouco mais velhos do que isso, que já estão no mercado de trabalho, ao contrário dos cursos de modalidade presencial. Assim, esse público já possui aquisições de conhecimento empírico de formação humana, aqueles elencados anteriormente. A experiência maior de vida pessoal e também no campo profissional destes alunos torna a tarefa de transmissão de competências humanas ainda mais complexo, dado que o aluno já tem um cabedal de conhecimentos tácitos nesse sentido e, naturalmente, irá compará-los com as competências humanas que o curso à distância pretende lhe transmitir. Se por um lado esses conhecimentos tácitos podem facilitar o trajeto do aluno à aquisição das competências humanas elencadas pelo curso superior podem, em certos casos, dificultar essa assimilação, justamente pelo fato do confronto entre aquilo que ele já vivenciou contra o que é procurado lhe ensinar por meio da educação 
formal. Dessa forma, este estudo tem o objetivo de identificar a percepção de alunos do curso de Tecnólogo em Logística - modalidade semipresencial, de uma IES de Curitiba, a respeito da eficácia de aquisição das competências humanas necessárias às demandas do mercado e da sociedade.

\section{PROCEDIMENTO METODOLÓGICO}

Esse artigo foi realizado a partir de pesquisa de abordagem qualitativa, descritiva quanto a sua finalidade e bibliográfica quanto ao procedimento adotado. Em relação à pesquisa qualitativa, foi utilizada porque "não se preocupa com representatividade numérica, mas, sim, com o aprofundamento da compreensão de um grupo social, de uma organização, etc". (GERHARDT, SILVEIRA, 2009, p.31). Foi realizada também uma pesquisa de percepção com os 21 estudantes da turma de Tecnólogo em Logística no primeiro quadrimestre de 2019 e, como instrumento de coleta de dados, foi utilizado um questionário estruturado onde o estudante utilizou uma escala de 1 a 7 (1 para pouco e 7 para muito) com o intuito de demonstrar se as atividades realizadas nos encontros presenciais contribuíram significativamente para a formação do perfil profissional e aquisição de competências humanas, previstos pelas disciplinas.

\section{RESULTADOS E DISCUSSÃO}

0 questionário entregue aos estudantes participantes da pesquisa apresentava quatro competências humanas que fazem parte do perfil do egresso do curso Tecnólogo em Logística:

- Humanista, ético, reflexivo, crítico e responsável no desenvolvimento das dimensões econômica, social, ambiental e institucional.

- Inovador, criativo e flexível na execução de suas atividades, com resiliência, visão sistêmica e estratégica;

- Colaborativo e propositivo no trabalho em equipes e no atendimento às expectativas das partes interessadas;

- Comprometido com o seu autodesenvolvimento e formação continuada.

Os alunos foram previamente informados sobre as particularidades da pesquisa no que diz respeito à taxonomia de Bloom, bem como o perfil profissional do egresso conforme diretrizes do ensino superior para cursos de tecnologia. De acordo com a percepção do aluno, ele utilizava uma escala para identificar se as atividades propostas na Unidade temática de aprendizagem contribuíram para o seu desenvolvimento das características necessárias para construção do perfil profissional do gestor de logística. A atividade do aluno se resumia a relacionar com nota de 1 a 7: os perfis humanista, inovador, colaborativo e comprometido, sendo 1 para pouco contribuiu para o processo e 7 para uma contribuição significativa para sua formação dentro do perfil profissional previsto. Os dados foram coletados, estratificados e inseridos em um gráfico, conforme gráfico 2, que resume o perfil profissional dos alunos, segundo a formação por competências humanas.

Gráfico 2

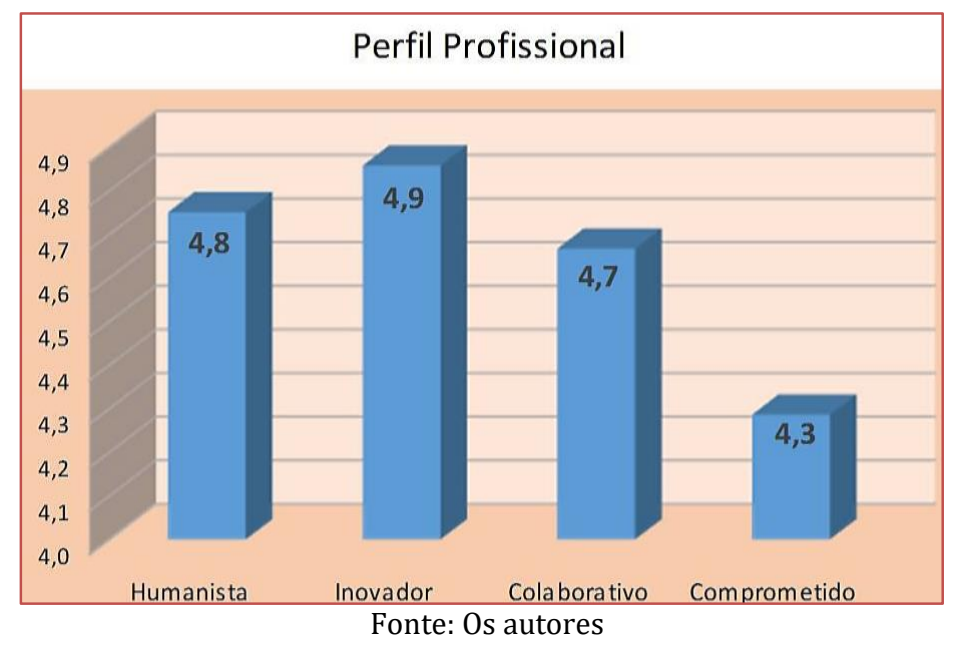


O gráfico, resumidamente, apresenta que, na percepção do aluno, existem possibilidades de melhoria, por meio das atividades práticas do ensino semipresencial e que estas colaboram para a aquisição das competências humanas propostas pelo curso. Por exemplo, na percepção do aluno, unidade temática de aprendizagem não estaria atendendo plenamente a competência "comprometido com o seu autodesenvolvimento e formação continuada", o que direciona os professores e coordenadores de curso no sentido de criar mecanismos para atender essa lacuna. Em relação aos materiais e atividades disponibilizados no curso, os alunos apontaram que, por exemplo, as atividades práticas $(6,0)$ e o trabalho disciplinar $(5,9)$ são bastante significativos, oferecendo-lhes conhecimentos aplicáveis, que contribuirão para solucionar problemas profissionais futuros. As atividades pedagógicas $(5,7)$ também foram apontadas como significativas, seguidas das aulas interativas e rotas de aprendizagem $(5,4$, ambas). A avaliação discursiva vem na sequência $(5,1)$ ao lado da avaliação objetiva, com o mesmo percentual. Por último, os alunos apontam as videoaulas $(5,0)$ e o livro didático $(5,0)$ como sendo os materiais que menos contribuem para sua formação profissional, considerando-se as competências humanas a serem desenvolvidas.

Gráfico 3 - Aplicabilidade e soluções

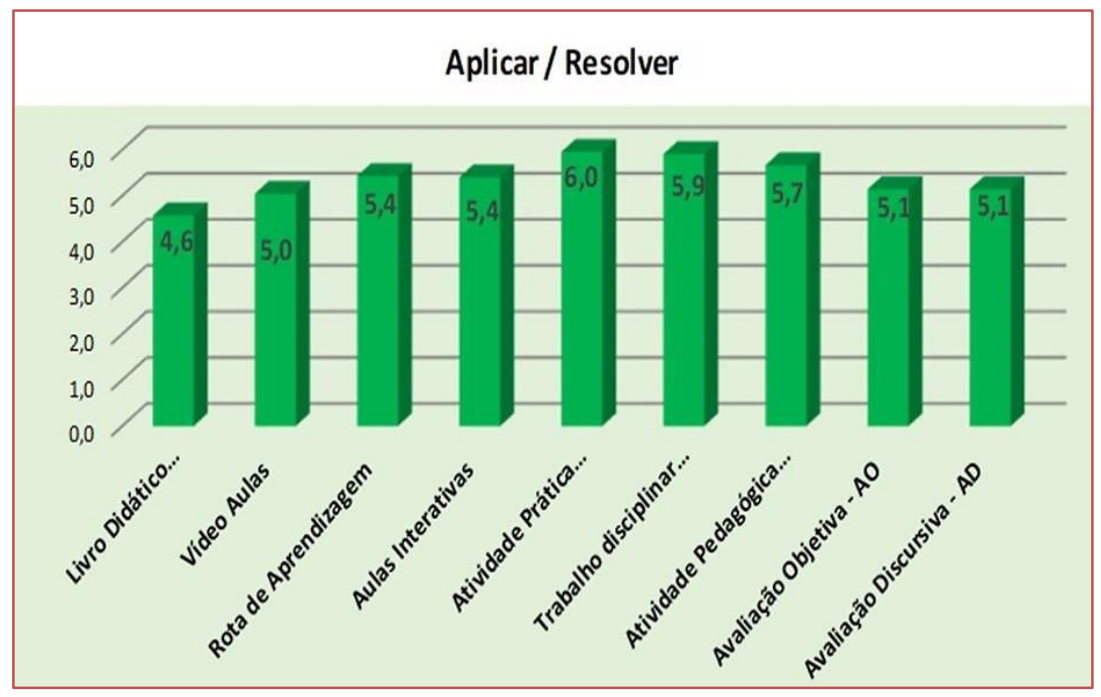

Fonte: Os autores.

\section{CONSIDERAÇÕES FINAIS}

O ensino a distância no Brasil tem se apresentado como uma opção viável para muitas pessoas que precisam conciliar trabalho e estudo e que não conseguem frequentar aulas presenciais diariamente. Como no Brasil espera-se que o jovem que conclua o ensino médio entre imediatamente no mercado de trabalho, as modalidades à distância ou semipresencial tem sido a opção de muitos, os quais buscam cursos que possam qualificá-los de forma que aumentem as chances de inserção no mercado. As IES cientes dessas demandas e beneficiadas pela Portaria do MEC nํㅜ 1.428/18, ampliaram as ofertas desses cursos e se prepararam para receber mais estudantes nessas modalidades. Junto a isso, aumentou a preocupação em identificar se o estudante que opta por cursos EAD ou semipresenciais consegue desenvolver as competências humanas requeridas pela profissão almejada por meio dos estudos dos conteúdos apresentados nos materiais virtuais e nas oficinas realizadas em sala de aula, no caso do modelo semipresencial. Uma preocupação da Uninter com relação ao sistema presencial é a de que o aluno adquira tanto as competências técnicas quanto às competências humanas previstas em seus PPCs. Uma vez que na modalidade semipresencial, o intuito dos encontros presenciais é o de realizar atividades práticas que fortaleçam os conceitos técnicos das disciplinas, o estudo teve o objetivo de auferir se as competências humanas também estavam sendo transmitidas e adquiridas de forma efetiva. 0 estudo aqui apresentado considerou as respostas dos 21 estudantes do curso Tecnólogo em Logística que participaram da pesquisa de percepção sobre os elementos que auxiliam maior ou menor grau no desenvolvimento das competências humanas. Os resultados demonstraram que as notas atribuídas pelos estudantes mantiveram a média entre 4 e 5 pontos, o que significa que eles consideram que os diferentes recursos utilizados pela IES corroboram as competências humanas de forma equilibrada. Já a IES pode avaliar quais elementos precisam ser intensificados e quais precisam ser substituídos para que o 
estudante tenha uma percepção mais acurada daqueles que contribuem mais significativamente para sua formação profissional e também para a aquisição de competências humanas.

\section{REFERÊNCIAS}

[1] ABED, Anita Lilian Zuppo. O desenvolvimento das habilidades socioemocionais como caminho para a aprendizagem e o sucesso escolar de alunos dabásica. São Paulo, 2014.

[2] CHRISTENSEN, C.M; HORN, M. B.; STAKER, H. Híbrido: uma Inovação Disruptiva? Uma introdução à teoria dos híbridos. Clayton Christensen Institute for Disruptive Innovation. Tradução da Fundação Lemann e Instituto Península. MAIO 2013.

[3] GERHARDT, Tatiana Engel. SILVEIRA, Denise Tolfo. (Organizadoras). Métodos de pesquisa. Porto Alegre: Editora UFRGS, 2009.

[4] GONÇALVES, Irlen Antonio e ARRUDA, Eucídio. Educação a Distância: uma inovação do fazer pedagógico? Revista Paideia. Revista do Curso de Pedagogia da Universidade FUMEC. Ano IV, no 03, 2005. Disponível em < http://www.fumec.br/revist as/paideia/article/view/915/691 > . Acesso em 08 mai 2019.

[5] GONDIM, Sônia Maria Guedes; MORAIS, Franciane Andrade de; BRANTES, Carolina dos Anjos Almeida. Competências socioemocionais: fator-chave no desenvolvimento de competências para o trabalho. Rev. Psicol., Organ. Trab., Florianópolis, v. 14, n. 4, p. 394-406, dez. 2014. Disponível em < http://pepsic.bvsalud.org/scielo php?script=sci_arttext\&pid=S1984-66572014000400006\&lng=pt\&nrm=iso >. Acesso em 08 maio 2019.

[6] STRIEDER, Roque. Educação e humanização: por uma vivência criativa. Florianopolis, SC.: Habitus, 2002. 


\section{Capítulo 11}

Nova forma de aprender dermatologia: Oportunidade de inovação a partir da reforma curricular na graduação de Medicina

Ana Maria Rodrigues dos Santos

José Ricardo Costa Basilio

Attilio Valentini

Fatima Maria Alves Minuzzo

Luciana Teixeira Velloso

Aline Albino Quintanilha Faver

Resumo: Em uma reforma curricular, de um curso de graduação em Medicina, surgiu a oportunidade de utilização de tecnologia educacional, a partir de solução educacional planejada e implementada pelos professores de Dermatologia. Essa experiência é apresentada neste artigo, apontando as metodologias / estratégias utilizadas, bem como as ferramentas digitais e os resultados alcançados.

Palavras-chave: Tecnologia educacional; sala de aula invertida; videoaulas; graduação em medicina, educação a distância 


\section{INTRODUÇÃO}

Com o intuito de atender as demandas atuais referentes à formação profissional e à formação cidadã para o mundo do trabalho e para a vida, sempre considerando as Diretrizes Curriculares Nacionais (2014) e Internacionais - Tomorrow's Doctors (2009) e CanMEDS (2005) -, foram definidas novas orientações pedagógicas do processo de aprendizagem no curso de Medicina, que estão registradas no Projeto Pedagógico do Curso (2017), produto de estudo e debate da comunidade acadêmica, que culminou em uma reforma curricular. Como fruto dessa reforma, foi delineado um novo desenho educacional que afetou unidades curriculares, tanto no que diz respeito ao conteúdo programático quanto à carga horária e que, consequentemente, impulsionou mudanças metodológicas.

Uma dessas mudanças é apresentada neste relato: como a equipe de professores da unidade curricular Dermatologia se organizou para que o processo de aprendizagem se mantivesse de qualidade, atendendo ao novo modelo educacional, organizado pela reforma curricular.

\section{OBJETIVO}

Este relato tem como objetivo apresentar a solução educacional planejada e implementada para a unidade curricular Dermatologia, da graduação de Medicina, que surgiu como uma oportunidade de uso da tecnologia e de inovação para o processo de aprendizagem, através da parceria entre professores da Graduação, com especialistas em educação a distância da Coordenação de EAD, em uma instituição de ensino superior.

\section{REFERENCIAL TEÓRICO}

\subsection{TECNOLOGIAS E EDUCAÇÃO NO SÉCULO XXI}

A sociedade é desafiada, constantemente, a gerir as mudanças ocorridas no século XXI e a educação não pode ficar alheia a isso. São necessárias novas formas de pensar a educação, em que gestores, professores e alunos atuem como agentes de transformação, favorecendo a integração de processos inovadores e o uso de recursos tecnológicos, com foco na qualidade educacional, a fim de desenvolver competências requeridas ao cidadão do século XXI, que deve ser, de acordo com a International Society for Technology in Education (ISTE, 2016):

- Aprendiz "empoderado" (Empowered learner), que utiliza a tecnologia para definir metas pessoais, desenvolver estratégias individuais e de trabalho cooperativo, bem como para melhorar os resultados de sua aprendizagem;

- Cidadão digital, que reconhece seus direitos, responsabilidades e oportunidades de viver, aprender e trabalhar em uma rede digital interconectada com o mundo, agindo de forma segura, legal e ética;

- Construtor de conhecimento, que utiliza ferramentas digitais para construir conhecimento e participar de experiências de aprendizagem significativa para si e para os outros, explorando, ativamente, situações-problema do mundo real, desenvolvendo ideias e teorias e buscando respostas e soluções;

- Designer inovador, que faz uso da tecnologia para identificar e resolver problemas, por meio de soluções úteis e criativas;

- Pensador computacional (Computational thinker), que emprega estratégias para entender e resolver problemas, com uso de métodos tecnológicos para desenvolver e testar soluções;

- Comunicador criativo, que se comunica e se expressa clara e criativamente, usando plataformas, ferramentas, estilos, formatos e mídia digital apropriados aos seus objetivos;

- Colaborador global, que utiliza ferramentas digitais para enriquecer a sua aprendizagem, trabalhando de forma cooperativa local e globalmente.

Dessa forma, o processo de aprendizagem deve ser entendido e estimulado para que ocorra em rede, onde o foco é o sujeito que aprende, considerando-o como um indivíduo autônomo, capaz de gerir o seu aprender, tendo o professor o papel de mediador e a instituição como responsável por oferecer condições favorecedoras e motivadoras. 
Para trabalhar nas modalidades a distância ou semipresencial ou, tão somente, com seus métodos e recursos, aplicados à educação presencial e com foco na educação do século XXI, a instituição deve estar preparada para oferecer aprendizagem significativa e de qualidade, preservando todas as características de uma boa educação, capaz de possibilitar, a cada estudante, o desenvolvimento de suas capacidades cognitivas, sociais, emocionais, profissionais e éticas e para poder viver em sociedade, exercitando sua cidadania plena.

No entanto, ainda hoje, muitas instituições de ensino adotam estratégias tradicionais, com cunho, predominantemente conteudista, que as engessa nas suas práticas. Muitas instituições têm um foco apenas no desenvolvimento de competências técnicas e na transmissão de conteúdos, deixando de lado o desenvolvimento das competências comportamentais. Para atender as resoluções que impõem esta carga de conteúdos, as instituições dispõem esta carga mesmos aos alunos, de forma que estes apenas venham a focar a aprovação nas avaliações, nas provas, mas não na compreensão, aplicação e crítica dos conteúdos ali, meramente, assimilados.

Grande parte do público atual das instituições de ensino superior cresceu na revolução digital, possibilitada pelo avanço das tecnologias da informação e tiveram o computador como um elemento de consulta e interação presente. Isso se deve, principalmente, pela queda de custo dos equipamentos (celulares, laptops etc), assim como a maior facilidade para acesso à rede.

O fluxo de informações, apoiado em blogs, websites e, principalmente, em redes sociais tais como Instagram, Whatsapp, Youtube e Facebook, fazem com que tradicionais meios de comunicação se tornem ultrapassados. Netflix, Amazon Prime, Fox Play e Youtube, entre outros, permitem ao espectador escolher a hora que vai assistir ao seu programa. E mais, permite - no caso do Youtube - que o espectador também seja autor do seu próprio vídeo, que é diferença fundamental das grandes companhias de broadcast e editoras, onde a figura do diretor/editor criava uma linha comunicacional, que deveria ser consumida. Mas a instituição de ensino não está em linha com o que este público demanda. 0 aluno que, na sua escola fundamental e média, foi obrigado a responder provas, num processo de memorização de conteúdos, chega ao ensino superior com um perfil passivo e longe do necessário para ser um profissional ou um pesquisador. Para atender a este público, estratégias pedagógicas mais alinhadas às suas necessidades emergem como respostas a motivar estes alunos. A sala de aula invertida, o estudo baseado em problemas, o estudo baseado em casos são metodologias ativas que, além de incluir contextualização e exemplos práticos nos estudos, têm potencial de proporcionar, aos alunos, uma aproximação com a realidade/cotidiano de aplicação daquela área estudada.

Essas metodologias, de acordo com Bannell et. al. (2016), refletem um paradigma pedagógico, voltado para a autonomia do estudante, conforme preconizado por Paulo Freire (2016), possibilitando a interação dos estudantes e a metarreflexão de cada um sobre os objetos que constituem o foco da aprendizagem.

Especificamente, na sala de aula invertida, "o que tradicionalmente é feito em sala de aula, agora é executado em casa e o que, tradicionalmente, é feito como trabalho de casa, agora é realizado em sala de aula". (Bergmann; SAMS, 2016, p.11)

Nesse modelo,

a aula gira em torno dos alunos, não do professor. Os estudantes têm o compromisso de assistir aos vídeos e fazer perguntas adequadas. 0 professor está presente [...] para prover feedback adequado. (BERGMANN; SAMS, 2016, p.14)

\section{PROCEDIMENTOS METODOLÓGICOS: A SOLUÇÃO EDUCACIONAL PARA A UNIDADE CURRICULAR DERMATOLOGIA}

O novo Projeto Pedagógico do Curso de Medicina foi concluído em 2017 e privilegia alguns aspectos que são esperados na educação do século XXI, dos quais destacamos: 
- Expansão da oferta de atividades educacionais centradas no estudante;

- Revisão dos objetivos educacionais de cada unidade curricular para responderem as competências finais de atenção, gestão e educação em saúde;

- Aprimoramento do feedback ao estudante;

- Acompanhamento e avaliação contínua do programa;

- Implementação de novas tecnologias educacionais;

- Utilização de resolução de problemas reais da comunidade no ensino;

- Integração das unidades curriculares e apresentação em quatro eixos. (FMP, 2017, p.44-45)

Os quatro eixos citados são:

Eixo 1 - Ser humano, sua biologia e contexto socioambiental

Eixo 2 - Saúde, adoecimento e cuidado

Eixo 3 - Sistema de saúde

Eixo 4 - Profissionalismo

De acordo com o PPC do curso de Medicina (FMP, 2017, p.45),

o eixo "Saúde, adoecimento e cuidado" é composto por unidades curriculares relativas às grandes áreas, tradicionalmente reconhecidas na formação médica, além das áreas de saúde mental e urgência e emergência como proposto pelas DCN. Neste eixo as especialidades médicas, como a dermatologia, têm foco nos conhecimentos, habilidades e atitudes relativas à área de atuação do médico generalista.

A unidade curricular de Dermatologia vivenciou, em 2018, as mudanças decorrentes dessa reforma, com a adoção da semestralidade na periodicidade do curso, que era anual, com a redução da carga horária e a concomitância de turmas (período de transição do 4ํano para o $3^{\circ}$ ano - 6o período).

Anteriormente, no $4^{\mathrm{o}}$ ano, as atividades eram realizadas em quatro grupos, com cerca de 30 alunos em cada um, por períodos de 8 semanas, sendo que as atividades teóricas eram compostas de estudos dirigidos, seminários, "clube da revista" - apresentação/discussão de artigos de periódicos científicos - e aulas expositivas, além de atividades práticas realizadas no ambulatório.

Os aspectos positivos dessa metodologia eram os seguintes:

- grupos com menor número de alunos;

- possibilidade de trabalhar as competências de forma global envolvendo conhecimentos, habilidades e atitudes;

- vivências em atividades práticas.

Em 2018, com a implantação da reforma curricular, surgiu a demanda e, com ela, a oportunidade de inovar no $3^{\text {o }}$ ano, visto que foi necessária a adequação da metodologia utilizada, para atender desafios como concomitância com as atividades do $4^{\circ}$ a ano, grande número de alunos (cerca de 120) no $3^{\circ}$ ano (envolvido na transição, devido à reforma curricular) e ausência de atividades práticas, que estão previstas, com esses estudantes, no $5^{0}$ ano - Internato.

A equipe de Dermatologia, composta por quatro professores, após muita reflexão, estudo e debate, desenhou uma solução educacional, envolvendo as seguintes estratégias: sala de aula invertida, com o uso de videoaulas; TBL (Team Based Learning), adaptado às necessidades da unidade curricular e "Júri Simulado".

Com esse desenho, procurou a Coordenação de Educação a Distância da instituição, a fim de estabelecer uma parceria para produção dos vídeos e publicação das orientações e dos materiais no Ambiente Virtual de Aprendizagem (AVA) adotado na instituição - Moodle. 


\section{0 USO DE VIDEOAULAS}

0 advento das redes de alta capacidade em transmissão de dados e, principalmente, a implantação da tecnologia 4G na comunicação entre dispositivos móveis viabilizaram o meio para a transmissão de mídias mais pesadas (em termos de volume de dados), tais como os vídeos.

Na unidade curricular citada, a solução baseada em desenvolvimento de vídeos atendeu a uma redução da carga horária, porém também foi adequada ao perfil do público que consome e já é habituado a este tipo de mídia.

Tecnicamente, a solução se baseou em dois formatos de vídeo: a filmagem do professor, que focava a introdução do tema de cada conjunto de vídeos e a captura de telas com áudio do professor, descrevendo as doenças, como ilustram as imagem a seguir:

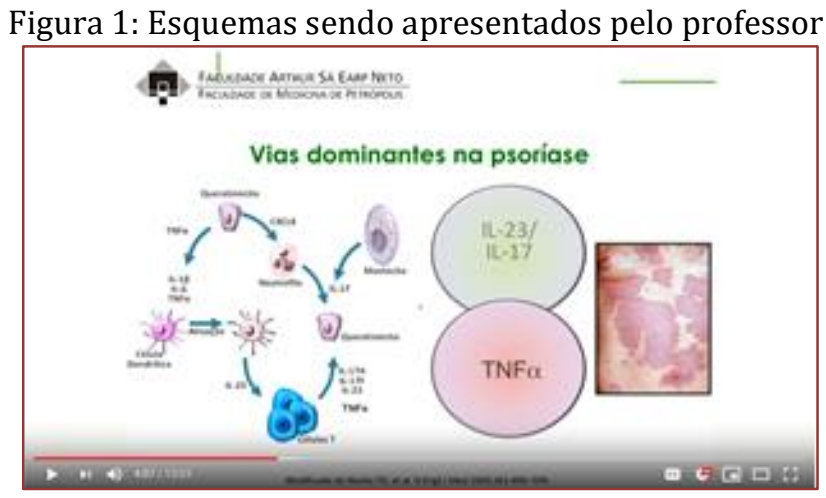

Fonte: videoaula sobre psoríase

Esta solução utilizou softwares gratuitos, necessitando como infraestrutura de hardware: uma câmera DSLR, Sony Alfa 5; cartões de memória formato SD; um notebook Dell; um microfone de lapela Greica.

Em termos de software, foram utilizados: Hit Film Express versão 11 para edição de vídeo; Audacity 2.2.1 para edição de áudio; AnyVideoConverter para a conversão de formatos de vídeo.

A escolha destes softwares não foi por acaso. No início do ano foi realizada oficina para os professores, na "semana de desenvolvimento docente", cujo objetivo era desenvolver e editar vídeos. Optou-se por versões gratuitas destes softwares, facilitando a adoção dos mesmos pelo professor.

Os vídeos eram editados logo após as filmagens e disponibilizados aos professores antes da publicação para revisão. Após a revisão e correções, quando foi o caso, os vídeos eram publicados aos alunos no AVA Moodle da instituição.

A publicação dos vídeos foi feita no Youtube, em vídeos não-listados. Houve também atenção especial em relação aos direitos autorais dos vídeos, processo devidamente documentado e acordado entre a Instituição e os professores-autores, com a participação do departamento jurídico

\section{RESULTADOS ALCANÇADOS}

O comprometimento e o profissionalismo dos professores possibilitaram a produção de mais de 40 videoaulas, em apenas 3 meses.

As estratégias possibilitaram:

- Sala de aula invertida, com o uso de videoaulas - mudança na "cultura" (docente e discente); maior autonomia ao estudante; acesso prévio ao conteúdo a ser discutido; possibilidade de revisitar os temas abordados.

- TBL adaptado às necessidades da unidade curricular - discussão contextualizada do conteúdo; estímulo ao trabalho em equipe; possibilidade de avaliação atitudinal e sedimentação do tema; opção para controle de frequência.

- Júri Simulado - discussão de tema de Ética Médica; possibilidade de ampliação das discussões. 
0 acesso às videoaulas, com um total de mais de 6.600 views, demonstram o engajamento dos estudantes e a aderência a este tipo de material de apoio.

Figura 2: Número de views por vídeo

\begin{tabular}{|c|c|c|c|}
\hline VIDEO & VIEWS & VIDEO & VIEWS \\
\hline CÂNCER OE PELE 1 & 154 & DERMATOZOONOSES 4 & 165 \\
\hline CÂNCER DE PELE2 & 124 & ECZEMAS 1 & 145 \\
\hline CÂNCER DE PELE 3 & 142 & ECZEMAS 2 & 157 \\
\hline COLAGENOSES 1 & 143 & HANSENIASE 1 & 235 \\
\hline COLAGENOSES 2 & 154 & HANSENIASE 2 & 170 \\
\hline COLAGENOSES 3 & 115 & HANSENIASE 3 & 165 \\
\hline COLAGENOSES 4 & 152 & MICOSES 1 & 228 \\
\hline COLAGENOSESS & 162 & MICOSES 2 & 172 \\
\hline COLAGENOSES 6 & 121 & MICOSES 3 & 187 \\
\hline DERMATITE 1 & 165 & MICOSES 4 & 186 \\
\hline DERMATITE 2 & 163 & PENFIGOS 1 & 12 \\
\hline DERMATITE 3 & 133 & PIOOERMITES 1 & 402 \\
\hline DERMATITE 4 & 138 & PIOOERMITES 2 & 243 \\
\hline DERMATITE 5 & 145 & PIODERMITES 3 & 196 \\
\hline DERMATOVIROSES 1 & 172 & PSORÍASE 1 & 163 \\
\hline DERMATOVIROSES 2 & 146 & PSORIASE 2 & 125 \\
\hline DERMATOVIROSES 3 & 140 & PSORIÁASE 3 & 110 \\
\hline \begin{tabular}{|l|} 
DERMATOVIROSES 4 \\
\end{tabular} & 116 & PSORIASE 4 & 104 \\
\hline DERMATOZOONOSES 1 & 246 & SíFILIS 1 & 175 \\
\hline DERMATOZOONOSES 2 & 193 & Sifius 2 & 131 \\
\hline DERMATOZOONOSES 3 & 179 & TOTAL & 6674 \\
\hline
\end{tabular}

$\left(^{*}\right)$ o vídeo sobre penfigos foi o último a ser incluído, quando este artigo foi escrito

A modalidade a distância, com o uso das estratégias relatadas, passou a ser adotada, também, pela unidade curricular de Dermatologia para atuar com as turmas de "dependência", o que favoreceu o estudo dos alunos, pela flexibilidade de horários e pelo acompanhamento a distância, podendo estes conciliarem a realização da dependência com as demais atividades.

Diversos professores da Instituição já entraram em contato com a Coordenação de Educação a Distância e, em parceria, começaram a desenvolver vídeos e outros objetos de aprendizagem. Estes professores, com visões distintas das necessidades das suas unidades curriculares, demandaram diferentes formasde colocar suas dinâmicas e materiais aos alunos.

Em Anatomia, o professor da unidade curricular enriqueceu os vídeos já gravados anteriormente com o "titling" dos conceitos que estavam sendo apresentados.

Em Fisiologia, animações estão sendo desenvolvidas para explicar o funcionamento dos néfrons.

A equipe de professores responsável pela unidade curricular Otorrinolaringologia está estudando formas de utilizar a realidade aumentada na compreensão das estruturas. Um professor da graduação de Odontologia se interessou pelo mesmo caminho.

\section{CONSIDERAÇÕES FINAIS}

A tecnologia deve ser considerada uma aliada - e não uma substituta - do professor, pois isso faz com que seja utilizada exatamente como aconteceu na experiência relatada, onde o seu uso possibilitou, inclusive o engajamento dos alunos nas mudanças ocorridas, já está familiarizado com o seu uso de ferramentas digitais.

Além do ponto positivo apontado acima, é importante ressaltar outros aspectos que contribuíram para o sucesso da experiência: 
- proatividade, disponibilidade, competência e não resistência a mudanças por parte da equipe de professores de Dermatologia;

- parceria entre os professores e a Coordenação de Educação a Distância, que compreendeu a necessidade e agilizou o processo de produção;

- apoio incondicional da direção, sempre atenta e pronta para as demandas da comunidade acadêmica;

- infraestrutura da IES, com estúdio de gravação, ambiente virtual de aprendizagem customizado e disponibilidade de ferramentas digitais a serviço do corpo docente e discente.

A junção desses aspectos possibilitou não só o sucesso como também o compartilhamento dessa experiência, servindo de modelo e de inspiração para os demais docentes da instituição.

\section{REFERÊNCIAS}

[1] Bannell, R.I. et. al. Educação no século XXI: cognição, tecnologias e aprendizagens. Petrópolis, RJ: Vozes; Rio de Janeiro: Editora PUC, 2016.

[2] Bergmann, J.; SAMS, A. Sala de aula invertida: uma metodologia ativa de aprendizagem. Rio de Janeiro: LTC, 2016.

[3] Brasil. Conselho Nacional de Educação. Câmara de Educação Superior. Diretrizes Curriculares Nacionais do Curso de Graduação em Medicina. Resolução $\mathrm{n}^{\circ}$ CNE/CES 3 de 20 de junho de 2014. Disponível em: <http://portal.mec.gov.br/index.php?option=com_content\&id=20138\&Itemid=866> Acesso em: 18 abr. 2019.

[4] Frank, J.R. The CanMEDS 2005 physician competency framework. Better standards. Better physicians. Better care. Ottawa: The Royal College of Physicians and Surgeons of Canada, 2005. Disponível em: <http://www.ub.edu/medicina_unitateducaciomedica/documentos/CanMeds.pdf> Acesso em: 27 abr. 2019.

[5] FMP - Faculdade de Medicina de Petrópolis. Projeto Pedagógico do Curso de Medicina. 2017.

[6] Freire, P. Pedagogia da autonomia: saberes necessários à prática educativa. São Paulo: Paz e Terra, 57ạ ed., 2016.

[7] General Medical Council. Tomorrow's doctors. 2009. Disponível em: <http://www.ub.edu/medicina_unitateducaciomedica/documentos/TomorrowsDoctors_2009.pdf> Acesso em: 27 abr. 2019.

[8] ISTE. International Society for Technology Education. ISTE Standards Students. 2016. Disponível em: http://www.iste.org/standards/for-students Acesso em: 20 abr. 2019. 


\section{Capítulo 12}

Percepção dos alunos do curso de Ciências Biológicas da Universidade Estadual do Ceará sobre os mecanismos de avaliação aplicados na Universidade

\section{Maria Elvira Silva de Sousa}

Francisca Amanda da Silva Martins

Amanda Mendes Gomes

Jeanne Barros Leal de Pontes Medeiros

Resumo: Este trabalho surge da experiência vivida na disciplina de Metodologia da Pesquisa Educacional ofertada no curso de Licenciatura em Ciências Biológicas, cujo objetivo principal a definição de uma questão de pesquisa para ser desenvolvida durante o semestre como exercício de formação. Desse modo, partindo de inquietações relacionadas ao curso de graduação, surgiu a seguinte pergunta: Como os estudantes do Curso de Ciências Biológicas percebem os métodos de avaliação na Universidade?. Tal questionamento permitiu observar de modo crítico e reflexivo a rotina dos discentes e a contribuição dos mecanismos de avaliação para os mesmos no âmbito acadêmico e na formação docente. Como resposta a pesquisa demonstrou que: a questão já era discutida em algumas pesquisas, por outras instituições e educadores, que também buscavam descobrir a influência destes mecanismos. No caminho para a construção do presente trabalho, pudemos nos aproximar de metodologias e instrumentos de pesquisa, que nos foi apresentado ao longo da disciplina. Foram realizados questionários com um aluno de cada semestre, tendo em vista o primeiro contato com os sujeitos da pesquisa, além de duas entrevistas com o objetivo de intensificar essa aproximação. Os resultados obtidos trazem dados das impressões dos discentes sobre as práticas avaliativas na universidade, do quanto é importante diversificar os métodos avaliativos e o quanto estes influenciam na formação de professores e que, consequentemente, poderão transformar como inúmeras outras pessoas percebem a educação como um todo.

Palavras-chave: Avaliação, Educação, Ensino superior, Pesquisa educacional, Formação docente. 


\section{INTRODUÇÃO}

No contexto acadêmico, a avaliação é considerada um tema polêmico pelas formas e objetivos que levam à sua aplicação. As práticas avaliativas são um assunto de grande importância, sejam elas tradicionais, objetivas, subjetivas, abertas (os alunos sugerindo como serão avaliados), orais ou até mesmo como instrumento para mensuração da conduta de uma pessoa. A avaliação atinge tanto o aluno como o professor, justamente por ser uma ferramenta para identificar problemas, progressos e pontos a serem trabalhados durante o processo ensino-aprendizagem (GALOCHA et al., 2017).

Dessa maneira, torna-se recorrente o questionamento sobre a efetividade desses métodos avaliativos por não conseguir englobar a variedade de concepções e habilidades de cada aluno, restringindo-se muitas vezes, a aplicações de provas de caráter tradicional que dependem principalmente da escolha do professor.

Segundo Melo e Urbanetz (2008), a avaliação deve envolver o todo, o aluno deve ser avaliado levando-se em conta seus conhecimentos, além da capacidade de criar e buscar o novo. Sendo assim, a pesquisa educacional é necessária para a compreensão do espaço acadêmico, que envolve tanto os docentes como os discentes, sem invalidar a pluralidade do saber, habilidades e experiências pessoais e coletivas (VASCONCELLOS et al., 2006). Por isso, ultimamente a literatura sobre a avaliação vem apontando na direção da transformação nas práticas avaliativas, tornando obsoleto o método de avaliação tradicional rumo a paradigmas emergentes que enfatizam a avaliação, sobretudo, em seus aspectos diagnósticos e formativos.

0 presente trabalho traz uma proposta de investigação que foi direcionada pela seguinte questão central: Como os estudantes do Curso de Ciências Biológicas percebem os métodos de avaliação na Universidade?

E justifica-se pela necessidade de avançar nas questões que envolvem a avaliação no Curso de Ciências Biológicas (CCB) e também nas reflexões sobre o tema, como professores em formação.

Sendo assim, o objetivo geral da pesquisa foi realizar uma análise da percepção dos alunos em relação às práticas avaliativas na Universidade, práticas estas que devem ser contínuas considerando a especificidade, devendo abranger no processo avaliativo não só o aluno, mas também o professor e o contexto (GALOCHA et al., 2017).

\section{METODOLOGIA}

A pesquisa foi realizada em um curso de Ciências Biológicas ofertado por uma Universidade estadual do nordeste brasileiro. Os sujeitos da pesquisa foram no total 10 estudantes de licenciatura, um aluno de cada semestre do curso, do $1^{\mathrm{o}}$ semestre ao 8o, escolhidos aleatoriamente para responder o questionário e dois para serem entrevistados. Como técnica de pesquisa optamos pelo questionário e pela entrevista. Com o propósito de coletar dados suficientes em prol da averiguação das diferentes percepções sobre as práticas avaliativas no ambiente acadêmico. Optamos pelo questionário, pois segundo Chaer e colaboradores (2011), um ponto positivo para adotá-lo como instrumento é, sem dúvida, o baixo custo deste, então, o questionário seria um democratizador da pesquisa.

Além disso, optou-se pela entrevista como método, pois segundo Fernandes (1991) ao realizar uma entrevista o pesquisador estabelece uma relação com os sujeitos da pesquisa. Os entrevistados foram discentes do primeiro semestre e do último semestre do $\mathrm{CCB}$, para que pudéssemos ter uma ideia do que se passa com o discente ao entrar no curso, logo no primeiro semestre, e ao final, quando passou por todas as avaliações durante cada semestre e suas opiniões e sugestões sobre elas.

- Pergunta 1: "Você sentiu grandes diferenças quanto aos métodos avaliativos empregados durante sua vida escolar e aqui na universidade?"

- Pergunta 2: "Como você vê a aplicação de outros métodos avaliativos diferentes das tradicionais provas escritas?"

- Pergunta 3: Para o aluno do primeiro semestre foi perguntado se este já tinha tido experiência em sala de aula, tendo de realizar algum tipo de avaliação. Para o aluno do último semestre, foi perguntado quais métodos avaliativos costuma utilizar (nos estágios, ou como docente) e como a sua formação influenciou neste quesito. 
Nesse sentido, a partir dos questionamentos discutidos durante cada abordagem analisamos, comparamos e discutimos as percepções de cada sujeito entrevistado. Os dados foram analisados por meio do Software Google Forms ${ }^{\circledR}$, sendo bastante relevantes para a organização e interpretação dos dados.

\section{DESENVOLVIMENTO}

A trajetória deste trabalho deu-se com o início da disciplina de Metodologia da Pesquisa Educacional, pela qual, a cada aula nos era apresentado algo sobre a construção de um artigo relacionado a educação. Com isso, houve a solicitação para se preparar um estudo situado no âmbito educacional, ao longo de alguns meses entre as aulas teóricas, pesquisas e investigações sobre o projeto, o resultado final nos deu um panorama do que é compartilhado pelos alunos do curso.

A maioria dos jovens que entram nas universidades vêm de uma realidade em que não há tanto estímulo à construção do conhecimento e à pesquisa. E no ensino superior há grande dificuldade em lidar com o fato de que as atividades não vêm mais prontas e que o aluno, até então mero ator, encenando aquilo que lhe era determinado, precisa passar a ser também autor de sua história acadêmica, participando da elaboração do conhecimento e da produção das atividades que até mesmo, o avaliarão. E foi está a proposta da disciplina, quando nos colocou como protagonistas, com o intuito de formar pesquisadores (CHAER, 2011).

Analisar o processo avaliativo é importante para o presente trabalho, pois a legislação educacional (LDB 9394/96), contempla em seu texto a avaliação contínua e cumulativa com prevalência dos aspectos qualitativos sob os quantitativos, tendo em vista que muitos alunos chegam ao curso superior com carência de domínios de conteúdos básicos e necessários ao desenvolvimento esperado (VITO; SZEZERBATZ, 2017).

A avaliação da aprendizagem deve assumir o desafio de considerar de modo simultâneo todos os componentes no qual surgem ao longo do seu desenvolvimento. Desse modo, ao avaliar, o professor deverá coletar, analisar e sintetizar, da forma mais objetiva possível, as manifestações das condutas cognitivas e afetivas dos alunos, produzindo um apanhado do que foi aprendido. Atribuindo uma qualidade a essa configuração da aprendizagem, posteriormente, decidindo as devidas condutas docentes e discentes com base nessas informações (LUCKESI, 1991).

\section{RESULTADOS E DISCUSSÃO}

A partir das informações adquiridas por meio da aplicação dos 8 questionários e das 2 entrevistas, a pesquisa indicou semelhanças referentes às impressões dos discentes do Curso de Ciências Biológicas sobre as práticas avaliativas da universidade, como também consideramos determinadas opiniões bastante diferentes no decorrer das averiguações alcançadas.

Como resposta à indagação sobre o uso das avaliações de cunho objetivo no aprendizado, houve um equilíbrio entre as opiniões dos 8 alunos dos diferentes semestres avaliados, pois metade deles sente-se satisfeita $(50 \%)$, e por outro lado, a outra metade $(50 \%)$ dos estudantes não se sente devidamente avaliada por tal método.

Para Hoffmann (2002) o processo avaliativo não deve estar centrado no entendimento imediato dos conceitos estudados pelos alunos (sendo este um fator comum nas provas de caráter objetivo), ou até mesmo no entendimento de todos de modo equivalente. Justamente, pelo fato de que cada pessoa possui um ritmo único e particular no processo de aprendizagem.

Quanto ao questionamento sobre a utilização simultânea de métodos avaliativos de cunho objetivo e subjetivo pelo docentes, a maior parte dos pesquisados (62,5\%), mostrou que essas avaliações contribuem sim de maneira positiva para o aprendizado.

A avaliação subjetiva (dissertativa) busca uma maior profundidade do conhecimento, sendo esta eficaz no sentido de avaliar o raciocínio lógico dos alunos, a organização de ideias e a clareza de expressão. A avaliação objetiva possibilita uma verificação ampla do conteúdo, sendo este um método rápido e prático. 
Contudo, essa estratégia não avalia de modo eficaz a habilidade de expressão do aluno, além da sua difícil elaboração. Desse modo, percebe-se que o alinhamento entre os dois métodos avaliativos traz resultados satisfatórios (ZEFERINO; PASSERI, 2007).

A pergunta 3, questionou se as avaliações de caráter oral podem ser consideradas mais eficazes no processo de aprendizagem. Uma parte significativa dos estudantes (75\%) mostrou que sente maior eficácia nas avaliações orais (seminários, debates em grupo etc.). Evidenciando que a maioria aprova uma mudança nos frequentes hábitos de avaliação para algo mais flexível, além da avaliação escrita.

O objetivo dessa avaliação deve ser direcionado não somente no conhecimento adquirido pelo estudante (habilidades cognitivas), mas também nas áreas psicomotoras e afetivas obtidas por ele durante toda a vida. A avaliação bem planejada é eficaz no cumprimento de suas funções, leva em conta os objetivos educacionais específicos de cada etapa da formação, de acordo com perfil final desejado de habilidades e competências (PANÚNCIO-PINTO; TRONCON, 2014).

Na pergunta 4, objetiva, mas com justificativa de resposta, indagou como o estudante avalia as práticas avaliativas elaboradas pelos docentes no ensino superior. Mais de $62 \%$ dos estudantes mostraram que as avaliações feitas pelos docentes do curso são razoáveis, pois em uma justificativa feita por um aluno do $2^{\underline{0}}$ semestre mostra que "Alguns professores cobram provas extremamente difíceis de conteúdo que algumas vezes não são ministrados e os prejudicam”, eles não se sentem bem avaliados pelo mesmo e são prejudicados tirando notas baixas no fim da disciplina. "Cada professor tem um método. Mas aprecio as metodologias que dão mais autonomia aos alunos", disse um estudante do $4^{\circ}$ semestre, que completou "e como futuros profissionais da educação a autonomia em sala desde a universidade é de fundamental importância para aprendizagem dos alunos".

Segundo Oliveira e Santos (2005), não há um consenso entre os que pesquisam a avaliação da aprendizagem. Parece haver um descontentamento em relação aos métodos avaliativos, sendo que os discursos, em sua maioria, tendem a vitimizar o aluno, colocando-o como agente passivo no processo da avaliação. 0 professor, por sua vez, é considerado o sujeito do poder que determina, sem consultas, como ocorrerá a avaliação. 0 contrário do que foi feito durante a disciplina, em que foram empregadas metodologias ativas, onde os estudantes participaram de todo o processo de aprendizagem, construindo as avaliações, juntamente com a professora da disciplina.

Quanto à indagação de quais modelos de avaliação apresentados pelos professores eram mais efetivos no aprendizado individual do aluno, dois métodos de avaliação se destacaram: Avaliação objetiva e subjetiva $(62,5 \%)$, e a oral (50\%), que mostram o quanto o aluno aprendeu e pode defender seu ponto de vista das mais variadas formas, não só de uma maneira tradicional como é mais usada.

Almeida (1992) e Martins (1999) observam que a avaliação no ensino superior está relacionada às experiências tradicionais que classificam o estudante, e que os docentes apresentam dificuldades em ser coerentes quanto ao tipo de avaliação. A classificação torna-se inevitável, pois segundo Oliveira e Santos (2005) não haveria parâmetros para se comparar os desempenhos. Sugere-se, que a avaliação seja utilizada não somente visando mensurar o desempenho do aluno, mas também como uma perspectiva de prognóstico com o objetivo final de orientar o estudante na melhor forma de aprimorar seu conhecimento (HADJI, 1994). Isto refere-se justamente ao que foi colocado pelos sujeitos desta pesquisa, no ponto em que falam da importância desta orientação para sua formação como docente.

Na pergunta 7, pedimos a opinião dos estudantes, para sabermos se seminários e trabalhos são recursos que promovem uma melhor aprendizagem do conteúdo, e $100 \%$ responderam que sim. Recursos usados, que fogem ao tradicional, são os que melhor se encaixam para uma aprendizagem significativa, pois de acordo com um aluno do 6ํㅗ semestre: "Quando vamos explicar um conteúdo nos preparamos, inclusive para possíveis perguntas. Isso motiva o aluno a buscar informações, às vezes até trazendo curiosidades".

Segundo Borba e colaboradores (2007), não há como se basear totalmente ou restringir somente de avaliações objetivas (como a prova). É recomendável que o docente varie seus instrumentos, como: provas escritas/orais/práticas, relatórios, seminários, estudos de caso, projetos, resumos, exercícios, e outros, que dependendo dos objetivos de aprendizagem estabeleça ao docente uma comunicação mais efetiva com seus alunos e mostre o andamento do processo de aprendizagem. 
As perguntas subjetivas, questionaram as opiniões dos alunos sobre a importância desses recursos avaliativos como parte do seu processo de formação como licenciado e pediram sugestões viáveis para serem aplicadas nos processos de avaliações do Curso de Ciências Biológicas

Como resultado da entrevista realizada com alunos do primeiro e do último semestre foi possível observar que para o entrevistado 1 , com relação às diferenças dos métodos avaliativos empregados na escola e na universidade, não há diferença considerável entre a experiência avaliativa vivida na escola ou na universidade.

Nesse caso, vale ressaltar que o entrevistado se encontra no primeiro semestre do curso. Desse modo, ele mencionou que, na maioria das cadeiras cursadas até o momento, o principal mecanismo de avaliação têm sido as provas ditas como tradicionais. Ademais, o mesmo também citou que determinados professores tinham em mente empregar a apresentação de seminários como prática avaliativa para os alunos deste semestre.

Quando perguntado sobre a utilização dos métodos avaliativos diferentes dos tradicionais. 0 entrevistado comentou sobre a necessidade dos diferentes métodos avaliativos para a melhor compreensão do aprendizado do aluno, no sentido de analisar não só as habilidades de escrita, mas também de expor de um modo prático o que o discente conseguiu aprender e que ainda não teve a oportunidade de ser avaliado por meio desses recursos alternativos, que comumente "fogem do padrão". Ele também citou que talvez tais métodos o favorecessem em determinados pontos, que ele considera ter experiência. $\mathrm{E}$ comentou que nem sempre conseguia ter um bom rendimento quando avaliado somente por provas escritas, por isso afirmou que a utilização simultânea dos recursos alternativos e tradicionais seriam mais efetivos, possibilitando um melhor desempenho dos alunos e as suas diferentes habilidades.

Quando perguntado se já havia tido experiências em sala de aula e se já tinha elaborado algum tipo de avaliação, ele respondeu que já havia atuado como monitor no laboratório da escola, durante o ensino médio, mas não ministrava aula. A sua tarefa básica era ajudar os outros alunos com possíveis dúvidas e com o repasse de informações sobre o projeto que estava sendo trabalhado no laboratório. Porém, ele não realizava nenhuma prática avaliativa com os outros alunos.

Pela fala do entrevistado 2, aluno do último semestre do curso de Licenciatura, pode-se perceber que em sua vivência escolar o principal recurso avaliativo empregado resumia-se a provas objetivas ("avaliações de marcar") e que durante o primeiro semestre do Curso de Licenciatura em Ciências Biológicas essa forma de avaliar persiste na universidade. Porém, ao longo dos semestres, percebe-se uma alternância quanto o uso das práticas avaliativas de caráter tradicional e alternativo.

Como contribui Datrino e colaboradores (2010), os recursos avaliativos empregados nas escolas desdobram-se de concepções das quais, os professores e alunos, muitas vezes sequer conhecem seus fundamentos. O sistema educacional propõe uma avaliação classificatória, onde são avaliadas características isoladas, por exemplo um aluno responde melhor a uma avaliação tradicional e outro não responde tão bem e este é cada vez mais excluído do processo de escolarização desde a escola até a universidade, onde os métodos persistem.

0 pesquisado ressalta que a utilização de métodos alternativos é extremamente válida, pois amplia compreensão dos alunos sobre temas da área de Ciências Biologia e desenvolve habilidades e competências fundamentais ao licenciado em Ciências Biológicas. Em sua fala fica evidente que o processo de ensino aprendizagem se torna menos enfadonho, e, portanto, é positiva a inserção dos variados métodos de avaliação como, por exemplo, rodas de discussão, seminários, aulas invertidas e dentre outras práticas que favorecem consideravelmente o seu desempenho.

Quanto aos métodos avaliativos que costuma utilizar (nos estágios, ou como docente) e como a sua formação influenciou neste quesito, ele informou que costuma trabalhar com métodos avaliativos de cunho alternativo (apresentação de trabalhos, atividade pesquisada, produção de modelos didáticos e outros) nas suas aulas, buscando sempre variar as metodologias. Dessa maneira, o mesmo comentou que a aplicação de provas só ocorre em último caso, essa prática de formação tem sido positiva, pois leva outros professores a inovar em suas aulas.

E como corrobora Hoffman (2010), refletir a concepção de avaliação é modificar as práticas de ensino e aprendizagem, de educação e de escola, apoiadas em princípios e valores comprometidos com a instituição e com a formação do aluno cidadão. 
Quando isso for colocado em prática, a avaliação será vista como transformadora da realidade escolar.

\section{CONSIDERAÇÕES FINAIS}

Quando nos foi proposto o desafio da pesquisa no ramo da educação parecia algo extremamente complexo, pois este caminho era muito diferente ao que já estávamos habituadas, quando comparadas as pesquisas puramente quantitativas com que já tivemos oportunidade de trabalhar, mas o que parecia algo difícil foi sendo desmistificado com o passar do tempo em que trabalhávamos no projeto, e assim, vimos o quão interessante e inovador ela é, pois se preocupa não só com os números que levarão aos resultados, mas sim todo o processo, o contexto e as opiniões relacionadas ao sujeito da pesquisa, ele passa de apenas números e se torna o real sentido do que se estuda.

Durante o processo de entrevistas e aplicação dos questionários, lidamos com opiniões das mais diversas dos nossos colegas de curso dos mais variados semestres, e em muitos momentos nos identificamos com suas opiniões e justificativas, e isso foi uma oportunidade para uma reflexão em cada uma de nós, em como mudar essa realidade dentro da universidade e em nossas futuras salas de aula.

Além disso, nos abre uma nova perspectiva relacionada a uma maior flexibilidade nas avaliações aplicadas pelo Curso de Ciências Biológicas (CCB/CCS), já que de acordo com os resultados obtidos, a maioria dos alunos se sente melhor avaliado quando há uma integração entre os diversos métodos de avaliações existentes, que já são aplicados por alguns professores do curso, mas outros ainda não começaram essa abordagem, seguindo na mesma linha do que nos é proposto nos ensinos fundamental e médio.

A partir dos resultados obtidos por intermédio deste trabalho de pesquisa chegamos à conclusão do quanto é importante considerar as opiniões e sugestões de cada aluno, que compõem o Curso de Ciências Biológicas da Universidade Estadual do Ceará a respeito dos métodos avaliativos, pois isto fará parte da formação deste aluno, como futuro professor e refletirá na formação de nossos alunos e assim por diante.

Além disso, abre perspectivas para estudos mais aprofundados sobre avaliação no contexto universitário brasileiro, como contribuição para possíveis mudanças de paradigma entre os cursos de licenciatura.

\section{REFERÊNCIAS}

[1] Almeida, A. M. F. P. M. Um estudo sobre a avaliação da aprendizagem em um curso superior de ciências agronômicas. Tese de Doutorado. Faculdade de Educação da Universidade Estadual de Campinas, Campinas, 1992.

[2] Borba, A. M. de; Ferri, C.; Hostins, R. C. L. Avaliação da aprendizagem no ensino superior: questões que emergem da prática docente. Contrapontos, Itajaí. v. 7, p. 43-54, 2007.

[3] Chaer, G.; Diniz, R. R. P.; Ribeiro, E. A. A técnica do questionário na pesquisa educacional. Evidência, Araxá. v. 7, n. 7, p. 251-266, 2011.

[4] Datrino, R. C.; Datrino, I. F.; Meireles, P. H. Avaliação como processo de ensino-aprendizagem. Revista de educação, Valinhos. v. 13, n. 15, p. 27-44, 2010.

[5] Fernandes, M. E. Memória Camponesa. Anais da 21a Reunião Anual de Psicologia, SPRP, Ribeirão Preto, p. 20, 1991.

[6] Galocha, C.; Poleto, S.S.; Tavares, M. Avaliação no ensino superior: paradoxos e desafios. Revista @mbienteeducação. Universidade Cidade de São Paulo. v. 10, n. 1, p. 25-35, 2017.

[7] Hadji, C. A avaliação, regras do jogo das intenções aos instrumentos. 4.ed. Portugal: Porto Editora, 1994.

[8] Hoffmann, J. M. L. Avaliar para Promover - as setas do caminho. Porto Alegre: Mediação, 2002.

[9] Hoffmann, J. M. L. Avaliar: respeitar primeiro, educar depois. 2.ed. Porto Alegre: Mediação, 2010.

[10] Luckesi, C. C. Avaliação da aprendizagem escolar: apontamentos sobre a pedagogia do exame. Tec. Educ. v. 20, n. 101, p.82-86, 1991.

[11] Melo, A.; Urbanetz, T. S. Fundamentos da Didática: Curitiba: Ibpex, 2008.

[12] Martins, R. C. Avaliação crítica de uma experiência de ensino aprendizagem. Estudos de Psicologia - PUC Campinas. v. 16, n. 2, p.54-64, 1999.

[13] Oliveira, K. L. de; Santos, A. A. A. dos. Avaliação da aprendizagem na universidade. Psicol. esc. educ., Campinas, v. 9, n. 1, p. 37-46, jun. 2005. 
[14] Panúncio-Pinto, M. P.; Troncon, L. E. Avaliação do estudante - aspectos gerais. Medicina (Ribeirao Preto. Online), v. 47, n. 3, p. 314-323, 3 nov. 2014.

[15] Vasconcellos, M. M. M.; Oliveira, C. C. de; Berbel, N. A. N. O professor e a boa prática avaliativa no ensino superior na perspectiva de estudantes. Interface, Botucatu. v. 10, n. 20, p. 443-456, 2006.

[16] Vito, D. Z.; Szezerbatz, R. P. A avaliação no ensino superior: a importância da diversificação dos instrumentos no processo avaliativo. Educere - Revista da Educação, Umuarama, v. 17, n. 2, p. 221-236, 2017.

Zeferino, A. M. B; Passeri, S. M. R. R. Avaliação da Aprendizagem do Estudante. Cadernos da ABEM, v. 3, p. 39-43, 2007. 


\title{
Capítulo 13
}

\section{Proposta para a utilização de softwares de modelagem e simulação no curso de Engenharia de Produção Curitiba, Parana, Brasil/Pr Abril/2019}

\author{
Douglas Soares Agostinho \\ Marcos Wurzer \\ Vitor Hugo Lopes Lau
}

Resumo: A maioria das instituições de ensino tem sofrido grandes transformações, notadamente a partir do surgimento da referida geração "Z", a qual surgiu a partir de 1990 e foi a primeira geração que não passou por uma migração digital, assumindo no seu dia a dia grande apelo com a conectividade e o uso intensivo de tecnologia.

0 presente artigo tem como objetivo a partir da constatação da alteração das demandas tanto pelo mercado profissional como dos próprios estudantes, apresentar uma solução alinhada e de fácil implementação. Importante destacar também a necessidade de se encontrar uma solução que se adapte tanto no ensino presencial, como nas modalidades semipresenciais e à distância (EAD).

Outro ponto importante a ser destacado é a necessidade de se cumprir as Diretrizes Curriculares Nacionais (DCNs) da Engenharia, onde o foco na atividade prática é de vital importância na formação do engenheiro nos dias de hoje. Com isso a nossa Instituição de Ensino (IES), buscou no mercado o que de melhor existia em termos de simuladores industriais e após análise dos prós e contras em alguns softwares disponíveis, decidiu por um que propicia ao aluno, desde o seu primeiro dia de aula simular situações reais de seu cotidiano e ao longo do curso ir melhorando cada vez mais até o ápice do desenvolvimento de um novo processo, reproduzindo o mesmo em 3D com alternativas diversas que envolvem desde o arranjo físico, variação do "takt time", gasto com energia, preocupação com meio ambiente até o cálculo do custo de fabricação de um determinado produto. Nossa IES iniciou esse trabalho no curso presencial e devido a sua praticidade e manuseio, logo transportou essa tecnologia para as demais modalidades desenvolvidas no curso de Bacharelado em Engenharia de Produção.

Com uso de tutoriais, desenvolveu vários estudos de caso e aplicou em algumas disciplinas base do curso, tais como: Introdução à Engenharia, Mapeamento de Processos, Tempos e Métodos, Projeto de Fábrica e Arranjo Físico e devido ao sucesso o expandiu para outras disciplinas do curso com o intuito de formar profissionais cada vez mais preparados para o mercado e ou empreender em negócio próprio.

Com isso pode-se evidenciar as atividades práticas a serem apresentadas para que se alinhem às exigências de evidências apresentadas pelo Ministério da Educação (MEC), pelos respectivos Conselhos Regionais de Engenharia e até mesmo pelo mercado que vai demandar os profissionais formados em Engenharia de Produção. 


\section{INTRODUÇ̃̃OO}

A evolução tecnológica que a educação está assumindo nos últimos anos, tem lançado grandes desafios para as instituições de ensino que atuam nas áreas da engenharia seja qual for a modalidade de ensino, inclusive com a mudança de paradigmas do professor, que a cada dia exige do mesmo uma atitude mediadora entre o ensino e a aprendizagem.

A oferta de laboratórios nas diferentes disciplinas vem possibilitando a mescla de disciplinas teóricas e práticas, e estão contribuindo em muito com a formação dos estudantes, lhes proporcionando competências e habilidades alinhados com o perfil do egresso previsto no plano dos cursos, o qual atende às demandas do mercado de trabalho no segmento tecnológico.

A disponibilização de softwares de modelagem e de simulação é de vital importância no Planejamento Pedagógico dos Cursos (PPC) e serve como um diferencial importante na formação do profissional que poderá alinhar seus conhecimentos teóricos com a vivência prática tão desejada pelas diferentes organizações que atuam nos segmentos tecnológicos e procuram por profissionais qualificados.

A questão que fica é de como aplicar estas atividades práticas fora do ambiente da instituição de ensino, permitindo que o estudante dê continuidade ao seu aprendizado de modo assíncrono em oposição às aulas formais, permitindo uma formação mais proativa, descompromissada com as ementas regulares de cada disciplina do seu curso?

Importante também agregar a este questionamento uma provocação importante: Como levar esta vivência prática para as modalidades semipresenciais e à distância (EAD), em um curso de graduação?

As modalidades à distância e/ou semipresencial fazem parte de uma tendência cada vez mais demandada atualmente, pois está abrindo um mercado importante para o oferecimento de ensino/aprendizagem além do ambiente físico presencial, atingindo pessoas interessadas na sua formação profissional e que não contam em suas regiões com instituições que possam oferecer a flexibilidade de aprendizado, fora da limitação de um currículo elaborado para uma formação síncrona que exige um ambiente físico com verificação tradicional de frequência e avaliação, paradigma este que está sendo quebrado por muitas instituições de ensino com abrangência nacional e internacional.

O objetivo do presente artigo é identificar as contribuições do uso de software de modelagem e simulação para o curso de Engenharia de Produção, trazendo um modelo educacional que se alinhe como mediador nas relações de ensino-aprendizagem, aproximando cada vez a teoria à prática que o futuro profissional enfrentará no mercado.

Caracteriza-se como justificativa a realidade atual vivida também na área da educação com as tecnologias avançando dia a dia. É necessário que o profissional esteja sempre antenado a tudo que ocorre no mundo e que as tomadas de decisão sejam as mais rápidas e precisas, afinal uma decisão equivocada pode levar ao fracasso de um produto e até de uma empresa. Com base nisso, o uso de simuladores está cada vez mais presente nas empresas, onde o engenheiro pode fazer uma série de testes em ambientes virtuais sem interferir no andamento do processo normal e depois que se chegou ao melhor modelo a ser adotado e então reproduzir tal modelo na produção e ter certeza que funciona. Um exemplo disso estamos vendo no conceito da indústria 4.0 onde tudo deve funcionar de maneira planejada, usando Inteligência Artificial, Realidade Virtual e outras ferramentas em prol de melhoria dos processos, redução de custos e diferencial competitivo.

A vantagem do uso de software de simulação é que pode-se reproduzir em ambiente virtual a realidade do processo atual em uso e em cima disso propor soluções, alterações e verificar o resultado e com isso conseguir o melhor possível, assim como, planejar um novo processo, uma nova linha de montagem e só partir para o real após esgotado todo o potencial de análise.

\section{REFERENCIAL TEÓRICO}

A maioria das formas tradicionais de se ensinar, já não se alinham mais com as demandas do mercado educacional em decorrência da evolução tecnológica e o surgimento da geração definida com "Z" de "zapear" e também conhecida como geração "F" de Facebook, redefinição está destacada por Heredia (2010) em seu blog onde discutiu sobre conflito de gerações.

Ao contrário das gerações anteriores, ou seja, os Baby Boomers e as gerações X e Y, os nascidos a partir de 1990 não viveram a migração digital, pois já nasceram literalmente conectados e vivem o seu dia a dia sob 
o ponto de vista dos dispositivos móveis e com acesso a toda a informação na velocidade da fibra ótica que gira pelo mundo através da internet.

De acordo com Moram (2004, p.11), “o campo da educação está muito pressionado por mudanças, assim como acontece com as demais organizações". Assim as ferramentas tecnológicas passam a ser um recurso poderoso, mas deve estar muito alerta com a facilidade da mudança de foco por parte do estudante em decorrência da facilidade de se trocar de telas com um simples movimento de dedos.

A pedagogia definiu no passado um limite para as aulas formais com máximo cinquenta minutos para a concentração produtiva para o aprendizado. Atualmente as rotas instrucionais utilizadas pela nossa IES tem se utilizado de etapas de ensino de cerca de 10 minutos, realizando uma aula com limite de 5 temas, ou seja, 50 minutos, instigando o aluno a manter seu foco nos temas trabalhados, atenuando assim a probabilidade da busca por conteúdo fora do proposto para uma aula formal.

Segundo KENSKI (2016, p. 19) "as tecnologias invadem nossas vidas, garantem novas possibilidades de bem-estar e fragilizam as capacidades naturais do ser humano" e cabe portanto a instituição de ensino ampliar seu leque de recursos didáticos práticos, anteriormente restritos a aulas em laboratórios físicos que além de representarem um elevado investimento, são capazes de atender apenas a formação de alunos de cursos presenciais e semipresenciais, mas mesmo neste caso correndo um grande risco de transformar estes encontros numa solução de continuidade das aulas teóricas formais, mantendo a sincronicidade do estudo.

Uma solução para garantir a formação assíncrona é a utilização de simuladores e modeladores, com capacidade e recursos 3D. 0 simulador adquirido e em uso em nossa IES, é o simulador da FlexSim, o qual, apresenta em seu manual a contribuição dos simuladores e modeladores no processo de formação acadêmica e apresenta como referência a definição de simulação com base em Seila (1995, p.7-15): "É a representação da dinâmica de um objeto ou sistema para análise de alguma atividade deste, considerada muito grande e/ou complexa".

Ainda neste manual de treinamento, a FlexSim afirma que a simulação permite uma tomada de decisão com boa previsibilidade de dados e replica o funcionamento do sistema em um ambiente:

- Livre de riscos;

- Para testes diversos;

- $\quad$ Com possibilidade de análises entre diversas variáveis.

\section{PROCEDIMENTOS METODOLÓGICOS}

A pesquisa pela melhor solução em modelagem e simulação pode ser considerada exploratória e partiu da necessidade de se adotar um software de modelagem e simulação para evidenciar as atividades práticas das diferentes disciplinas do curso, surgiu a partir de uma demanda apresentada pela Comissão do MEC durante a avaliação de Reconhecimento do curso presencial de Engenharia de Produção. Entendendo a importância desta solicitação não só na modalidade presencial, mas também nas modalidades semipresencial e EAD, a direção da instituição atendeu prontamente à solicitação de um investimento emergencial para a aquisição de licenças de um software de simulação e modelagem tanto no ambiente acadêmico como em atividades nas áreas industrial, comercial e de serviços.

Foram identificados os principais fornecedores disponíveis no mercado e foram priorizadas a capacidade de atendimento, a amplitude de variáveis que podem ser simuladas, a tecnologia utilizada, o suporte de treinamento e acompanhamento oferecido ao cliente e a flexibilidade do software para uso acadêmico e após análise da matriz de correlação entre os atributos definidos, a IES decidiu pela solução apresentada pela FlexSim Brasil, disponível em https://www.flexsim.com/pt/ .

Dentre os aspectos avaliados para a decisão de qual software usar, segue abaixo uma lista deles:

I. Custo / benefício das licenças oferecidas para uso residente nos laboratórios da instituição (Presencial e Semipresencial);

II. Liberação do uso de licenças para a sua adoção pelos alunos em atividades práticas em suas residências ou nos polos presenciais do EAD, localizados regionalmente de acordo com a matrículas dos alunos;

III. Oferecimento de treinamento específico para toda a equipe de professores da instituição;

IV. Suporte técnico acessível em alcance regional via fórum gerenciado pelo suporte técnico da empresa; 
V. Amplo portfólio de fornecimento para instituições de ensino e empresas nos países onde a empresa atua presencialmente;

VI. Ambiente 3D de fácil compreensão e utilização pelo estudante;

VII. Possibilidade de extensão da utilização do software na área de pesquisa e extensão acadêmica;

VIII. Fornecimento gratuito de material didático e softwares em versão Beta para a adoção paralela, dando maior flexibilidade de atuação e aprendizado;

IX. Capacidade de utilização com dispositivos de realidade virtual, trazendo maior atratividade tecnológica à utilização nas simulações e modelagens.

Veja no quadro abaixo a comparação entre softwares avaliados para cada item acima destacado:

QUADRO 1: ANÁLISE COMPARATIVA ENTRE OS SOFTWARES AVALIADOS
\begin{tabular}{|c|c|c|c|}
\hline Item & Fornecedor A & Fornecedor B & Flexsim \\
\hline I. & Alto & Médio & Médio \\
\hline II. & Sim & Não & Sim \\
\hline II. & Sim & Sim & Sim \\
\hline V. & Sim & Sim & Sim \\
\hline V. & Não & Sim & Sim \\
\hline VI. & Não & Não & Sim \\
\hline II. & Sim & Não & Sim \\
\hline II. & Não & Não & Sim \\
\hline X & Não & Sim & Sim \\
\hline
\end{tabular}

\section{DESENVOLVIMENTO DO USO DO SIMULADOR EM DISCIPLINAS ESPECÍFICAS}

Com base nas condições apresentadas no quadro 1, já no início de 2019 a aquisição das licenças e a efetivação do treinamento acordados foram cumpridos e em seguida foi realizada uma reunião junto aos professores, e foi definido em quais disciplinas no presencial e o quais recursos do simulador seriam aplicados em cada uma delas, dando início assim ao uso do simulador em forma global no curso de Engenharia de Produção Presencial e com essa aplicação e desenvolvimento, alguns ajustes se fizeram necessários e na fase posterior já foram implantados nas disciplinas das modalidades Semipresencial e EAD.

Considerando os ciclos definidos no PPC do curso de Engenharia de Produção, com o referendo do Colegiado do Curso e do Núcleo Docente Estruturante, foram definidas as disciplinas como piloto para a implantação do Simulador e Modelador FlexSim nas suas atividades práticas, tanto no ensino presencial, semipresencial e no EAD:

A. Introdução a Engenharia da Produção

- $\quad$ Apresentação do software;

- Orientações para download e instalação;

- Contextualização;

- $\quad$ Apresentação de um modelo de linha de produção;

- Modelagem e simulação;

- $\quad$ Apresentação e discussão das melhorias obtidas.

B. Manufatura Enxuta

- $\quad$ Apresentação do software;

- Orientações para download e instalação;

- Contextualização;

- $\quad$ Apresentação de um modelo de linha de produção empurrada (Just in Case); 
- Modelagem e simulação;

- Apresentação e discussão da proposta para produção puxada (Just in Time).

C. Projeto do Lay Out de Fábrica

- $\quad$ Apresentação do software;

- Orientações para download e instalação;

- Contextualização;

- $\quad$ Apresentação de um modelo de linha de produção puxada (Just in Time);

- Modelagem e simulação;

- Apresentação e discussão da proposta para redução de desperdícios e adequação do arranjo físico.

\section{APRESENTAÇÃO E DISCUSSÃO DOS RESULTADOS}

\subsection{DEFINIÇÃO DE DISCIPLINAS E CRONOGRAMA DE IMPLANTAÇÃO}

Para a implantação do piloto foi elaborada uma simulação simples representada na figura 1 para que os alunos a reproduzissem na versão livre do software, permitindo a realização da atividade prática à distância.

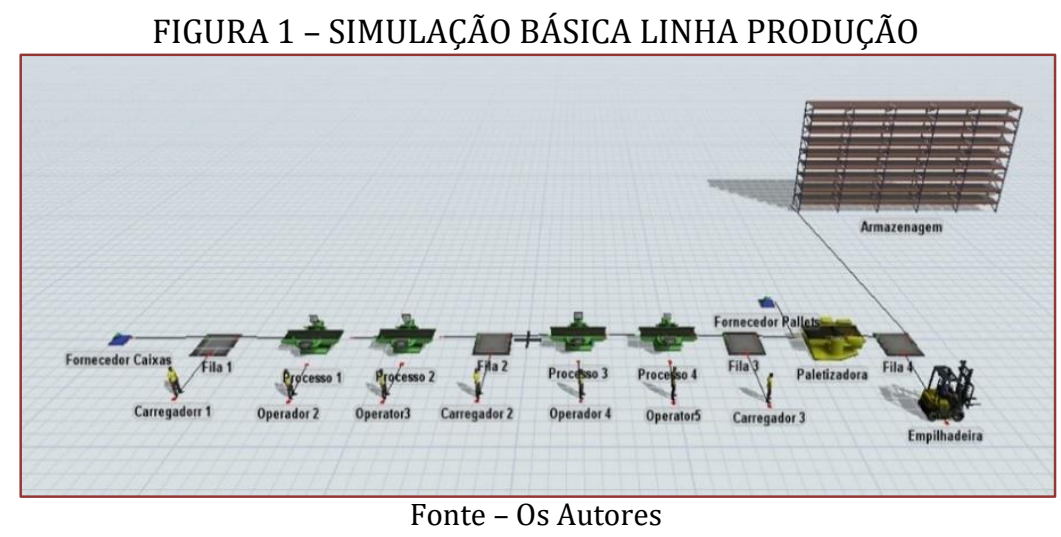

Para a devida contextualização da atividade, foram elaboradas três vídeo-tutorias para serem hospedadas no Ambiente Virtual de Aprendizagem - AVA:

- Vídeo 1: Orientações para realizar o download do software diretamente do site do fornecedor;

- Vídeo 2: Orientações para a instalação e configuração do software;

- Vídeo 3: Tutorial com a apresentação das funcionalidades do software e com as orientações para a reprodução da simulação e encaminhamento para a análise do gargalo de produção e a apresentação de uma ação de melhoria do processo.

Apesar da simplicidade da simulação inicial representada na figura 2, seguramente serve de base para a ambientação da simulação 3D proposta pelo software e a identificação de grandes oportunidades de utilização futuras simulações mais alinhadas com a realidade das atividades profissionais da Engenharia de Produção. 


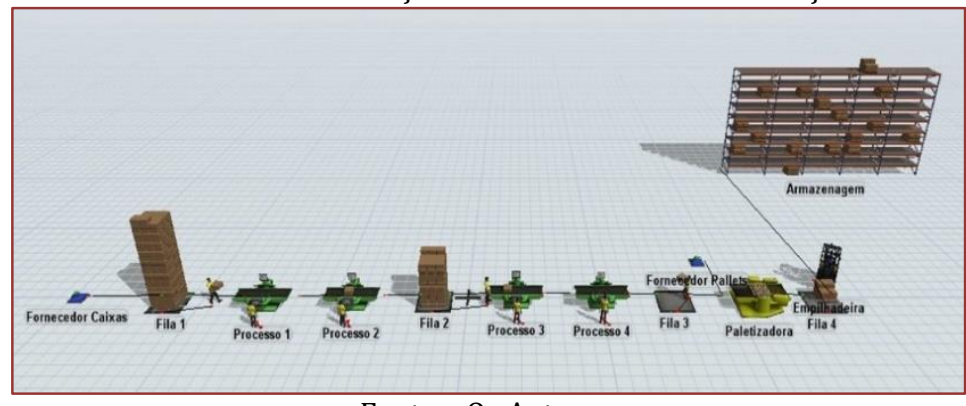

Fonte - Os Autores

Para a implantação da utilização definitiva da simulação 3D, foi estabelecido um cronograma de implantação desde o primeiro módulo do curso presencial, semipresencial e EAD, evoluindo a cada etapa e permitindo ao futuro engenheiro o avanço no aprendizado e a correlação que existe entre as diversas áreas de uma organização com foco no Lean Manufactoring, objetivando ganhos de produtividade, otimização de custos e diminuição do lead time, entre outras.

A distribuição dentro de cada ciclo ficou assim definida:

a) Ciclo introdutório - Engenharia de Produção;

b) Ciclo 1 - Mapeamento de Processos, Manufatura Enxuta, Arranjo Físico de Fábrica e Gestão de Custos Industriais;

c) Ciclo 2 - Logística Empresarial, Cadeia de Suprimentos, Planejamento e Programação de Produção e Tempos e Métodos.

\subsection{ANÁLISE DAS EVIDÊNCIAS}

Como citado anteriormente, as primeiras ofertas de disciplinas de 2019 tiveram a implementação piloto do software em suas atividades práticas e isto foi de vital importância para a geração de evidências, uma nova exigência do MEC em suas visitas para a avaliação dos cursos. Os alunos realizaram a atividade proposta e após repetir a simulação localmente, apresentaram através da ferramenta repositória do Ambiente Virtual de Aprendizagem - AVA uma solução otimizada da simulação com a sugestão melhoria de produtividade para o processo.

Este fato também se evidenciou em meados de abril de 2019, quando o curso de Engenharia de Produção na modalidade EAD, passou pela etapa de reconhecimento com a presença dos avaliadores do MEC e um dos pontos destacados na referida avaliação foi exatamente a solução encontrada pela instituição para a materialização de atividades práticas a distância, que são consideradas de vital importância para a formação do engenheiro de produção nos instrumentos do MEC e atendem plenamente o estabelecido nas "DCNs".

Como continuidade da utilização do software nas atividades práticas das disciplinas dos ciclos 2 e 3 do curso, serão apresentados desafios de maior abrangência para potencializar o aprendizado e aproximar as atividades práticas da realidade prática das organizações. Como exemplo, na figura 3 pode ser visualizada uma simulação adequada ao segmento industrial que com as devidas adaptações poderão ser colocadas com o devido alinhamento com as diferentes ementas das disciplinas. 
FIGURA 3 - SIMULAÇÃO BÁSICA LINHA PRODUÇÃO

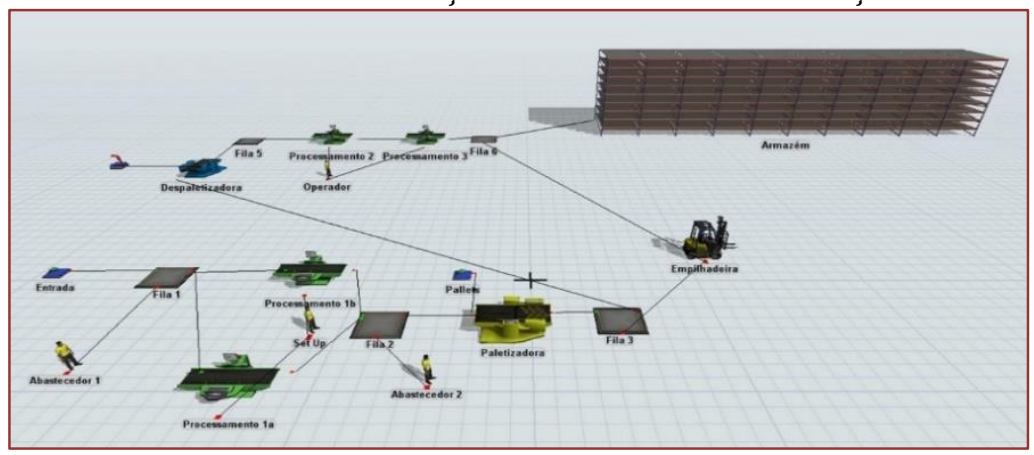

Fonte - Os Autores

O desafio a ser apresentado aos alunos poderia derivar da simulação de um turno completo de trabalho e a apresentação de uma solução mais produtiva e com menores custos como instrumento de avaliação da atividade prática.

\section{CONSIDERAÇÕES FINAIS}

Com base em toda exposição apresentada, pode-se concluir a importância desta grande melhoria implementada no portfólio prático da instituição, ampliando a capacidade prática do processo de formação antes restrita aos laboratórios físicos para a modalidade presencial e alguns virtuais como os disponibilizados para as disciplinas de física e química, além do kit pedagógico oferecido aos alunos do EAD.

O grande desafio que se apresenta a toda a equipe docente da instituição é tirar o maior proveito possível de toda a potencialidade apresentada pela solução oferecida pelo software, bem como o desenvolvimento de massa crítica para participar de congressos e eventos do ambiente acadêmico e de pesquisa com abrangência mundial. A própria FlexSim do Brasil tem recebido grandes contribuições de instituições e empresas que já vem utilizando a solução a mais tempo.

0 resultado das premissas descritas no presente artigo foi consolidado com a atribuição da nota máxima “5” para o curso de Engenharia de Produção EAD, repetindo a nota que a instituição já obtivera anteriormente na avaliação da modalidade presencial.

\section{REFERÊNCIAS}

[1] Moran J.M., Masetto M.T., Behrens M.A. Novas tecnologias e mediação pedagógica. Campinas - SP: Ed. Papirus, 2004

[2] Kenski V.M. Educação e tecnologias o novo ritmo da informação. Campinas - SP: Ed. Papirus, 2016

[3] Seila, A.F. Introduction to simulation. Anais da Conferência de Inverno de Simulação de 1995

[4] Flexsim Brasil. Manual de simulação I com flexsim. Campinas - SP: Ed. Própria, 2018

[5] Heredia, C. Saúde, saber e virtude. Disponível em http://saudesabervirtude.blogspot.com/2010/12/geracaof-geracao-facebook.html. Acesso em 28/04/2019 


\section{Capítulo 14}

O Ensino do Building Information Model (BIM) em uma instituição de ensino: Um estudo de caso

\section{Davi Teixeira Pinheiro}

\section{Rogério Severiano Dutra}

Resumo: O presente estudo com enfoque no ensino do Building Information Model (BIM) teve como objetivo geral investigar como está a disseminação e o interesse sobre o Building Information Model (BIM) entre os alunos do curso de graduação em engenharia civil de uma instituição de ensino superior. 0 delineamento metodológico do estudo de caso analisou gráficos de frequência construídos a partir das 92 respostas obtidas, estruturadas em formulário com sete questões objetivas e uma subjetiva. Como principal achado, confirma-se o pressuposto levantado de que os discentes consideram o BIM como ferramenta diferenciadora na indústria da construção civil a ser adotada no ensino superior.

Palavras-chave: Ensino superior. Construção civil. Building Information Model. 


\section{INTRODUÇÃO}

O Building Information Modeling (BIM) possibilita a visualização e desenvolvimento de projetos, assim como de organização da construção civil, propiciando a verificação de interdisciplinaridades e comunicação abrangente entre profissionais.

Pretti (2013) apresenta o BIM como sistema com a funcionalidade que designa modelos de edificações, contendo informações de materiais utilizados, processos adotados e documentação. Nas palavras de Eastman et al. (2011) é "uma tecnologia de modelagem e um conjunto associado de processos para produzir, comunicar e analisar modelos de construção".

Entretanto, as empresas do ramo podem oferecer resistência para a implantação desse sistema no mercado optando por utilizar métodos convencionais de elaboração e execução de projetos, devido à carência de docentes com habilitação para a formação do profissional. Tal afirmação é constatada no trabalho de Becerik-Gerber, Gerber e Ku (2011) que evidenciou que, majoritariamente, instituições não implantaram o BIM no ensino, devido à escassez de profissionais com habilidade e competência para lecionar.

Já a pesquisa de Panuwatwanich et al. (2013) atribui como adversidade para adoção do BIM aos currículos escolares: (i) tempo e recursos restrito; (ii) rigidez na matriz de ensino pré-existentes; e (iii) escassez de equipamentos e materiais necessários a capacitação. Além disso, Kymmel (2008) acrescenta que existem dificuldades de aprendizagem e operacionalização do software BIM, além da interpretação dos dados gerados.

Apesar dessa dificuldade, Fridrich e Kubečka (2014) preveem que as construções de maiores complexidades serão inviabilizadas sem o gerenciamento do BIM. Em consequência disso, Pikas, Sacks e Hazzan, (2013) prognosticam que haverá aumento na demanda por profissionais dominem o uso do BIM.

Assim, autores reconhecem a necessidade de incluir nos currículos educacionais do ensino superior, disciplinas que adotem o BIM para capacitar profissionais na área educacional e da indústria da construção civil (FRIDRICH; KUBECKA, 2014; ABBAS; DIN; FAROOQUI, 2016). A inserção do BIM demanda precipuamente a coordenação de docentes para reformulação de currículos acadêmicos e previsão de locais adequados ao ensino (BERWALD, 2008).

Desse modo, a evolução e modernidade de métodos e técnicas impõem novas responsabilidades ao ensino promovido pelas universidades, com o objetivo de viabilizar a formação de profissionais atualizados com as necessidades do mercado de trabalho relacionadas às diversas ferramentas (ABBAS et al. 2016).

Destarte, evidenciados a importância do ensino BIM nas instituições de ensino superior, este trabalho limita-se a levantar o interesse e contato dos alunos dos cursos técnicos, tecnológicos e bacharelados sobre Building Information Model (BIM) em uma Instituição de ensino básico, técnico e tecnológico do Estado do Ceará. Para isso, a pesquisa se desenvolve sobre a seguinte questão: como se encontra a disseminação do Building Information Model (BIM) entre os alunos do curso de graduação em engenharia civil de uma instituição de ensino superior? Para responder o questionamento esse estudo propõe como objetivo geral investigar como está a disseminação e o interesse sobre o Building Information Model (BIM) entre os alunos do curso de graduação em engenharia civil de uma instituição de ensino superior. Para alcançar o objetivo geral, são elaborados os seguintes objetivos específicos: (i) verificar o contato dos alunos do curso de graduação com o BIM; (ii) identificar o interesse dos alunos por uma disciplina sobre BIM; e (iii) mostrar a importância na visão dos alunos de uma disciplina sobre BIM no curso de engenharia civil.

\section{BUILDING INFORMATION MODEL (BIM)}

A atuação do profissional da construção civil, em projetos, contribui, dentre outros fatores, na otimização da eficiência da produtividade de qualidade e sustentável, além de propiciar a colaboração e diálogo com os stakeholders (NOUR, 2007; PRETTI, 2013).

O Building Information Model (BIM), presente nos processos do ciclo de vida do projeto, apresenta-se como ferramenta que tem a finalidade de simplificar e tornar mais eficiente à construção e operação de edifícios (AOUAD; ARAYICI, 2010; COATES et al., 2010), além de comportar, coletar, compartilhar e gerenciar informações de todas as etapas de um projeto (EASTMAN et al. , 2011). Um modelo BIM também pode ser compreendido como "uma representação digital de uma edificação, combinando informações tridimensionais e não-geométricas" (BIOTTO; FORMOSO; ISATTO, 2015). Isto é, contempla partes de um 
projeto como, geometria, dimensões, propriedades e quantidades, permitindo a criação e o armazenamento de informações geradas no ciclo de vida de um empreendimento (CHEN; LUO, 2014).

Além disso, o BIM é considerado um mecanismo que permite a comunicação abrangente e em tempo real de informações entre dos agentes envolvidos, possibilitando a percepção célere de problemas relativos à execução no projeto (PEDRINI, 2012).

Desse modo, dada à abrangência de requisitos do BIM, para sua implementação a empresa deve dominar as aplicações do software, remodelar o fluxo de trabalho, treinar pessoal, delegar responsabilidades e adotar novas modelagens de construção (BERNSTEIN; PITTMAN, 2004; EASTMAN et al., 2011), assim como, demandar por profissionais da construção com habilidades e conhecimentos BIM (PIKAS; SACKS; HAZZAN, 2013; BEZERRA et al., 2019).

Apesar dos possíveis benefícios, a inclusão do BIM com currículo de formação superior encontra barreiras a serem enfrentadas (BECERIK-GERBER; GERBER; KU, 2011; PANUWATWANICH et al., 2013), além da resistência do setor em preterir métodos convencionais (BEZERRA et al., 2019), apesar de autores acenarem que em breve, construções de elevada magnitude sejam inviabilizadas sem a utilização do BIM (FRIDRICH; KUBECKA, 2014).

Assim, é pertinente que as universidades promovam a educação técnica e o uso das tecnologias da informação em seus currículos (ABBAS et al., 2016). Contudo, as instituições de ensino superior vêm se deparando com dificuldades em contratar profissionais para capacitar de modo compreensivo a ferramenta BIM (LINO; AZENHA; LOURENÇO, 2012; GODOY; CARDOSO; BORGES, 2013; FRIDRICH; KUBECKA, 2014). Tal fato também foi constatado por Becerik-Gerber, Gerber e Ku (2011) que relataram que a maioria instituições de ensino não incluiu o BIM no currículo por falta de profissionais habilitados. Devido à carência de disciplinas obrigatórias, em alguns casos, o contato dos estudantes com tecnologia BIM tem sido suprido através de matérias eletivas ou workshops (BARISON; SANTOS, 2010; DEAMER; BERNSTEIN, 2011).

Pikas, Sacks e Hazzan, (2013) defendem que o ensino do BIM de modo contínuo e contato direto com a tecnologia, aperfeiçoam da capacidade dos estudantes de desenvolver trabalhos em conjunto. Aos estudantes interessam, dentre outros fatores, a criação dos projetos e a integração dos processos (FRIDRICH; KUBECKA, 2014). Outro fator da implementação do BIM nas instituições de ensino, é a possibilidade de realização de pesquisas e diferencial para o ingresso no mercado de trabalho (GHOSH; PARRISH; CHASEY, 2013).

Diante da necessidade de adequação do profissional da construção civil as modernas ferramentas de apoio ao planejamento e execução, à pesquisa apresenta o seguinte pressuposto: os discentes consideram o BIM como ferramenta diferenciadora na indústria da construção civil a ser adotada no ensino superior.

\section{PROCEDIMENTOS METODOLÓGICOS}

Segundo Prodanov e Freitas (2013), a construção do conhecimento é pautada na aplicação de técnicas e procedimentos, com o objetivo de comprova-lo perante a sociedade. Portanto, a presente pesquisa se desenvolve por meio da aplicação dos procedimentos como meio de atingir os objetivos propostos, dividindo-se em três etapas: (i) definição da pesquisa, (ii) estudo de campo e (iii) resultados.

Na etapa inicial, foi realizado o levantamento da literatura nos portais CAPES, Web of Science, Science Direct e Scopus. Neles, foram buscados trabalhos acadêmicos que tratavam sobre Building Information Model (BIM) e o ensino nos cursos de engenharias e afins. Após o levantamento, realizou-se a leitura dos trabalhos e a organização dos conceitos encontrados. Esse processo definiu o estado da arte e a formulação da questão de pesquisa e objetivos, por meio das lacunas e sugestões dessas pesquisas.

Em seguida, o estudo de campo determinou: (i) a elaboração do instrumento de pesquisa; (ii) os critérios para a realização da coleta de dados; e (iii) a caracterização do caso.

Assim, primeiramente, com base em trabalhos encontrados na literatura que tiveram aplicação em outra instituição de ensino superior semelhante, foi elaborado um formulário estruturado em três partes (caracterização do entrevistado, conhecimento do BIM e uma pergunta aberta com resposta a critério do entrevistado) com oito perguntas (sete objetivas e uma discursiva) como instrumento. No segundo momento, a realização da coleta de dados, utilizou-se a ferramenta Google Formulário e em seguida enviada aos entrevistados pelo sistema acadêmico da Instituição de Ensino pesquisada, ficando disponibilizada por 30 dias no sistema para que os alunos do departamento envolvido pudessem 
responder. Por fim, para a caracterização do caso em estudo foram considerados alunos do Departamento de Construção Civil de uma Instituição de Ensino localizada no Estado do Ceará. 0 departamento é composto de três cursos de ensino superior e dois cursos técnicos todos com foco na construção civil. Assim foram obtidas 92 respostas distribuídas entre os alunos do curso de graduação em engenharia civil de todos os semestres. As respostas utilizadas foram dos alunos do curso de engenharia civil.

Por ultimo, os resultados obtidos foram determinados por meio de análise de gráficos de frequência. Esses resultados apresentados foram confrontados com a literatura apresentada no início deste ensaio afim de responder os objetivos propostos.

\section{RESULTADOS}

A seção dividida em três partes destina-se a apresentar os resultados e discussões por meio de gráficos que evidenciam: o contato do aluno com o BIM, o interesse de uma disciplina sobre BIM e a importância de uma disciplina sobre BIM.

\subsection{CONTATO COM O BIM}

Os resultados apresentados no Gráfico 1 mostram que os alunos do curso de engenharia civil da instituição pesquisada já tiveram algum contato com o BIM. Sendo mais frequente em atividades fora das unidades curriculares da graduação, corroborando com os achados das pesquisas de Barison e Santos, (2010) e Deamer e Bernstein (2011).

Também é perceptível o contato durante a graduação nos semestres intermediários iniciais como o segundo, terceiro, quarto e quinto semestre. E em seguida, na segunda metade do curso em diante como o sétimo, oitavo e o nono. Entretanto, destaca-se a ausência no primeiro, sexto e principalmente no último semestre.

Contatos com o BIM dos alunos de graduação em engenharia civil

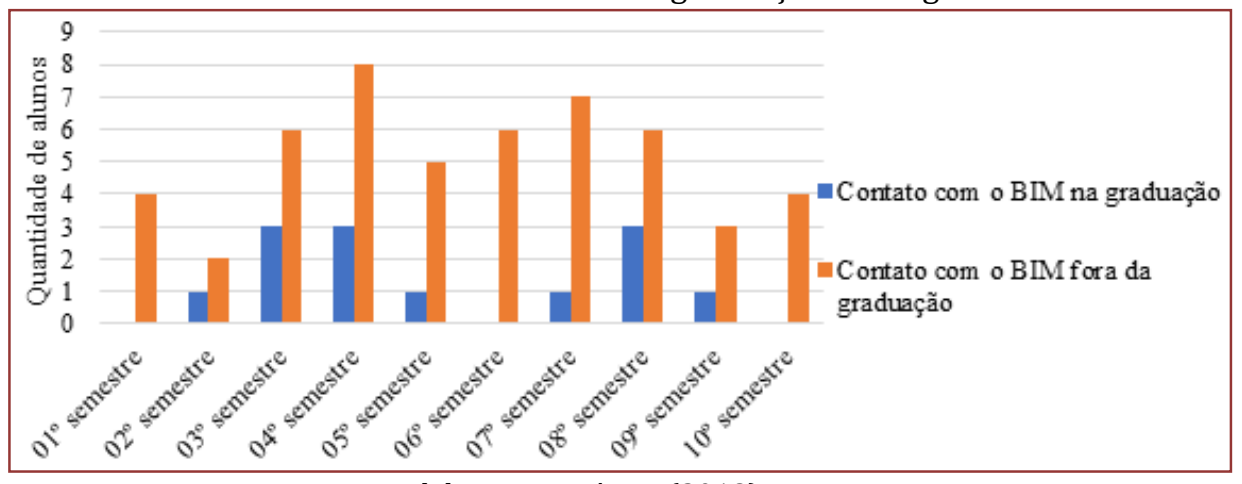

Fonte: elaboração própria (2018).

Por outro lado, os resultados mostram que os alunos do primeiro semestre já tiveram um contato prévio independente do curso. Mas não é possível admitir se o contato ocorrerá antes do ingresso no curso ou durante a realização do primeiro semestre.

Também foi identificado o contato com o BIM em todos os outros demais semestre, incluindo aqueles em que não foram identificados durante a graduação. Sendo assim, é possível supor que mesmo não tendo contato com o BIM nas atividades da graduação, os alunos do curso de engenharia civil têm buscado conhecer um pouco mais sobre a tecnologia em outros ambientes. Assim, os dados apresentam indícios de que o estudante entende que a incorporação dos conhecimentos do BIM nas unidades curriculares do curso de ocorrer de modo constante, em consonância com os resultados de Pikas, Sacks e Hazzan, (2013). 


\subsection{INTERESSE EM UMA DISCIPLINA SOBRE BIM}

O interesse dos alunos da graduação em Engenharia Civil no BIM ficou bem evidente no levantamento apresentado no Gráfico 2. Independente do semestre em que o aluno se encontra, o interesse pela disciplina em BIM é muito evidente.

Gráfico 2 - Interesse dos alunos da graduação em engenharia civil em cursos uma disciplina sobre BIM

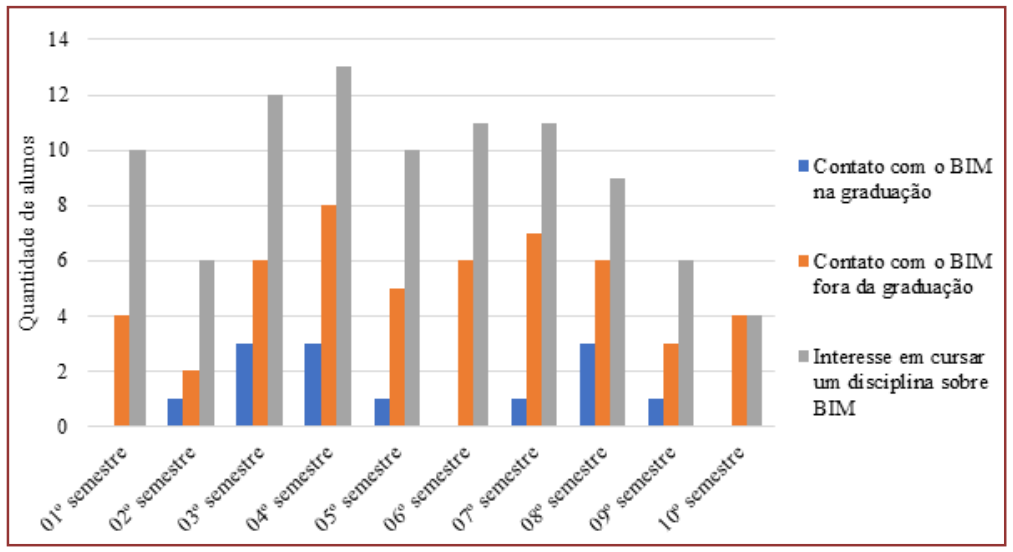

Fonte: elaboração própria (2018)

O interesse pela a presença do BIM na graduação é unanime quanto a todos os entrevistados, que pode indicar que os estudantes identificam a ferramenta como possível diferencial para ingresso no mercado de trabalho, apoiando os resultados encontrados nas pesquisas de Ghosh, Parrish e Chasey (2013) e Fridrich e Kubečka (2014). Observa-se também que o interesse é bem maior que os contatos já realizados pelos alunos dentro e fora do curso de graduação.

Portanto, a presença do BIM no curso e nas unidades curriculares é necessária para atender a demanda dos alunos. Porém, faz necessário identificar a demanda do mercado de trabalho quanto o foco a ser dado na aplicação do BIM.

\subsection{IMPORTÂNCIA DE UMA DISCIPLINA SOBRE BIM}

Após identificar a demanda de uma disciplina com foco em BIM, foi possível medir a importância dessa na graduação em engenharia civil na visão dos entrevistados conforme o Gráfico 3.

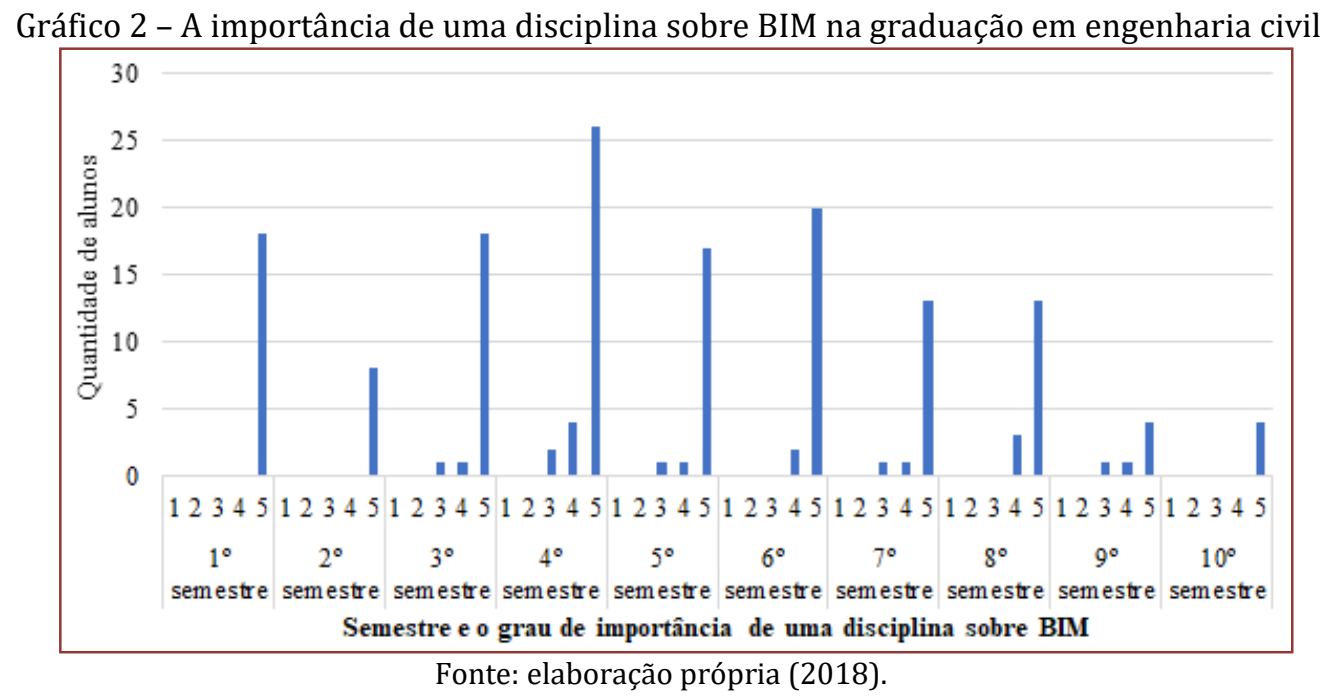

Em uma escala de 1 a 5, o resultado encontrado mostra que a grande maioria dos alunos dão a importação máxima a uma disciplina sobre BIM no curso de graduação em engenharia civil. Os demais respondentes, 
um total de 19, indicaram grau entre três e quatro para a importância, evidenciando que os estudantes demandam pela inclusão de uma disciplina sobre BIM no curso de graduação.

Com base nos resultados evidenciados nas três seções de resultados, confirma-se o pressuposto da pesquisa de que os discentes consideram o BIM como ferramenta diferenciadora na indústria da construção civil a ser adotada no ensino superior.

\section{CONSIDERAÇÕES FINAIS}

Em atendimento ao primeiro objetivo específico os resultados referentes ao contato dos alunos de graduação com o BIM, foi possível detectar que o contado dos alunos com a tecnologia BIM tem sido primordialmente fora do ambiente acadêmico em relação à oferta no curso de graduação. Apesar dessa constatação, a análise proposta no segundo objetivo específico, verifica-se que os alunos de todos os semestres apresentam interesse em cursar uma unidade curricular sobre BIM durante o curso de graduação em engenharia civil. Por fim, o terceiro objetivo específico, apontou que os alunos consideram elevada a importância para a existência de uma unidade curricular sobre BIM na graduação.

Tais resultados podem sugerir que os estudantes de Engenharia Civil tem considerado o conhecimento sobre o BIM como fator diferenciador para a realização das atividades profissionais, sendo notória a busca pela capacitação por meio de instituição de ensino superior ou em cursos.

Dentro das limitações da pesquisa e considerando os resultados obtidos, emergem algumas lacunas que podem ser aprofundadas futuramente por outros pesquisadores. A primeira está relacionada com a visão e dificuldade dos cursos de engenharia de instituições de ensino superior na oferta do BIM. Em seguida, torna-se relevante um levantamento sobre a importância do ensino do BIM nos cursos de graduação em engenharia civil na visão dos escritórios de arquitetura, engenharia, construtoras e afins. Por fim, pode-se verificar a visão dos alunos de outros cursos ligados a construção civil ao nível técnico, tecnológico e pósgraduação.

\section{REFERÊNCIAS}

[1] Abbas, A.; Din, Z. U.; Farooqui, R. Integration of BIM in Construction Management Education: An Overview of Pakistani Engineering Universities. Procedia Engineering, v. 145, p. 151-157, 2016.

[2] Aouad, G.; Arayici, Y. Requirements Engineering for Computer Integrated Environments in Construction, Wiley-Blackwell, Oxford, 2010.

[3] Barison, M.; Santos, E. Estratégias de Ensino BIM: uma visão geral das abordagens atuais. In: International Conference On Computing In Civil And Building Engineering (ICCCBE) 2010, Nottingham. Proceedings... Nottingham: ICCCBE, p. 577-584, 2010.

[4] Becerik-Gerber, B.; Gerber, D. J.; KU, K. The pace of technological innovation in architecture, engineering, and construction education: integrating recent trends into the curricula. Journal of Information Technology in Construction (ITcon), v. 16, p. 411-432, 2011. Disponível em: <http://www.itcon.org/2011/24>. Acesso em: 19 abr. 2019.

[5] Berwald, S. From CAD to BIM: The experience of architectural education with building information modeling. AEI, p. 1-5, 2008.

[6] Bernstein, P.G.; Pittman, J.H. Barriers to the Adoption of Building Information Modelling in the Building Industry, Autodesk Building Solutions, San Rafael, CA, 2004.

[7] Bezerra, P. H. P. et al. Proposal of execution plan Bim in the Junior civil engineering company of the Federal University of Paraná: an alternative for the introduction of Bim in the university formation. Brazilian Applied Science Review, v. 3, n. 2, p. 1136-1151, 2019.

[8] Biotto, C. N.; Formoso, C. T.; Isatto, E. L. Uso de modelagem 4D e Building Information Modeling na gestão de sistemas de produção em empreendimentos de construção. Ambiente Construído, Porto Alegre,v. 15, n. 2, p. 65-77, abr./jun. 2015.

[9] Chen, L. J.; LUO, H. A BIM-based construction quality management model and its applications. Automation in construction, v. 46, p. 64-73, 2014.

[10] Coates, P., Arayici, Y., Koskela, L., Kagioglou, M., Usher, C. O'reilly, K. “The key performance indicators of the BIM implementation process", Proceedings of the ICCBE Conference, June 30, Nottingham, 2010.

[11] Deamer, P.; Bernstein, P. G. (Ed.). BIM in Academia. Yale School of Architecture, 2011. 
[12] Eastman, C.; Teicholz, P.; Sacks, R.; Liston, K. BIM Handbook: a guide to building information modeling for owners, managers, designers, engineers, and contractors. 2. ed. New Jersey: John Wiley \& Sons, 2011.

[13] Fridrich, J.; Kubečka, K. BIM - The Process of Modern Civil Engineering in Higher Education. Procedia - Social and Behavioral Sciences, v. 141, p.763-767, 2014.

[14] Ghosh, A.; Parrish, K.; Chasey, A. D. From BIM to collaboration: A proposed integrated construction curriculum. In: 120th ASEE Annual Conference and Exposition, June 23-26, 2013, Atlanta. Proceedings...Atlanta: ASEE, 2013.

[15] Godoy, V.; Cardoso, C.; Borges, M. BIM: desafios para um conceito em construção no ensino de arquitetura e engenharia. In: Congresso Brasileiro de Educação Em Engenharia, 41., Gramado, 2013. Anais... Gramado: Cobenge, 2013.

[16] Lino, J. C.; Azenha, M.; Lourenço, P. Integração da Metodologia BIM na Engenharia de Estruturas. In: Encontro Nacional Betão Estrutural, Porto, 2012. Anais... Porto: FEUP, 2012.

[17] Nour, M. Manipulating IFC Sub-models in Collaborative Teamwork Environments, ITC Digital Library, available at: http://itc.scix.net. 2007.

[18] Panuwatwanich, K., Wong, M. L., Doh, J. H., Stewart, R. A., Mccarthy, T. J. Integrating building information modelling (BIM) into Engineering education: an exploratory study of industry perceptions using social network data. 2013.

[19] Pedrini, M. K. Engenharia Simultânea: planejamento e controle integrado do processo de produção/projeto na construção civil. 2012. 223f. Dissertação (Mestrado em Engenharia Civil) - Centro Tecnológico, Universidade Federal do Espírito Santo, Vitória, 2012.

[20] Pikas, E.; Sacks, R.; Hazzan, O. Building information modeling education for construction engineering and management. II: Procedures and implementation case study. Journal of Construction Engineering and Management, v. 139, n. 11, p. 05013002, 2013.

[21] Pretti, S. M. Engenharia Simultânea em construtoras incorporadoras: uma análise de maturidade. 2013. $246 f$. Dissertação (Mestrado em Engenharia Civil) - Centro Tecnológico, Universidade Federal do Espírito Santo, Vitória, 2013.

[22] Prodanov, C. C.; Freitas, E. C. Metodologia do trabalho científico: métodos e técnicas da pesquisa e do trabalho acadêmico. 2. ed. - Novo Hamburgo: Feevale, 2013. ISBN 978-85-7717-158-3 


\section{Capítulo 15}

\section{Alunos ingressantes e risco de evasão: Uma aplicação do modelo de tinto no curso de ciências contábeis da UFRN}

\section{Daniele da Rocha Carvalho \\ Franklyn Kennedy da Silva \\ Ridalvo Medeiros Alves de Oliveira}

Resumo: A evasão nas instituições de ensino superior é um problema que impacta a vida do estudante, a universidade e, por conseguinte, a sociedade. Partindo dessa premissa, este trabalho busca identificar as características dos alunos que se encontram em risco de evasão, seguindo a teorização do modelo de Tinto (1997). Mais especificamente, a pesquisa tem por objetivos traçar um perfil dos alunos que ingressaram nos períodos de 2018.1 e 2018.2 (turnos matutino e noturno), para identificar as variáveis que possam influenciar na trajetória do aluno a partir da teoria de Tinto (1997) e indicar um desenho da trajetória de insucesso. A coleta de dados se deu por meio de questionário com 49 questões semiabertas. Esse questionário foi respondido por 127 alunos, dos quais apenas 91 foram considerados, por terem sido respondidos integralmente. Utilizou-se o software Excel para a tabulação e a geração dos resultados. Dos resultados obtidos, as principais semelhanças no perfil dos estudantes na trajetória de insucesso são que eles possuem até 25 anos, são solteiros, não tiveram filhos, estudaram parcialmente em escola pública, não tiveram ciências contábeis como primeira opção de curso e já pensaram em desistir do curso.

Palavras-chave: Evasão, Perfil do aluno, Trajetória de insucesso, Modelo de Tinto. 


\section{INTRODUÇÃO}

A evasão é um assunto estudado em todo mundo. Ao longo dos anos, diversos autores se debruçam com o intuito de buscar explicações mais refinadas, desenvolver e/ou aprimorar modelos do perfil e da trajetória dos estudantes evadidos ou em risco de evasão. Assim, tenta-se constantemente encontrar soluções mais práticas e decisivas para conter essa dificuldade no ambiente escolar.

É importante considerar que a desistência do aluno é muito mais ampla do que apenas deixar de frequentar o curso. Cunha et al $(2000$, p. 279) afirmam que "o prejuízo com a saída do aluno do curso é certo: perde o aluno ao não se diplomar, perde o professor que não se realiza como educador, a universidade, a família e a sociedade. Perde o país, que olha para o futuro e espera". Percebe-se, dessa forma, a abrangência dos impactos do ato do abandono.

Em questões monetárias, Silva et al (2007, p. 642) defendem que

a evasão estudantil no ensino superior é um problema internacional que afeta o resultado dos sistemas educacionais. As perdas de estudantes que iniciam, mas não terminam seus cursos são desperdícios sociais, acadêmicos e econômicos. No setor público, são recursos públicos investidos sem o devido retorno. No setor privado, é uma importante perda de receitas. Em ambos os casos, a evasão é uma fonte de ociosidade de professores, funcionários, equipamentos e espaço físico.

Nesse sentido, a relevância e o impacto desse tema em diversos setores da sociedade são elencados e sentidos. Cabe o estudo exaustivo nessa temática, porque as pessoas são dinâmicas, e não estáticas. A constante mudança requer o aprimoramento de modelos e a atualização de estudos para minimizar os riscos de evasão e maximizar trajetórias de sucessos.

Dada a relevância do tema, o presente trabalho busca identificar o perfil dos alunos no curso de ciências contábeis da Universidade Federal do Rio Grande do Norte (UFRN) com risco de evasão, que ingressaram em 2018.1 e 2018.2, por meio do modelo apresentado por Tinto (1997), intitulado "modelo de salas de aula, aprendizagem e permanência". A partir das ideias do teórico, foi desenvolvido um questionário acerca da trajetória do aluno no ensino superior, revelando os pontos convergentes ao modelo.

\section{METODOLOGIA}

Esta pesquisa pode ser caracterizada, de acordo com a tipologia proposta por Beuren (2009) como uma pesquisa descritiva quanto aos objetivos, como bibliográfica e de levantamento quanto aos procedimentos e, no que tange à abordagem do problema, é parte quantitativa e parte qualitativa.

0 universo da pesquisa era composto pelos estudantes do curso de graduação em Ciências Contábeis da Universidade Federal do Rio Grande do Norte, que ingressaram em 2018. Em 2018.1, no turno matutino ingressaram 51 alunos e, no noturno, 48. Dos que ingressaram em 2018.2, foram 65 no turno matutino e 60 no noturno.

Desse universo, 127 alunos que responderam ao questionário parcial ou integralmente. Dessa amostra, foram retirados 36 questionários e o critério de exclusão estabelecido teve por fundamento o fato de terem sido respondidos parcialmente, o que poderia gerar distorção nos resultados globais. Dessa forma, a análise dos dados foi realizada a partir de 91 questionários.

O questionário dividia-se em dois grupos: o primeiro buscava captar o perfil do respondente, enquanto o segundo grupo investigava sobre o curso, focando, principalmente, sobre a integração, os programas institucionais, a relação professor-aluno, uma autoavaliação sobre a atuação no curso e a sua relação com os pares.

No que concerne à análise dos dados, foi realizada uma análise descritiva, utilizando o software Microsoft Excel para filtrar dados, calcular percentuais e médias e gerar gráficos e tabelas. Posteriormente, foram interpretados os resultados a partir de um diálogo com a teoria. 


\section{DESENVOLVIMENTO}

Na década de 1970 Tinto desenvolveu uma teoria na qual categorizou o que antes era tido como abandono, passando a ter uma classificação mais detalhada: fracasso acadêmico, desistência voluntária, abandono, afastamento temporário e transferência. 0 modelo longitudinal explora aspectos e processos que levam os estudantes a decidirem por abandonar, ainda que temporariamente, a universidade.

Resultado de aprofundamento de seus estudos para o desenvolvimento de sua teoria, Tinto (1975, 1993, 1997) enfatizou a necessidade de conhecer o contexto pré-ingresso do estudante na universidade. Ele elege o contexto familiar (status socioeconômico, por exemplo), os atributos individuais (sexo e as habilidades acadêmicas, entre outras) e as experiências anteriores (sociais e acadêmicas, como formação e histórico escolar e desenvoltura nos relacionamentos sociais) como características para esse item. Seguindo, cabe identificar os compromissos com o objetivo do estudante, evidenciando as intenções e os compromissos com a instituição e com o objetivo. Esses compromissos são os externos, ou seja, motivadores da permanência do aluno na instituição.

Em concordância com os objetivos, as experiências institucionais são formadas pelos sistemas acadêmico e social. Essa aliança, ressaltada por Tinto (1993), é de grande valia, porque, nesse aspecto, busca-se a visão da integração acadêmica pelo próprio discente, a qual é refletida nas avaliações (desempenho acadêmico) e no desenvolvimento intelectual (atividades extracurriculares). Os ambientes acadêmico e social, segundo o autor, precisam estar em equilíbrio. Tinto (1993) elucida que, uma vez havendo excesso na integração social, poderá significar um déficit acadêmico, diferentemente se essa integração ocorrer com colegas sob uma eficiente orientação acadêmica, a qual proporcionará a formação de um grupo de apoio no alcance dos objetivos e incrementará a integração acadêmica.

Dessa maneira, nas próximas etapas do modelo, Tinto (1997), após o reconhecimento pessoal/normativo, considerou a importância da aprendizagem. Esse aspecto pode influenciar o discente a permanecer ou a abandonar o curso e a instituição, do que se depreende a relevância de haver integração social e acadêmica. Assim sendo, esse engajamento reforça os compromissos com os objetivos, no que tange às intenções e aos compromissos com a instituição e com o próprio objetivo de estar na graduação, resultando na permanência do estudante. A Figura 1 apresenta o resultado do modelo de Tinto (1997), desenvolvido após as revisões feitas ao longo de seus estudos após a publicação de sua primeira versão em 1975.

Figura 1 - Modelo de salas de aula, aprendizagem e permanência (TINTO, 1997)

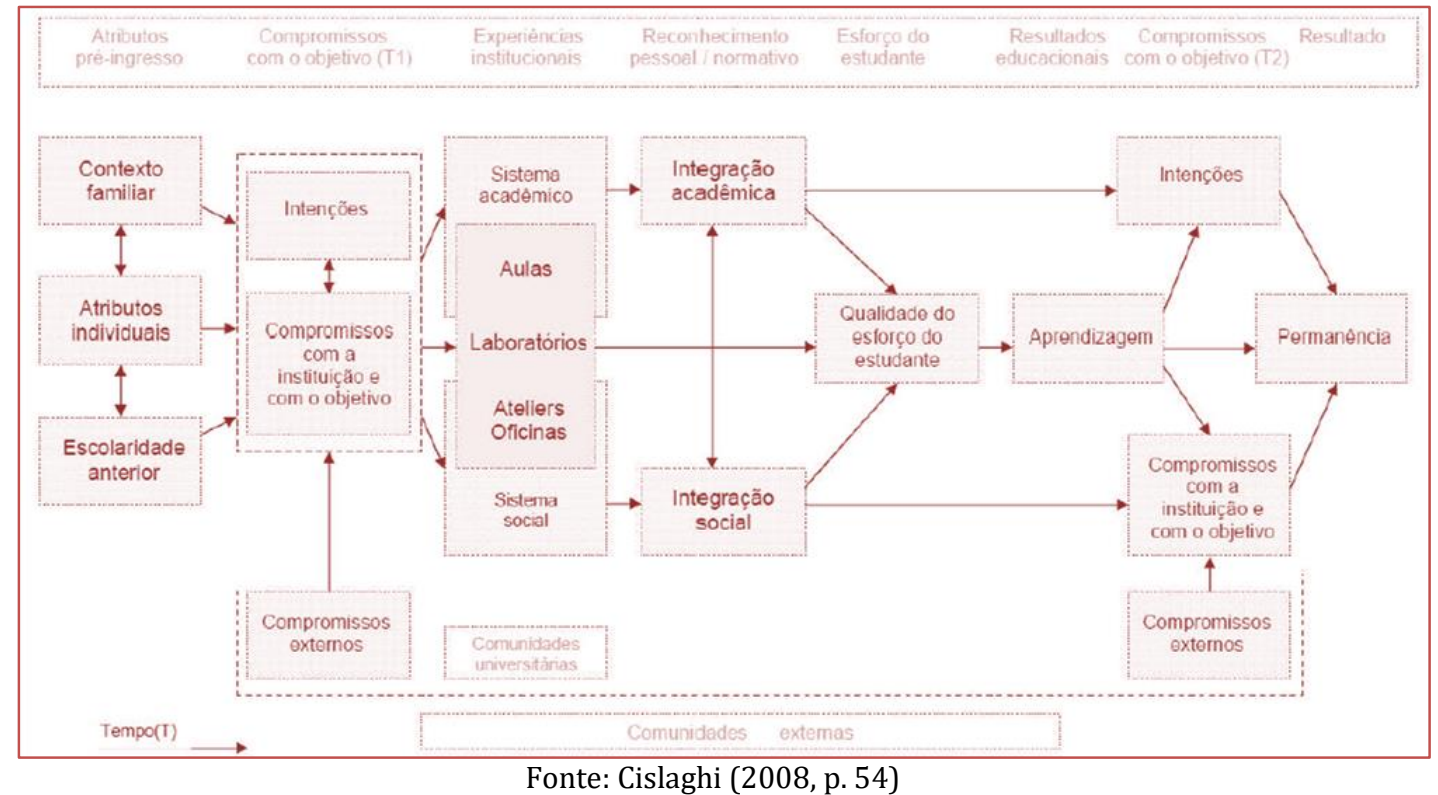




\section{RESULTADOS E DISCUSSÃO}

Os gráficos e tabelas a seguir apresentados indicam os perfis dos alunos que responderam integralmente os questionários, separados por turno.

Gráfico 1- Sexo e idade para o turno matutino

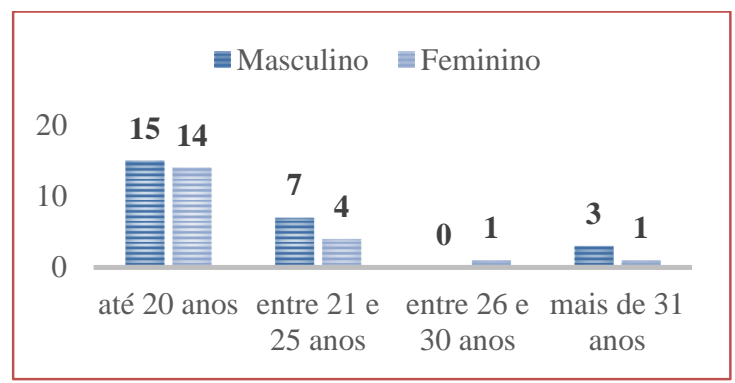

Gráfico 3 - Estado civil para o turno matutino

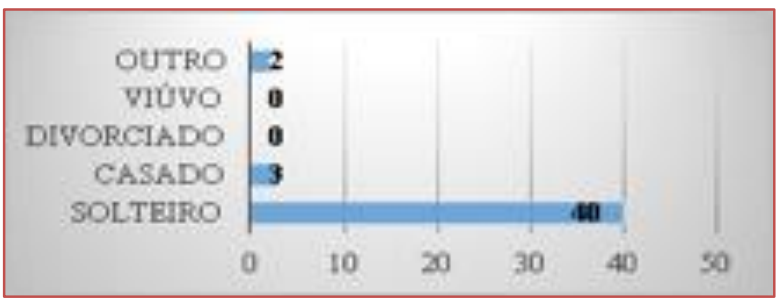

Gráfico 5 - Disciplinas com maior identificação para o turno matutino

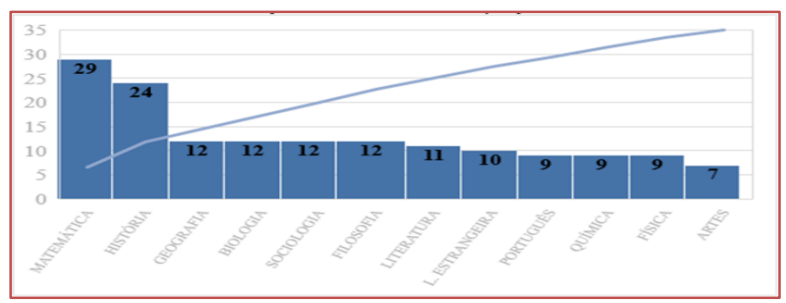

Gráfico 7 - Atributos individuais para o turno matutino

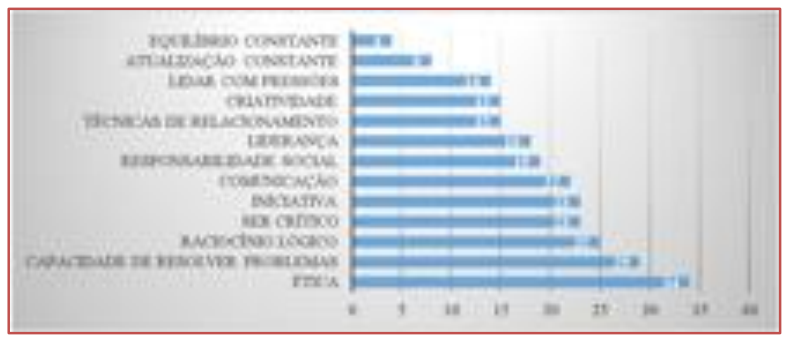

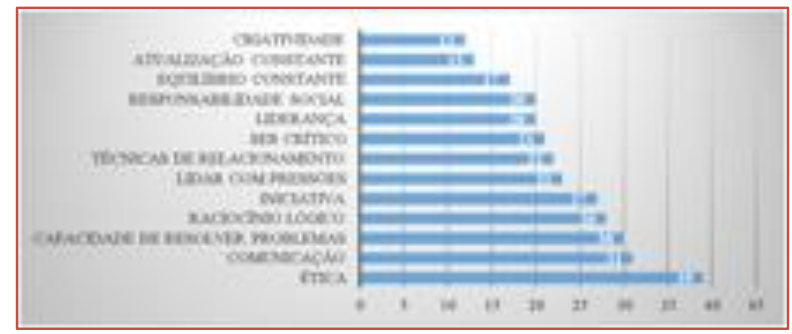

Gráfico 2 - Sexo e idade para o turno noturno

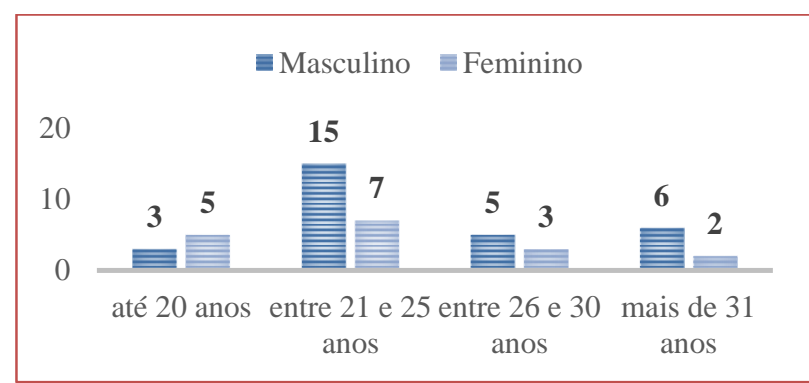

Gráfico 4 - Estado civil para o turno noturno

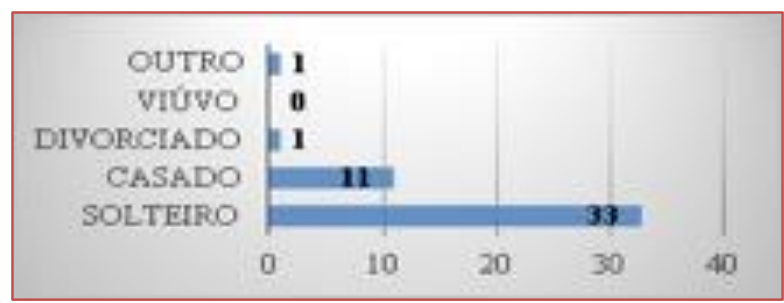

Gráfico 6 - Disciplinas com maior identificação para o turno noturno

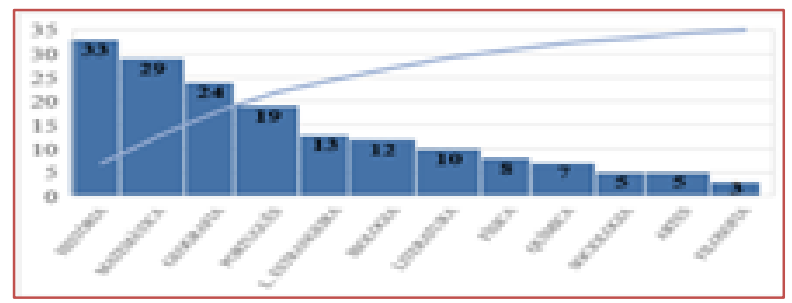

Gráfico 8 - Atributos individuais para o turno noturno

Fonte: Dados da pesquisa (2019) 
Tabela 1 - Relação entre renda familiar e tipo de escola

\begin{tabular}{|c|c|c|c|c|c|c|c|c|c|c|c|c|c|c|c|c|}
\hline \multirow{3}{*}{$\begin{array}{c}\text { Variáveis } \\
\text { Renda familiar } \\
\text { (salários mínimos) }\end{array}$} & \multicolumn{8}{|c|}{ Turno Matutino } & \multicolumn{8}{|c|}{ Turno Noturno } \\
\hline & \multicolumn{8}{|c|}{ TIPO DE ESCOLA } & \multicolumn{8}{|c|}{ TIPO DE ESCOLA } \\
\hline & $\mathrm{IEPu}$ & $\%$ & IEPr & $\%$ & $\mathrm{PEPu}$ & $\%$ & $\operatorname{PEPr}$ & $\%$ & $\mathrm{IEPu}$ & $\%$ & IEPr & $\%$ & $\begin{array}{c}\text { PEP } \\
\mathrm{u}\end{array}$ & $\%$ & $\begin{array}{l}\mathrm{PE} \\
\mathrm{Pr}\end{array}$ & $\%$ \\
\hline até 1 & 9 & $20 \%$ & 6 & $13 \%$ & 4 & $9 \%$ & 3 & $7 \%$ & 5 & $11 \%$ & 5 & $11 \%$ & 4 & $9 \%$ & 0 & $0 \%$ \\
\hline entre 1 e 4 & 5 & $11 \%$ & 3 & $7 \%$ & 3 & $7 \%$ & 0 & $0 \%$ & 15 & $33 \%$ & 4 & $9 \%$ & 3 & $7 \%$ & 2 & $4 \%$ \\
\hline entre 4 e 7 & 4 & $9 \%$ & 1 & $2 \%$ & 1 & $2 \%$ & 0 & $0 \%$ & 0 & $0 \%$ & 6 & $13 \%$ & 2 & $4 \%$ & 0 & $0 \%$ \\
\hline entre 7 e 10 & 0 & $0 \%$ & 2 & $4 \%$ & 0 & $0 \%$ & 0 & $0 \%$ & 0 & $0 \%$ & 0 & $0 \%$ & 0 & $0 \%$ & 0 & $0 \%$ \\
\hline acima de 10 & 0 & $0 \%$ & 4 & $9 \%$ & 0 & $0 \%$ & 0 & $0 \%$ & 0 & $0 \%$ & 0 & $0 \%$ & 0 & $0 \%$ & 0 & $0 \%$ \\
\hline
\end{tabular}

IEPu - Integralmente em Escola Pública; IEPr - Integralmente em Escola Privada, PEPu - Parcialmente em Escola Pública; PEPr - Parcialmente em Escola Privada

Fonte: Dados da pesquisa (2019)

Na sequência, estão os gráficos que identificam as variáveis que podem influenciar na trajetória do aluno.

Gráfico 9 - Escolha do curso para o turno matutino

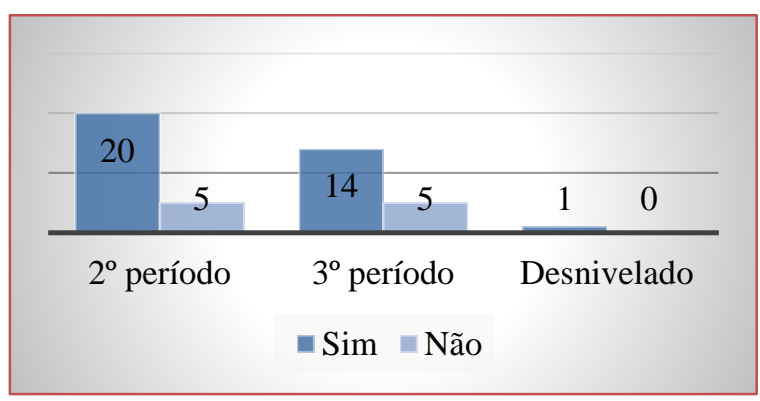

Gráfico 11 - Motivo da escolha do curso para turno

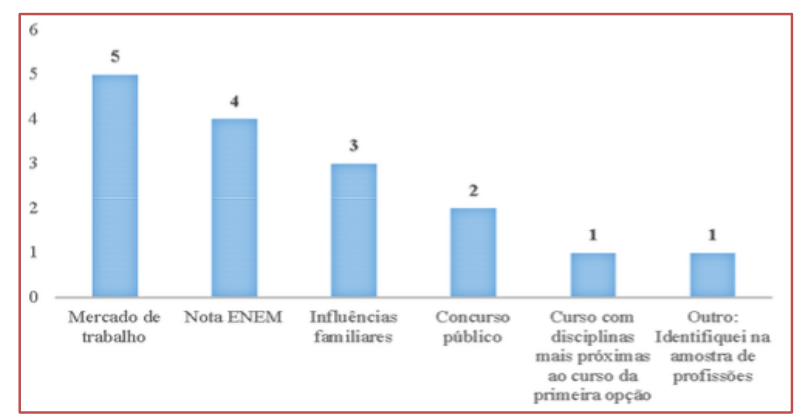

matutino
Gráfico 10 - Escolha do curso para o turno noturno

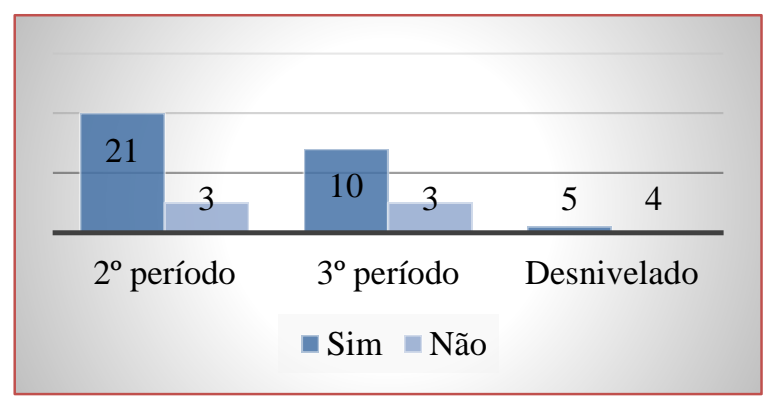

Gráfico 12 - Motivo da escolha do curso para turno

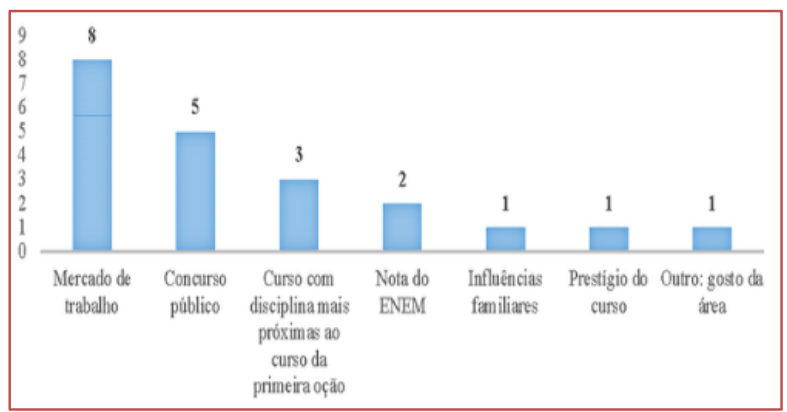

noturno 
Gráfico 13 - Programa institucional para o turno

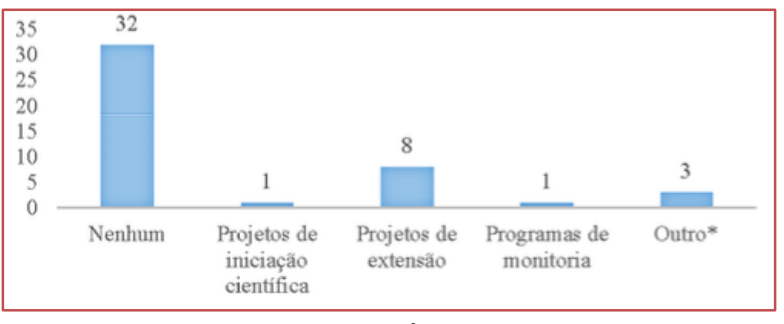

matutino

Gráfico 15 - Identificação com as disciplinas para o

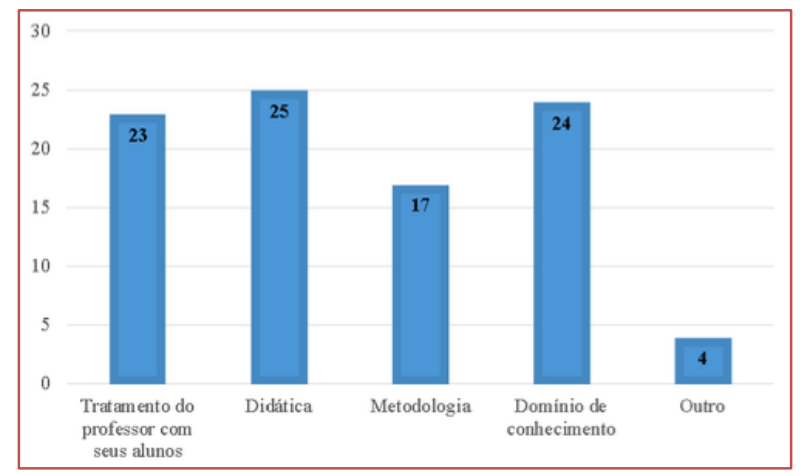

turno matutino

Gráfico 17 - Motivação para concluir o curso para o

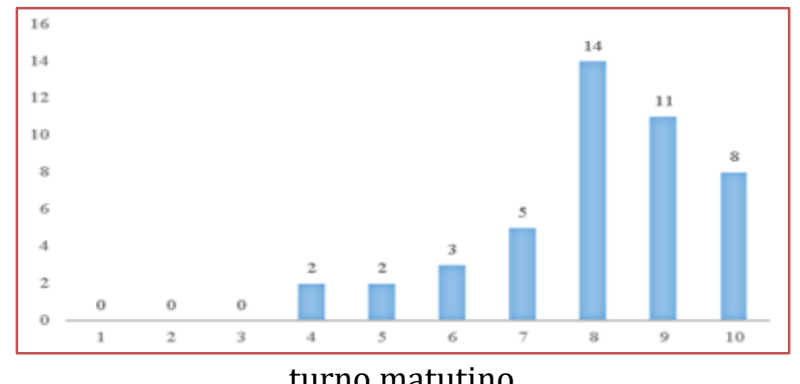

turno matutino
Gráfico 14 - Programa institucional para o turno

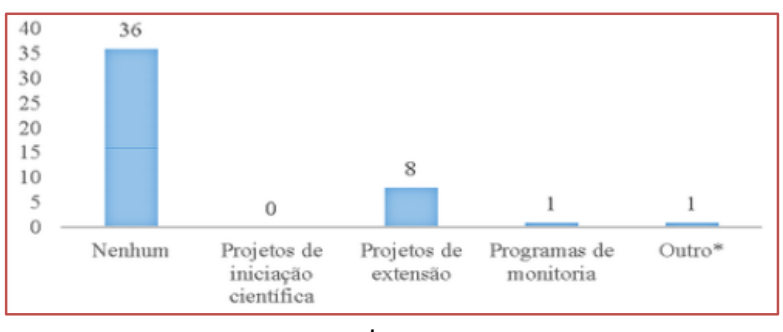

noturno

Gráfico 16 - Identificação com as disciplinas para o

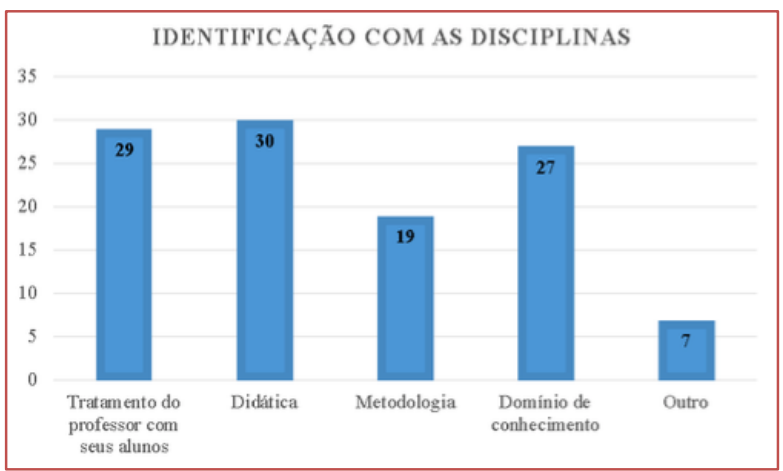

turno noturno

Gráfico 18 - Motivação para concluir o curso para o

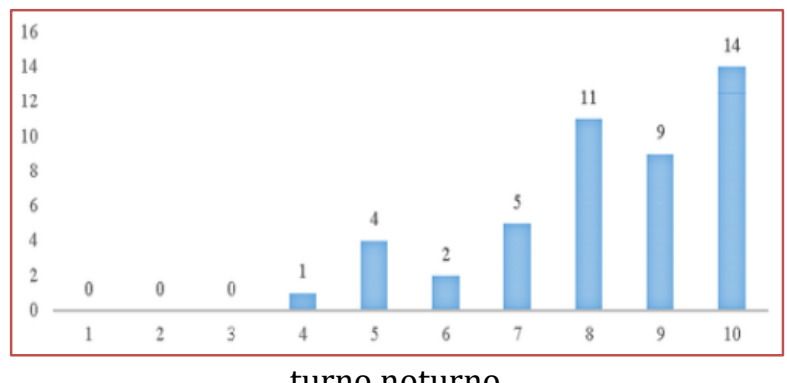

turno noturno

Fonte: Dados da pesquisa (2019)

Fechando a apresentação de resultados, os Quadros 1 e 2 apresentam os fatores que influenciam negativamente a adaptação dos alunos à vida universitária, segundo respostas dos alunos dos turnos matutino e vespertino, respectivamente. 
Quadro 1 - Fatores que influenciam de forma negativa a adaptação à vida universitária para o turno matutino

\begin{tabular}{|l|c|}
\hline \multicolumn{1}{|c|}{ FATORES } & FREQUÊNCIA \\
\hline Indisponibilidade de tempo & 16 \\
\hline Falta de motivação para os estudos & 16 \\
\hline Problemas financeiros & 15 \\
\hline Ausência de hábitos de estudo & 13 \\
\hline Falta de tempo para se dedicar aos estudos por motivos de traballho & 13 \\
\hline Falta de competência para estudar com eficiência & 9 \\
\hline Problemas familiares & 8 \\
\hline Baixa qualidade da escola de ensino básico & 8 \\
\hline Inadequação de metodologia usadas nas disciplinas & 7 \\
\hline Falta de incentivos & 7 \\
\hline Dificuldades de aprendizagem dos conteúdos das disciplinas & 5 \\
\hline Falta de apoio da instituição e/ou do curso & 4 \\
\hline A não identificação com o curso & 4 \\
\hline Desconhecimento da proposta pedagógica do curso & 3 \\
\hline Baixo rendimento nas disciplinas e/ou reprovação & 3 \\
\hline Falta de perspectiva no mercado de trabalho & 2 \\
\hline Dificuldade de adaptação & 2 \\
\hline Problemas de relacionamento com os professores & 2 \\
\hline Impossibilidade de frequentar as aulas & 1 \\
\hline Alta exigência nas avaliações & 1 \\
\hline
\end{tabular}

Quadro 2 - Fatores que influenciam de forma negativa a adaptação à vida universitária para o turno NOTURNO

\begin{tabular}{|l|c|}
\hline \multicolumn{1}{|c|}{ FATORES } & FREQUÊNCIA \\
\hline Indisponibilidade de tempo & 29 \\
\hline Falta de tempo para se dedicar aos estudos por motivos de trabalho & 23 \\
\hline Ausência de hábitos de estudo & 18 \\
\hline Dificuldades de aprendizagem dos conteúdos das disciplinas & 12 \\
\hline Falta de competência para estudar com eficiência & 10 \\
\hline Falta de motivação para os estudos & 10 \\
\hline Problemas financeiros & 9 \\
\hline Problemas familiares & 7 \\
\hline Problemas de relacionamento com os professores & 5 \\
\hline Baixa qualidade da escola de ensino básico & 5 \\
\hline Falta de incentivos & 5 \\
\hline Falta de apoio da instituição e/ou do curso & 4 \\
\hline Impossibilidade de frequentar as aulas & 4 \\
\hline Alta exigência nas avaliações & 4 \\
\hline Baixo rendimento nas disciplinas e/ou reprovação & 4 \\
\hline Dificuldade de adaptação & 3 \\
\hline Inadequação de metodologia usadas nas disciplinas & 3 \\
\hline Falta de perspectiva no mercado de trabalho & 1 \\
\hline Desconhecimento da proposta pedagógica do curso & 1 \\
\hline A não identificação com o curso & 1 \\
\hline
\end{tabular}

Fonte: Dados da pesquisa (2019)

O foco maior na teorização de Tinto (1997), explicada anteriormente, está na integração acadêmica e social do estudante. Diante do exposto, o perfil que se desenha para uma trajetória de insucesso é daquele aluno que já pensou em desistir, não participa de programas institucionais da universidade, tem poucas horas de estudo fora da sala de aula, não percebe os esforços feitos pela academia, não participa de grupo de estudo e se diz insatisfeito ou desmotivado.

Desse modo, aplicando os filtros supracitados, foram encontrados prováveis discentes com suas trajetórias de insucesso. Para o matutino teve um total de dois graduandos, conforme apresentado no Quadro 3.

Quadro 3 - Perfil da trajetória de insucesso do turno matutino

\begin{tabular}{|l|l|l|}
\multicolumn{2}{|c|}{ QUESITOS } & \multicolumn{2}{c}{ RESPONDENTE 1 } & Feminino \\
\hline Gênero & Masculino & Até 20 anos \\
\hline Idade & Entre 21 e 25 anos & Solteiro \\
\hline Estado Civil & Solteiro & Nenhum \\
\hline Quantidade de filhos & Nenhum & Entre 1 e 4 salários mínimos \\
\hline Faixa de renda mensal & Entre 4 e 7 salários mínimos & Integralmente em escola pública \\
\hline Antes da graduação estudou & Parcialmente em escola pública & Ensino médio completo \\
\hline Grau de instrução da mãe & Pós-graduação incompleto & Ensino médio completo \\
\hline Grau de instrução do pai & Ensino médio completo & 3o período \\
\hline Período & 3 o período & Não, fisioterapia \\
\hline Primeira opção de curso & Não, era direito & Sim \\
\hline Já pensou em desistir do curso? & Sim & \\
\hline
\end{tabular}

Fonte: Dados da pesquisa (2019)

Como se pode observar no Quadro 3, os dois sexos estão presentes, mas as idades estão em faixas distintas, assim como a faixa salarial. Além disso, ambos são solteiros e não têm filhos. Quanto à instrução, há divergência quanto ao percurso escolar, o que ocorre também com a instrução das mães; os pais, no entanto, convergiram nesses resultados. Embora no mesmo período, os respondentes também admitiram 
já ter pensado em abandonar o curso, dado que coincide com o fato de ambos não terem tido ciências contábeis como primeira opção de curso.

Para o turno noturno, após a aplicação dos filtros, foram identificados 2 possíveis estudantes formando uma trajetória de insucesso, conforme mostrado no Quadro 4.

Quadro 4 - Perfil da trajetória de insucesso do turno noturno

\begin{tabular}{|l|l|l|}
\multicolumn{1}{|c|}{ QUESITOS } & \multicolumn{2}{c|}{ RESPONDENTE 1 } \\
\hline Gênero & Masculino & Masculino \\
\hline Idade & Entre 21 e 25 anos & Entre 21 e 25 anos \\
\hline Estado Civil & Solteiro & Solteiro \\
\hline Quantidade de filhos & Nenhum & Nenhum \\
\hline Faixa de renda mensal & Até 1 salário mínimo & Entre 1 e 4 salários mínimos \\
\hline Antes da graduação estudou & Parcialmente em escola pública & Parcialmente em escola pública \\
\hline Grau de instrução da mãe & Ensino superior completo & Pós-graduação completa \\
\hline Grau de instrução do pai & Ensino superior incompleto & Ensino fundamental incompleto \\
\hline Período & Estou desnivelado & Estou desnivelado \\
\hline Primeira opção de curso & Não, educação física & Não, publicidade e propaganda \\
\hline Já pensou em desistir do curso? & Sim & Sim \\
\hline & \multicolumn{1}{|c|}{ Fonte: Dados da pesquisa (2019) } & \\
\hline
\end{tabular}

Observa-se no Quadro 4 a presença de um perfil masculino de mesma faixa etária, solteiro e sem nenhum filho. 0 quesito econômico teve uma divergência. Já o escolar, inicialmente, mostrou-se parecido com a origem escolar, mas com diferenças no grau de instrução materna e paterna. Um dado considerável é o desnivelamento apresentado por ambos, o que diferencia bastante do período matutino. Entretanto, o perfil noturno aproxima-se do matutino quanto às ponderações de desistência de curso, algo que, possivelmente, deve estar atrelado ao fato de também não terem ciências contábeis como primeira opção.

Ainda que haja diferenças entre os perfis supracitados, eles não podem ser desconsiderados, porque há várias semelhanças nos resultados presentes nos Quadros 3 e 4, como ser prioritariamente masculino, ter entre 21 e 25 anos, ser solteiro, não ter filho, ter estudado, ainda que parcialmente, em escola pública, não ter ingressado na primeira opção de curso e ter cogitado interromper a graduação. Por isso, pode-se dizer que, a partir da amostra analisada, a qual leva em consideração os alunos de ciências contábeis ingressantes em 2018.1 e 2018.2, a combinação dessas características pode desenhar uma trajetória de insucesso.

\section{CONSIDERAÇõES FINAIS}

A pesquisa em tela buscou identificar, primordialmente, as características dos alunos que se encontram com risco de evasão. Com as respostas obtidas por meio do questionário, estabelecendo diálogos com os teóricos, sobretudo com Tinto (1997), traçou-se o perfil dos alunos que ingressaram nos períodos 2018.1 e 2018.2, e foram identificadas e analisadas as variáveis que influenciam na trajetória do aluno a partir da teoria do referido estudioso e, por fim, houve indicação da trajetória de insucesso.

A maior parte dos respondentes é do sexo masculino. No turno noturno, percebe-se uma maior concentração das idades a partir dos 21 anos. Também é nesse turno que apenas $22 \%$ dos pais ingressaram no ensino superior, menor variação de renda familiar e maior o número de estudantes oriundos de escolas públicas. Nesse sentido, se pode aludir a algumas comparações com trabalhos já publicados. Algumas delas dizem respeito a uma aproximação com as contribuições de Lopes (2014), que também concluiu problemas relacionados à primeira opção de curso, Alencar (2014), que discutiu em suas considerações finais acerca do ponto crítico da evasão que ocorre entre o segundo e quinto período (os alunos estudados nesta pesquisa estão dentro desse período), e Sousa et al (2016), que findaram seu trabalho apontando a predominância dos evadidos serem do sexo masculino. Outra pesquisa se distancia desse perfil, como a de Fritsch et al (2015), que concluíram seu trabalho sinalizando uma faixa etária superior a 30 anos para alunos que estão em risco de evasão, e, neste trabalho, foi de até 25 anos. 
Os participantes percebem, em grande maioria, os esforços empregados pela UFRN para que eles permaneçam no curso. Esse entendimento é sentido em relação ao auxílio extraclasse dado pelos professores quando são procurados, além de se sentirem apoiados pelos colegas. Entretanto, os programas institucionais não são adotados por grande parte dos discentes, como também a falta de tempo para se dedicar ao universo acadêmico e aos estudos são outros dois senões.

As limitações encontradas no trabalho foram o não preenchimento integral do questionário por parte de 36 estudantes, quando houve a aplicação. Além disso, devido ao tempo reduzido da pesquisa, não foi possível fazer um estudo longitudinal para acompanhar as nuances do grupo estudado. Recomenda-se que a mesma amostra seja questionada mais de um período, com o intuito de perceber as mudanças ou reafirmações do perfil, como também se o desenho do perfil de insucesso ocasionou, de fato, a evasão.

\section{REFERÊNCIAS}

[1] ALENCAR, Liliana de Melo Braz. A evasão discente no contexto da estruturação universitária: o caso dos cursos de administração e ciências contábeis da Universidade Federal do Espírito Santo. 2014. 205 f. Dissertação (Mestrado em Gestão Pública) - Universidade Federal do Espírito Santo, Vitória, 2014. Disponível em: http://repositorio.ufes.br/bitstream/10/1203/1/A\%20evasao\%20discente\%20no\%20contexto\%20da\%20reestrutu racao $\% 20$ universitaria $\% 20 \% 3 \mathrm{~A} \% 20 \mathrm{o} \% 20$ caso $\% 20 \mathrm{dos} \% 20$ cursos $\% 20 \mathrm{de} \% 20$ Administracao $\% 20 \mathrm{e} \% 20$ Ciencias $\% 20$ Contabeis\%20da\%20Universidade\%20Federal\%20do\%20Espirito\%20Santo.pdf. Acesso em: 12 maio 2019.

[2] BEUREN, Ilse Maria. Como elaborar trabalhos monográficos em contabilidade: Teoria e prática. 4. ed. São Paulo: Atlas, 2009.

[3] CISLAGHI, Renato. Um modelo de sistema de gestão do conhecimento em um framework para a promoção da permanência discente no ensino de graduação. 2008. 273 f. Tese (Doutorado em Engenharia e Gestão do Conhecimento) - Universidade Federal de Santa Cataria, Florianópolis, 2008.

[4] CUNHA, Jacqueline Veneroso Alves da et al. Quem está ficando para trás? Uma década de evasão nos cursos brasileiros de graduação em administração de empresas e ciências contábeis. Revista de Educação e Pesquisa em Contabilidade: Brasília, v. 9, n. 2, p. 124-142, abr./jun. 2015. Disponível em: http://www.repec.org.br/repec/article/view/1141. Acesso em: 18 maio 2019.

[5] FRITSCH, Rosangela. et al. A evasão nos cursos de graduação em uma instituição de ensino superior privada. Revista Educação em Questão: Natal, v. 52, n. 38, p. 81-108, maio/ago. 2015. Disponível em: https://periodicos.ufrn.br/educacaoemquestao/article/view/7963/5724. Acesso em: 18 maio 2019.

[6] LOPES, João Cleber de Souza. Evasão nos cursos de graduação em ciências contábeis em instituições de ensino superior da região sul do Brasil. 2014. 114 f. Dissertação (Mestrado em Ciências Contábeis) - Universidade do

Vale dos Sinos, $\quad$ São $\quad$ Leopoldo, $2014 . \quad$ Disponível http://www.repositorio.jesuita.org.br/bitstream/handle/UNISINOS/4154/Jo\%c3\%a3o\%20

[7] Cleber\%20de\%20Souza\%20Lopes.pdf?sequence=1\&isAllowed=y. Acesso em: 9 maio 2019.

[8] TINTO, Vincent. Dropout from higher education: a theoretical synthesis of recent research. New York: Columbia University, 1975.

[9] TINTO, Vincent. Classrooms as communities: exploring the educational character of student persistence. Columbus: Journal of Higher Education, 1997.

[10] TINTO, Vincent. Leaving college: rethinking the causes and cures of student attrition. Chicago: University of Chigago Press, 1993. 


\section{Capítulo 16}

O programa de aprendizagem cooperativa em células estudantis e a evasão estudantil no campus Russas da Universidade Federal do Ceará

\section{Gabrielle dos Santos Marques}

Dmontier Pinheiro Aragão Júnior

Marcos Ronaldo Albertin

Leonardo Melo Bezerra

Resumo: Durante os primeiros anos da graduação muitos estudantes se encontram alheios a possibilidade de aprender uns com os outros, a dificuldade de adaptação à vida acadêmica causa a evasão de muitos desses estudantes. 0 Programa de Aprendizagem Cooperativa em Células Estudantis (PACCE), da Universidade Federal do Ceará (UFC), busca diminuir a evasão por meio de células de estudo que utilizam uma metodologia de aprendizagem cooperativa. As células se propõem a abreviar esse período de adaptação dos estudantes à esta nova fase, criando afinidades entre os alunos e incentivando o compartilhamento de conhecimento. Os estudantes em sua maioria têm as mesmas dificuldades iniciais, que vão desde não conseguir acompanhar as disciplinas do curso até não saber em que área desejam atuar no mercado de trabalho. A presente pesquisa foi realizada no Campus Russas da UFC, sendo voltada para a análise dos fatores determinantes no processo de evasão, demonstrou que o fortalecimento da cultura cooperativa contribuiu para o bom desempenho acadêmico e promoveu o desenvolvimento de relações positivas entre os estudantes que participaram do PACCE. Dentro de um ambiente em que os estudantes anseiam por saber mais sobre o futuro que os aguarda e sentem a necessidade de superar os obstáculos apresentados, foi possível observar a relevância dessa iniciativa, onde através de pesquisa e cooperação, o que é aprendido é propagado como forma de difusão de ideias.

Palavras-chave: Evasão estudantil; Aprendizagem cooperativa; Campus Russas. 


\section{INTRODUÇÃO}

A Universidade Federal do Ceará (UFC), como parte da política nacional de expansão da educação superior, criou um novo Campus no município de Russas. 0 processo de expansão da UFC na direção do interior do estado vem responder às antigas demandas da sociedade. 0 objetivo do campus é formar profissionais da mais alta qualificação, gerar e difundir conhecimentos, preservar e divulgar os valores artísticos e culturais, constituindo-se em instituição estratégica para o desenvolvimento da cidade de Russas e região do Vale do Jaguaribe (UFC, 2016).

Muitos alunos não possuem um núcleo familiar permanente em Russas e precisam se mudar para residirem no município onde está situada a universidade. Nesses casos, as dificuldades em arcar com despesas como aluguel, fazem com que alguns sejam desestimulados a permanecer. Dentre os fatores que influenciam na decisão de evadir está a dificuldade de adaptação a vida acadêmica. Segundo Bardagi \& Hutz (2012), a integração do estudante no meio social da universidade ocorre através da convivência em atividades extracurriculares e nas interações com o corpo docente.

A precária formação escolar de muitos alunos, devido à deficiência do sistema de ensino a que tiveram acesso, é fator determinante das dificuldades por eles enfrentadas (MEC/SESU, 1996). A evasão desses estudantes são desperdícios sociais, acadêmicos e econômicos. No setor público, são recursos públicos investidos sem o devido retorno e no setor privado, é uma importante perda de receitas. A evasão é ainda uma fonte de ociosidade de professores, funcionários, equipamentos e espaço físico (SILVA FILHO et al., 2007).

A Pró-reitoria de Graduação da UFC - PROGRAD - implementou em 2009, o Programa de Aprendizagem Cooperativa em Células Estudantis - PACCE. Esse Programa tem como objetivos gerais: a proposta de contribuir para o aumento da taxa de conclusão e do sucesso acadêmico discente; a formação de capital social a partir do capital intelectual discente da UFC; o aumento da sinergia entre cursos e unidades acadêmicas da UFC; e a formação de profissionais competentes, proativos e habilitados para o trabalho em equipe (VIEIRA, 2015).

O PACCE utiliza os cinco pilares propostos pelos irmãos Johnson e Johnson (1999): interdependência positiva, responsabilização pessoal, interação promotora, habilidades sociais e processamento de grupo. As estruturas dos encontros de célula são montadas de tal forma que haja interdependência positiva, ou seja, cada membro assume sua parte no projeto para que todos possam alcançar um objetivo em comum. Há uma forte relação entre todos os pilares, mas a interpendência positiva torna-se o ponto de referência para todos eles (VIEIRA, 2015). Seguindo assim a citação do filósofo chinês Confúcio (500 a.C.): "O que eu ouço, eu esqueço; o que eu vejo, eu lembro; o que eu faço, eu compreendo.".

O sucesso e a gratificação em atividades extracurriculares influem na avaliação geral do indivíduo sobre os custos e benefícios de estar na universidade, modificando a sua experiência educativa e o seu comprometimento institucional (Bardagi \& Hutz, 2012). O PACCE foi implementado no Campus Russas em 2016 e busca contribuir de forma a incentivar o compartilhamento de conhecimento e experiências, difundindo a cultura cooperativa no combate à evasão estudantil.

Bardagi \& Paradiso (2003) observaram que a participação em atividades acadêmicas está associada à satisfação com a escolha profissional; observaram, ainda, que o fato da maioria dos alunos não participar de atividades acadêmicas pode contribuir para uma falta de informações realistas a respeito da profissão escolhida.

A pesquisa, buscou mensurar os principais aspectos que influenciam a evasão de alunos em um campus do interior, através da aplicação de um questionário observou-se quais os principais aspectos que levam um aluno a desistir da graduação. Além disso, observou-se como o PACCE tem contribuído para a redução desses níveis de evasão.

\section{OBJETIVO}

Esta pesquisa se propõe a mensurar a intervenção do PACCE no combate à evasão no Campus Russas e sua influência nos estudantes já alcançados, identificando os aspectos que levam os estudantes à evasão no Campus Russas da Universidade Federal do Ceará. 


\section{METODOLOGIA}

Para a realização desta pesquisa, foi desenvolvido e aplicado um formulário com o fim coletar dados quantitativos dos fatores de maior influência na decisão de evadir, além da realização de entrevistas com os estudantes envolvidos no programa.

Para obtenção de maiores informações, foi realizada inicialmente uma pesquisa com os alunos do Campus Russas, onde foram listados 17 potenciais fatores de influência na decisão dos estudantes de evadir, os seguintes aspectos foram elencados a partir das sugestões dos alunos: (1) pouca participação em atividades extracurriculares, (2) muitas reprovações, (3) mudança de curso, (4) inadaptação a vida universitária, (5) falta de programas de incentivo a permanência, (6) falta de preparação no ensino médio, (7) falta de orientação vocacional e profissional, (8) fata de didática dos professores, (9) estrutura física insuficiente do campus, (10) estrutura curricular vigente insatisfatória, (11) distância da família, (12) dificuldade de conciliar universidade e trabalho, (13) dificuldade financeira, (14) desvalorização da profissão, (15) desmotivação com o curso, (16) baixa integração social dentro do campus, (17) baixa integração entre universidade e mercado de trabalho. Ver estrutura do formulário aplicado no Apêndice A.

0 formulário foi proposto utilizando uma escala Likert de 5 pontos, variando entre: muito dificilmente, dificilmente, indiferente, provavelmente e muito provavelmente. Uma escala tipo Likert é composta por um conjunto de frases em relação a cada uma das quais se pede ao sujeito que está a ser avaliado para manifestar seu grau de concordância (CUNHA, 2007). Sendo a atitude não observável, pode somente ser inferida por meio de indicadores, como por intermédio da escala Likert.

A pesquisa foi veiculada em salas de aula, em um período total de duas semanas. E a tabulação foi realizada através da ferramenta Google Formulários e a análise dos dados foi efetuada com auxílio do software Excel.

Após a análise dos dados foram realizadas entrevistas individuais com os alunos alcançados pelo PACCE através das seguintes células de estudo em aprendizagem cooperativa: Álgebra Linear, Mecânica em Grupo, Cálculo Fundamental, Colocação no Mercado e Segurança da Informação. Nessas entrevistas, foi solicitado que eles respondessem um questionário previamente elaborado, contendo questões relativas a contribuição do PACCE para sua permanência na universidade. A partir das respostas obtidas, pôde-se compor observações que possibilitaram o entendimento da intervenção do programa na inibição dos fatores relacionados na pesquisa previamente realizada.

\section{RESULTADOS}

Ao final da fase de aplicação do formulário foram obtidas um total de 277 respostas, alcançando alunos de todos os cinco cursos presentes no Campus Russas. Em relação ao semestre de ingresso, $73 \%$ das respostas são de alunos ainda no primeiro ano de curso, de acordo com Silva Filho et al. (2007) verifica-se, em todo o mundo, que a taxa de evasão no primeiro ano de curso é duas a três vezes maior do que a dos anos seguintes. Assim, este trabalho coletou os dados dos principais alunos alvos desta pesquisa, os alunos ingressantes.

Através dos dados coletados foi definido o termo "indicativo de evasão" para se referir a soma das indicações: provavelmente e muito provavelmente; presentes para cada um dos fatores influenciadores analisados em escala Likert no formulário. Ao analisar os fatores individualmente foi possível observar como tendo maior influência os seguintes aspectos: dificuldade financeira, muitas reprovações e falta de programas de incentivo a permanência; como mostra a Figura 1, onde os valores rotulados apontam o indicativo de evasão de cada fator. 
Figura 1 - Influência dos fatores da decisão de evadir.

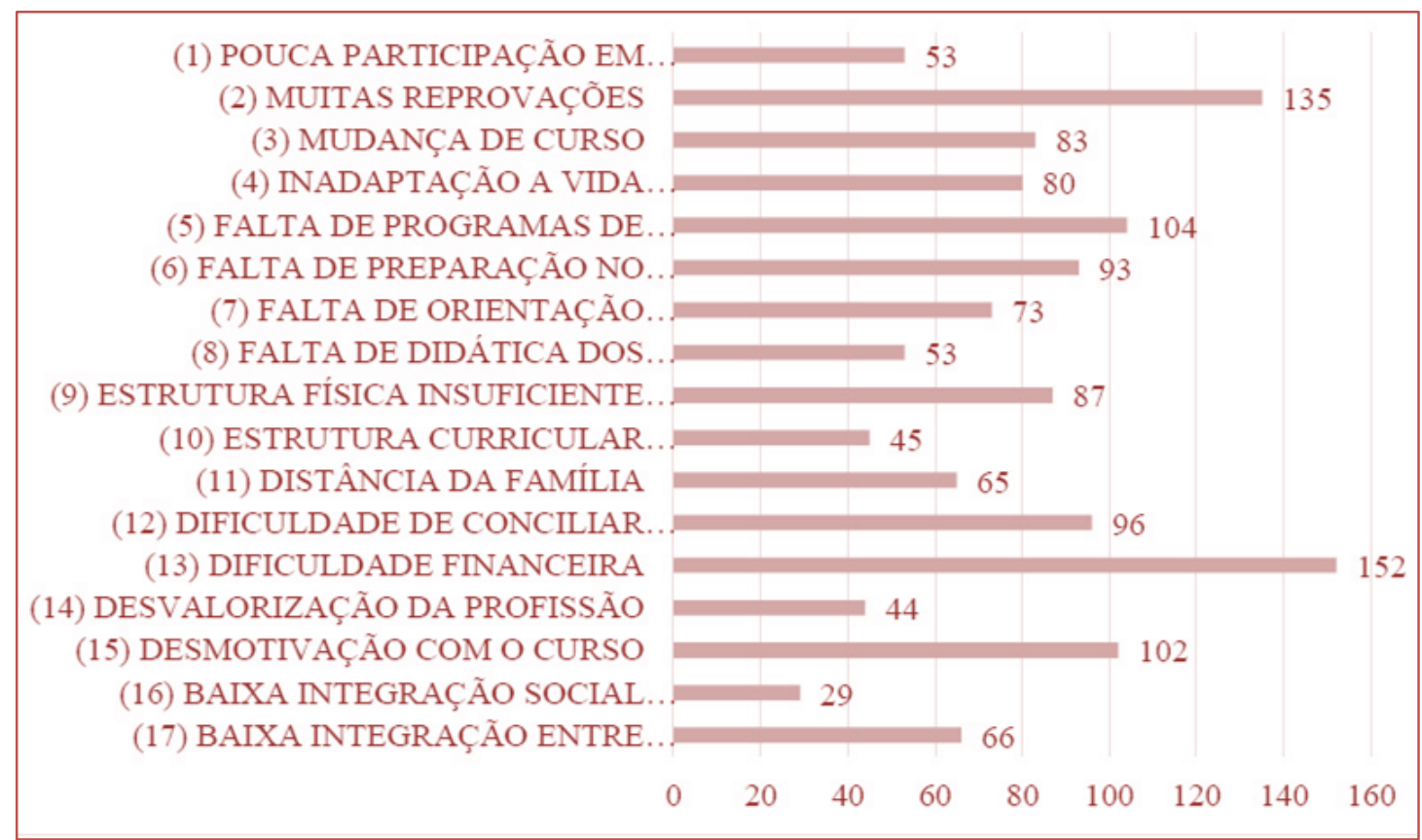

Fonte: Elaborada pelo autor.

As entrevistas foram realizadas com 16 alunos, dentre eles bolsistas do PACCE e participantes de células. A respostas obtidas retornaram como mais citados os seguintes aspectos, com relação a contribuição do programa em sua permanência na universidade: aumento do desempenho acadêmico, maior integração social, sentimento de motivação em relação a participação em atividades extracurriculares e ampliação da visão das áreas de atuação de seu curso.

Sentir-se parte do ambiente e do novo grupo é fundamental para a consolidação da identidade profissional, sentir-se afastado do grupo em relação a interesses, valores, expectativas e rotinas de vida pode levar a uma percepção de inadequação geral, aumentando a probabilidade de abandono e desengajamento acadêmico (BARDAGI \& HUTZ, 2012).

O PACCE tem sua intervenção nos fatores observados na Figura 2, de acordo com as entrevistas conduzidas com os estudantes envolvidos.

Figura 2 - Fatores de intervenção do PACCE.

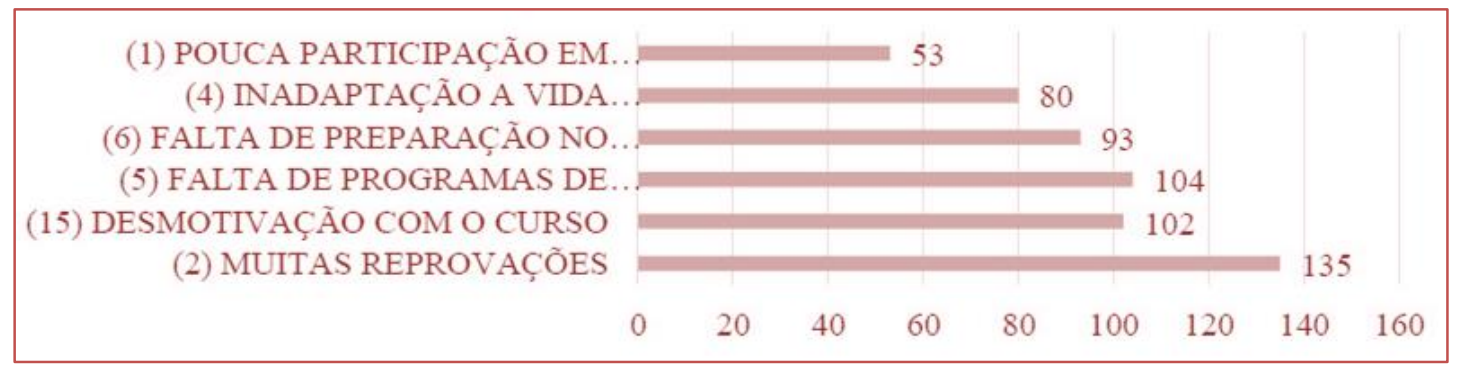

Fonte: Elaborada pelo autor.

0 fator referente a pouca participação em atividades extracurriculares tem um indicativo de evasão de $19 \%$ conforme o apontado na pesquisa realizada. Para os estudantes envolvidos no programa, essa causa é inibida pelo sentimento de motivação proporcionado pela atuação dentro das células. 0 mesmo efeito é relatado em relação fator que se refere a falta de programas de incentivo a permanência, tendo esse um indicativo de evasão de $37 \%$. 
0 aspecto que se refere a inadaptação a vida universitária tem um indicativo de evasão de $28 \%$ de acordo com a análise dos dados obtidos na pesquisa, sendo esse fator contido pelo PACCE que através das atividades de interação promove uma maior integração social, segundo relatos obtidos por meio das entrevistas realizadas.

0 fator referente a falta de preparação no ensino médio tem um indicativo de evasão de 34\%, o aspecto que se refere as muitas reprovações chega a ter um indicativo de evasão de $49 \%$ conforme o apontado na pesquisa realizada. Os estudantes envolvidos no programa mencionaram em entrevista que tiveram seu desempenho acadêmico aumentado pelo suporte oferecido nas células de estudo de disciplinas de seus cursos.

O tópico que se refere a desmotivação com o curso aparece com um indicativo de evasão de 37\% e é inibido pelo PACCE por meio ampliação da visão das áreas de atuação do curso, de acordo com os estudantes participantes de células de estudo voltadas para a atuação profissional.

\section{CONSIDERAÇÕES FINAIS}

A abordagem do tema relacionado a evasão tem como base a proposta do Programa de Aprendizagem Cooperativa em Células Estudantis de contribuir com o aumento da taxa de conclusão e sucesso acadêmico dos estudantes. A proposta em questão foi no ano de 2016 estendida ao Campus Russas, contribuindo com a formação e integração de diversos estudantes que tiveram a oportunidade de conhecer o programa, seja na posição de bolsistas, membros ou visitantes das células atuantes.

O suporte oferecido pelas células de estudo se mostrou relevante para o êxito acadêmico nas disciplinas trabalhadas, produto alcançado por meio do reforço dos conteúdos repassados em sala de aula. Os participantes das células que adotam essa vertente relataram a importância de ter um grupo de estudo programado para a melhoria de seu desempenho dentro da universidade.

A participação no PACCE despertou os estudantes para a relevância de participar de atividades extracurriculares e fez com que esses alunos se sentissem parte da universidade. O programa integrou alunos de diversos cursos e proporcionou o compartilhamento de experiências e a formação de vínculos entre os estudantes, ao mesmo tempo em que os desenvolveu socialmente.

Assim, pode-se concluir que o Programa de Aprendizagem Cooperativa em Células Estudantis se mostrou efetivo no incentivo ao compartilhamento de conhecimento, os alunos participantes relataram inciativas de aprendizado cooperativo mesmo fora das propostas das células, demonstrando o sucesso da proposta e seu potencial para integrar pessoas e, consequentemente, reduzir os níveis de evasão no Campus Russas.

\section{AGRADECIMENTOS}

Os autores agradecem ao Programa de Aprendizagem Cooperativa em Células Estudantis pela experiência proporcionada.

\section{REFERÊNCIAS}

[1] BARDAGI, Marucia Patta; HUTZ, Claudio Simon. Rotina acadêmica e relação com colegas e professores: impacto na evasão universitária. Psico, 2012, 43.2.

[2] BARDAGI, Marúcia Patta; PARADISO, Ângela Carina. Trajetória acadêmica e satisfação com a escolha profissional de universitários em meio de curso. Revista Brasileira de Orientação Profissional, 2003, 4.1-2: 153-166.

[3] CUNHA, Luísa Margarida Antunes da, et al. Modelos Rasch e Escalas de Likert e Thurstone na medição de atitudes. 2007.

[4] JOHNSON, David W.; JOHNSON, Roger T.; HOLUBEC, Edythe Johnson. El aprendizaje cooperativo en el aula. Buenos Aires: Paidós, 1999.

[5] MEC/SESU. Comissão Especial de Estudos sobre a Evasão nas Universidades Públicas Brasileiras. Brasília: ANDIFES/ABRUEM/SESU/MEC. 1996.

[6] SILVA FILHO, Roberto Leal Lobo, et al. A evasão no ensino superior brasileiro. Cadernos de pesquisa, 2007, 37.132: 641-659. 
[7] UFC - CAMPUS RUSSAS. O Campus. Disponível em: http://www.campusrussas.ufc.br/campus.php. Acesso em: 16 de outubro de 2016.

[8] VIEIRA, Hermany Rosa. Avaliação do processo de ensino e aprendizagem entre articuladores de células do Programa de Aprendizagem Cooperativa em Células Estudantis da Universidade Federal do Ceará. 2015. 


\section{Capítulo 17}

Da universidade ao mercado de trabalho: Análise de aspectos para a contratação e desenvolvimento de carreira dos Engenheiros

Filipe Molinar Machado

Franco da Silveira

Luis Cláudio Villani Ortiz

Bruno Miranda dos Santos

Paulo Cesar Chagas Rodrigues

Resumo: 0 presente trabalho objetiva verificar os aspectos essenciais de contratação e de carreira dos engenheiros dentro da empresa com base em estudos realizados pela Confederação Nacional da Indústria - CNI, haja vista que a análise do perfil técnico das empresas, observado nos dias de hoje, aponta para a utilização gradativa de novas tecnologias com a finalidade de obter vantagens em um mercado globalizado e altamente competitivo. Porém, mesmo o estudo do perfil técnico não é sinônimo de vantagem competitiva para a empresa. Assim, dentre outros fatores, devemos concentrar a atuação nas pessoas que farão o intercâmbio entre os elementos técnicos e a vantagem competitiva da empresa. Alguns fatores importantes devem ser respondidos nessa visão de intercâmbio, tais como: como é realizada a contratação de um engenheiro e quais os critérios observados? Quais são os programas que as empresas desenvolvem para atrair jovens engenheiros? Há programas de retenção de engenheiros? Trata-se de uma pesquisa bibliográfica, quantitativa em função do problema, exploratória de acordo com o objetivo. Por fim, com esse trabalho, pretendemos explorar, de forma concisa, o que as empresas buscam, ou desejam, de futuros profissionais da área de engenharia, quais são as oportunidades que as universidades devem estabelecer em suas prioridades educacionais a fim de formar engenheiros capazes de realizar a ponte entre o perfil técnico e a vantagem competitiva almejada pelas empresas.

Palavras-chave: Mercado de trabalho, Engenharia, Educação. 


\section{INTRODUÇÃO}

0 grande número de projetos nos setores de petróleo, construção civil, infraestrutura e metal-mecânica tem provocado uma busca frenética por engenheiros no Brasil. Eventos como a Copa e as Olimpíadas vão exigir um grande número de obras de infraestrutura, enquanto projetos como a construção da usina de Belo Monte e o programa Minha Casa, Minha Vida vão incrementar o segmento de gerenciamento de projetos.

Assim, dentro de um cenário transformativo e, consequentemente, do mercado de trabalho, vem-se consolidando no Brasil a necessidade de empreender. No contexto de um ambiente caracterizado por um dinâmico movimento tecnológico, coloca-se, claramente, um desafio relativo à qualificação das pessoas para atuarem de forma efetiva na sociedade, como agentes de mudanças e como parceiros na criação de novas possibilidades.

Diante destes fatores, a intervenção pedagógica assumida pela Universidade é de fundamental importância no desenvolvimento de cidadãos empreendedores, capazes de aprender a aprender, pois atualmente há necessidade de uma educação para a vida, ou seja, uma formação continuada. Porém, trazendo essa intervenção pedagógica para dentro da Universidade, especificamente para a área das engenharias, dentre as várias perguntas de interesse, uma se destaca: como é realizada a contratação de um engenheiro e quais os critérios observados nessa dinâmica empreendedora atual? Dentro da ideia de analisar os aspectos observados quando da contratação de engenheiros e o que pode e deve ser avaliado/melhorado pelas instituições formadoras destes profissionais, está a proposta essencial deste trabalho.

\section{METODOLOGIA}

A estruturação metodológica para a presente pesquisa está organizada de acordo com o modelo proposto por QUIVY e CAMPENHOUDT (1992) para a investigação social, ou seja, a análise cujo objetivo é "compreender mais profundamente e interpretar mais acertadamente os fenômenos da vida coletiva" com que os estudiosos, seja por "responsabilidades profissionais ou sociais", se confrontam. 0 critério escolhido para constituir a análise do presente trabalho foi por intermédio de estudos e entrevistas sobre a estrutura empresarial brasileira e no mercado de trabalho dos engenheiros realizadas pela Confederação Nacional da Indústria (CNI). Adotamos tal procedimento metodológico por entender que a CNI possui amplo rol legal de intermediação com as empresas, haja vista esta ser, como o próprio nome indica, a Confederação das Indústrias no Brasil.

Assim, para poder dimensionar e entender o mercado de trabalho de engenharia no Brasil é preciso analisar, em primeiro ligar, a estrutura do mercado empresarial brasileiro e, em segundo lugar, a estrutura do mercado de empresas que contrata engenheiros. A "Tabela 1" exibe a quantidade de entrevistados, a forma e data de coleta, os instrumentos de coleta e os tipos de empresas bases do trabalho desenvolvido pela CNI.

Tabela 1 - Estrutura empresarial brasileira e mercado de trabalho (CNI).

\begin{tabular}{|c|c|c|c|c|c|}
\hline Descrição & até 49 empregados & $50-249$ & $250-499$ & 500 ou mais & TOTAL \\
\hline $\begin{array}{l}\text { Total de empresas (Cadastro } \\
\text { Central de Empresas } 2005 \text { - } \\
\text { IBGE) }\end{array}$ & 5.602 .381 & 50.736 & 7.526 & 7.360 & 5.668 .003 \\
\hline$\%$ do total de empresas & $98,84 \%$ & $0,90 \%$ & $0,13 \%$ & $0,13 \%$ & $100 \%$ \\
\hline $\begin{array}{l}\text { Total de assalariados (Cadastro } \\
\text { Central de Empresas } 2005 \text { - } \\
\text { IBGE) }\end{array}$ & 9.850 .592 & 4.987 .021 & 2.607 .345 & 14.779 .282 & 32.224 .240 \\
\hline$\%$ do total de assalariados & $30,57 \%$ & $15,48 \%$ & $8,09 \%$ & $45,86 \%$ & $100 \%$ \\
\hline $\begin{array}{l}\text { Salário e outras remunerações } \\
\text { em R\$ } 1.000,00 \text { (Cadastro } \\
\text { Central de Empresas } 2005 \text { - } \\
\text { IBGE) }\end{array}$ & 76.988 .230 & 57.910 .677 & 34.766 .834 & 274.586 .870 & 444.252 .611 \\
\hline$\%$ do total de remunerações & $17,33 \%$ & $13,04 \%$ & $7,83 \%$ & $61,81 \%$ & $100 \%$ \\
\hline $\begin{array}{l}\text { Total de engenheiros (CAGED } \\
30 / 01 / 2007 \text { ) }\end{array}$ & 21.930 & 30.267 & 16.542 & 60.086 & 128.825 \\
\hline $\begin{array}{l}\% \text { do total de engenheiros } \\
\text { contratados }\end{array}$ & $17,02 \%$ & $23,49 \%$ & $12,84 \%$ & $46,64 \%$ & $100 \%$ \\
\hline
\end{tabular}


Dada à diversidade de ramos de atividade e a distribuição não homogênea da contratação de engenheiros, seja por porte seja por ramo de atividade, optamos por selecionar e agrupar ramos de atividade que fosse mais relevante para sua atuação e interesses de momento. Diante da "Tabela 1", este estudo trata-se de uma pesquisa de cunho exploratório, de natureza básica, quantitativa em função do problema, exploratória de acordo com o objetivo.

\section{ANÁLISE DA ENTRADA DE ENGENHEIRO NO MERCADO DE TRABALHO}

O caminho mais comum para entrada dos engenheiros na empresa é pela participação em programas de estágio (junto com o estudo) ou após um período como trainee. A necessidade de estágios é apontada como crucial como forma de superar a barreira da falta da prática no ensino de engenharia. A empresa é vista como participante do processo de formação real do engenheiro para as necessidades do mercado. Quando se fala nas correções ou ajustes que a educação de engenharia deveria sofrer, a questão da prática aparece sempre com destaque. A necessidade de estágios é tão grande que são poucos os engenheiros que se formam no tempo mínimo de cinco anos, face à necessidade de dividir o tempo entre estudos e estágios se quiserem ter chances reais de bons empregos quando formados.

Figura 1 - Tempo de vínculo empregatício do engenheiro na empresa (CNI).

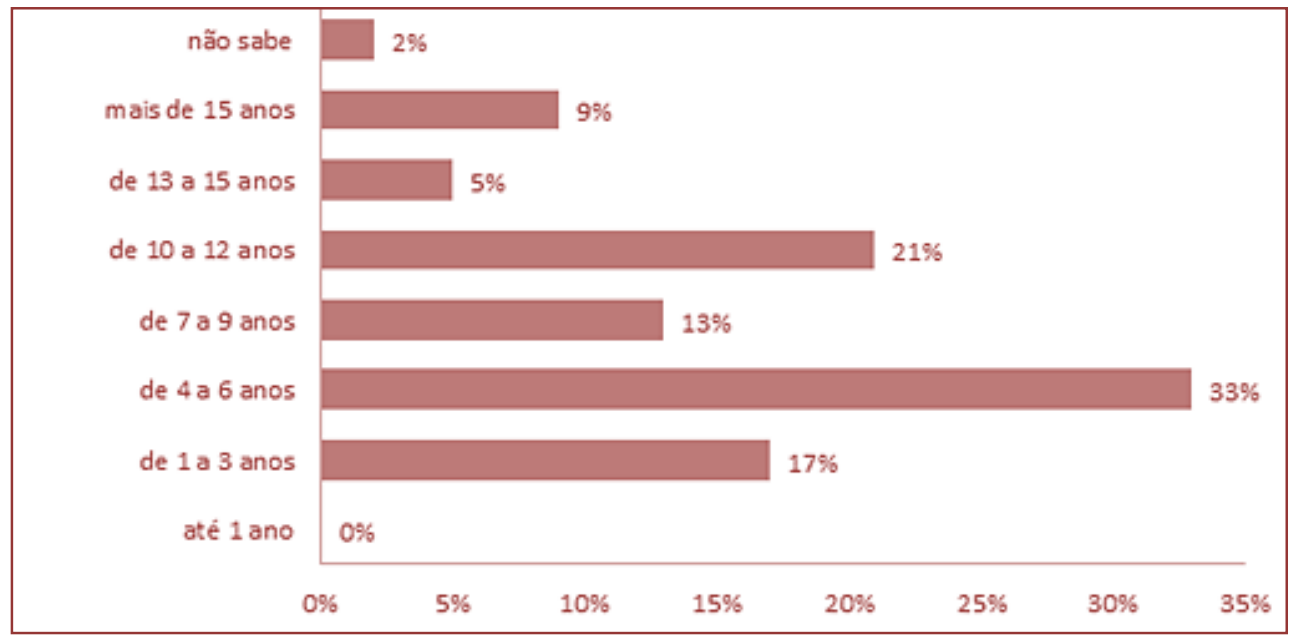

Se a entrada nas empresas depende de um período de estágio e treinamento, a permanência dependerá cada vez mais de atualização e adaptação a novas técnicas e tecnologias ("Figura 1"). No panorama atual, um engenheiro pode esperar mudar de emprego 4 vezes entre a formatura e a aposentadoria, já que seu tempo de permanência médio na empresa é de 8,2 anos.

Figura 2 - Análise da contratação de engenheiro (CNI).

\begin{tabular}{|c|c|c|c|c|}
\hline \multirow{3}{*}{$\begin{array}{l}\text { Há programas de atraçăo de engenheiros em final de } \\
\text { formaçăo ou recém-formados? } \\
\text { Há treinamento específico do recém-contratado? }\end{array}$} & $18 \%$ & \multicolumn{2}{|c|}{$82 \%$} & \multirow{5}{*}{$\begin{array}{l}\square \operatorname{sim} \\
\square \text { não }\end{array}$} \\
\hline & $21 \%$ & \multicolumn{2}{|c|}{$79 \%$} & \\
\hline & \multicolumn{2}{|c|}{$41 \%$} & $59 \%$ & \\
\hline Contrata como estagiário ou trainee? & \multicolumn{2}{|r|}{$64 \%$} & $36 \%$ & \\
\hline Contrata engenheiro recém-formado? & \multicolumn{2}{|c|}{$89 \%$} & $11 \%$ & \\
\hline
\end{tabular}


Mesmo com programas de estágios e de trainees ("Figura 2"), 41\% das empresas ainda declaram realizar programas de treinamento específicos para os engenheiros recém-contratados. Por outro lado são relativamente poucas as que têm programas de atração de engenheiros recém-formados ou prestes a se formarem. A integração na empresa tende a começar mais cedo. Também é pequena a proporção de empresas que têm programas de retenção de engenheiros. Até recentemente, o mercado de trabalho não tinha problemas de oferta de mão-de-obra. Com o aquecimento da economia e em setores específicos como energia, mineração, petróleo, construção, telecomunicações e metal-mecânica, por exemplo, passou a haver escassez de engenheiros qualificados e experientes.

Nas grandes empresas (1.000 funcionários ou mais), os programas de contratação de estagiários ou trainees, de atração de recém-formados ("Figura 3") ou de retenção de engenheiros são menos frequentes, provavelmente por terem mais facilidade de contratação de engenheiros mais experientes. Fora dos eixos industriais mais tradicionais, também são menos frequentes os programas de estágios, trainees e atração de recém-formados.

Dentre as formas de atração de jovens engenheiros, há três dominantes:

- $\quad$ Estágios remunerados: $35 \%$

- Parceria e integração com escolas: $22 \%$

- Programas de trainees: $21 \%$

Figura 3 - Programas que as empresas desenvolvem para atrair jovens engenheiros (CNI)

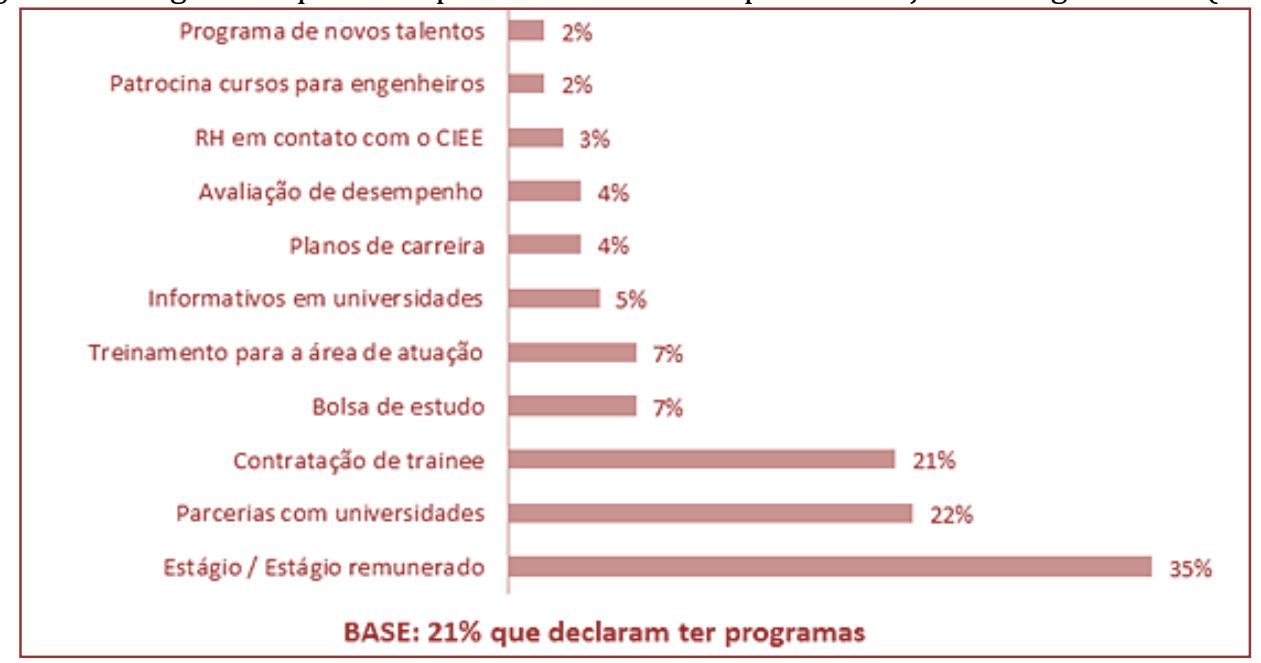

É interessante a proporção de empresas que está adotando a parceria com escolas ("Figura 3"). Pelas sugestões para melhoria do ensino de engenharia no Brasil, essa parceria é uma forma de introduzir o aluno a práticas importantes para as empresas já durante o processo de formação, superando, em parte a falta de equipamentos e laboratórios nas escolas. De alguma forma ajuda, ainda, a superar as alegadas deficiências de corpos docentes afastados do mercado ou sem a prática necessária.

Os problemas que a falta de ensino voltado para o mercado ocasionam, levam $41 \%$ das empresas a oferecerem treinamento dentro e fora da empresa, com três propósitos principais, conforme exibe a "Figura 4": adaptação a processos e produtos específicas da empresa, certificação de qualidade (ISO) e complementação em áreas não relacionadas à engenharia (administração, finanças, relacionamento humano, liderança, vendas e uso de softwares). 
Figura 4 - Treinamentos oferecidos a engenheiros recém-formados (CNI).

BASE: $41 \%$ que oferecem esses tipos de programas.

\section{TREINAMENTO NA EMPRESA (55\%)}

Treinamento direcionado à situação específica da empresa (15); treinamento para controle e certificação de

qualidade (14); treinamento para adaptação à cultura da empresa (4); treinamento externo (4).

\section{CURSOS E TREINAMENTO FORA DA EMPRESA (56\%)}

Cursos em áreas específicas não relacionadas à empresa (24); planejamento, administração e orçamento (12); cursos sobre produtos da empresa (7); cursos básicos nas áreas de atuação da empresa (5); cursos de softwares gerais (5); habilidades comerciais e de vendas (5); cursos de segurança do trabalho (4); cursos de liderança e RH (4); cursos em processos específicos da empresa (3).

\section{PALESTRAS, SEMINÁRIOS E CONGRESSOS $(8 \%)$}

Palestras de convidados (4); participação em seminários (3); participação em congressos (1).

Os programas de retenção de engenheiros ("Figura 5") procuram resolver o problema de ascensão do engenheiro a postos mais altos dentro da administração da empresa. Como o engenheiro é, na maioria das vezes, usado em funções mais técnicas, chega uma hora em que ele bate num "teto" dentro da empresa. Para resolver esse problema e não perder os engenheiros já treinados e adaptados à empresa, muitas delas têm planos de carreira e salariais específicos para os engenheiros, baseados em avaliação de desempenho.

Uma segunda forma de retenção é feita pela distribuição de lucros, aumentos salariais por tempo de empresa e bônus associados ao desempenho da empresa como um todo.

Um terceiro bloco de incentivos consiste em bolsas de estudo para extensão, treinamentos específicos no ramo de atividade, cursos de línguas, cursos no exterior e treinamento em habilidades não diretamente relacionadas à engenharia.

Figura 5 - Programas de retenção de engenheiros (CNI).

BASE: $18 \%$ que oferecem esses tipos de programas. PROMOÇÃO E AVALIAÇÃO POR MÉRITO (46\%)

Plano de carreira e salarial (35); Avaliação de desempenho (13); Retenção de talentos (1).

SALÁRIOS, BÔNUS E DISTRIBUIÇÃO DE LUCROS (38\%)

Distribuição de lucros (12); Aumento salarial (11); Salários acima do mercado (10); Plano de bônus baseado no desempenho da empresa (7).

\section{BENEFÍCIOS ADICIONAIS (24\%)}

Palestras de convidados (4); Participação em seminários (3); Participação em congressos (1). TREINAMENTO (16\%)

Treinamento específico no ramo de atividade (14); Treinamento no exterior (3). CURSOS (14\%)

Cursos no ramo de atividade (7); Cursos de liderança (3); Cursos de análise de risco (2); Cursos de línguas (1);

Outros cursos (3).

BOM AMBIENTE DE TRABALHO (4\%)

Investimento em ambiente de trabalho agradável (3); Escolha de tarefas e rotação de funções (2).

A "Tabela 2" ilustra o baixo número de engenheiros que consegue ascender a altos e médios cargos administrativos, não diretamente relacionados a projetos ou atividades de engenharia, tornando necessários outros esquemas de promoção dentro do campo de atuação específico do engenheiro.

Tabela 2 - Número de engenheiros em cargos vs. faixa de engenheiros empregados (CNI).

\begin{tabular}{|l|c|c|c|c|c|c|c|}
\hline \multicolumn{7}{c}{ Faixa de engenheiros empregados: } \\
\hline \multicolumn{1}{|c|}{$\begin{array}{c}\text { Número absoluto de engenheiros ocupando: } \\
\text { a a } 5\end{array}$} & 6 a 10 & 11 a 50 & 51 a 100 & \multicolumn{2}{c|}{$\begin{array}{c}\text { Mais de } \\
100\end{array}$} & $\begin{array}{c}\text { Média } \\
\text { geral }\end{array}$ \\
\hline $\begin{array}{l}\text { Altos cargos administrativos } \\
\text { (presidências, etc) }\end{array}$ & 0,4 & 1,1 & 1,7 & 3,4 & 8,3 & 1,1 \\
\hline $\begin{array}{l}\text { Cargos médios administrativos } \\
\text { (supervisões) }\end{array}$ & 0,5 & 1,4 & 2,6 & 6,8 & 22,3 & 1,7 \\
\hline $\begin{array}{l}\text { Cargos relacionados à engenharia (direção, } \\
\text { chefia) }\end{array}$ & 0,9 & 1,8 & 3,6 & 6,6 & 20,3 & 2,2 \\
\hline $\begin{array}{l}\text { Diretamente ocupados em atividades de } \\
\text { engenharia }\end{array}$ & 1,5 & 2,7 & 10,9 & 32,6 & 80,5 & 6,2 \\
\hline
\end{tabular}


Se, hoje, o engenheiro ainda enfrenta restrições, que o colocam dentro de um plano de carreira mais técnico (com exceção da engenharia de produção), as demandas do mercado para a contratação de engenheiros e alterações sugeridas no ensino da engenharia indicam uma valorização cada vez maior do profissional que traga na bagagem experiência ou cursos relacionados à administração de empresas, finanças, habilidade no tratamento dos recursos humanos e gerenciamento de projetos. Ao mesmo tempo em que querem conhecimento aprofundado na área de atuação, processos e produtos específicos da empresa, as empresas procuram também um profissional de visão mais ampla, dinâmico, que consiga relacionar-se com outras áreas da empresa.

Conforme exibe a "Figura 6", se a experiência e conhecimentos anteriores são os principais critérios de contratação (mencionados por $77 \%$ dos entrevistados), as características pessoais ocupam o segundo lugar (69\% de menções), com destaque para características como:

- Liderança e capacidade de solução de problemas, com habilidades gerenciais (22\%)

- $\quad$ Espírito de equipe a capacidade de trabalhar em grupo (14\%)

- Habilidade no relacionamento humano (12\%)

- Liderança (11\%)

- Iniciativa e disposição para aprender coisas e tarefas novas (11\%)

- $\quad$ Facilidade de comunicação (8\%)

- $\quad$ Facilidade de adaptação a situações novas (6\%)

- Dinamismo e vontade de crescer dentro da empresa (6\%)

Figura 6 - Critérios para contratar engenheiros (CNI).

EXPERIÊNCIA E CONHECIMENTO ANTERIOR DO RAMO (77\%)

Experiência anterior no ramo (41); conhecimento específico do ramo, produtos da empresa (24); conhecimento técnico geral (18); conhecimento de línguas (9); base teórica sólida (8); conhecimento de computação (4); capacidade de desenvolver projetos (2); familiaridade com diversidade de áreas (2); administrar RH (1); habilidade comercial (1).

Espírito de equipe (14); habilidade de relacionamento humano (12); disposição para aprender novas tarefas (11); capacidade de comunicação (8); adaptabilidade (6); vontade de crescer dentro da empresa (6); dinamismo (5). POLÍTICAS DE CONTRATAÇÃO DA EMPRESA (27\%)

Avaliação de currículo (7); realização de concurso (6); entrevista pessoal (4); perfil adequado à empresa (3); referências pessoais (3); empresas que trabalhou/trainee (3); notas escolares (2); tempo em que ficou em empregos anteriores (1); salário esperado (1); testes específicos (1) PERFIL ACADÊMICO (25\%)

Qualidade e reputação da universidade (7); cursos no ramo específico da empresa (9); cursos de especialização e pós-graduação (4). LIDERANÇA E CAPACIDADE DE SOLUÇÃO DE PROBLEMAS (22\%)

Liderança (11); habilidades gerenciais (5); capacidade de identificar e resolver problemas (5); capacidade de aprendizado e adaptação a inovações (4). TRAÇOS PESSOAIS $(9 \%)$

Atitude e comportamento adequados (6); honestidade e ética (4). FLEXIBILIDADE PARA VIAGENS E DE HORÁRIO DE TRABALHO (4\%)

Os fatores personalidade, atitude e comportamento, também aparecem como tão importantes quanto às questões de conhecimento e experiência anteriores, entre as razões para não contratar um engenheiro, como mostra a "Figura 7". Enquanto a falta de conhecimentos e de experiência é citada por 53\%, os problemas de atitude e pessoais recebem $41 \%$ de menções e atitudes e comportamentos inadequados mais $18 \%$. 
Figura 7 - Critérios para NÃO contratar engenheiros (CNI).

FALTA DE EXPERIÊNCIA E CONHECIMENTO ANTERIOR DO RAMO (53\%)

Falta de experiência profissional (21); falta de conhecimento do ramo específico da empresa (19); falta de habilidade e conhecimentos técnicos (18); não fala línguas estrangeiras (4).

\section{PROBLEMAS DE ATITUDE E PESSOAIS (41\%)}

Falta de dinamismo, iniciativa, envolvimento, saber lidar com problemas (22); dificuldade em se relacionar com pessoas (10); referências pessoais negativas, problemas éticos (10); falta de habilidade de trabalhar em grupo e de espírito de equipe (7); dificuldades de comunicação (6); falta de liderança (5). ATITUDE E COMPORTAMENTO INADEQUADOS (18\%)

Problemas de personalidade (4); arrogância (3); desonestidade (3); aparência desleixa (2); pula de emprego em emprego (2); desorganizado (2).

PERFIL ACADÊMICO FRACO (10\%)

Notas baixas, desempenho acadêmico fraco (7); falta de formação na área específica da empresa (4).

\subsection{QUE SE ESPERA DO ENGENHEIRO}

0 engenheiro exerce funções nas mais diversas áreas de uma empresa. Nos setores técnicos, os conhecimentos específicos do engenheiro são importantes; contudo, em outras áreas, essa exigência pode não ser fundamental. As competências pessoais, entretanto, são relevantes em qualquer situação, seja para uma área mais técnica, mais operacional, seja para os demais setores. Conforme demonstrado anteriormente, é esperado que o engenheiro tenha competência em: inovar, focar no cliente, organizar, cooperar, colaborar, empreender, criar, delegar, liderar equipes, relacionar-se com outras pessoas, negociar, resolver problemas, visualizar e analisar o sistema como um todo, gerir equipes técnicas, gerenciar recursos, lidar com situações novas, raciocinar rapidamente, analisar custos, verificar tendências, trabalhar sem supervisão. É claro que, dependendo da função que o engenheiro exerça na empresa, algumas competências são mais valorizadas que outras.

Dentro desse contexto, das competências e habilidades exigidas do engenheiro, podem-se destacar o fato que este profissional deve saber identificar, interpretar, modelar e aplicar tais habilidades à solução de problemas. Desta forma, espera-se que o profissional:

- Disponha de boa comunicação oral e escrita e possua visão crítica;

- Possa efetuar leitura, interpretação e expressão por meios gráficos;

- Possua capacidade de identificar, modelar e resolver problemas;

- Possua conhecimento acerca da legislação pertinente;

- Seja capaz de acompanhar os avanços tecnológicos, organizando-os e colocando-os a serviço da demanda das empresas e da sociedade;

- Seja capaz de compreender a inter-relação dos sistemas de produção com o meio ambiente, tanto no que se refere à utilização de recursos escassos quanto à disposição final de resíduos e rejeitos, atentando para a exigência de sustentabilidade;

- Seja capaz de dimensionar e integrar recursos físicos, humanos e financeiros a fim de produzir considerando a possibilidade de melhorias contínuas;

- Seja capaz de gerenciar e otimizar o fluxo de informação nas empresas;

- Seja capaz de incorporar conceitos e técnicas da qualidade em todo o sistema produtivo;

- Seja capaz de prever a evolução dos cenários produtivos, percebendo a interação entre as organizações e os seus impactos sobre a competitividade;

- Seja capaz de prever e analisar demandas, selecionar tecnologias projetando produtos ou melhorando suas características e funcionalidades;

- Seja capaz de projetar, implementar e aperfeiçoar sistemas, produtos e processos, levando em consideração os limites e as características das comunidades envolvidas;

- Seja capaz de trabalhar em equipes multidisciplinares;

- Seja capaz de utilizar ferramental matemático e estatístico para modelar sistema de produção e auxiliar na tomada de decisões; 
- Seja capaz de utilizar indicadores de desempenho, sistema de custeio, bem como avaliar a viabilidade econômica e financeira de projetos;

- Tenha compromisso com a ética profissional e responsabilidade social e ambiental.

- Tenha domínio das tecnologias de informação e comunicação;

- Tenha domínio de língua estrangeira;

- Tenha iniciativa empreendedora, disposição para auto-aprendizado e educação continuada.

Dentre estas competências esperadas pelo engenheiro, observa-se que várias destas habilidades estão relativamente ligadas à visão e atuação empreendedora. Esta proposição mostra que o grande desafio para as universidades hoje é conseguir detectar quando as transformações ocorrem, para onde estão caminhando essas transformações e, fundamentalmente, conseguir agregar valores tanto nos currículos escolares quanto na prática docente, tudo isso com um tempo de resposta adequado, para não transformar em obsoletas as práticas tradicionais de ensino e por decorrência formar um profissional obsoleto para seu tempo (RESENDE et al., 2003).

\subsection{CONTRIBUIÇÃO DA UNIVERSIDADE NA FORMAÇÃO DO ENGENHEIRO}

A universidade enfatiza os conhecimentos técnicos na formação dos engenheiros. Contribui pouco para o desenvolvimento de competências pessoais dos egressos, pois desenvolvê-las não é um objetivo explícito e planejado da universidade. Por outro lado, as seleções mostram que o campo de atuação do engenheiro não se restringe às atividades técnicas, visto que as empresas desejam desses profissionais muito mais que conhecimento técnico.

É possível entender essa necessidade, pois uma empresa, para se manter competitiva, precisa negociar, ou seja, precisa satisfazer os seus clientes, cumprir prazos, oferecer melhores preços, realizar acordos, etc. Além disso, tem que respeitar as leis do país, preservar o meio ambiente, valorizar seus funcionários, por exemplo. Este é o ambiente em que o engenheiro exerce a engenharia. Neste cenário, a solução de problemas de engenharia ou de desenvolvimento de projetos é complexa. Neste sentido, a melhor proposta de engenharia para a solução de um problema ou a elaboração de um projeto nem sempre é a melhor tecnicamente, mas sim, aquela que melhor atende aos interesses da empresa e de seus clientes.

Conclui-se que o engenheiro tem de ter outro conhecimento além do técnico para atuar neste mercado de trabalho. Entretanto, o foco da graduação em engenharia é na oferta do conhecimento técnico, pouco se preocupando com as competências pessoais (saber relacionar-se, trabalhar em equipe e negociar, e.g.) e as técnicas (conceber, projetar, analisar produtos e processos) necessárias aos engenheiros para que atuem nesse mercado de trabalho.

Por fim, retornando ao campo acadêmico, acrescentamos que deve ser mudado o modelo antigo de educação onde o aluno era preparado para a certeza, onde frequentar uma boa escola e frequentar uma boa universidade garantiria um bom emprego. Isso mudou. Hoje o aluno deve ser preparado para as incertezas. Cabe ao educador analisar como o aluno poderá, na sua vida profissional, arranjar os conhecimentos adquiridos para conseguir novas soluções. Como tornar o desafio futuro uma motivação para sua preparação acadêmica e converter o medo de errar em oportunidades de aprendizagem pela análise criteriosa dos fatores que levaram ao erro. Além disso, os estudos desenvolvidos para descobrir o perfil dos novos líderes em grandes companhias têm como seus dois resultados mais significativos a criatividade e a integridade, dois desafios para os educadores em um mundo altamente padronizado e com valores humanos em questionamento.

\section{CONSIDERAÇÕES FINAIS}

Por meio deste estudo, conclui-se que as Escolas de Engenharia devem se preocupar com a formação empreendedora de seus engenheiros, de forma a prepará-los adequadamente para o mercado de trabalho, situação esta, que atende a legislação vigente no país quanto às competências e habilidades exigidas do engenheiro.

Disciplinas relacionadas com a visão empreendedora devem ser incorporadas na grade curricular e serem alicerçadas pelos projetos político-pedagógicos. Tais atividades, caso integradas e desenvolvidas ao longo 
da graduação, possibilitarão a melhor inserção do futuro engenheiro numa sociedade cada vez mais exigente e em constantes mudanças.

Atividades de práticas gerenciais, como participação em empresas juniores, hospedagem de projetos em hotel tecnológico, competições de AERODESIGN e BAJA e iniciação científica, são exemplos de ações a serem estimuladas ao longo da graduação, como forma de complementação extracurricular das atividades empreendedoras.

Assim, uma instituição de ensino superior deve trabalhar voltada à comunidade em que está inserida, utilizando sua criatividade para encontrar soluções inovadoras para os mais variados problemas sociais, apresentando-se como um agente ativo e transformador da educação.

\section{REFERÊNCIAS}

[1] Confederação Nacional da Indústria - CNI. Mercado de trabalho para o engenheiro e tecnólogo no Brasil. Disponível em: <http://www.cni.org.br> Acesso em: 16 mar. 2011.

[2] Instituto Brasileiro de Geografia e Estatística - Ibge. Cadastro Central de Empresas, 2005. Disponível em: <http://www.ibge.gov.br> Acesso em: 21 mar. 2011.

[3] Ministério do Trabalho e do Emprego - Mte. Cadastro Geral dos Empregados e dos Desempregados - Caged, 2007. Disponível em: <http://www.mte.gov.br> Acesso em: 21 mar. 2011.

[4] Quivy, Raymond; Campenhoudt, Luc Van. Manual de investigação em ciências sociais. Tradução: João Minhoto Marques e Maria Amália Mendes. Lisboa: Gradiva, 1992. 275p.

[5] Resende, L.M.; Dib, S.K. \& Leite, M.G. (2003). Gestão Empreendedora de Carreiras Tecnológicas. cobenge Congresso Brasileiro de Ensino de Engenharia. 


\section{Capitulo 18}

\section{Perfil do engenheiro eletricista - Impactos da formação acadêmica na atuação profissional}

\section{Lucas Vinicios Oliveira Filgueiras \\ Danielly Norberto Araujo \\ Talvanes Meneses Oliveira}

Resumo: As características dinâmicas apresentadas pelo mercado de trabalho exigem de um engenheiro eletricista inúmeras habilidades. Essas habilidades, muitas das vezes, vão além dos conhecimentos obtidos por um profissional especialista. Há muita discussão, portanto, sobre o tipo de formação ideal que deve ser proporcionada aos futuros profissionais dessa área. 0 curso de Engenharia Elétrica da Universidade Federal de Campina Grande (UFCG) disponibiliza aos seus estudantes um tipo de formação fundada em uma base de conhecimentos sólidos e generalistas. Assim, no presente trabalho, uma análise do perfil do profissional formado por essa instituição é realizada. Um questionário foi aplicado aos engenheiros eletricistas egressos com o objetivo de coletar suas opiniões acerca da formação recebida, além de informações da sua atuação profissional.

Palavras-chave: Formação generalista. Engenharia elétrica. Habilidades. Competências. 


\section{INTRODUÇÃO}

A engenharia, segundo Cocian (1990), é a arte da aplicação dos princípios matemáticos, da experiência, do julgamento e do senso comum, para implementar ideias e ações em benefício da humanidade e da natureza. Assim, o engenheiro é um profissional que procura solucionar problemas a partir de conceitos matemáticos e da ciência, mantendo a preservação e conservação ambiental (SALETE et al., 2012).

O desenvolvimento da Engenharia e de seu ensino está diretamente atrelado aos rápidos avanços da ciência, tecnologia e da economia, que impõem a necessidade cada vez maior de conhecimentos e informações sobre novas ferramentas, novas áreas, e novas formas de divisão de trabalho para soluções de problemas.

Nesse sentido, para a formação do engenheiro no Brasil, as Diretrizes Curriculares Nacionais (DCNs) dos cursos de graduação em Engenharia são instituídas na Resolução no 11 de 11 de março de 2002 do Conselho Nacional de Educação (CNE) e determinam que o profissional engenheiro possua formação generalista, humanista, crítica e reflexiva, e seja capacitado a absorver e desenvolver novas tecnologias, com atuação crítica e criativa na identificação e resolução de problemas, considerando seus aspectos políticos, econômicos, sociais, ambientais e culturais, com visão ética e humanística, em atendimento às demandas da sociedade.

No âmbito da Engenharia Elétrica, espera-se do profissional Engenheiro Eletricista uma formação generalista, com sólidos conhecimentos básicos, comuns a todo engenheiro, e com conhecimento profissional da sua área, além de aspectos humanísticos, sociais, éticos e ambientais.

Além disso, segundo a Associação Brasileira de Ensino de Engenharia (ABENGE, 1998), o perfil do Engenheiro Eletricista também deve ter a capacidade de: resolver e analisar problemas com síntese de soluções; elaborar projetos e soluções técnicas economicamente competitivas; absorver novas tecnologias e visualizar, com criatividade, novas aplicações para a Engenharia Elétrica; comunicação e liderança para trabalho em equipes multidisciplinares.

Uma vez que a grande área da Engenharia Elétrica pode ser dividida em cinco áreas de competências interdependentes, sendo elas a eletrotécnica, a eletrônica, as telecomunicações, o controle e automação e a computação, é vasto o número de atividades, habilidades e funções que podem ser atribuídas e realizadas por um Engenheiro Eletricista. Desse modo é exigida uma formação generalista, multidisciplinar e humanística para atender às diferentes solicitações profissionais.

Isto posto, quando egresso de uma IES, são inúmeras as atividades e competências que podem ser atribuídas a um engenheiro eletricista, que passa a ser resultado do currículo proposto no Projeto Pedagógico do Curso (PPC). Logo, a motivação desse trabalho é expor a necessidade de uma formação sólida e completa deste profissional.

Neste artigo, a partir de um questionário aplicado a egressos do curso de Engenharia Elétrica da UFCG, é mostrada a importância da formação generalista, evidenciando que esses engenheiros utilizam tanto os conhecimentos da área de competência em que se especializaram, quanto das demais áreas.

Este trabalho está organizado em 6 seções. Na Seção 2 é descrita a estrutura do curso de Engenharia Elétrica na UFCG. Na Seção 3 é apresentada uma visão geral sobre as novas DCNs homologadas em 2019. Na Seção 4 é apresentada a metodologia utilizada no desenvolvimento do trabalho para então apresentar os resultados na Seção 5. A seção 6 trata sobre as conclusões e considerações finais do trabalho.

\section{O CURSO DE ENGENHARIA ELÉTRICA NA UFCG}

O curso de graduação em Engenharia Elétrica da UFCG do Centro de Engenharia Elétrica e Informática (CEEI), foi criado em 1963, no âmbito da Escola Politécnica da Paraíba (POLI), em Campina Grande, Paraíba. Em 1974, a Escola Politécnica foi absorvida pela estrutura do Centro de Ciências e Tecnologia (CCT) da Universidade Federal da Paraíba (UFPB) e em 1978, houve a implantação da estrutura multicampi na UFPB, com os Centros de Campina Grande passando a constituir o Campus II da Universidade (CGEE, 2004).

Em 2002, a partir do desmembramento da UFPB, a antiga POLI tornou-se UFCG, que já nasceu com uma estrutura multicampi, com centros de ensino nas cidades de Campina Grande, Cajazeiras, Patos e Sousa. Com o processo de expansão, foram criados campus nas cidades de Cuité, Pombal e Sumé, totalizando sete campi (MENDES; BRAGA, 2017). 
No ano de 1999, quando ainda fazia parte da UFPB, o PPC do bacharelado em Engenharia Elétrica da UFCG foi alterado pela Resolução № 20 de 17 de maio de 1999 do Conselho Superior De Ensino, Pesquisa e Extensão da UFPB, que é vigente até os dias de hoje. Nessa resolução, entre outras definições, o curso é ramificado em quatro áreas de competência: a eletrotécnica, a eletrônica, o controle e automação e as telecomunicações.

A especialização em eletrotécnica trata, principalmente, da energia elétrica propriamente dita. Os especialistas dessa área projetam e constroem usinas de geração, linhas de transmissão e redes de distribuição. Além disso, o planejamento e a operação contínua do sistema elétrico são de responsabilidade dessa área de competência. A geração de energia a partir de fontes renováveis aquece o mercado para este setor.

A eletrônica surgiu com a invenção da válvula e tomou força com a chegada do transistor em 1947. A microeletrônica é responsável por projetar, fabricar e testar circuitos integrados (chips) destinados tanto a sistemas de computação e de telefonia, quanto a sistemas de aquisição e transmissão de dados. Já a eletrônica industrial visa aumentar a eficiência energética de dispositivos, equipamentos e máquinas elétricas.

O controle e automação é responsável por controlar plantas e processos industriais, otimizando-os, além de automatizá-los, exigindo uma mão de obra humana cada vez mais qualificada no cenário industrial. A robótica e os estudos de inteligência artificial são os protagonistas dos pesquisadores deste ramo.

O engenheiro eletricista com competência na área de telecomunicações é responsável por desenvolver serviços de expansão de telefonia e de transmissão de dados por imagem e som. Projetar e construir sistemas e equipamentos para telefonia, radiodifusão, redes de comunicação de dados e de processamento digital de sinais. A invenção da fibra ótica revolucionou este ramo da engenharia elétrica.

Assim, a partir da ramificação do curso em quatro áreas de competência e da necessidade do estudante de Engenharia Elétrica adquirir e/ou desenvolver ao longo do curso, compromisso com a ética profissional, responsabilidade social, política e ambiental e espírito empreendedor (ABENGE, 1998), a estrutura curricular vigente teve seus conteúdos curriculares divididos como mostrado na Tabela 1, em que:

- Conteúdos básicos: tem como objetivo realizar a formação científica e tecnológica comum a todo engenheiro, assim como a formação humanística.

- Conteúdos profissionais essenciais: tem como objetivo realizar a formação de conhecimentos básicos e comuns a todo Engenheiro Eletricista, independente da área de competência.

- Conteúdos profissionais específicos: tem como objetivo desenvolver a expertise do Engenheiro Eletricista em alguma das áreas de competência, com aprofundamento de estudos promovido por disciplinas de cunho especialista. Os alunos são orientados a efetuar matrícula nas disciplinas de conteúdos profissionais específicos quando tenham sido executadas as disciplinas dos conteúdos básicos e essenciais (CGEE, 2019).

- Conteúdos complementares: é dividido em formação profissional obrigatória (estágio integrado ou estágio supervisionado, e projeto em engenharia elétrica), formação profissional optativa (tópicos avançados e especiais em engenharia elétrica) e formação geral optativa (com disciplinas como língua portuguesa e prática desportiva, por exemplo).

Tabela 1: Divisão do curso de Engenharia Elétrica na UFCG.

\begin{tabular}{|c|c|c|}
\hline Conteúdos & Carga Horária & № de Créditos \\
\hline Básicos & 1740 & 116 \\
\hline Profissionais essenciais & 1365 & 91 \\
\hline Profissionais específicos & 480 & 32 \\
\hline Complementares & 180 & 6 \\
\hline
\end{tabular}

O curso passou a ter duração mínima de 3.765 horas-atividade, correspondentes a 245 créditos assim distribuídos, que devem ser integralizadas em 9 semestres, no mínimo, e 16, no máximo. 0 número 
máximo e mínimo de créditos por semestre é 28 e 15, respectivamente. Além disso, é definido como sendo 6 o número mínimo de disciplinas profissionais específicas para concluir o aprofundamento dos estudos em uma determinada área de concentração. Na Figura 1 é ilustrado o fluxograma da estrutura curricular.

Figura 1: Fluxograma da estrutura curricular do curso de engenharia elétrica na UFCG.

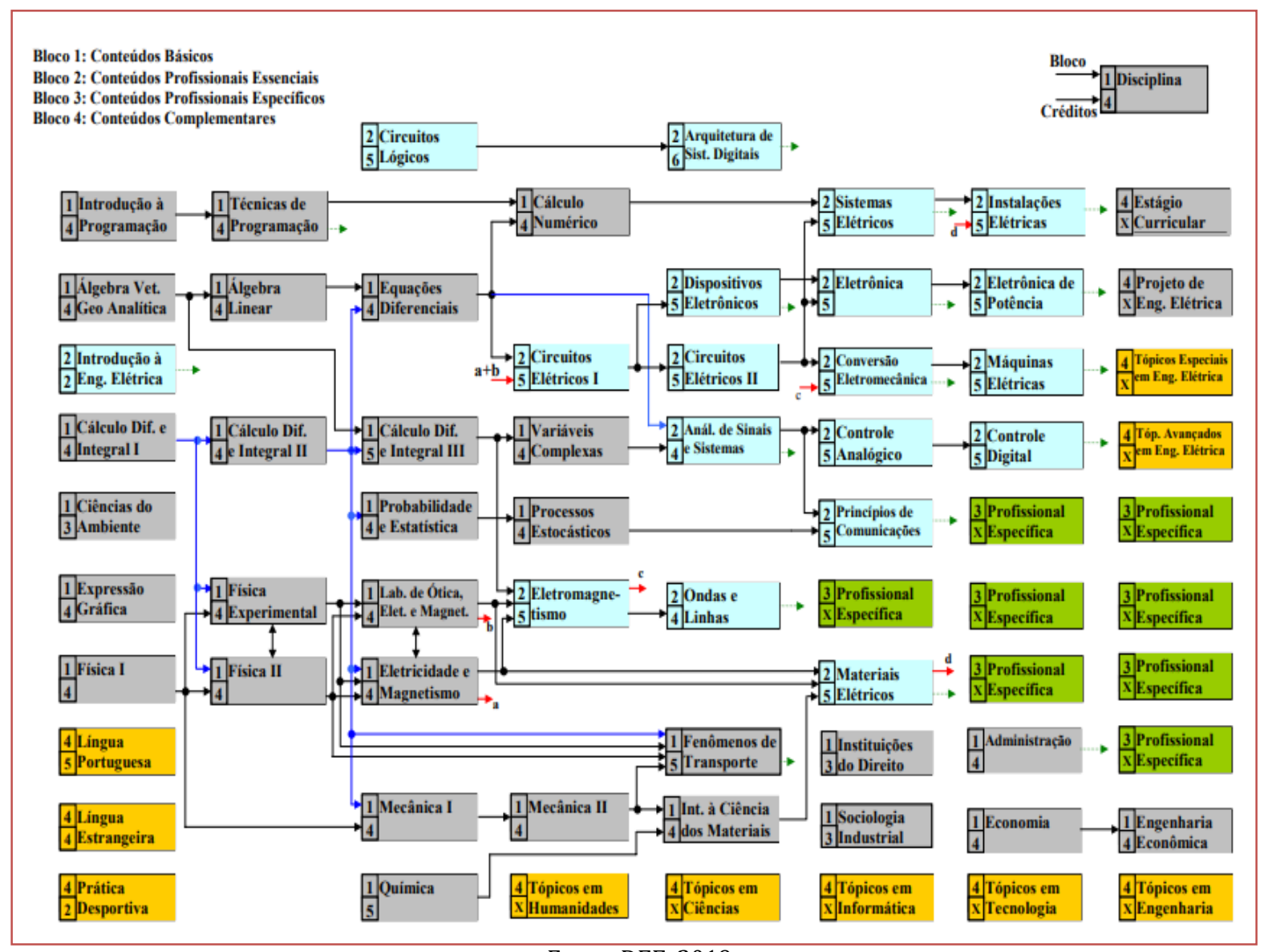

Fonte: DEE, 2019.

O PPC sugere que o estudante receba uma base sólida de cálculo, física, química e programação nos dois primeiros anos de graduação. Nos dois anos subsequentes o curso entranha-se nos conteúdos profissionais, fornecendo uma visão geral sobre todas estas áreas de competências. 0 penúltimo semestre é reservado para o aluno aprofundar os seus estudos em uma das áreas de competência escolhida, podendo ele escolher de uma até todas as quatro áreas fornecidas pela UFCG, no modo de disciplinas presenciais. No último semestre, o aluno faz o seu Trabalho de Conclusão de Curso (TCC) e a disciplina de Estágio.

\section{FORMAÇÃO GENERALISTA DO ENGENHEIRO ELETRICISTA.}

A revolução tecnológica ocorrida na segunda metade do século XX, tida como a terceira revolução industrial, foi marcada pelo surgimento de novas tecnologias, como a eletrônica analógica e digital e os sistemas de telecomunicações avançados, exigindo conhecimentos multidisciplinares e uma forma diferente de processo de trabalho.

Segundo Silveira (2005, p. 13), no passado recente (há 20 anos) exigia-se que estes engenheiros fossem apenas competentes em projetar e gerenciar sistemas de geração, transmissão e distribuição de energia elétrica. Outras características, como liderança ou competência administrativa, eram apenas mencionadas como desejáveis, não como determinantes. 
A partir daí a engenharia elétrica absorveu diversas áreas de atuação e atualmente abrange inúmeras especializações, porém todas interdependentes entre si.

Segundo Cotosck (2007, p. 22), as disciplinas nos cursos de engenharia elétrica são, na maioria das vezes, apresentadas aos alunos de forma dissociada uma das outras. Em oposição a isto está o futuro do aluno de engenharia: as áreas integralizadas, os equipamentos utilizando diferentes tecnologias e profissionais de setores diferentes trocando informações.

Portanto, mesmo havendo uma distribuição da engenharia elétrica em diversas áreas de atuação, todas elas estão interligadas. A formação generalista é de grande importância para que se prepare profissionais diferenciados e com conhecimentos sólidos, uma vez que, o profissional deve estar preparado para enfrentar as adversidades que possam surgir relacionadas ao exercício da função.

Em consonância com os argumentos levantados por este trabalho, o CNE homologou, em 23 de janeiro de 2019, as novas DCNs para os cursos de graduação em engenharia. O objetivo é ajustar as estruturas desses cursos para formação de engenheiros capazes de enfrentar os desafios da Indústria 4.0. A quarta revolução industrial, ou Indústria 4.0, se caracteriza por um conjunto de tecnologias que permitem a fusão do mundo físico, digital e biológico (MDIC, 2019).

As principais mudanças estabelecidas nas novas DCNs são (PATI, 2019) (CNE, 2019):

- Flexibilização curricular: tem como objetivo permitir maior flexibilidade na estruturação dos cursos de Engenharia, facilitando que as instituições de ensino inovem seus modelos de formação.

- Interdisciplinaridade: desde o início do curso, as atividades que promovam a integração e a interdisciplinaridade devem ser realizadas, de modo coerente com o eixo de desenvolvimento curricular, para integrar as dimensões técnicas, científicas, econômicas, sociais, ambientais e éticas.

- Formação por competências: os engenheiros devem ser aptos para resolução de problemas e proposição de soluções de engenharia a partir da análise e compreensão de usuários e do contexto, assim como capacidade de implementar, supervisionar e controlar essas mesmas soluções; devem ter capacidade de conceber, projetar e analisar sistemas, produtos, componentes ou processos; e competências como trabalho em equipe, comunicação, capacidade de aprendizagem e preparo para lidar com situações complexas também estão destacadas; entre outros.

Assim, no período em que ocorre uma revolução tecnológica, é exigido do profissional uma dinâmica que acompanhe o mercado em constante atualização. É imprescindível, portanto, a capacidade adaptativa dos profissionais engenheiros, alcançada mediante uma formação firmada em uma base de conhecimentos sólidos e generalistas.

\section{METODOLOGIA}

É frequente os debates sobre a importância da formação generalista no curso de Engenharia Elétrica da UFCG, alguns defendem a formação generalista e outros defendem a divisão do curso. Portanto, a fim de coletar as expressões e impressões dos egressos do curso, um estudo foi realizado por Filgueiras; Araujo; Oliveira (2018) quantificando suas opiniões sobre o assunto. As opiniões foram coletadas por meio de um questionário criado na plataforma "Google Docs". Para respondê-lo, o egresso deveria acessá-lo por meio do link fornecido na plataforma do Google e identificar-se, fornecendo seu nome, e-mail e ano de formação.

No questionário foi perguntado aos engenheiros: ano de formação; área de formação escolhida para aprofundamento de estudos; em qual setor atua profissionalmente; área de atuação efetiva no trabalho atual; se estão alocados em algum cargo de gestão; e, por fim, se são ou não a favor da formação generalista. Foram obtidas 181 respostas em 17 dias de questionário, que ficou disponível entre os dias 05 de abril de 2018 e 22 de abril de 2018

Entre 1963, ano de fundação do curso, até a realização desse questionário, abril de 2018, 2800 engenheiros eletricistas se formaram na UFCG, sendo que 1050 desses engenheiros são egressos formados a partir de 1999, ano da nova estrutura curricular, com foco na formação generalista e divisão do curso em quatro modalidades. Assim, o total de respostas obtidas, 181, corresponde a uma amostra de 6,5\% do total de toda a vida do curso até 2018 e, referentes aos egressos a partir de 2002, a amostra representa 15\% do egressos graduados. 


\section{RESULTADOS}

No presente trabalho novas análises dos resultados apresentados por Filgueiras; Araujo; Oliveira, (2018) serão estendidas e novos dados serão expostos. Assim, na Figura 2 é mostrado a porcentagem de engenheiros eletricistas por área de formação. A eletrotécnica é a área mais escolhida para aprofundamento de estudos representando $48,60 \%$ dos egressos.

Figura 2 - Áreas de competência escolhidas para aprofundamento dos estudos x Percentual.

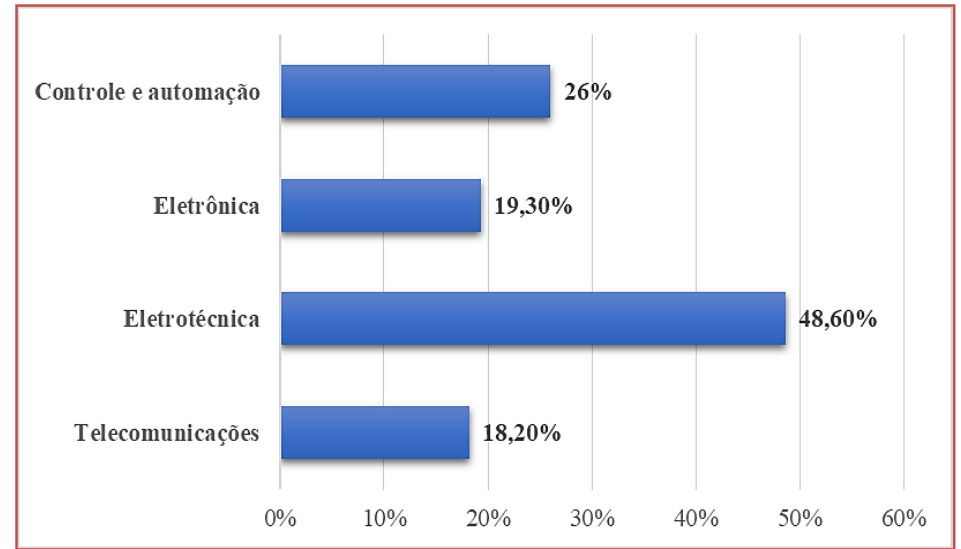

Fonte: FILGUEIRAS; ARAUJO; OLIVEIRA (2018).

Como o aluno pode escolher de uma até todas as quatro áreas fornecidas pela UFCG, analisou-se a quantidade de estudantes que optaram por se aprofundar em mais de uma área de competência. Dos respondentes, foi constatado que $88,4 \%$ dos egressos optaram por se aprofundar em apenas uma das áreas. Aqueles que optaram por se aprofundar em duas áreas totalizam 11,6\%, e nenhum deles optaram por se aprofundar em 3 ou 4 áreas.

Para o caso da escolha de duas competências, avalia-se que existem 6 combinações possíveis. A combinação mais escolhida, representando $33,33 \%$, foi a conciliação entre a eletrotécnica e o controle e automação. As combinações entre eletrônica e telecomunicações e entre eletrônica e controle e automação representam 23,81\%, cada uma. As outras três combinações possíveis, representaram, juntas, 19,05\%.

No que diz respeito à atuação profissional, foi levantado o questionamento sobre quais área de competências são efetivamente utilizadas para o exercício da sua função. Da Figura 3 é concluído que apenas $29,83 \%$ dos engenheiros utilizam exatamente a sua área de competência. Todo o restante utiliza conhecimentos que vão além da sua área de aprofundamento de estudos.

Figura 3 - Conhecimentos utilizados para a atuação profissional.

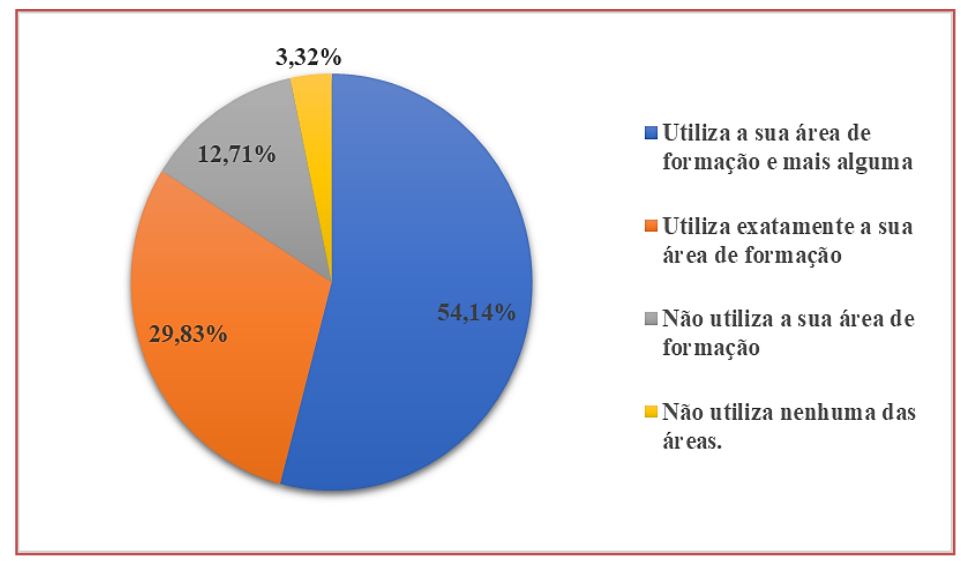

Fonte: FILGUEIRAS; ARAUJO; OLIVEIRA (2018). 
Além disso, foi verificado que a área de competência mais utilizada no cenário do mercado de trabalho atual é a eletrotécnica, seguida do controle e automação e da eletrônica, como pode ser visto na Figura 4.

Figura 4 - Áreas de competência efetivamente utilizadas no exercício da função x Percentual.

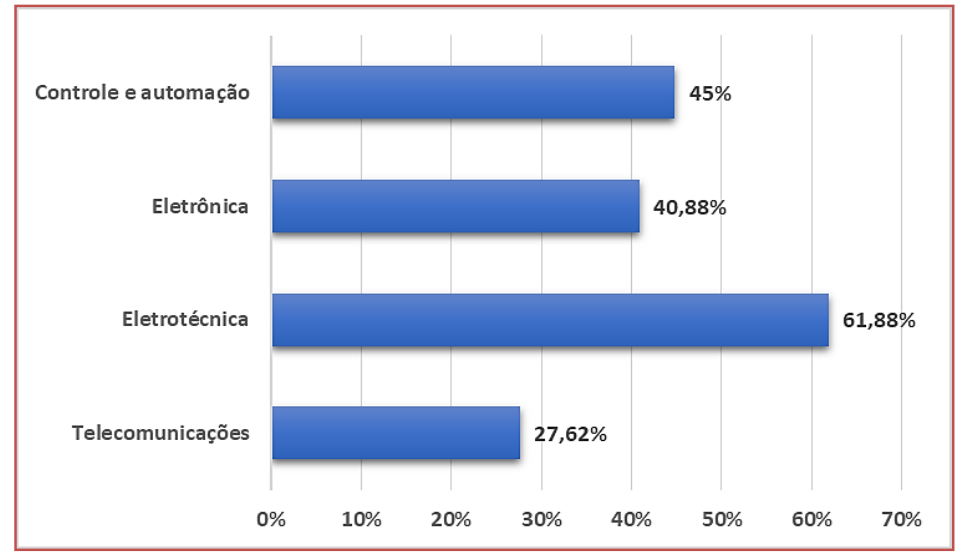

Fonte: Autoria Própria, 2019.

Finalizando a análise da atuação profissional desses engenheiros no cenário atual, foi perguntado em qual setor eles estão trabalhando. Chama a atenção que os engenheiros eletricistas egressos da UFCG, que responderam o questionário, possui um perfil empreendedor pouco desenvolvido, representando apenas $4,42 \%$ do total, como observado na Figura 5. Os engenheiros atuantes nas indústrias e comércios do setor privado somam $40,88 \%$ do total, enquanto que os atuantes no setor público representam $14,92 \%$. Os optantes pela carreira acadêmica totalizam $34,81 \%$. Os desempregados foram representados por apenas $4,97 \%$ do total.

Figura 5 - Setores de atuação profissional.

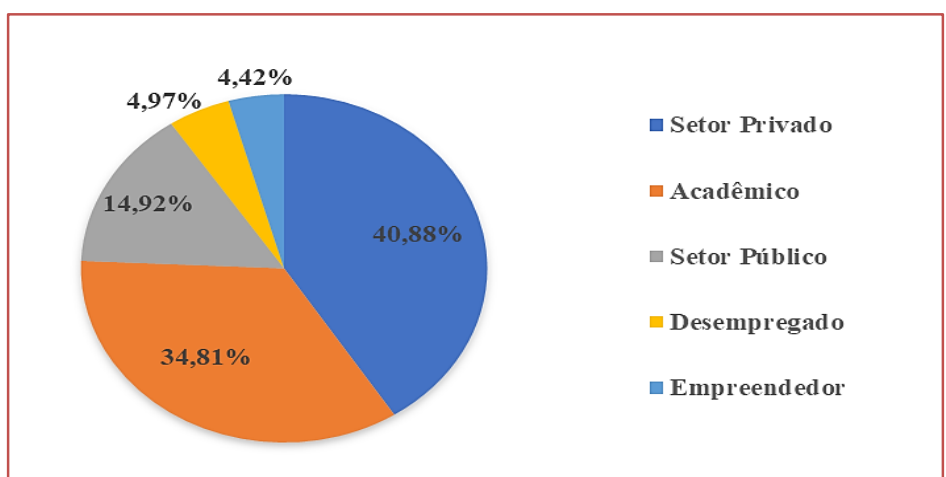

Fonte: Autoria Própria, 2019.

Quanto às opiniões sobre o tipo de formação, foi perguntado ao engenheiro eletricista, se ele considera importante a formação generalista proporcionada a ele, pela UFCG, para a sua atuação profissional. As respostas afirmativas somaram $91,71 \%$ do total. É notado que, alguns dos que não são a favor da formação generalista atuam em uma área diferente daquela em que se formou.

Ao fim das perguntas, foi reservado no questionário, um espaço de sugestões e comentários. Nesse espaço é bastante expressiva a quantidade de comentários afirmando que a formação generalista forneceu uma flexibilidade profissional considerável e uma capacidade de abstração de problemas acima da média. É significante, também, a quantidade de comentários que sugerem que o PPC passe a contemplar disciplinas de gestão e empreendedorismo. Alguns comentários são expostos a seguir: 
"A formação generalista oferecida pelo curso de graduação em engenharia elétrica da UFCG possibilita que seu egresso atue em diferentes áreas da elétrica, consiga desenvolver trabalhos multidisciplinares e tenha maior mobilidade em função de sazonalidades do setor".

"A grade curricular que cursei foi muito bem formulada. A base sólida do curso generalista agrega flexibilidade enquanto que as disciplinas das áreas trazem alguma especificidade. [...] A formação generalista é uma vantagem para o profissional, visto que o mercado de trabalho frequentemente exige que este possua capacidade de adaptação".

"Sem sombra de dúvida, a formação generalista foi um grande facilitador na minha migração entre áreas afins. Eu me graduei em Eletrotécnica e atuei com Previsão de Demanda para Sistemas de Distribuição e Alocação de Reativos. Migrei para Desenvolvimento de Sistemas Embarcados Automotivos, e atualmente trabalho com Sistemas Embarcados e Engenharia de Software em Projetos de Automação Industrial dos mais diversos".

\section{CONSIDERAÇÕES FINAIS}

Neste trabalho foram apresentadas algumas das capacidades e atribuições dos profissionais engenheiros eletricistas. Foi exposta também, a necessidade desses profissionais possuírem uma habilidade adaptativa considerável para enfrentar as sazonalidades da atuação profissional, além de visão crítica, criativa e inovadora.

Uma pesquisa foi realizada com os engenheiros eletricistas egressos da UFCG, cujo objetivo é coletar as expressões e impressões desses profissionais em relação a esse tipo de formação. A pesquisa expõe que grande parte dos engenheiros eletricistas utilizam, profissionalmente, conhecimentos que vão além da sua formação e, também, que a maioria considera a formação generalista importante para a sua atuação profissional.

Comparando o atual PCC da UFCG às mudanças que as novas DCNs trazem, é visto que várias demandas já são atendidas. É bem verdade, porém, que algumas atualizações do curso são necessárias, como a inclusão de disciplinas de gestão e empreendedorismo. Essas atualizações, no entanto, devem preservar a característica de uma formação básica, geral e humanista sempre associada a uma formação profissional sólida e generalista.

\section{REFERÊNCIAS}

[1] ABENGE. Diretrizes Curriculares para os Cursos de Engenharia. 1998.

[2] CGEE. Projeto Pedagógico do Curso de Engenharia Elétrica. 2004. Disponível em: <https://sites.google.com/a/dee.ufcg.edu.br/cgee/curriculo>. Acesso em: 10 abr. 2019.

[3] CNE. Diretrizes Curriculares Nacionais do Curso de Graduação em Engenharia, Distrito Federal, Brasil, 2019. p. 1-21.

[4] COCIAN, Luis Fernando Espinosa. Engenharia: Uma Breve Introdução. 1o ed, Porto Alegre: Bookman, 2016.

[5] COTOSCK, Kelly Regina. Proteção de sistemas elétricos: uma abordagem técnico pedagógica. 2007. 109 f. Dissertação (Mestrado) - Universidade Federal de Minas Gerais, Belo Horizonte, 2007.

[6] DEE. Engenharia Elétrica: perfil do curso/área de atuação. 2019. Disponível em: <https://portal.ufcg.edu.br/graduacao/cursos-graduacao/296-engenharia-eletrica.html>. Acesso em: 10 abr. 2019.

[7] FILGUEIRAS, L. V. O.; ARAUJO, D. N.; OLIVEIRA, T. M. Formação e competência do engenheiro eletricista análise sistêmica/Education and competence of the electrical engineer - systematic analysis. Brazilian Applied Science Review, v. 3, n. 1, p. 491-502, 2018.

[8] MDIC. Ministério da Indústria, Comércio Exterior e Serviços. Agenda brasileira para a Indústria 4.0. 2019. Disponível em: <http://www.industria40.gov.br/>. Acesso em: 5 maio. 2019.

[9] MENDES, Gloriquele; BRAGA, Marinilson. UFCG completa 15 anos de criação. 2017. Disponível em: <http://cfp.ufcg.edu.br/portal/index.php/noticias-do-centro/124-ufcg-completa-15-anos-de-criacao>. Acesso em: 10 abr. 2019.

[10] PATI, Camila. Cursos de engenharia vão mudar com novas diretrizes publicadas pelo MEC. 2019. Disponível em: <https://exame.abril.com.br/carreira/cursos-de-engenharia-vao-mudar-com-novas-diretrizes-publicadas-pelomec/>. Acesso em: 6 maio. 2019. 
[11] SALETE, Maria et al. Atraindo alunos para o curso de engenharia de computação através da troca de experiências. Congresso Brasileiro de Ensino de Engenharia. Belém. 2012.

[12] SILVEIRA, Marcos Azevedo da. A formação do engenheiro inovador: uma visão internacional. estrutura das revoluções cientificas. Rio de Janeiro: PUC-Rio, Sistema Maxwell, 2005. 


\section{Capítulo 19}

Prepare melhor o estudante para um futuro incerto: Incorpore Soft Skills no ensino contábil

\section{José Dutra de Oliveira Neto}

Luciano Bastos de Carvalho

Resumo: Organizações internacionais e empresas destacam a necessidade do desenvolvimento de soft skills nas instituições de ensino. As habilidades sociais, somadas às técnicas e teorias comumente ensinadas, completam o desenvolvimento dos alunos. Os estudos apontam as ferramentas de metodologias ativas como solução para preencher essa necessidade. Contudo, as pesquisas negligenciam o comportamento do docente em sala de aula durante a aplicação da metodologia ativa. 0 foco dessas pesquisas consiste na metodologia ativa em si. Assim, a presente pesquisa objetiva entender como o comportamento do professor influencia o desenvolvimento de soft skills nos discentes. As soft skills em análise consistem no modelo de aprendizado integral do ensino contábil, são elas: resolução de problemas, pensamento crítico, colaboração e comunicação. Essas habilidades sociais serão verificadas em um curso de contabilidade que utilizada ferramenta de ensino a distância moodle e que contém aulas presenciais em uma universidade pública. A disciplina é dividida em duas classes de 36 alunos, diferenciadas pelo comportamento do professor. Ambas as classes têm o conteúdo da disciplina apresentado conforme a metodologia problem-based learning. Porém, em uma classe o docente expõe a matéria detalhadamente e na outra incentiva os alunos a buscarem o conhecimento. 0 final da disciplina ocorrerá por meio de uma apresentação de resolução de um estudo de caso único por ambas as classes a um público misto de avaliadores externos e internos. Esses avaliadores analisarão as soft skills destacadas. Espera-se que a classe que necessitou buscar o próprio conhecimento para a resolução dos casos tenha um maior desenvolvimento das soft skills. A outra classe tenderá a ter um aprendizado mais rápido nas hard skills. Contudo, no final do processo de ensino há a expectativa de ambas salas possuírem o mesmo nível de hard skills e o comportamento do docente influenciar especificamente a formação das

Soft skills nos alunos.

Palavras-chave: SOFT SKILLS; EDUCAÇÃO; CONTABILIDADE; METODOLOGIAS ATIVAS 


\section{INTRODUÇÃO}

As entidades internacionais têm demonstrado que os profissionais graduados no ensino superior não possuem as habilidades sociais necessárias para atuar no mundo corporativo. 0 International Education Standard (IES) 3, publicado pela International Accounting Standars Board em 2015, aborda as habilidades profissionais exigentes para o profissional contábil como: (i) as intelectuais, (ii) intepessoais e de comunicação e (iii) pessoal e organizacional. Esses padrões educacionais visam atender as demandas do mercado, que procuram habilidades além das técnicas e conhecimentos teóricos (hard skills), buscam profissionais com suas soft skills desenvolvidas.

Pesquisa realizada com empresas listadas na Fortune 500 demonstra que tais empresas almejam profissionais com atitudes positivas, respeito, confinaça, iniciativa, trabalho em equipe e comunicação (JONES, BALDI, PHILLIPS \& WAIKAR, 2016). Com enfoque na área contábil, estudo realizado na Nova Zelândia aponta que os cursos na área de négocio necessitam adicinar o desenvolvimento de soft skills em sua grade curricular (DE VILLIERS, 2011). Os soft skills auxiliam o profissional em negociações e trabalhos em grupos existentes em uma rotina empresarial (DE VILLIERS, 2011; RITTER et al., 2018). Assim, para o desenvolvimento das soft skills de modo a suprir a demanda mercadológica, os professores são incentivadas a utilizar técnicas de aprendizado ativo em suas aulas (NEALY, 2012).

O estudo de metodologias ativas busca desenvolver as soft skills nos alunos por meio de ações préprogramadas. Entre as metodologias utilizadas se destaca o método Problem-Based Learning (PBL). Tal método consiste em proporcionar uma atividade prática aos alunos por meio de um estudo de caso (BARROWS, 1996; NEALY, 2012). As pesquisas sobre a aplicação do PBL demonstram o desenvolvimento nos alunos do trabalho em equipe, gerenciamento de conflitos, tomadas de decisão e habilidades de comunicação. Contudo, essas pesquisas estudam somente o comportamento dos alunos, não é avaliado o comportamento do docente que, segundo Barrows (1996), pode influenciar o desenvolvimento dos soft skils. 0 comportamento do professor é apresentado como uma das fases necessárias para a formação integral de um aluno, com seu desenvolvimento social e técnico (Gomes, 2018). Tal fase consiste na presença de ensino contida na Modelo de Aprendizgem Integral (MAI) desenvolvido por Gomes (2018).

Diante do exposto, a presente pequisa objetiva entender como o comportamento do professor influencia o desenvolvimento das Soft Skills de seus alunos. Para isso, desenvolveu-se um framework para a aplicação da metodologia PBL, baseado no MAI, em uma turma de graduação em Ciências Contábeis de uma universidade pública do estado de São Paulo. O PBL aplicado busca desenvolver as soft skills apresentadas no MAI: pensamento crítico, solucação de problemas, colaboração e comunicação. A seguir é discutido o que a literatura apresenta sobre essas soft skills e como o PBL atua em seu desenvolvimento. Posteriormente, discute-se a metodologia emprega nessa pesquisa, descrevendo os passos do PBL aplicados nas turmas alvo desse estudo.

\section{REVISÃO TEÓRICA}

A literatura demonstra que as empresas estão em busca de profissionais com as denomiadas soft skills, como habilidades complementares as já exigidas hard skills. Entrevistas realizadas com empresas americanas demonstraram que os recrutadores almejam profissionais com as seguintes hablidade: atitudes positivas, respeito a outros, confiança, iniciativa, responsabilidade, trabalho em equipe e comunicação (JONES et al., 2016). Tal pesquisa complementa estudo realizado por Anthony e Garner (2016) que aponta que as faculdades objetivam em transmitir habilidades para preencher a demandas técnicas da força de trabalho do mercado, chamadas de hard skills, porém as soft skills não são trabalhadas. Assim, para melhor entendimento da importância das soft skills e de sua ligação com a educação elas são detalhadas a seguir.

\section{1- ESTUDOS SOBRE SOFT SKILLS}

Os soft skills são habilidades importantes em qualquer ambiente de trabalho (MATTESON; ANDERSON; BOYDEN, 2016). Tais habilidades moldam o comportamento dos trabalhadores, contudo, segundo Matteson, Anderson e Boyden (2016) não há definições específicas sobre as particularidades das soft skills individuais.

Para o entendimento das soft skills, primeiramente os autores definem habilidade como uma ação ocasionada pelo acesso a certo conhecimento. Assim, as soft skills consistem em ações não promovidas por fatores de conhecimentos técnicos, mas de conhecimentos comportamentais interpessoal e 
intrapessoal (MATTESON; ANDERSON; BOYDEN, 2016). Estudo realizado especificamente na área contábil por Tan e Laswad (2018) na Austrália e Nova Zelândia demonstrou que o trabalho colaborativo com os colegas, atitudes positivas, trabalho em equipe e comunicação estão entre as principais soft skills almejadas pelo mercado a este profissional. Os estudos sobre o desenvolvimento dessas habilidades sociais apresentam a necessidade da vivência por parte do aluno de situações reais ou idealizadas para a consolidação do conhecimento teórico adquirido. Uma teoria que rege esses estudos é chamada de Teoria da Aprendizagem Experiencial.

A Teoria da Aprendizagem Experiencial elabora por Dewey (1981) consiste na experiência como sinônimo da educação. 0 saber é caracterizado pelas vivências dos indivíduos. Assim, em sua obra o autor apresenta que a educação e a experiência devem ser vistas como sinônimos e possui seu início no nascimento de cada indivíduo. Portanto, a medida em que o indivíduo passa por experiências em sua vida ele se molda conscientimente, formando hábitos e despertando sentimentos e emoções.

Dewey (1981) destaca que a experiência constroi o pensamento do indivídio e sua teoria auxilia no desenvolvimento de aborgens construtivista na educação. A abordagem construtivista auxiliou o desenvolvimento das competências para a formação contábil integral desenvolvido por Gomes (2018). Nesse modelo de formação os alunos são incentivados a interagir livrimente para manifestação de ideias, expressões e troca de experiência entre si. Esse arranjo objetiva desenvolver as seguintes soft skills: resolução de problemas, pensamento crítico, colaboração e comunicação. Essas soft skills são apresentadas pela autora após uma revisão realizada na literatura e análise das soft skills necessárias para a formação integral de um aluno no curso de graduação em ciências contábeis. Portanto, como a presente pesquisa se baseia nesse modelo e também é aplicado em uma disciplina do curso de ciências contábeis, essas soft skills foram as avaliadas nesse estudo.

A Tabela 1 demonstra os soft skills a serem observadas, os conceitos utilizados e a literatura de embasamento teórico de forma a resumir os conceitos apresentados e que são utilizados na presente pesquisa.

TABELA 1 - DETALHES DAS SOFT SKILLS UTILIZADAS NA PESQUISA

\begin{tabular}{|l|l|l|}
\multicolumn{1}{|c|}{ Soft Skills } & \multicolumn{2}{c|}{ Conceitos } \\
\hline $\begin{array}{l}\text { Resolução de } \\
\text { Problemas }\end{array}$ & $\begin{array}{l}\text { Descoberta do problema a ser } \\
\text { resolvido. Análise de fatos e } \\
\text { circustâncias do objeto em estudo. }\end{array}$ & $\begin{array}{l}\text { COETZZ et al., 2012 - OSCMANI; HIDI; WEERAKKODY, } \\
\text { 2018 - DAOUK; BAHOUS; BACHA, 2016 - FAUST; } \\
\text { PAULSON, 1998 - BARROS; BITTENCOURT, } 2019 .\end{array}$ \\
\hline Pensamento Crítico & $\begin{array}{l}\text { Pbservação e avaliação de sistemas } \\
\text { complexos. Conclusões justificáveis a } \\
\text { questões não facilmente respondidas. }\end{array}$ & $\begin{array}{l}\text { COETZZ et al., 2012 - MOHAMED; LASHINE, 2003 - COBO, } \\
\text { 2013 - RITTER et al., 2008 - FAUST; PAULSON, 1998. }\end{array}$ \\
\hline \multirow{2}{*}{ Colaboração } & $\begin{array}{l}\text { União de diferentes indivíduos em } \\
\text { busca de um objetivo comum. } \\
\text { Compartilhamento de informações. }\end{array}$ & $\begin{array}{l}\text { NGANG; YUNUS; HASHIM, 2015 - MESSNER, 2010 - TAN; } \\
\text { LASWAD, 2018 - EUROPEAN COMMISSION, } 2010 \text { - } \\
\text { DAOUK; BAHOUS; BACHA, 2016. }\end{array}$ \\
\hline \multirow{2}{*}{ Comunicação } & $\begin{array}{l}\text { Transmissão de mensagem de forma } \\
\text { clara e com confiança. Escutar e } \\
\text { passar informação apropriadamente. }\end{array}$ & $\begin{array}{l}\text { NGANG; YUNUS; HASHIM, 2015 - YOKE; NGANG, 2015 - } \\
\text { MESSENER, 2010; - JACKLING; DE LANGE, 2009 - KEEVY, }\end{array}$ \\
\hline
\end{tabular}

Fonte: GOMES (2018)

\section{METODOLOGIA}

As soft skills estão em devolvimento na disciplina de informática aplicada do curso de graduação em ciências contábeis de uma universidade pública do estado de São Paulo. A disciplina é ofertada como parte curricular obrigatória no primeiro semestre de 2019 do curso em questão. Um total de 72 alunos foram matrículados. Os alunos foram divididos em duas classes, ambas com 36 alunos.

A disciplina foi preparada para atuação em um ambiente virual. Embora a disciplina seja ofertada presencialmente, a plataforma moodle é utilizada para a distribuição de todo material utilizado pelos alunos para a realização das atividades. Nessa plataforma, desenvolvida para cada uma das turmas, são disponibilizados vídeos educativos sobre cinco fases do desenvolvimento de cada etapa do PBL, realizadas em dias de aulas distintos: (i) definir problema e planejar solução, (ii) treinamento de ferrementas do Excel, (iii) discutir a solução, (iv) comunicar os resultados e (v) ética. A segur apresenta- se o trabalho em desenvolvimento em cada etapa em ambas turmas e seus respectivos objetivos.

A etapa inicial de definição de problema e planejamento de sua solução se inicia com a atuação individual 
do aluno na leitura e proposta de solução do problema exposto no moodle a ser submetido ao ambiente virtual. Para a postagem final, referente a fase individual do primeiro dia, o aluno necessita apresentar as definições de conceitos chaves para a resolução do problema. Esses conceitos, depois são discutidos em grupos para alinhamento e preparação de uma proposta em comum. Essas atividades se resumuem nas buscas de conceitos ainda não conhecidos pelos alunos e na solução do problema em si. 0 resultado dessas atividades resumem a finalização desse primeiro dia de atividades. As atividades realizadas por cada membro da equipe são disponizadas no fórum. Os conceitos levantados indivualmente, devido as atividades de cada aluno nos grupos, são disponibilizados no moodle via apresentação eletrônica ou vídeo com link ao canal online "YouTube.com". O canal YouTube é utilizado de modo a servir como incentivador aos alunos, pois a disponibilização online de um material realizado pelos mesmos tendem a forçá-los a produzir um melhor conteúdo se comparado a um vídeo disponível somente ao professor. Os conceitos elecandos individualmente, que formam o conceito teórico para a solução do problema e grupo, são utilizados nos próximos dias de trabalho no estudo de caso apresentado.

A solução teórica proposta pelos grupos, posteriormente, é aplicada na ferramente de tecnologia Excel. Nesse dia os alunos aprendem como utilizar a planilha eletrônica, aplicam os conhecimentos em casos didáticos e são incentivados a auxiliarem colegas com dificuldade. Nesse dia é incentivando o assessoramento entre os alunos do conteúdo prático apresentado pelo professor.

O terceiro dia é dedicado para a discussão da solução do problema apresentado inicialmente com a união dos conceitos teóricos levantados no início da atividade e com a prática da utilização da ferramenta de tecnologia. A discussão em grupo resulta em um rascunho de um relatório da solução realizada em sala de aula. Os alunos devem utilizar o conhecimento adquirido nos dois primeiros dias para resolver o estudo de caso.

Os resultados discutidos pelos grupos são comunicados no quarto dia de atividade. Antes da aula um integrante do grupo disponibiliza no moodle da disciplina um arquivo com os slides a serem apresentados no dia. Todos os integrantes do grupo necessitam de postar no YouTube uma narração sobre o conteúdo dos slides. A atividade éfinalizada com a apresentação final do grupo em sala de aula.

A grande diferenciaça nas duas turmas consiste no comportamento no professor. Na classe A, o professor apenas informava que as informações estão no ambiente virtual da disciplina. Assim, os alunos têm que descobrir por conta própria o problema presente no estudo de caso no dia um e qual função no Excel pode auxiliá-los a resolver tal situação. Por outro lado, o professor auxilia a classeB a identificar o problema existente no estudo de caso no dia um e informa a classe B qual função do excel deve ser utilizada para os auxiliar a resolver o problema apresentado. A intenção dessa diferenciação foi em criar um comportamento diferenciado do professor na aplicação do PBL, e assim verificar se somente modificando esse fator o resultado da metodologia PBL se distingue entre as turmas.

Para avaliar como o PBL desenvolveu as soft skills dos alunos, serão convidadas pessoas que atuam no mercado e pesquisadores da área de negócios para avaliarem o estudo de caso final dos grupos. Esse estudo de caso será entregue igualmente às duas turmas. Porém, dessa vez, o professor não explicará o problema nem apresentará a função em excel para sua resolução para a classe B. Assim, as duas classes tiveram que detectar o problema apresentado no estudo de caso e o resolver de forma independente. A apresentação final desse estudo de caso será realizada para os avaliadores. Os avaliadores externos, convidados, e internos, professores da disciplina, anotarão livrimente durante a apresentação, alternada aleatoriamente entre ambas as turmas, os pontos positivos e negativos de cada apresentação. A única solicitação será para observarem os pontos referentes a comunicação, engajamento e criatividade dos grupos. Essas três características serão alinhadas entre as soft skills pesquisadas, conforme a descrição de cada avaliador.

\section{RESULTADOS ESPERADOS}

Espera-se que as hard skills e soft skills apresentem diferentes evoluções nos alunos das Classes A e B. A Classe A tende a possuir suas Soft Skills mais desenvolvidas, porém a Classe B tende a ter uma maior progresso nas Hard Skills em um primeiro momento.

Como a Classe A deverá buscar o conhecimento de forma própria, a busca de conhecimento individualizada e, posteriormente, compartilhada entre os alunos tende a gerar maiores atritos entre os discentes. Isso devido a não ser apresentada uma possível solução pelo professor previamente. Assim, cada aluno poderá chegar a um possível resultado e os alunos deverão convencer, ouvir e colaborar entre si para amontagem de uma única solução. Porém, a não apresentação pelo docente da técnica e teoria a ser 
utilizada para resolver o caso pode prejudicar o desenvolvimento das hard skills dos alunos dessa classe. As hard skills serão desenvolvidas pelos próprios discentes até o final de cada caso.

A Classe B, por sua vez, já terá a teoria e técnica apresentada pelo professor no início de cada estudo de caso. Isso tende a facilitar a absorção de conhecimentos necessários para a solução do estudo de caso, uma vez que o docente explicará e demonstrará o material que os alunos deverão conhecer para o desenvolvimento da atividade. Desse modo, a hard skill será exposta claramente a Classe B. Contudo, devido a falta de necessidade de buscar conhecimentos e da já definição da teoria a ser utilizada, as soft skills podem ter seu desenvolvimento prejudicado. Tal fato pode ocorrer devido a existência de poucos conflitos e ideias divergentes na Classe B, que partirá do ponto já explicado pelo professor, se comparada a Classe A, que se baseará na busca de teorias e técnicas pelos próprios discentes.

Portanto, os resultados dessa pesquisa demonstrarão como o comportamento do professor afeta o desenvolvimento não somente das soft skills, como também das hard skills. Porém, como a intenção do processo de ensino é que tanto a Classe A e Classe B tenham o mesmo desenvolvimento das hard skills no final do processo educacional, o diferencial de como o docente atua em sala de aula tende a impactar principalmente nas soft skills dos discentes.

\section{CONSIDERAÇÕES FINAIS}

As soft skills são necessárias para o convívio dos indivíduos em ambientes sociais, desde familiares a profissionais. Assim, a pesquisa em desenvolvimento implicará em uma análise sobre o papel da escola e dos professores na formação do aluno para sua vida social de forma geral.

0 resultado da pesquisa apresentará a influência comportamento do docente no processo de transmissão de conhecimentos a seus alunos. Contudo, o conhecimento não se limita as hard skills. 0 aluno deve ser fomado com aptão a resolver problemas, pensar de forma crítica, se comunicar e a colaborar com os diversos tipos de personalidades e nas diversas situações existentes na vida fora do ambiente escolar.

Além desse aprimoramento pessoal, a escola que formar um aluno com soft skills diferenciadas, respondendo a demandas de mercado, tende a ter seus alunos como alvos preferenciais de contratação das empresas. Desse modo, caso uma instituição de ensino demonstre ao mercado que forma profissionais com habilidades que ele exige, esses alunos tendem a ter uma ascensão profissional acelerada e a entidade de ensino tende a ser valorizada no ambiente educacional.

Portanto, o desenvolvimento de soft skills não consiste somente em utilizar uma metodologia de ensino que visa a seu desenvolvimento. 0 comportamento diferenciado do docente implicará em um progresso maior nas soft skills dos discente ou não. Por fim, conclui-se que o comportamento didático, não somente a técnica metodológica, é de suma importância para o desenvolvimento de soft skills nos alunos e tais habilidades influenciarião sua vida social pós instituição de ensino.

\section{REFERÊNCIAS}

[1] Anthony, S.; Garner, B. Teaching Soft Skills to Business Students. Business and Professional Communication Quarterly, v. 79, n. 3, p. 360-370, 2016.

[2] Barros, F. L. F.; Bittencourt, R. A. Evaluating the Influence of PBL on the Development of Soft Skills in a Computer Engineering Undergraduate Program. 2018 IEEE Frontiers in Education Conference (FIE), p. 1-9, 2019.

[3] Barrows. Problem-based learning in medicine and beyond: A brief overview. New Directions for Teaching and Learning, v. 68, n. 68, p. 3-12, 1996.

[4] Cobo, C. Skills for innovation: Envisioning an education that prepares for the changing world. Curriculum Journal, v. 24, n. 1, p. 67-85, 2013.

[5] Coetzee, M. et al. Developing student graduateness and employability. [s.l: s.n.].

[6] Daouk, Z.; Bahous, R.; Bacha, N. N. Perceptions on the effectiveness of active learning strategies. Journal of Applied Research in Higher Education, v. 8, n. 3, p. 360-375, 2016.

[7] De Villiers, R. The incorporation of soft skills into accounting curricula: preparing accounting graduates for their unpredictable futures. Meditari Accountancy Research, v. 18, n. 2, p. 1-22, 2011.

[8] European Commission. Eurobarometer on graduate Employers value teamwork, communication and language skills employability : adaptability ,. n. December, 2010. 
[9] Faust, J. L.; Paulson, D. R. Active Learning: Cooperation in the College Classroom. v. 9, p. 140, 1998.

[10] Gomes, G. de S. Modelo de Aprendizagem Integral (MAI): um novo modelo para o ensino de contabilidade. 2018.

[11] Jackling, B.; de Lange, P. Do accounting graduates' skills meet the expectations of employers? a matter of convergence or divergence. Accounting Education, v. 18, n. 4-5, p. 369-385, 2009.

[12] Jones, M. et al. the Hard Truth About Soft Skills: What Recruiters Look for in Business Graduates. College Student Journal, v. 50, n. 3, p. 422-428, 2016.

[13] Keevy, M. Using case studies to transfer pervasive skills : Some South African evidence Abstract. 2016.

[14] Matteson, M. L.; Anderson, L.; Boyden, C. "Soft Skills": A Phrase in Search of Meaning. portal: Libraries and the Academy, v. 16, n. 1, p. 71-88, 2016.

[15] Messner, M. Contemporary Issues in Accounting. [s.l.] Springer International Publishing, 2010. v. 19

[16] Mohamed, E. K. A.; Lashine, S. H. Accounting Knowledge and Skills and the Challenges of A Global Business Environment. 2003.

[17] Nealy, C. Integrating Soft Skills Through Active Learning In The Management Classroom. Journal of College Teaching \& Learning (TLC), v. 2, n. 4, p. 2-7, 2012.

[18] Ngang, T. K.; Yunus, H. M.; Hashim, N. H. Soft Skills Integration in Teaching Professional Training: Novice Teachers' Perspectives. Procedia - Social and Behavioral Sciences, v. 186, p. 835-840, 2015.

[19] Osmani, M.; Hindi, N. M.; Weerakkody, V. Developing Employability Skills in Information System Graduates. International Journal of Information and Communication Technology Education, v. 14, n. 2, p. 17-29, 2018.

[20] Ritter, B. A. et al. Designing Management Curriculum for Workplace Readiness: Developing Students' Soft Skills. Journal of Management Education, v. 42, n. 1, p. 80-103, 2018.

[21] Tan, L. M.; Laswad, F. Professional skills required of accountants: what do job advertisements tell us? Accounting Education, v. 27, n. 4, p. 403-432, 2018.

[22] Yoke, Tan Cheng; Ngang, T. K. a Study on Soft Skill Development Among Final Year Diploma in Business Studies Students. Malaysian Online Journal of Educational Management (Mojem), v. 4, n. 1, p. 64-85, 2015. 


\title{
Capítulo 20
}

Escritório habitar: Elaboração de projetos técnicos em engenharia destinado à população de baixa renda através da extensão universitária

\author{
Ana Lidia Alencar Vasconcelos \\ Ana Verônica Gonçalves Borges \\ Edenia Nascimento Barros \\ Engels Zalmom de Carvalho Lacerda \\ Erwin Ulises Lopez Palechor \\ Marcelo de Sousa Alves \\ Simon Sabino Jacó do Nascimento
}

Resumo: 0 déficit de moradia no Brasil vem crescendo no decorrer dos últimos anos com números alarmantes, o que colabora com surgimento e agravamento das autoconstruções, que são instrumentos empíricos criados pela própria população no desejo de adquirirem informalmente a construção de suas moradias, sendo essa prática construtiva um mecanismo perigoso devido as seguintes situações: ausência de projetos, a execução das residências não são realizadas de acordo com as normas técnicas e também não possuem planejamento e acompanhamento de profissionais capacitados da construção civil. Sendo assim, com a finalidade de colaborar com o acesso a moradia para essas famílias que são vítimas do déficit habitacional, que possivelmente optariam pela autoconstrução das suas residências, foi criado o Escritório Habitar, através do programa de extensão vinculado a Pró-Reitoria de Extensão - PROEX da Universidade Federal do Cariri - UFCA. O Habitar atua no desenvolvimento e execução de projetos técnicos em engenharia destinado à população em condições de vulnerabilidade socioeconômica na região do cariri cearense. Os procedimentos adotados foram subsidiados por métodos de natureza descritiva e qualitativa-documental. Pode-se constatar que o Escritório Habitar levou aos seus beneficiários a oportunidade de construir de forma segura e econômica, priorizando o bem-estar dessas famílias. Além disso, contribuiu com o enriquecimento acadêmico dos estudantes que atuam na ação, através da autoaprendizagem e maior domínio dos softwares utilizados em projetos construtivos, colaborando com o desenvolvimento de experiência do cotidiano da futura profissão.

Palavras-chave: extensão universitária; habitação; autoconstrução; autoaprendizagem. 


\section{INTRODUÇÃO}

No Brasil, milhões de famílias estão excluídas do acesso a moradia digna. De acordo com a Fundação Getúlio Vargas (2018), o déficit habitacional total no Brasil foi estimado em 7,77 milhões de unidades. Este mesmo estudo realizou uma projeção da demanda de moradias até o ano de 2027 e a metodologia adotada apontou uma necessidade de 9,049 milhões de unidades, correspondente a demanda incremental (por novas habitações) total no período, o que equivale a um pouco mais de 900 mil unidades por ano. No estado do Ceará, local da implantação do Projeto Habitar, a questão da habitação é reflexo da realidade brasileira, se caracterizando pela existência de déficit habitacional em níveis expressivos.

Os dados acima nos mostram que o Brasil é um país que está bem longe de atingir o direito de moradia diga e segura, que é um dos direitos humanos garantidos pela legislação internacional e também pela Constituição brasileira. Seu reconhecimento se deu em 1948 através da Declaração Universal dos Direitos Humanos (ONU, 1948), como parte integrante de um padrão de vida adequado. Em 1966, através do Pacto Internacional de Direitos Econômicos, Sociais e Culturais (ONU, 1966), tornou-se um direito humano universal, aceito e aplicável em todas as partes do mundo como fundamental para a vida. Na Constituição brasileira, este direito está reconhecido no seu artigo 6ํㅜㄹ juntamente com a saúde, a educação e a justiça.

Uma das grandes causas desse déficit habitacional assustador no nosso país é a urbanização tardia e desordenada. Em concordância com Santos (2009), citado por Monteiro (2017), a urbanização brasileira iniciou-se no século XVIII, no entanto, somente no século XX e principalmente a partir da década de 40, que a urbanização ocorre de forma intensa, resultando em amplas mudanças na morfologia e expansão das cidades e na distribuição da população pelo território nacional.

Para Monteiro (2017), o Brasil passa a ser rapidamente um país predominantemente urbano, que se urbaniza cada vez mais e em grande velocidade. Este fato tem acarretado sérios problemas no desenvolvimento de diversas regiões e vem impactando de maneira direta na estrutura da moradia dos brasileiros. Alinhado a isto, as questões econômicas e políticas vivenciadas nos últimos anos corroboram de maneira direta com o agravamento da situação de vulnerabilidade da população mais carente, o que reflete na atual problemática habitacional.

Uma das alternativas encontradas para o combate ao déficit habitacional foram os programas habitacionais promovidos pelo governo. Contudo, com o decorrer do tempo o déficit habitacional vem crescendo, o que nos mostra que apenas esses programas impulsionados pelo governo não está sendo o suficiente.

Outra forma de tentar amenizar essa deficiência habitacional foi a criação da Lei Federal no 11.888/08 que visa assegurar assistência técnica pública e gratuita para projeto, construção e/ou reforma de habitações para famílias com renda inferior a três salários mínimos. Deste modo, não somente órgãos públicos especializados, como também programas de Extensão Universitária, através de escritórios-modelos ou escritórios-públicos, podem e devem atuar na prestação deste serviço. Ainda de acordo com a legislação do país, o artigo 207 presente na constituição da república, determina que as universidades devem obedecer ao princípio da indissociabilidade entre ensino, pesquisa e extensão, uma tríade que segundo Hennington (2005), envolve a justiça social, solidariedade e cidadania.

Neste aspecto, torna-se possível à Universidade intervir junto à comunidade, utilizando-se dos conhecimentos desenvolvidos por ela, de modo a corroborar de maneira efetiva com políticas públicas que visam minimizar os riscos e a precariedade na concepção de projetos habitacionais de interesse social no país e, assim, contribuir com uma diminuição do déficit habitacional, bem como, o combate da autoconstrução que é uma preocupante ferramenta popular.

A análise do Instituto Brasileiro de Geografia e Estatística - IBGE (2013) mostra que 70\% da população nordestina (arranjos familiares residentes em domicílios particulares) possui rendimento mensal familiar de até um salário mínimo. Como o orçamento muitas vezes dita as regras, essa faixa da população é levada a construir, reformar e fazer manutenção com sua própria mão-de-obra, muitas vezes desqualificada, que procede sem a devida orientação por profissionais da construção civil e de segurança. De acordo com Vidal (2008), esta constitui a principal causa para o baixo desempenho em grande parte das moradias autoconstruídas.

Essa prática, muito comum em famílias que anseiam pela própria moradia, caracteriza-se muitas vezes pelo mau emprego dos materiais de construção, desperdício, e consequente aumento do custo, que causam desqualificação da obra. 
Devido principalmente a essas limitações orçamentárias, parte da população adepta da autoconstrução utiliza áreas impróprias e irregulares, como as áreas de encosta, geralmente consideradas locais de risco do ponto de vista geotécnico, o que acaba não só comprometendo a segurança dos seus moradores, mas também gerando alterações no espaço urbano. Para Abiko e Ornstein (2002) permanece, porém, a triste consciência de que, ao mesmo tempo em que se procede uma abordagem teórica, técnica, legal e mesmo social da questão, suas reflexões estão sendo atropeladas por uma vigorosa realidade, onde milhares de habitações "penduradas" em morros estão surgindo, na maior parte das vezes à revelia de qualquer critério técnico, acumulando áreas de risco e permitindo a antevisão de um quadro cada vez mais preocupante para o futuro.

Com o intuito de colaborar com essa população de baixa renda, vítima da deficiência habitacional, que por falta de assistência técnica construtiva recorre para a autoconstrução, foi desenvolvido o projeto de extensão Escritório Habitar, através da Pró-Reitoria de Extensão (PROEX) da Universidade Federal do Cariri (UFCA), com atuação no desenvolvimento e execução de projetos técnicos de engenharia voltados à população em situação de vulnerabilidade socioeconômica, na região do Cariri cearense.

Também, a prática da extensão universitária constitui uma ferramenta importante na formação dos alunos, pois a partir do processo ensino-aprendizagem coadunadas com o ensino e pesquisa, favorecem o confronto da teoria com o mundo real das necessidades e desejos, que acarretam numa troca de conhecimentos HENNINGTON (2005). Com esse mesmo pensamento, Vidal (2007) afirma que as ações de extensão integram uma dinâmica universitária, que se enreda em fatores como a produção e difusão do conhecimento, promovendo o bem-estar da população.

\section{METODOLOGIA}

O presente trabalho possui característica como uma pesquisa descritiva de caráter qualitativodocumental, com análise e apresentação de resultados alcançados pelo projeto de extensão Escritório Habitar, vinculado a PROEX da UFCA.

O programa utiliza-se dos meios de comunicação para atingir seu público-alvo. Através da divulgação, é possível propagar-se a ação do Escritório Habitar com a finalidade de encontrar pessoas que se enquadrem nos requisitos adotados pelo programa para caracterizar a habitação social. São utilizados meios de comunicação locais, como TV's e rádios, além da internet, através do website (http://escritoriohabitar.ufca.edu.br/) e das mídias sociais. As famílias devem possuir renda comprovada de até três salários mínimos, os projetos desenvolvidos são residenciais tipo térreo e de, no máximo, 80 $\mathrm{m}^{2}$ de área construída, contemplando o projeto arquitetônico, o elétrico, o hidrossanitário, o estrutural e a orçamentação da obra. A forma de cadastro no programa é dada pelo preenchimento do formulário de solicitação, fixado no website do escritório, em conjunto com a documentação exigida para identificação das famílias e comprovação dos requisitos do programa. As famílias escolhidas são intituladas beneficiárias. A seguir, serão descritas, em ordem cronológica, as principais etapas de desenvolvimento da ação.

A primeira etapa consiste na realização de uma visita pela equipe do Escritório Habitar à atual moradia da beneficiária, com caráter avaliativo, sobre aspectos inerentes as condições de habitação e de vulnerabilidade. Após a visita, há a solicitação da documentação para comprovação do perfil socioeconômico em conjunto com os dados obtidos via formulário para posterior análise da documentação.

A segunda etapa consiste na apresentação do portfólio de projetos do Escritório, com três modelos distintos de plantas baixas de até $80 \mathrm{~m}^{3}$ e o levantamento das possibilidades de projetos atreladas às necessidades da beneficiária, afim de identificar particularidades vinculadas às condições financeiras, culturais e físicas dos habitantes, e de viabilidade e segurança da construção. Em caso de reformas, há o levantamento das modificações pretendidas pelos habitantes e das modificações necessárias, atreladas a segurança ou a adequação da construção.

A terceira etapa, consiste no levantamento in loco das medidas necessárias para elaboração e desenvolvimento dos projetos e de todas informações pertinentes à construção, como posição geográfica e a presença das redes de energia elétrica, de água e coletora de esgotos. Nesta etapa são feitos registros fotográficos para documentação e para o auxílio ao desenvolvimento dos projetos.

A quarta etapa é composta por todas as ações que culminam na criação dos projetos até sua finalização e engloba reuniões com a equipe tendo a finalidade de discutir soluções e ideias baseadas nos dados 
levantados, a elaboração dos estudos preliminares, a elaboração dos anteprojetos e a elaboração dos projetos executivos e da orçamentação.

A quinta e última etapa, consiste na entrega de todos os projetos desenvolvidos pelo Escritório, adequadamente impressos e prontos para serem executados, à beneficiária e o acompanhamento pela equipe do Escritório da obra, durante todo processo construtivo.

No início de cada ciclo de vigência do programa existem capacitações dos componentes da equipe do escritório com foco na aprendizagem de métodos e ferramentas para o desenvolvimento das atividades ao longo da vigência do programa. As capacitações possuem o formato de minicursos ou workshops, e são ministradas por parceiros do Escritório, proporcionando o contato dos discentes com profissionais que trabalham cotidianamente com as ferramentas estudadas, e pelos próprios membros do escritório, que possuem algum conhecimento prévio sobre as ferramentas, e compartilham com os demais membros, fomentando o ensino-aprendizagem.

\section{RESULTADOS E DISCUSSÃO}

Considerando os estudos da Fundação João Pinheiro (2015) em relação ao déficit habitacional no Brasil, o estado do Ceará apresenta a segunda maior deficiência em habitação da região nordeste, totalizando um montante de 302.623 mil domicílios, sendo 224.740 mil em área urbana e 77.883 em área rural. Esses dados nos indicam a grande demanda para a necessidade de construção de moradias dignas para população de baixa renda cearense.

Com a ineficiência dos programas habitacionais do governo, associado com a falta de acesso a projetos técnicos e acompanhamento da execução construtiva, essa população inserida em vulnerabilidade socioeconômica acaba por optar pela autoconstrução.

O termo autoconstrução, para Jacob (1981), é um processo de construção ou reforma de uma habitação, comércio, ou instituição, onde a pessoa que gerencia é o próprio dono do imóvel, pode ser também entendida como uma resposta básica de satisfazer determinadas necessidades sociais que não foram supridas a contento. Assim, pode-se notar que a população, especialmente aquela com menor poder aquisitivo, ao deparar-se com a necessidade de executar uma construção ou reforma, acaba agindo de forma autônoma, sem a adoção de critérios técnicos que visem o conforto ambiental e a infraestrutura adequada. Esta realidade que está associada à dificuldade na obtenção de capital suficiente para contratação de profissionais qualificados ou até mesmo à burocracia existente para a realização de empréstimos, resulta no crescimento do número de autoconstrutores no país.

Abaixo seguem imagens de algumas situações de autoconstrução com a presença de patologias e/ou infraestrutura fora dos padrões das normas técnicas brasileiras.

Figura 01 - Rachadura em estado avançado em consequência da autoconstrução

Fonte: autores

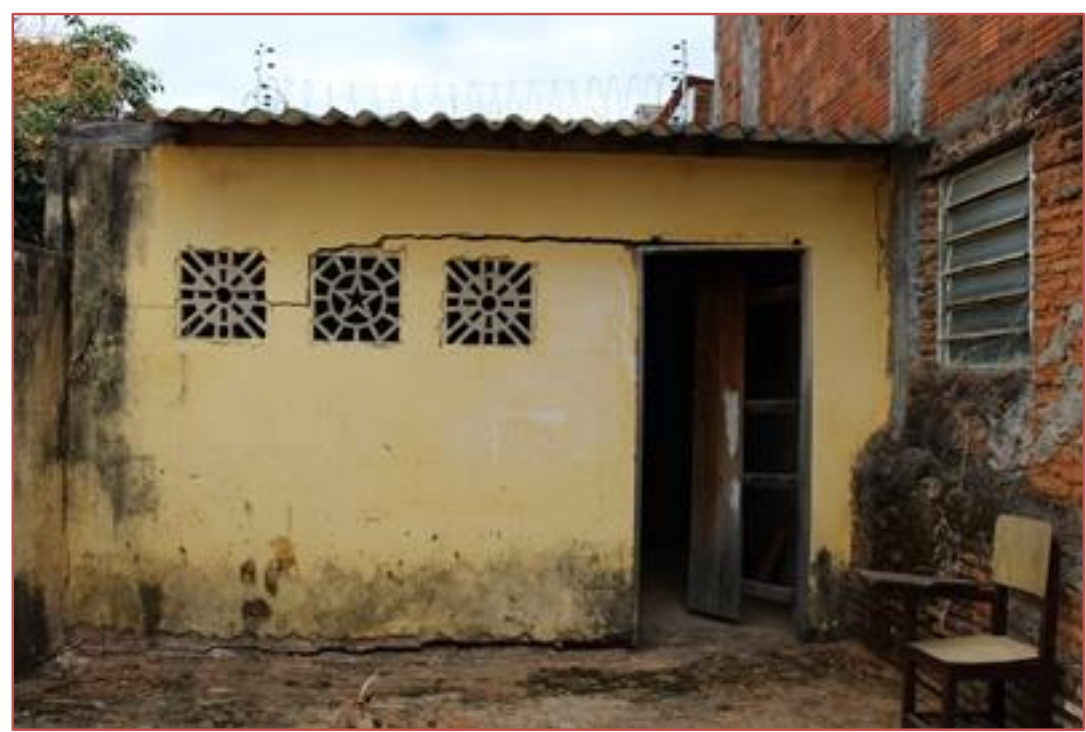


Figura 02 - Desabamento parcial da estrutura devido estado avançado de rachaduras em consequência da autoconstrução

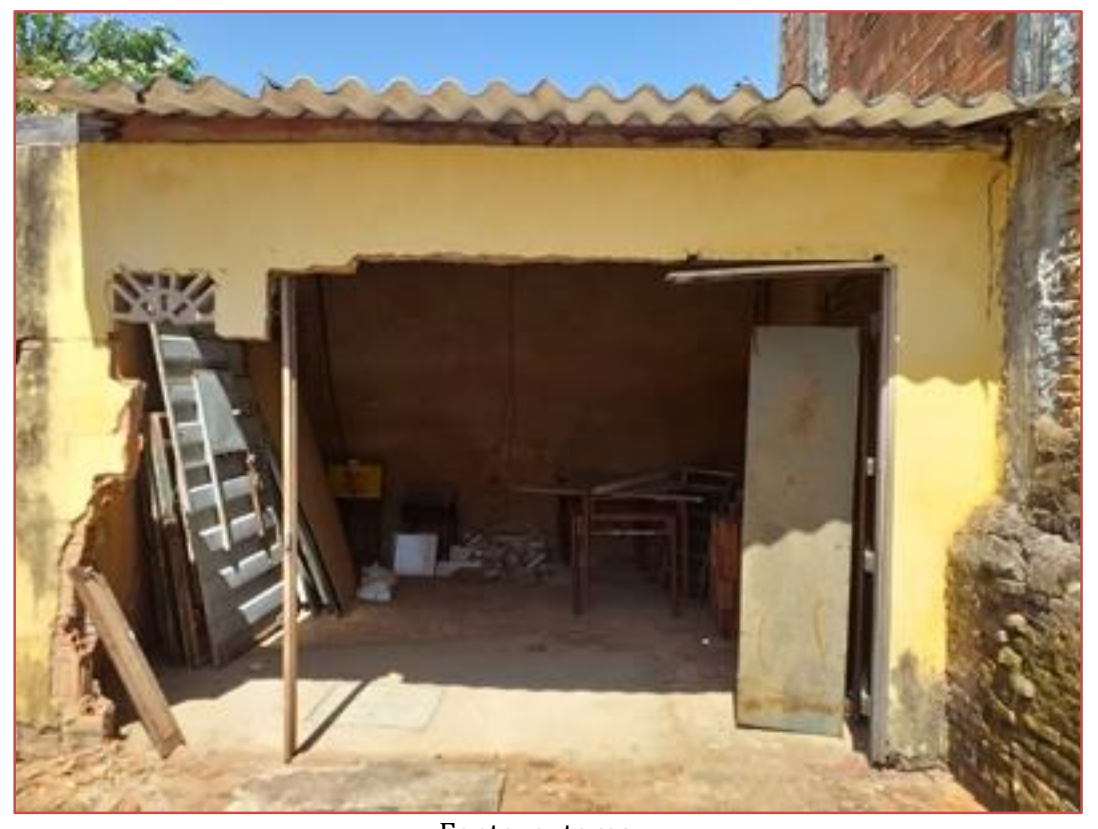

Fonte: autores

Figura 03 - Danificação de pilar para passagem de tubulação de água fria sem auxílio de profissional capacitado

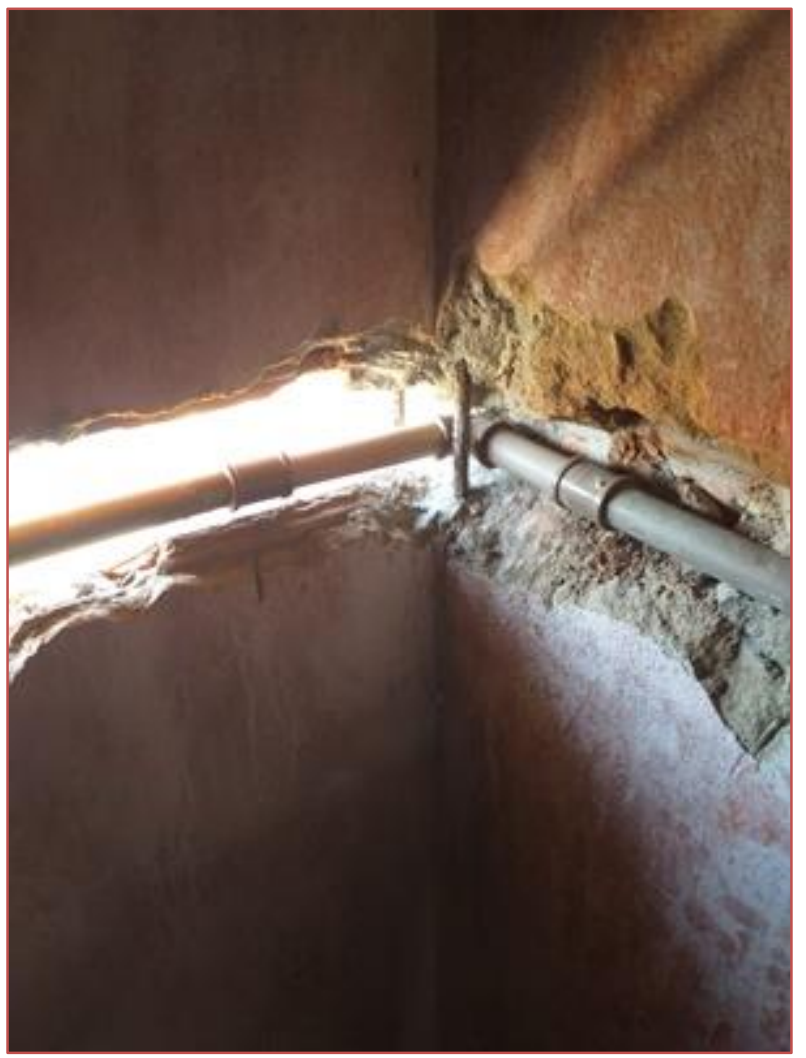


Figura 04 - Viga projetada fora dos padrões das normas técnicas brasileiras com apoio em cobogó

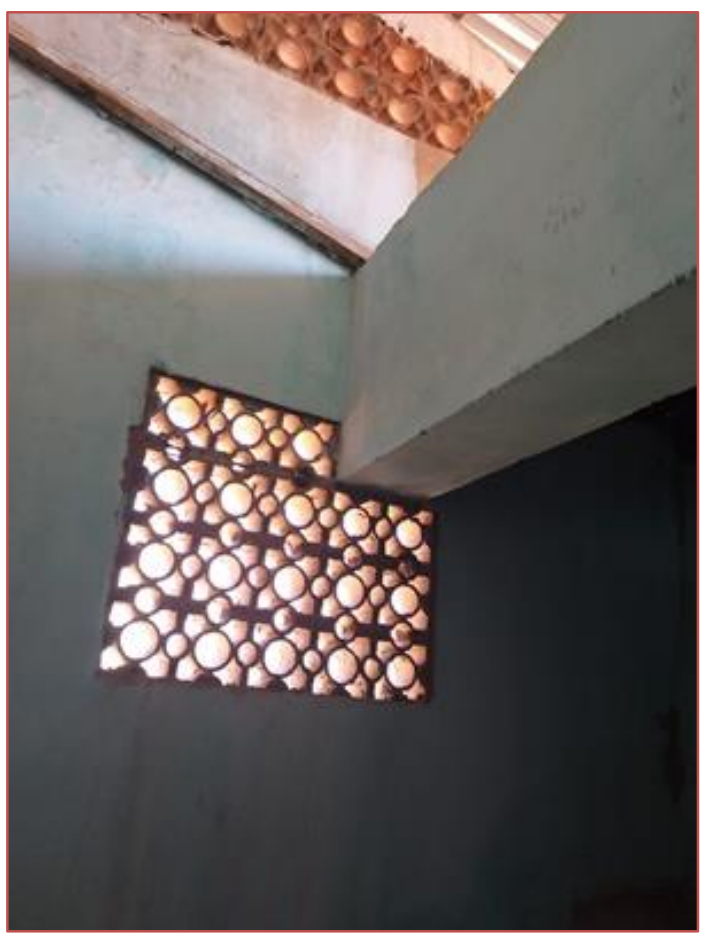

Fonte: autores

Nesse sentido, surge o Escritório Habitar, enquanto ação de extensão, que tem por objetivo assessorar na viabilização do acesso à moradia adequada à população em situação de vulnerabilidade socioeconômica, na Região do Cariri, através de assistência técnica gratuita, nas áreas de arquitetura e engenharia. Para o desenvolvimento de suas atividades, o projeto contou com a participação de discentes do curso de Engenharia Civil da UFCA orientados por docentes da instituição e parceiros, atuando de forma voluntária.

Segue abaixo uma tabela referente a quantidade de beneficiários nos anos de 2017, 2018 e 2019.

Tabela 1 - Famílias em situação de vulnerabilidade social nos anos de 2017, 2018 e 2019

\begin{tabular}{|c|c|c|}
\hline Descrição do público beneficiado & Quantidade de famílias & Ano \\
\hline \multirow{3}{*}{$\begin{array}{l}\text { Famílias em situação de } \\
\text { vulnerabilidade social que desejam } \\
\text { construir e/ou reformar residências }\end{array}$} & 20 & 2017 \\
\hline & 05 & 2018 \\
\hline & 25 & 2019 \\
\hline
\end{tabular}

Fonte: autores

Ao todo foram beneficiadas durante os anos de 2017, 2018 e 2019 cinquenta e cinco (55) famílias em situação de vulnerabilidade socioeconômica, ao qual foram prestadas assistências necessárias de serviços, desde consultoria para reformas à elaboração de projetos residenciais. 0 foco principal do Escritório Habitar é levar aos seus beneficiários a oportunidade de construir de forma segura, primando pela qualidade das técnicas e processos executivos. Dessa forma, as famílias atendidas foram subsidiadas por uma orientação técnica na fase de planejamento da construção e reformas de suas moradias.

A quantidade de famílias atendidas durantes esses três anos estiveram dentro do previsto pelo planejamento do Escritório Habitar, levando em conta algumas limitações apresentadas por esta extensão universitária, já que a ação é voluntária, não envolvendo valores financeiros para custear o projeto.

Uma das metas do Escritório Habitar, mesmo que de forma modesta, é tentar colaborar com a melhoria da problemática de deficiência domiciliar no estado do Ceará que é reflexo do descontrole habitacional brasileiro, apresentando também um crescente déficit de moradia. Em conformidade com a Fundação João Pinheiro (2016), o déficit habitacional do estado do Ceará em 2013 apresentou uma quantidade de 
255.250 mil residências, seguido de 283.102 mil no ano de 2014. E ainda, segundo a Fundação João Pinheiro (2015), um valor de 302.623 mil casas no ano de 2015.

Outro ponto importante é tentar amenizar a carência habitacional para as famílias em com renda de até três salários mínimos. Em pesquisa mais recente, a Fundação Getúlio Vargas (2018) apontou que em termos de distribuição do déficit total por faixas de renda, existe uma forte concentração nas famílias com até 3 salários mínimos. 0 gráfico abaixo indica a necessidade de priorizar programas voltados para sanar o descompasso entre as necessidades habitacionais e a oferta de condições adequadas de moradia nas faixas de renda mais baixas.

Gráfico 01 - Distribuição relativa do déficit habitacional por faixa de renda familiar - 2017

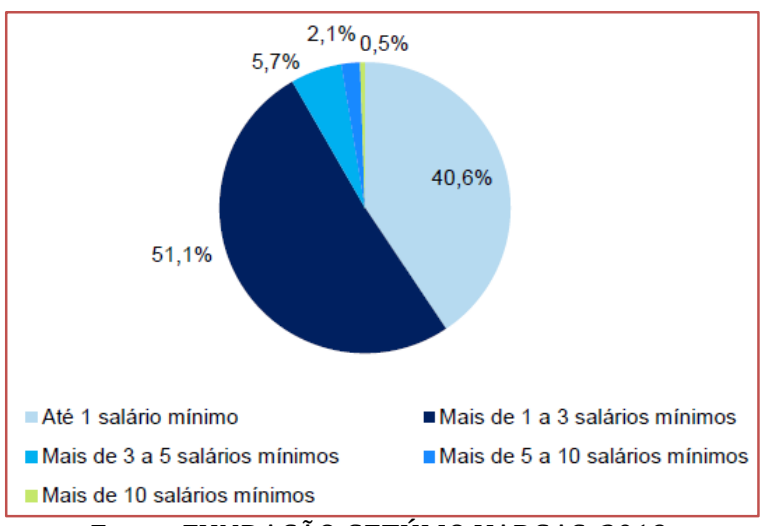

Fonte: FUNDAÇÃO GETÚLIO VARGAS, 2019

Para os discentes bolsistas desse projeto de extensão, os benefícios foram de grande valia, na qual foi possível desenvolver a autoaprendizagem através das capacitações de softwares utilizados para a elaboração dos projetos, já que muitos dessas qualificações eram ministradas pelos próprios bolsistas. Santos (2016), menciona que a autoaprendizagem possui algumas características essenciais, como é o caso da organização temática em torno de problemas, a integração interdisciplinar entrelaçando componentes teóricos e práticos e a ênfase no desenvolvimento cognitivo. Também, o aluno vivencia a complexidade de sua atividade profissional, a qual exige abordagem interdisciplinar e sistêmica e conhecimentos técnicos.

Outro ponto importante é o aperfeiçoamento no domínio tecnológico dos softwares utilizados para a elaboração dos projetos técnicos, o que é indispensável para a formação do engenheiro civil. Pereira (1997) apud Filho (2003) menciona que se os engenheiros são os responsáveis por desenvolver e trabalhar tecnologias, nada mais lógico que eles tenham condições de atende-las além e aquém da pura prática.

\section{CONSIDERAÇõES FINAIS}

Devido ao crescente déficit de moradia no Brasil, associado com a insuficiente política pública habitacional, a autoconstrução tornou-se consolidada, formando um ciclo que ameaça o desenvolvimento de uma infraestrutura construtiva adequada para o bem-estar dessas famílias. 0 Escritório Habitar vem desempenhando exatamente uma solução para o fim desse ciclo, ofertando a criação e execução de projetos técnicos para essas famílias de baixa renda que não estão inseridas nas políticas públicas de habitação.

Uma demanda de beneficiários acima da expectativa do projeto de extensão nos mostra que a autoconstrução ocorre principalmente pela falta de suporte técnicos construtivos, sendo possível reverter essa problemática com a melhoria e expansão de políticas públicas, e inclusive, uma ampliação dos projetos de extensão voltados para projetos técnicos construtivos. Essas atividades extensivas possuem uma fácil implantação e poderiam ser expandidas pelo Brasil, estendendo o número de beneficiário em quantidades significativas no combate ao déficit habitacional e autoconstrução.

A falta de trabalhos publicados nesse ramo é outro problema que poderia ser solucionado com o aumento de projetos de extensão nesse ramo, podendo ser elaborado e disseminado novas técnicas eficazes para 
beneficiar ainda mais essas famílias em vulnerabilidade socioeconômica com o máximo de segurança, conforto, economia e sustentabilidade.

Também, esse projeto de extensão contribuiu ainda para o enriquecimento acadêmico dos estudantes e colaboradores que atuaram na ação. Aos envolvidos foram possibilitados o desenvolvimento da capacidade crítica e o maior aprimoramento em atividades específicas, durante os processos de análise e solução das problemáticas levantadas. A vivência do dia a dia da futura profissão e a experiência obtida por meio do diálogo e atendimento a famílias vulneráveis socioeconomicamente, propiciaram uma gama de conhecimentos que vão além da sala de aula, demostrando uma perspectiva mais humana e altruísta da profissão, tornando-os mais participativos nas questões sociais.

Este modelo de ação extensionista também propicia a ambiência necessária para desenvolver pesquisas, análises e testes na área de utilização de novos materiais de construção, tecnologias alternativas, soluções técnicas voltadas para a economia como também para a sustentabilidade, contribuindo com a população e com o meio ambiente. Dessa forma, cabe a Universidade criar oportunidades que venham propiciar a formação de profissionais cidadãos, utilizando o seu espaço gerador de conhecimento para contribuir com o amplo acesso ao mesmo, bem como gerar melhorias sociais e combater a desigualdades.

\section{REFERÊNCIAS}

[1] ABIKO, Alex Kenya; ORNSTEIN, Sheila Walbe. Inserção Urbana e Avaliação Pós-Ocupação (APO) da Habitação de Interesse Social. Vol.1, São Paulo: Coletânea Habitare, 2002.

[2] BRASIL. Lei no 11.888, de 24 de dezembro de 2008. Assegura às famílias de baixa renda assistência pública e gratuita para o projeto e a construção de habitação de interesse social. Disponível em: http://www.planalto.gov.br/ccivil_03/_Ato2007-2010/2008/Lei/L11888.htm. Acesso em: 10 nov. 2018.

[3] FILHO, A. B.G; PEREIRA, T. R. D. S. A formação profissional de engenharia frente às inovações tecnológicas computacionais. In: XXXI COBENGE, Rio de Janeiro, 2003. Anais. Rio de Janeiro, 2003.

[4] FUNDAÇÃO GETÚLIO VARGAS. Análise das necessidades habitacionais e suas tendências para os próximos dez anos. Associação Brasileira de Incorporadoras Imobiliárias-ABRAINC. Rio de Janeiro, 2018. Disponível em: https://www.abrainc.org.br/wp-content/uploads/2018/10/ANEHAB-Estudo-completo.pdf. Acesso em 07 dez. 2019.

[5] FUNDAÇÃO JOÃO PINHEIRO. Déficit habitacional no Brasil 2015. Diretoria de estatística e informações. Belo Horizonte, 2018. Disponível em: http://www.fjp.mg.gov.br/index.php/docman/direi-2018/estatistica-einformacoes/797-6-serie-estatistica-e-informacoes-deficit-habitacional-no-brasil-2015/file. Acesso em: 12 nov. 2018.

[6] FUNDAÇÃO JOÃO PINHEIRO. Déficit habitacional no Brasil 2013-2014. Centro de estatística e informações. Belo Horizonte, 2016. Disponível em: http://www.fjp.mg.gov.br/index.php/docman/cei/informativos-ceieventuais/634-deficit-habitacional-06-09-2016/file. Acesso em: 12 nov. 2018.

[7] HENNingTON, E. A. Acolhimento como prática interdisciplinar num programa de extensão universitária. Cad. Saúde Pública, Rio de Janeiro, vol.21, n.1, p. 256-265, 2005.

[8] IBGE - Instituto Brasileiro de Geografia e Estatística. Síntese de indicadores sociais: uma análise das condições de vida da população brasileira, 2013. Rio de Janeiro: IBGE. Disponível em: https://biblioteca.ibge.gov.br/visualizacao/livros/liv66777.pdf. Acesso em: 11 nov. 2018.

[9] JACOB, Gorender. A Burguesia Brasileira. São Paulo: Editora Brasiliense, 1981.

[10] MONTEIRO, A. R.; VERAS, A. T. R. A questão habitacional no Brasil. Revista Mercator, Fortaleza, v.16, e. 16015, p. 1-13, 2017.

[11] ONU. Assembleia Geral das Nações Unidas. Pacto Internacional sobre os Direitos Econômicos, Sociais e Culturais. 1966. Disponível em: http://www.unfpa.org.br/Arquivos/pacto_internacional.pdf. Acesso em: 10 nov. 2018.

[12] ONU. Assembleia Geral das Nações Unidas. Declaração Universal dos Direitos Humanos. 1948. Disponível em: https://nacoesunidas.org/wp-content/uploads/2018/10/DUDH.pdf. Acesso em: 10 nov. 2018.

[13] SANTOS, E. F. Benefícios e desafios da aprendizagem baseada em problemas: uma revisão. In: III CONEDU Congresso Nacional de Educação, Rio Grande do Norte, 2016. Anais. Natal: 2016.

[14] VIDAL, C. L. et al. O programa EDUCIMAT: Ensaios e reflexões sobre a extensão universitária. Revista de Educação em Ciência e Matemática, Belém, v.3, n.5 - jul.2006/dez. 2006, v.3 - n.6 - jan 2007/jun.2007, p.43-49.

[15] VIDAL, Fernando Edmundo Chermont. A autoconstrução e o mutirão assistidos como alternativas para a produção de habitações de interesse social. 2008. 165f. Dissertação (mestrado) -Faculdade de Arquitetura e Urbanismo, Universidade de Brasília, Brasília, 2008. 


\section{Capítulo 21}

\section{A possibilidade de um novo olhar para o que está ao seu redor, com Daseinsanálise}

\section{Rôsmari Lisboa Lopes}

Resumo: Este trabalho se refere a uma reflexão sobre o significar da existência com um desenrolar terapêutico numa história fictícia usando daseinsanálise no tratamento terapêutico de Sidarta, um brâmane, personagem da obra de Hermann Hesse (1967). Os acontecimentos transitam por realidades de épocas diferentes, pois o trabalho terapêutico que acontece não existiria em 1600, época usada, neste enredo, para o decorrer dos fatos na vida deste paciente. 0 processo terapêutico então vem através da daseinsanálise como uma forma de criar um espaço para que o paciente possa olhar para sua trajetória com um novo olhar e poder então ressignificar o que julgava errado em sua vida. Conforme HUSSEL (1988), a consciência empregada pela fenomenologia com a capacidade, a imaginação transcendental, que tem uma infinita capacidade de dar incontáveis formas de sentido e que pode estar aprisionada num conceito único. A construção do processo terapêutico fictício foi desenvolvido como uma forma de oportunizar o aprendizado através de uma experiência do estudante de psicologia se colocar no lugar de terapeuta. Podendo executar assim o seu papel na minimização de sofrimento e neste caso de auxiliar no ressignificar da existência do ser em sofrimento.

Palavras-chave: daseinsanálise; ressignificar; processo terapêutico. 


\section{INTRODUÇÃO}

Este trabalho se refere a uma reflexão sobre o significar da existência com um desenrolar terapêutico numa história fictícia usando daseinsanálise no tratamento terapêutico de Sidarta, um brâmane, personagem da obra de Hermann Hesse (1967). Os acontecimentos transitam por realidades de épocas diferentes, pois o trabalho terapêutico que acontece não existiria em 1600, época usada, neste enredo, para o decorrer dos fatos na vida deste paciente.

O processo terapêutico se dá num centro comunitário onde a psicoterapeuta Rôsmari (eu) o atende por um período de seis meses com encontros semanais, tendo cada encontro um tempo de uma hora e meia aproximadamente.

Sidarta é um brâmane, admirado por seu povo, no entanto sentindo-se infeliz e com um vazio existencial. Deixa a casa de seus pais para sair com um amigo em busca de sabedoria, paz espiritual e felicidade. Porém na sua caminhada passa por decepções, desilusões e frustrações, porque não encontra suas respostas nos grupos de nômades que são considerados sábios.

Neste processo de busca, passa a andar sozinho, pois escolhe seguir quando seu amigo decide ficar em um dos grupos. Porém conhece uma bela mulher que o seduz e que motiva a ser comerciante, no entanto esse momento seu comportamento muda radicalmente. Começa a jogar a dinheiro, agindo sem escrúpulos e bebendo álcool rotineiramente. Continua sozinho e vive dias de farra consecutivos até que percebe-se em atitudes repugnantes. Querendo sair desta situação sai pela rua sem rumo e com comportamento de que havia perdido a razão. E em meio a um profundo desanimo encontra, sentado na rua, um mendigo que com seu cachorro transparece feliz. Senta-se então ao lado deste e começa contar-lhe sobre sua história. 0 mendigo lhe aconselha a procurar o centro comunitário porque lá encontraria psicóloga e possivelmente auxílio para seus conflitos. Sidarta vai até o local em busca de ajuda. E neste momento também descobre que a mulher que um dia o seduziu está doente e que irá morrer, deixando uma criança, que é filho de Sidarta, aos cuidados dele.

Há um conflito existencial decorrente da forma que Sidarta significa o mundo, sua trajetória, seu espaço. Tem a dificuldade da relação com o mundo, com o outro e consigo mesmo, dificuldade nas relações. Uma cobrança de si e do outro. Preocupa-se com seu futuro e com os erros do passado, o tempo decorrido e o que virá. Com sua trajetória, com seus fracassos, com sua obra diferente do que almejava. 0 vazio existencial que atormenta Sidarta pode se dizer que é o nada, é a angustia da busca de um sentido para a existência. E pode se pensar então que há um vazio dando a oportunidade de ser preenchido com uma nova maneira de estar no mundo.

Conforme AUGRAS (2009) o momento do encontro entre o psicólogo e o cliente é a atualização do encontro entre o eu e o outro. E assim o terapeuta inicia o processo com Sidarta.

0 processo terapêutico então vem através da daseinsanálise como uma forma de criar um espaço para que o paciente possa olhar para sua trajetória com um novo olhar e poder então ressignificar o que julgava errado em sua vida e rever o que pensava sobre nada ter sido como ele esperava em sua busca. SCHNEIDER (2011) coloca a relação com o corpo conforme Sartre, do corpo-em-si e do corpo-para-si. o corpo-em-si é como os outros vêem o corpo, como é para o outro e o corpo-em-si é como sou, como é para o próprio ser. E Sidarta encontra o outro para ter a oportunidade de poder olhar-se e para poder ter um espaço para pensar de fora de si, fora de seus sentimentos e de seu julgar-se.

Conforme HUSSEL (1988), a consciência empregada pela fenomenologia com a capacidade, a imaginação transcendental, que tem uma infinita capacidade de dar incontáveis formas de sentido e que pode estar aprisionada num conceito único. Sidarta refletindo, pode ter um espaço para respirar/repensar dentro do tumulto interno que se encontrava. Conforme HEIDEGGER (2007) "... entregue a essência do que se descobre e de seu descobrimento...".

Nos escritos de HEIDEGGER (1989) o homem é ser aí (dasein). 0 ser aí é sempre ser no mundo, ser com os outros. 0 ser aí inacabado até a morte. 0 ser é subjetividade e transcendência, com possibilidade de se reconstruir e se reestruturar. 0 ser em abertura, aberto nele mesmo, é disposição e compreensão. 0 ser enquanto possibilidade de ser no mundo. Em angústia lança-se a possibilidade de ser mais próprio. E tem o cuidado como condição existencial.

O homem é um ser livre e responsável por sua liberdade, ele é o que é por ter essa liberdade de se fazer ser. Forma-se de maneira singular e ao mesmo tempo universal. E conforme SCHNEIDER (2011) é no processo de apropriação do seu externo (social, antropológico e físico), de forma singular, que constrói sua subjetividade que vai se objetivar em seus atos, suas emoções. O ser se constitui nas suas relações, com 
seu exterior, tendo, portanto influência do meio social, família, cultura, etc. Assim por tanto subjetiva a objetividade, sendo então a subjetividade uma apropriação da objetividade, esta se dá nesse processo dialético. Pensando assim, conforme AUGRAS (2009), a consciência é uma doadora de sentido para o mundo.

Sidarta chega para a terapia com a queixa de sair em busca de sua sabedoria, para ser um homem sábio na velhice e com o desgosto de ter feito de seu caminho percorrido como um fracasso. Em relação ao tempo e na relação com o tempo SCHNEIDER (2011) coloca que quem dita a temporalidade é o ser humano já que esta existe porque o ele existe. Também coloca que se faz uma síntese dialética entre passado, presente e futuro, pois é no que realiza, constrói, ama e é amado, sofre, é que vai se constituindo como ser; bem como projetar-se, querer ser alguém. "O homem faz a história na mesma medida em que a história o faz". Projetado pelo futuro, que é um possível vir a ser, faz o seu passado, construindo no presente, que rapidamente vira passado, e assim se faz a síntese temporal. Podemos ver que Sidarta mostra que vive sua história, faz seu passado pela motivação do seu futuro, do seu vir a ser. É produtor e produto da dinâmica temporal.

E nessa construção temporal vem o significar, que vai acontecendo conforme a emoção que aparece nesse descontentamento e questionamento da existência. E conforme a busca Sidarta vai transformando-se emocionalmente mostrando motivação e desilusão até seus momentos de desespero que o faz andar sem rumo. Assim pode-se dizer que o homem é psicofísico, pois seu emocional se mostra em suas manifestações corpóreas. 0 corpo pode inclusive adoecer devido ao seu emocional, porque é a manifestação sem fala, é como vai expressar o que está sentido. Pode-se pensar então o ser como físico, psíquico, relações, mundo, significar, projeto, temporalidade.

No decorrer do processo terapêutico Sidarta consegue observar conquistas e sucessos em sua vida que não conseguia ver em seu passado. Percebe o quanto importante foi muitos dos momentos que viveu e que considerava apenas tropeços e conflitos. Descobre o valor de ter um filho, o que não tinha ainda parado para pensar. Consegue mudar sua forma de agir para com o seu filho fazendo do conflito uma conversa com perspectivas positivas, mostrando uma nova forma de relacionar-se com seu mundo e com o social. Também consegue pensar seu futuro com possibilidades, o oposto do que pensava anteriormente. Consegue ver a possibilidade de construir sua sabedoria. E com relação ao que viveu teve um novo olhar podendo dar um novo significado ao que considerava fracasso. Que os momentos que viveu e que não foram como esperava também tiveram seus valores acrescentados à sua história de vida, ou seja, pode ver o seu projeto de ser e resignificar o seu passado vendo assim suas possibilidades de ser.

\section{METODOLOGIA}

Este trabalho foi desenvolvido com a liberdade de criar um processo terapêutico com o personagem da obra de Hemann Hesse de 1967, podendo trabalhar dentro dos conceitos das teorias humanistas, desenvolvendo um processo de experiência e aprendizado dentro da disciplina de teorias psicoterápicas III no curso de psicologia.

O desenrolar se dá com o discorrer de encontros terapêuticos fictícios onde o paciente traz as suas dificuldades e conflitos e a terapeuta (autora - Rôsmari) faz seu trabalho de acolhimento inicial desenvolvendo sequencialmente, em encontros subsequentes, um processo de oportunizar, a Sidarta, a possibilidade resignificar o projeto de ser no mundo.

\section{RESULTADOS E DISCUSSÃO}

A construção do processo terapêutico fictício foi desenvolvido como uma forma de oportunizar o aprendizado através de uma experiência do estudante de psicologia se colocar no lugar de terapeuta. Podendo executar assim o seu papel na minimização de sofrimento e neste caso de auxiliar no ressignificar da existência do ser em sofrimento.

\section{CONCLUSÕES}

Este trabalho pode proporcionar um momento de aplicar a teoria num atendimento irreal, com a liberdade de usar a criatividade para imaginar as possíveis demandas que podem aparecer e que talvez sem essa oportunidade não a viveria neste período de graduação. Trabalhando a sensação de estar 
terapeuta como tal e poder despertar a criatividade de pensar características no paciente, aprimorando a capacidade de atuar na vida profissional real.

\section{REFERÊNCIAS}

[1] Augras, M. O ser da compreensão: fenomenologia da situação de psicodiagnóstico. 9.ed. Petrópolis: Vozes, 2009.

[2] Heidegger, M. A questão da Técnica. V.5, São Paulo: Scientlae Studia., 2007.

[3] _ _ Ser e Tempo. 15 ed. Petrópolis: Vozes, 2005.

[4] C C C C _ Conferências e escritos filosóficos. São Paulo: Nova Cultural, 1989.

[5] Hussel, E. Invesitgações Lógicas. Sexta Investigação (Elementos de uma elucidação fenomenológica do Conhecimento. São Paulo: Nova Cultural, 1988.

[6] Sartre, J. P. Esboço para uma teoria das Emoções. 1 ed. Porto Alegre: L\&PM, 2008.

[7] _ $\quad$ O S Ser e o Nada. 15 ed. Petrópolis: Vozes, 2005.

[8] Schneider, D. Sartre e a psicologia clinica. 1 ed. Florianópolis: UFSC, 2011.

[9] Branco, J. L. C. C. A angústia na obra de ingmar bergman: sarabanda em ser e tempo de martin heidegger, Universidade presbiteriana mackenzie castejón branco. Disponível em: http://www.educadores.diaadia.pr.gov.br/arquivos/File/2010/artigos_teses/2010/Arte/dissertacao/filme_ing_berg. pdf. Acesso em 20 mai. 2015.

[10] Feijoo, A. M. L. C. A clínica Daseinsanalítica: considerações preliminares. Rev. abordagem gestalt., Goiânia, v. 17, n. 1, jun. 2011 . Disponível em <http://pepsic.bvsalud.org/scielo.php?script=sci_arttext\&pid=S180968672011000100006\&lng=pt\&nrm=iso >. acessos em 20 mai. 2015.

[11] Silva, E. R. Psicologia clínica, um novo espetáculo: dimensões éticas e políticas. Psicol. cienc. prof., Brasília , v. 21, n. 4, p. 78-87, Dec. 2001. Available from <http://www.scielo.br/scielo.php?script=sci_arttext\&pid=S141498932001000400009\&lng=en\&nrm=iso >. access on 20 mai. 2015. http://dx.doi.org/10.1590/S141498932001000400009 . 


\section{Capitulo 22}

Direita ou esquerda? Como está sua lateralidade? Um estudo envolvendo acadêmicos do curso de pedagogia da UFPI

Raylane Virginia Venancio Ferreira Lima

Antonia Shirley Ferreira dos Santos Brito

Antonia Sandra Veras Lélis

Dionis de Castro Dutra

Resumo: 0 presente estudo investigou as habilidades psicomotoras referentes à lateralidade dos graduandos do 5 o período do curso de Pedagogia da Universidade Federal do Piauí, tendo por objetivo analisar a compatibilidade entre o desenvolvimento da lateralidade e o estágio de desenvolvimento motor em que os mesmos deveriam se encontrar em razão da idade cronológica apresentada. 


\section{INTRODUÇÃO}

0 termo lateralidade é utilizado para definir a preferência que o indivíduo tem por um dos membros do corpo ou órgão do sentido ao realizar as atividades motoras cotidianas, a qual pode ser classificada como homogênea, cruzada e ambidestra. A lateralidade homogênea representa a dominância de um mesmo lado do corpo, nos segmentos ocular, manual e pedal. A lateralidade cruzada apresenta variações na dominância de uma das partes do corpo, como olho esquerdo, perna esquerda e mão direita. Já na ambidestra pode-se usar tanto o lado direito quanto o esquerdo para executar com eficiência uma tarefa, mesmo não deixando definida uma preferência lateral. 0 conceito de lateralidade admite um componente multidimensional e dinâmico. Assim, à medida que o ser humano envelhece, supõe-se que ele se torne mais lateralizado, com tendência à preferência manual direita. ${ }^{1}$

Nesta perspectiva, dois fatores influenciam a escolha dos membros ou órgãos dos sentidos na lateralização: a filogenia (desenvolvimento da lateralidade via ação genotípica) e a ontogenia (desenvolvimento da lateralidade por meio das experiências práticas). Investigações voltadas à filogenia constataram que os fetos e neonatos apresentavam preferências precoces por uma das mãos. Em um desses estudos, 72 fetos foram analisados e destes, 63 demonstraram preferência por um dos membros superiores, ainda com apenas 10 semanas de vida intrauterina, sendo que $85 \%$ mostrou preferência pelo membro superior direito. ${ }^{2}$ Estudo similar observou 75 fetos e fez uma análise da lateralidade até quanto atingiram a idade de 10-12 anos, e constatou que 60 fetos que movimentaram o braço direito, todos tornaram-se destros (80\%); e 15 dos fetos mais ativos com o braço esquerdo tornaram-se canhotos. ${ }^{3}$ Tais estudos apontam que a lateralidade começa a ser definida antes mesmo do nascimento. ${ }^{4}$

Na ontogenia, a ênfase é dada à influência do ambiente sobre a preferência lateral, afirma-se que as experiências práticas com um segmento corporal podem determinar a lateralidade, além de reconhecer que há uma pressão social pelo uso da mão direita. A população mundial é classificada em destrímanos ou sinistrómanos, sendo a taxa de canhotos menor que destros. Entretanto, pesquisas apontam as pessoas sinistrómanos mais proficientes com a sua mão não preferida em razão do seu processo adaptativo à sociedade primordialmente destra. ${ }^{5}$

As consequências de uma lateralidade mal definida incluem prejuízos ao desenvolvimento e execução das ações motoras, principalmente na orientação espaço-temporal. Ainda na infância as crianças com problemas na lateralização do seu corpo podem apresentar dificuldades no traço caligráfico, nas combinações de letras e números, habilidades verbais e não verbais, podendo acarretar graves transtornos de aprendizagem, como disgrafia, dislexia ou discalculia. ${ }^{6} 0$ desenvolvimento da lateralidade aprimora o desempenho motor que é essencial para o desenvolvimento conceitual e cognitivo. A lateralidade orienta o esquema corporal, sendo necessário seu desenvolvimento para que na fase adulta o indivíduo tenha alcançado as habilidades máximas de lateralização. Quando isso não ocorre, o adulto pode ter problemas como: quedas por ser desajeitado, atenção instável, leitura comprometida e discriminação visual limitada. ${ }^{7}$

0 presente estudo investigou as habilidades psicomotoras referentes à lateralidade dos graduandos do 5 o período do curso de Pedagogia da Universidade Federal do Piauí, tendo por objetivo analisar a compatibilidade entre o desenvolvimento da lateralidade e o estágio de desenvolvimento motor em que os mesmos deveriam se encontrar em razão da idade cronológica apresentada.

\section{METODOLOGIA}

\subsection{CARACTERIZAÇÃO DA PESQUISA/COMPOSIÇÃO DA AMOSTRA}

Trata-se de uma investigação de caráter quantitativo, no que se refere a natureza dos dados, sendo classificada como pesquisa de campo por ter em seu delineamento coletas, registro de dados e informações relativas ao objeto de estudo. A pesquisa ocorreu em junho de 2019 na cidade de Teresina-PI e consistia em atividade prática da disciplina Motricidade e Escola do curso de Pedagogia da Universidade Federal do Piauí-UFPI. A amostra desta pesquisa foi composta por 21 graduandos de uma turma de $5^{\circ}$ período do Curso de Pedagogia da UFPI.

Os voluntários foram esclarecidos quanto à finalidade e objetivos da presente pesquisa e autorizaram sua participação na mesma. Além disso, foi garantido o direito à confidencialidade dos dados coletados, não sendo os participantes identificados no estudo. A pesquisa considerou os aspectos éticos estabelecidos na Resolução CNS 466/12, a qual determina diretrizes para pesquisas envolvendo humanos. 


\subsection{INSTRUMENTOS DE COLETA DE DADOS}

Uma ficha de avaliação psicomotora elaborada a partir da obra de Oliveira (2014) ${ }^{8}$ foi utilizada para detectar o estágio de desenvolvimento psicomotor dos estudantes. Este instrumento compunha-se de cinco eixos de análise (coordenação e equilíbrio; esquema corporal; lateralidade; estrutura espacial; e estrutura temporal). Para esse trabalho foi feito um recorte na ficha de avaliação, sendo analisado apenas o eixo referente à lateralidade.

A ficha de avaliação psicomotora na parte referente a lateralidade é composta por exercícios de identificação, reconhecimento e orientação da direita e esquerda no corpo e em outros corpos; observação da mão, pé e olho dominante; tipo de dominância presente; e reprodução de movimentos relacionados com o lado direito ou esquerdo do corpo. Tendo ao final de cada eixo das atividades uma pontuação que variava de 0 a 4 pontos, 0 a 6 pontos ou 0 a 8 pontos, ademais foram classificadas a dominância dos participantes em homogênea, cruzada e indefinida.

As atividades do eixo da lateralidade totalizavam entre 0 e 34 pontos para classificar o estágio de desenvolvimento motor em que o indivíduo se encontrava. Ao todo são cinco estágios de desenvolvimento psicomotor, são eles: I- Imagem de corpo vivido (até 3 anos); IA- Reorganização do corpo vivido (3 a 4 anos); IB- Indícios de presença de imagem de corpo percebido (5 a 6 anos); II- Imagem do corpo percebido (7 anos); IIA- Reorganização do corpo percebido (8 a 9 anos); IIB- Indícios de presença do corpo representado (10 a 11 anos); e III- Imagem de corpo representado (a partir de 12 anos).

A pontuação de 0 a 34 pontos para o item lateralidade está subdivida nos sete estágios do desenvolvimento psicomotor, conforme quadro 1.

Quadro 1: apresentação dos estágios do desenvolvimento psicomotor e a pontuação desejável para cada estágio específico.

\begin{tabular}{|c|c|c|c|c|c|c|c|}
\hline Estágios do desenvolvimento & I & IA & IB & II & IIA & IIB & III \\
\hline Pontuação desejável em lateralidade & 2 & 3 a 9 & $\begin{array}{c}10 \text { a } \\
16\end{array}$ & 17 & $\begin{array}{c}18 \text { a } \\
25\end{array}$ & $\begin{array}{c}26 \text { a } \\
33\end{array}$ & 34 \\
\hline
\end{tabular}

\section{DESENVOLVIMENTO}

A lateralidade é influenciada por fatores genéticos, mas também pelo ambiente em que o bebê é inserido, os aspectos culturais da sociedade e pelo tipo de tarefa desempenhado pelo indivíduo no decorrer de seu desenvolvimento motor. Algumas pesquisas encontraram uma relação entre visualização do braço com a preferência manual nos bebês, e constataram que os bebês com desenvolvimento típico ao ter um contato visual repetitivo com um de seus braços inclina frequentemente a cabeça para o lado esquerdo ou direito. Essa ação promove mudança no sistema nervoso, específicas ao hemisfério cerebral mais ativo, podendo gerar uma preferência lateral por um dos braços. A frequência de execução de tal gestual pode contribuir para assimetrias nas redes neurais relacionadas à preferência manual e diferenças no desempenho motor dos segmentos. Assim, o uso mais frequente de um dos membros superiores e a orientação dos movimentos decorrente do feedback visual possibilitariam um refinamento motor no uso deste segmento. A partir daí, a preferência lateral se estabelece com base na diferença da capacidade de controle entre membros, dando primazia ao segmento que desempenha melhor os movimentos requeridos. ${ }^{9}$

Ainda no campo da ontogenia, foi realizado um estudo com 1800 famílias havaianas tendo como público alvo netos, pais e avós. Após a análise constatou-se que apenas $10-20 \%$ da preferência manual dessa população tinha relação com a hereditariedade e sendo o ambiente o principal agente na formação lateral dos indivíduos. ${ }^{10}$ Outras pesquisas desta área apontam para as exigências culturais de algumas sociedades para o uso de uma determinada mão para escrever e se alimentar, como por exemplo a pesquisa de Meng $(2007)^{11}$ nas escolas coreanas, observou-se que $59 \%$ das crianças pesquisadas foram pressionadas a mudarem sua mão preferida e, após um período de tempo, $61 \%$ destas crianças começaram a utilizar a mão direita para realizar as ações motoras. Esses estudos buscam apontar que a incidência de destrímanos e sinistrômanos é fortemente estabelecida socialmente e que a lateralidade não seria preestabelecida ao nascer. ${ }^{4}$ 
Desde a mais tenra idade o ser humano desenvolve movimentos que irão contribuir para o repertório motor de toda a sua vida. 0 período da infância oportuniza o desenvolvimento motor especialmente por meio de jogos e brincadeiras. Tal fase é crucial para o desenvolvimento pleno da lateralidade e, quando negligenciada, promoverá prejuízos no desenvolvimento de atividades laborativas, de lazer e vida diária pois afeta diretamente a coordenação motora e a proficiência manual. Além disso, outra consequência do mau desenvolvimento da lateralidade está relacionada com o equilíbrio, o indivíduo sente dificuldades em ficar em uma posição estática, no apoio unipodal e em executar movimentos básicos em tarefas que exijam força ou precisão. ${ }^{12}$

Uma forma de combater as negligências relacionadas a lateralidade é o uso de avaliações psicomotoras, cuja finalidade consiste em investigar o processo evolutivo e intervir precocemente em atrasos psicomotores de crianças. A avaliação psicomotora permite a educadores e profissionais da área da saúde intervirem de modo a promover explorações sensório-motoras diversificadas, auxiliando no desenvolvimento correto da lateralidade. ${ }^{8}$

\section{RESULTADOS E DISCUSSÃO}

A análise ocorreu com 21 discentes do curso de Pedagogia da UFPI, dos quais 85,7\% do gênero feminino e $14,3 \%$ do gênero masculino. 0 quadro 2 apresenta os valores de média e desvio padrão da pontuação obtida nos itens avaliados na amostra.

Quadro 2: valores de média e desvio padrão dos itens avaliados quanto à lateralidade.

\begin{tabular}{|c|c|c|c|c|c|c|c|c|c|}
\hline \multicolumn{6}{|c|}{ Dominância } & \multicolumn{2}{|c|}{ Orientação D e E } & \multicolumn{2}{|c|}{$\begin{array}{l}\text { Reprodução do } \\
\text { movimento }\end{array}$} \\
\hline \multicolumn{2}{|c|}{ Manual } & \multicolumn{2}{|c|}{ Ocular } & \multicolumn{2}{|c|}{ Pedal } & $\begin{array}{c}\text { Em si } \\
\text { mesmo }\end{array}$ & $\begin{array}{c}\text { Face a } \\
\text { face }\end{array}$ & $\begin{array}{c}\text { Em } \\
\text { figuras }\end{array}$ & De objetos \\
\hline D & E & D & E & D & E & & & & \\
\hline $\begin{array}{c}6,95 \\
( \pm 1,35) \\
\end{array}$ & $\begin{array}{c}0,19 \\
( \pm 0,60)\end{array}$ & $\begin{array}{c}2,62 \\
( \pm 1,85)\end{array}$ & $\begin{array}{c}1,24 \\
( \pm 1,84)\end{array}$ & $\begin{array}{c}3,62 \\
( \pm 0,97)\end{array}$ & $\begin{array}{c}0,19 \\
( \pm 0,87)\end{array}$ & $\begin{array}{c}5,90 \\
( \pm 0,30)\end{array}$ & $\begin{array}{c}3,43 \\
( \pm 0,81)\end{array}$ & $\begin{array}{c}3,67 \\
( \pm 0,73)\end{array}$ & $\begin{array}{c}3,90 \\
( \pm 0,30)\end{array}$ \\
\hline
\end{tabular}

D- direita; E- esquerda

O gráfico 1 apresenta a distribuição dos voluntários da pesquisa quanto à classificação da dominância.

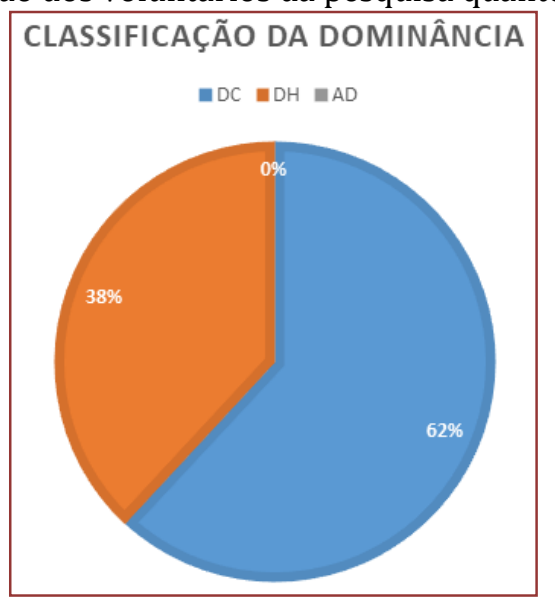

DC- Dominância cruzada; DH- Dominância Homogênea; AD- Ambidestra.

A pontuação geral na avaliação da lateralidade apresentou média 33,33 $( \pm 1,88)$, ou seja, ligeiramente abaixo do mínimo esperado para a faixa etária do público avaliado. Os resultados também permitiram constatar que $57,1 \%$ dos futuros pedagogos estavam classificados no estágio psicomotor III que corresponde à imagem de corpo representado e que é o nível esperado para aqueles que têm acima de 12 anos de idade. Já 42,9\% dos futuros professores estavam classificados no estágio IIB que consiste num estágio em que há inícios da presença do corpo representado, o qual é atribuído a faixa etária de 10 a 11 anos de idade. Cabe destacar que considerável parcela da amostra não se encontrava no estágio de desenvolvimento psicomotor esperado para a faixa etária. Não houve nenhum voluntário classificado em níveis inferiores ao IIB para o desenvolvimento psicomotor relacionado à lateralidade. 
Parte dos discentes envolvidos na pesquisa não estavam classificados no nível de desenvolvimento psicomotor esperado para a idade. A análise constatou que os mesmos encontravam-se em um estágio abaixo do previsto. Os envolvidos nesse estudo não apresentavam nenhuma limitação física ou doenças crônicas que os impedissem de realizar os testes propostos na avaliação psicomotora e, neste caso, descarta-se a possibilidade de problemas físicos serem a origem do atraso evolutivo.

Uma possível razão para os graduandos possuírem uma lateralidade mal desenvolvida é um ambiente familiar empobrecido de experiências sensório-motor e falta de intervenção adequada nos anos dedicados a educação infantil e ensino fundamental. Os pais muitas vezes não sabem da importância de expor os filhos a diferentes tipos de tarefas, como por exemplo, pegar um objeto, pular, chutar, caminha em linha reta, fazer um percurso que envolva diferentes movimentos corporais, entres outras que auxiliem à criança a desenvolver desde equilíbrio gravitacional e motricidade global. Ademais, há núcleos familiares que superprotegem as crianças, privando-as de experiências sensórias necessárias ao seu desenvolvimento. ${ }^{13}$

Entretanto as creches, pré-escola e escola deveriam realizar testes diagnósticos visando diminuir efeitos negativos no desenvolvimento da criança. As unidades educacionais são instituições preparadas para trabalhar a hierarquização da motricidade humana: coordenação visomotora, espaço perceptivo-motor, equilíbrio, postura, dinâmica corporal, tempo, ritmo, concentração, discriminação esquerda/direita, motricidade global, motricidade fina, linguagem, esquema corporal e servem como ambiente rico para experiências sociais, afetivas e sensoriais que ajudem na evolução da inteligência da criança. ${ }^{14}$ No entanto, por vezes o âmbito escolar não reconhece o papel da psicomotricidade para a formação e evolução do ser humano, focando apenas na linguagem, aquisição da língua escrita e aprendizado da matemática; negligenciando um aprendizado importante para o indivíduo durante toda a vida e necessário para realizar atividades que variam do simples ao complexo, bem como interferindo na carreira profissional dos mesmos quando adultos.

Mesmo uma defasagem pequena pode ter consequências para a vida do indivíduo e sua atuação no campo educacional. Os futuros educadores por apresentarem comprometimento em sua lateralização terão dificuldades em propor dinâmicas e atividades que auxiliem as crianças a desenvolverem a lateralização, principalmente as relacionadas à localização no espaço, noção de esquerda ou direita em si mesma ou no outro. Ademais, podem cometer erros relacionados à educação psicomotora que podem confundir os alunos ou até fazê-los construir conceitos errados sobre a lateralidade. Os discentes podem sair da educação infantil e/ou ensino fundamental com graves comprometidos que dificultaram sua ação motora com precisão, força e agilidade, além de afetar diretamente no processo de alfabetização, uma vez que a criança precisa ter consolidado as noções de esquema corporal para poder compreender a lógica da leitura e escrita. ${ }^{10,14}$

\section{CONSIDERAÇÕES FINAIS}

Diante das análises feitas, pôde-se constatar que considerável parte dos graduandos do curso de Pedagogia da UFPI envolvidos na pesquisa não apresentavam compatibilidade entre o desenvolvimento da lateralidade e o estágio de desenvolvimento motor adequado a idade cronológica. Os estudantes encontram-se em um estágio abaixo do esperado para a idade e tal fato interfere de alguma forma nas ações realizadas pelo indivíduo ou em sua atuação docente. 0 processo de formação inicial deve ofertar um estudo amplo e sistemático das questões que envolvem a motricidade humano, os futuros profissionais mesmo com uma pequena desfasagem em sua lateralização precisam saber da importância da lateralidade para a evolução das crianças. Os graduandos, por meio desses saberes, poderão construir estratégias que os auxiliem a minimizar suas dificuldades e a interferência das mesmas em sua práxis.

\section{REFERÊNCIAS}

[1] Faquin Bruno Secco, Candido Cristiane Regina Coelho, Santos Aurélio Grimble Izumi Gonçalves dos, Oliveira Tatiane Flávia de, Porto Alessandra Beggiato, Okazaki Victor Hugo Alves. Efeito da restrição espacial do ambiente na preferência manual em tarefa de alcance em adultos jovens. Rev. Bras. Ciênc. Esporte [Internet]. 2015 Dec

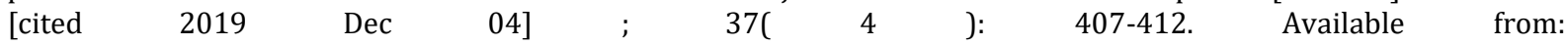
http://www.scielo.br/scielo.php?script=sci_arttext\&pid=S010132892015000400407\&lng=en. http://dx.doi.org/10.1016/j.rbce.2015.08.007.

[2] Hepper, P. G., McCartney, G. R., \& Shannon, E. A. (1998). Lateralised behaviour in the first trimester human foetuses. Neuropsychologia, 36, 531-534. 
[3] Hepper, P. G., Wells, D. L., \& Lynch, C. (2005). Prenatal thumb sucking is related to postnatal handedness. Neuropsychologia, 43, 313-315.

[4] Souza, Rosana Machado de, \& Teixeira, Luis Augusto. (2011). Sobre a relação entre filogenia e ontogenia no desenvolvimento da lateralidade na infância. Psicologia: Reflexão e Crítica, 24(1), 6270. https://dx.doi.org/10.1590/S0102-79722011000100008

[5] Freitas Cidália, Botelho Manuel, Vasconcelos Olga. Preferência lateral e coordenação motora. Motri. [Internet]. 2014 Jun [citado 2019 Dez 04] ; $10(2$ ): 11-24. Disponível em: http://www.scielo.mec.pt/scielo.php?script=sci_arttext\&pid=S1646-

107X2014000200003\&lng=pt. http://dx.doi.org/10.6063/motricidade.10(2).1245.

[6] Lucena, Neide Maria Gomes de et al. Lateralidade manual, ocular e dos membros inferiores e sua relação com déficit de organização espacial em escolares. Estud. psicol. (Campinas) [online]. 2010, vol.27, n.1, pp.03-11. ISSN 0103166X. http://dx.doi.org/10.1590/S0103-166X2010000100001.

[7] Oliveira, Tatiane Flavia de; Baravieira, Evandro; Porto, Alessandra Beggiato; Okazaki, Victor Hugo Alves. Preferência lateral percebida e diagnosticada em adolescentes. Rev. Bras. Ciênc. Esporte [online]. 2016, vol.38, n.4, pp.315-320. ISSN 0101-3289. Disponível em: < http://www.scielo.br/pdf/rbce/v38n4/0101-3289-rbce-38-040315.pdf>.

[8] Oliveira, Gislene de Campos. Avaliação psicomotora à luz da psicologia e da psicopedagogia. 13. ed. Petrópolis, RJ: Vozes, 2014.

[9] Souza, Rosana Machado, Tudella, Eloisa, \& Teixeira, Luis Augusto. (2011). Preferência manual na ação de alcançar em bebês em função da localização espacial do alvo. Psicologia: Reflexão e Crítica, 24(2), 318325. https://dx.doi.org/10.1590/S0102-79722011000200013

[10] Ashton, G. C. (1982). Handedness: An alternative hypothesis. Behavior Genetics, 12(2), 125-147.

[11] 11-Meng, L. (2007). The rate of handedness conversion and related factors in left-handed children. Laterality, $12(2), 131-138$.

[12] 12-Macedo, C. S., Andreucci, L. C., \& Montelli, T. C. B. (2004). Alterações cognitivas em escolares de classe socio-econômica desfavorecida: resultados de intervenção psicopedagógica. Arquivos de Neuro-psiquiatria, 62 (1), 852-857.

[13] 13- Fernandes, Cleonice Terezinha, Dantas, Paulo Moreira Silva, \& Mourão-Carvalhal, Maria Isabel. (2014). Desempenho psicomotor de escolares com dificuldades de aprendizagem em cálculos. Revista Brasileira de Estudos Pedagógicos, 95(239), 112-138. https://dx.doi.org/10.1590/S2176-66812014000100007

[14] 14- Brêtas José Roberto da Silva, Pereira Sônia Regina, Cintra Cintia de Cássia, Amirati Kátia Muniz. Avaliação de funções psicomotoras de crianças entre 6 e 10 anos de idade. Acta paul. enferm. [Internet]. 2005 Dec

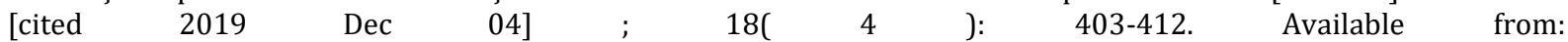
http://www.scielo.br/scielo.php?script=sci_arttext\&pid=S0103-

$21002005000400009 \& \operatorname{lng}=$ en. http://dx.doi.org/10.1590/S0103-21002005000400009. 


\section{Capítulo 23}

\section{Aspectos identitários das primeiras turmas de alunos do campus da Uece de Tauá}

\section{João Álcimo Viana Lima}

Resumo: 0 Centro de Educação, Ciências e Tecnologia da Região dos Inhamuns (CECITEC), integrante da Universidade Estadual do Ceará (UECE), foi fundado em 1995 no âmbito da política de expansão da interiorização universitária. Esta pesquisa teve como objetivo central a análise da constituição e do perfil das primeiras turmas de estudantes do referido Campus. Metodologicamente, recorreu-se a uma abordagem qualitativa, por meio da associação entre três tipos de pesquisa: bibliográfica, documental e de campo (levantamento). Em torno deste, optou-se, preferencialmente, à entrevista como técnica de interrogação, tendo como sujeitos os discentes que compuseram as turmas inaugurais dos primeiros cursos implantados: Ciências e Pedagogia. Quanto ao referencial teórico, a pesquisa recorreu a diversos autores, como: Petrola (1993), Cartibani (2003), Lima (2003); Zabalza (2004), Silva (2011) e Araújo e Lima (2005). Em termos de resultados, verificou-se que os primeiros alunos do Campus da UECE de Tauá, em face da demanda reprimida na microrregião por cursos universitários, eram detentores de uma média de idade (26,4 anos), bastante superior às turmas das gerações futuras que ingressaram nesta IES (18,8 em 2019). Além disso, outros aspectos compuseram o seu perfil, como as questões gênero na definição da escolha dos cursos (predominância de 100\% de matrícula feminina em Pedagogia e presença majoritariamente masculina em Ciências), a taxa de aprovação nas disciplinas (57,7\% dos que ingressaram em 1995.1 concluíram seus cursos em quatro anos) e o fato de que mais de um terço dos discentes já atuavam à época no magistério.

Palavras-chave: UECE; CECITEC; perfil universitário; primeiros alunos; interiorização universitária. 


\section{INTRODUÇÃO}

O Centro de Educação, Ciências e Tecnologia da Região dos Inhamuns (CECITEC), integrante da Universidade Estadual do Ceará (UECE), foi fundado em 1995 durante a gestão do reitor Paulo de Melo Jorge Filho (Paulo Petrola), no âmbito da política de expansão da interiorização universitária.

Para tanto, houve um conjunto de atividades preliminares, que se revelaram relevantes e/ou necessárias para efetivação da implantação do Campus: a realização do seminário "Os Inhamuns no desenvolvimento do Ceará", em novembro de 1993; a obtenção de sede própria, em Tauá, em abril de 1994; o lançamento oficial do Centro, em setembro de 1994; a criação dos cursos de Ciências e Pedagogia, pelo Conselho de Ensino, Pesquisa e Extensão, em outubro de 1994; a realização de curso pré-vestibular, de outubro a dezembro de 1994; a realização de concurso vestibular, em janeiro de 1995; a realização de concurso de provas e títulos para professores, em março de 1995 (LIMA, 1999).

No decorrer de sua história, o CECITEC tem suscitado debates sobre o seu papel, como instituição universitária, no contexto do desenvolvimento microrregional e, em especial, nos processos educacionais. Destarte, faz-se necessário que se preserve a memória referente às manifestações explicitas e discretas, aos embates políticos e procedimentos administrativos, ao sentimento coletivo e à participação dos múltiplos agentes históricos, que resultaram na conquista dessa obra educacional.

Esta pesquisa teve como objetivo central a análise da constituição e do perfil das primeiras turmas de estudantes do Centro de Educação, Ciências e Tecnologia da Região dos Inhamuns (CECITEC), tendo os seguintes desdobramentos de investigação: levantamento da dimensão socioeconômica dos alunos, incluindo sua inserção ou não no mundo do trabalho na época de seus ingressos na IES; identificação de traços característicos da turma, como a média de idade, índices de evasão e nível de participação nas atividades do Centro, estabelecendo parâmetros comparativos com outras gerações de alunos; análise das razões da opção pelos cursos de graduação disponibilizados, com ênfase para as questões de gênero; estudo do processo de interiorização universitária liderado pela UECE.

Para a fundamentação teórica das questões relacionadas ao objeto de estudo e análise dos fenômenos a ele subjacentes, recorreu-se a um conjunto de autores, tais como: Petrola (1993), Cartibani (2003), Lima (2003), no estudo sobre a dimensão histórica e o papel das universidades e acerca da interiorização universitária; Zabalza (2004), Silva (2011) e Ristoff (jul./dez. 2013) na análise dos perfis dos estudantes universitários; Petrola (1993), Lima (1999) e Araújo e Lima (2005), no aprofundamento da política de interiorização da UECE e do processo de fundação da referida Unidade Acadêmica; Mesquita (out. 2003), na compreensão dos movimentos protagonizados e/ou apoiados por estudantes universitários.

\section{METODOLOGIA}

Em termos metodológicos, recorreu-se a uma abordagem qualitativa, por meio da associação entre três tipos de pesquisa: bibliográfica, documental e de campo (levantamento). Destarte, utilizou-se como material para consulta, publicações periódicas, avulsas e diversas (fontes bibliográficas); documentos oficiais, publicações administrativas e registros iconográficos (fontes documentais).

Além disso, foi realizado um levantamento de informações e opiniões, recorrendo-se, preferencialmente, à entrevista como técnica de interrogação. Todavia, em face de sua impossibilidade em alguns casos, fez-se o uso, também, de questionários com perguntas abertas. Adotou-se a forma parcialmente estruturada, que se guia "por pontos de interesse" que o pesquisador/entrevistador vai explorando no decorrer de seu uso (BARBOSA, 2001, p. 255).

Concebendo a relevância da utilização da fonte oral no percurso investigativo, para a escolha dos sujeitos foi considerado o segmento dos discentes que compuseram as turmas inaugurais dos primeiros cursos implantados: Ciências e Pedagogia.

Ressalte-se que a fonte oral, para além de propiciar informações, permite ao pesquisador "entrar no campo da história como um fiscal invisível ajudando a expor os silêncios e as deficiências da documentação escrita e revelar o 'tecido muscular ressecado' que, quase sempre, é tudo o que tem em mãos" (SAMUEL, set. 1989/fev. 1990, p. 237). Alberti acrescenta: “[...] O que fascina numa entrevista é a possibilidade de tornar a vivenciar as experiências do outro, a que se tem acesso sabendo compreender as expressões de sua vivência" (2004, p. 18-19).

Na dimensão temporal, a pesquisa fez um recorte do período que corresponde à gênese institucional da ideia à primeira fase das atividades do CECITEC, ou seja de 1993 a 1995. No entanto, a delimitação do 
tempo para efeito de definição das abordagens centrais não se estabeleceu como impeditiva para ultrapassagem dessa "fronteira", considerando as demandas de contextualizações e de relações entre o tempo demarcado com períodos históricos anteriores e anos posteriores.

\section{RESULTADOS E DISCUSSÃO}

A proposta de implantar uma unidade de ensino superior no Sertão dos Inhamuns surgiu no contexto da política de interiorização universitária da Universidade Estadual do Ceará, que ganhou maior relevo no reitorado do professor Paulo de Melo Jorge Filho (Paulo Petrola), no período de 1992 a 1996.

Paulo Petrola, no âmbito do projeto "Nova UECE", que foi por ele encaminhado ao Governador cearense, em maio de 1992, "traçou diretrizes para a transformação da UECE em uma "Universidade Tecnológica para o Nordeste Semiárido" (PETROLA et al., 1993, p. 39-40). A interiorização universitária, embora possa ser concebida na subjacência do projeto "Nova UECE" e sob a óptica da totalidade institucional, não figura de forma explícita em suas diretrizes. No entanto, Paulo Petrola apresentou uma agenda que estabeleceu 1993 como "o ano do ensino", elencando, entre outras ações, a "solução "dos problemas que afetam o desempenho e a qualidade das Faculdades do Interior, capacitando-as para o melhor cumprimento de seus objetivos pedagógicos em suas respectivas áreas de atuação" (PETROLA et al., 1993, p. 30).

Ancorado no prisma de que uma universidade deve assumir um papel de vanguarda no sentido de se confrontar com os atrasos regionais em suas variadas dimensões, Paulo Petrola asseverou que:

Se não temos, na região, um Curso Superior, toda a juventude, a mais inteligente, a mais brilhante, é coagida, é obrigada, é forçada a emigrar. Vão fazer os cursos noutros locais e não voltam! Com ela vão as riquezas para outras regiões, as quais poderiam ser produzidas equitativamente. Permanecerão os que não têm as mesmas condições físicas, o mesmo ímpeto de vontade, de liderança (Apud UECE, 1995, p. 48-49).

Contribuindo com o debate, Moema Cartibani compreende que: “Quando instalada em determinada região, a instituição universitária ganha contornos socioespaciais pela incorporação do contexto local (econômico, político, cultural e histórico) nas funções que exerce" (2003, p. 3-4). Os "contornos socioespaciais" estão relacionados com o princípio da "liderança", presente desde a gênese da universidade, denotando, com efeito, "a função estratégica concebida para si nos diferentes períodos e em distintas sociedades e culturas” (LIMA, 2003, p. 70).

Considerando o contexto local e sua liderança institucional, na fase que antecedeu o início de funcionamento do Campus de Tauá, a UECE, numa interface entre ensino e extensão, realizou o curso prévestibular, de outubro a dezembro de 1994. Este foi enaltecido por sua qualidade pelos primeiros alunos do CECITEC. Nesse sentido, José Wilton Gonçalves Martins (ex-aluno e primeiro presidente do centro acadêmico de Ciências) enfatiza que:

Foi o melhor cursinho que já foi ofertado para a Região dos Inhamuns. [...] Eu lembro que tinha feito um cursinho em Fortaleza, aproximadamente dois anos antes de acontecer o daqui [...]. Você sabe que esses professores de nome lá em Fortaleza, eram os professores que participavam do cursinho aqui. Nós podemos citar a Vera Lúcia Midéa, que era professora de Redação, o Hipólito [Peixoto], de Matemática, o Jadir [Jucá], da Química. Assim qualquer um dos nossos colegas quando conversávamos sobre esse cursinho sempre comentávamos a importância que ele teve (Apud ARAÚJO; LIMA, 2005).

Referido "cursinho" atendeu a um público de 505 alunos, assim distribuídos de acordo com os municípios em que residiam: Tauá (346), Aiuaba (27), Arneiroz (2), Catarina (45), Parambu (63) e Quiterianópolis (22). Cabe enfatizar que para os estudantes provenientes dos municípios fora da sede do CECITEC, as prefeituras contribuíram com o apoio do transporte para seus deslocamentos.

Pode-se inferir que o curso pré-vestibular conseguiu catalisar três fatores que se revelaram necessários para o êxito do projeto: a mobilização, a motivação e a preparação do público alvo (possíveis candidatos a ingressarem nos cursos de graduação). A fala de José Wilton Gonçalves Martins acerca da qualidade das aulas preparatórias para o vestibular ratifica a versão de publicações jornalísticas (UECE, out. 1994; FOLHA DOS INHAMUNS, nov. 1994) e de documentos da própria Universidade (UECE, 1995; UECE, 14 ago. 1995). 
Para se ter uma melhor dimensão de seu impacto, dos 89 vestibulandos aprovados para a formação das primeiras turmas de universitários, 69 (ou seja, 77,53\%) fizeram o aludido curso preparatório. Em se tratando de um vestibular eliminatório, cuja aprovação exigia pelo menos $30 \%$ de acertos em cada prova, essa etapa preparatória caracterizou-se como estratégica, principalmente, considerando que em face da existência de uma "demanda reprimida", muitos dos possíveis vestibulandos tinham concluído o ensino médio há vários anos.

A demanda reprimida está refletida na média de idade dos primeiros alunos do CECITEC. De acordo com o levantamento realizado por seu controle acadêmico, a idade média dos 87 alunos matriculados, em janeiro de 1995, era de 26,4 anos. Essa realidade foi bastante alterada 24 anos depois, haja vista que em janeiro de 2019, os 77 calouros tinham em média 18,8 anos.

A criação de uma unidade acadêmica na microrregião dos Inhamuns (no sudoeste cearense) processou-se, com efeito, sob a óptica da importância da descentralização da Universidade, com impactos na ampliação das oportunidades e na formação em nível superior daqueles que não têm condições financeiras de se deslocarem para outros centros urbanos. 0 CECITEC constituiu-se, portanto, como a primeira instituição de ensino superior implantada na aludida circunscrição.

Maria Lúcia Oliveira Chaves e Maria da Penha Oliveira Chaves (ex-alunas do CECITEC), ratificam que "antes da criação do Cecitec, um curso universitário era privilégio de pessoas com renda elevada que podiam colocar seus filhos nos grandes centros" (1 jun. 1997, p. 4). Em que pese ao fato de, nas últimas duas décadas e, principalmente, a partir de meados da primeira década do século XXI, ter havido uma significativa ampliação de cursos superiores públicos e privados no País, Ristoff constata que: “[...] persiste uma expressiva distorção de natureza socioeconômica no campus brasileiro, pois há nele 18\% a menos de pessoas da faixa de renda mais baixa do que na sociedade" (jul./dez. 2013, p. 12).

Um conjunto de fatos, como a obtenção da sede própria, a solenidade oficial de implantação, a realização do curso pré-vestibular e o lançamento do edital para o vestibular, foi determinante para a credibilidade do projeto de implantação do CECITEC, na ambiência interna e externa. Tratavam-se de sinalizações concretas de que o Campus de Tauá passaria da idealização para o estágio da concretude.

O vestibular 1995.1, em Tauá, registrou um número de 277 inscritos para as 160 vagas ofertadas, ficando a concorrência em 1,73 candidatos por vaga. As vagas foram assim distribuídas: 40 para Pedagogia (manhã), 40 para Ciências (manhã), 40 para Pedagogia (noite) e 40 para Ciências (noite) (UECE, 14 ago. 1995).

Em seguida, foram aprovados 89 vestibulandos, sendo 13 para Pedagogia (manhã), 16 para Ciências (manhã), 25 para Pedagogia (noite) e 35 para Ciências (noite). Embora o índice de aprovação na proporção dos inscritos tenha ficado em 32,13\%, o jornalista Rubens Frota, à época, fez o seguinte comentário: "Uma tristeza o resultado do vestibular realizado em janeiro último [...] no campus avançado dos Inhamuns. 0 nível dos candidatos e o número de inscritos foi tão pequeno que não preencheram as vagas [...]" (8 fev. 1995, p. 11/A). Por outro lado, a UECE (1995, p.17) justificou que esse número de inscritos não foi maior "por incapacidade das escolas de $2^{\circ}$ grau de fornecerem, em tempo, os documentos exigidos".

Cabe frisar que, para além de Tauá, o não preenchimento da totalidade das vagas ofertadas por vários cursos nos vestibulares na década de 1990 ou, mais ainda, a grande quantidade de vagas que ficavam ociosas, tratava-se de uma questão sintomática decorrente de vários fatores, incluindo a questionável qualidade do ensino na educação básica.

Outro aspecto que requer atenção é o fato de ter havido uma maior concentração de inscritos e aprovados nas vagas ofertadas para o turno noturno. Ao todo, foram inscritos 101 (36,46\% do total) candidatos para os cursos no horário matutino, enquanto 176 (63,54\% do total) concorreram para os cursos noturnos. Entre os aprovados, 29 (32,58\% do total) foram das turmas matutinas e $60(67,42 \%)$ das turmas cujo funcionamento foi ofertado à noite. Ou seja, cerca de dois terços dos inscritos e aprovados optaram pelo horário noturno. Trata-se de um sintoma histórico da educação superior brasileira, que representa a realidade de muitos universitários que já iniciaram sua vida laboral ou estão em busca de um ofício. No caso específico do CECITEC, constatou-se no semestre de ingresso que um percentual expressivo $(37,9 \%)$ de seus primeiros universitários já trabalhava na docência da educação básica, com seus expedientes sendo cumpridos, para a grande maioria, no período diurno. Esse percentual foi elevado para mais de $80 \%$ entre os que se graduaram em fevereiro de 1999 (LIMA, 1999, p. 58). 
Mais de dez anos após a criação do Centro em tela, Ristoff destaca que de acordo com os dados do Questionário Socioeconômico (QSE) do Exame Nacional de Desempenho de Estudantes (Enade), do ciclo 2007, 2008 e 2009, “56\% dos estudantes brasileiros trabalham e estudam” (jul./dez. 2003, p. 17).

Sobre a opção por um dos cursos, Maria Lourdes Nonato dos Santos (ex-aluna) justifica que preferiu o curso de Pedagogia, porque "já tinha experiência no magistério e queria se aprimorar tanto no sentido profissional como pessoal” (Apud ARAÚJO; LIMA, 2005). Muito embora, haja casos em que a opção por Pedagogia tenha se realizado por falta de outras ofertas, há depoimentos de alunos de que na medida em que cursaram as primeiras unidades curriculares foram gradativamente se identificando com o curso. Assim relata Amélia Lira de Farias (ex-aluna):

Eu concorri para o curso de Pedagogia. Inicialmente eu participei desse curso porque Ciências não tinha nada a ver comigo e, Pedagogia, também assim no começo, foi falta de opção, mas com o desenrolar do processo, com a continuação dos estudos eu vi que só tinha a ver, que eu tinha escolhido um curso muito bom e por sinal eu me sinto muito gratificada por ter feito essa escolha (Apud ARAÚJO; LIMA, 2005).

Em torno dos vestibulandos que optaram pelo curso de Ciências, segundo os depoimentos, predominou, também, a existência de uma maior identificação por parte deles com as áreas de Matemática, Física, Química e Biologia, quando postas em comparação com a licenciatura de Pedagogia. Seguindo essa linha de raciocínio, observemos o depoimento de José Wilton Gonçalves Martins:

Concorri para o curso de Ciências tendo em vista a questão de ser uma área mais ligada à parte exata, à Matemática, à Física, à Química e, principalmente, à Biologia, que era a minha atração maior. [...] Então eu nem tive dúvida quando foi para fazer a escolha. Claro tenho admiração, vejo a importância do curso de Pedagogia; no entanto, não tive nenhuma dúvida em fazer a minha escolha por Ciências. Porque assim eu acho que é muito de cada pessoa, eu me identifico bem mais com a área de Ciências (Apud ARAÚJO; LIMA, 2005).

Recorrendo a Zabalza (2004), a "adultez" como traço peculiar dos estudantes universitários, não obstante as limitações impostas pelas estruturas disponibilizadas e pelas condições socioeconômicas, favorece esse processo de escolha e as decisões tomadas no percurso de sua formação acadêmica.

Convergindo com a dissertação de mestrado de Kelly da Silva (2011), na qual ela investiga as relações de gênero no âmbito do curso de Pedagogia, este, em Tauá, registrou, em seu primeiro vestibular, 100\% entre os aprovados e 95,27\% entre os inscritos de predominância feminina. Suscitando a questão:

[...] sabemos que, historicamente, as mulheres são maioria no curso de Pedagogia e, por isso, a trajetória de construção social do magistério enquanto profissão pensada para mulheres necessita ser questionada. Em minha turma de Pedagogia na Universidade Federal de Viçosa (2003), por exemplo, composta por 60 estudantes, 57 eram mulheres; com isso este questionamento tem um porquê (SILVA, 2011, p. 29).

A profissão docente permitiu às mulheres o acesso a um dos espaços públicos anteriormente frequentado pelos homens. No entanto, essa profissão vai ser representada como similar ao trabalho no lar: o cuidar das crianças. Essa concepção é utilizada para naturalizar/reforçar o magistério, especialmente das séries iniciais, como uma profissão feminina (SILVA, 2011, p. 34).

Nos depoimentos das ex-alunas, foi destacada a convivência respeitosa e colaborativa entre os dois cursos, mas que o universo exclusivamente feminino da primeira turma de Pedagogia suscitou-lhes brincadeiras com a rotulação de "florzinhas", consideradas amigáveis por parte das entrevistadas. No âmago desse rótulo está também a compreensão, naturalizada no percurso histórico, de que o referido curso tem um perfil eminentemente feminino. Por outro lado, verificou-se na primeira turma de Ciências, que de seus 51 alunos aprovados no vestibular, a maioria era do sexo masculino $(56,86 \%)$.

Outro traço de identificação da turma pioneira em pauta foi o nível de participação da maioria dos alunos com as ações do Centro recém-implantado. Ao ser concebido como um segmento estratégico, diretamente interessado e como força endógena para se associar em diversas ações na fase de instalação e etapas posteriores do CECITEC, o corpo discente foi receptivo ao chamamento da direção e teve participação 
destacada e colaborativa. A propósito, em 1995 foram realizadas várias reuniões entre o titular do Campus e os representantes do incipiente movimento estudantil (UECE, dez. 1995).

Vê-se, portanto, a face do movimento estudantil (M.E.), que, sem perder a visão do contexto sociopolítico, se envolve diretamente em pautas locais relacionadas a interesses educacionais. A deflagração de lutas em microespaços não imprime ao M.E. um perfil de reducionismo, mas caracteriza sua natureza pluralista subjacente à sua história. Nesse sentido, Mesquita comenta que este "não se limita a suas organizações estudantis e formais, mas se manifesta na própria dinâmica de criação de interesses e pautas", que "pode ser capaz de mobilizar os estudantes" (out. 2003, p. 120).

Outra questão que merece consideração foi abordada por Fonteles: "Os problemas relacionados à repetência e à evasão escolar vêm declinando, sobretudo nas licenciaturas [...] Consequentemente, a redução desses índices vem garantindo um aumento de $20 \%$ do total de graduados pela UECE a cada semestre" (fev. 1999, p. 3). No caso específico do CECITEC, dos 87 alunos matriculados em 1995.1, não houve evasão durante o primeiro semestre, enquanto no quarto período o índice ficou abaixo de $10 \%$ (TRIBUNA DO CEARÁ, 19 jun. 1997).

0 índice de permanência dos alunos, somado à reduzida taxa de reprovação, repercutiram diretamente na primeira solenidade de colação de grau do Centro, realizada em 26 de fevereiro de 1999, que registrou a quantidade de 50 concludentes, o que representa $57,47 \%$ dos que haviam se matriculado quatro anos atrás.

\section{CONSIDERAÇõES FINAIS}

Verificou-se na pesquisa que os primeiros alunos do Campus da UECE de Tauá, em face da demanda reprimida na microrregião por cursos universitários, eram detentores de uma média de idade superior às turmas das gerações futuras que ingressaram nesta IES. Além desse aspecto, outros traços identitários, como as questões de gênero na definição da escolha dos cursos, a elevada taxa de aprovação nas disciplinas e o fato de parte significativa dos discentes já atuarem à época no magistério, compuseram o seu perfil.

O CECITEC, a partir de sua turma pioneira, consolidou sua atuação na formação de professores, com oferta continuada e com repercussão constatada nas redes de ensino de sua área de abrangência (o Sertão dos Inhamuns). No entanto, há outras inserções e contribuições do CECITEC, que se coadunam com os valores históricos/universais e a missão regional da Universidade, por meio de suas atividades de ensino, pesquisa e extensão, no campo administrativo e na colaboração técnica exercida em suas parcerias com outras instituições públicas e órgãos não governamentais. Evidencia-se, com efeito, a relação entre a dimensão "universal" e a "regional" (MARTINS FILHO, 1966) e o espírito plural da instituição universitária (CHAUÍ, 2 sem. 1993).

\section{REFERÊNCIAS}

[1] Alberti, V. Ouvir contar: textos em História Oral. Rio de Janeiro: Fgv, 2004. 196p.

[2] Araújo, A. A.; Lima, J. Á. V. O processo de criação do Cecitec no âmbito da política de interiorização da Universidade Estadual do Ceará. Tauá, CE, 2005. 96. (Relatório de projeto de pesquisa).

[3] Barbosa, A. P. L. Metodologia da pesquisa científica. Fortaleza: UECE, 2001. 462p.

[4] Cartibani, M. Universidade e Região: O papel das universidades estaduais da Bahia. In: XV Encontro de Pesquisa Educacional do Norte e Nordeste. São Luís: UFMA, 2003. p. 3-4.

[5] Chauí, M. Vocação política e vocação científica da universidade. Educação Brasileira - Revista do CRUB, Brasília, v. 15, n. 31, p. 11-26, 2. sem. 1993.

[6] Chaves, M. L. O.; Chaves, M. P. O. Cecitec: um referencial nos Inhamuns. O Povo, Fortaleza, 1 jan. 1997. Jornal do Leitor, p. 4.

[7] Fonteles, M. C. A política de interiorização da UECE. O Kinamuiú, Tauá, CE, p. 3, fev. 1999.

[8] Folha Dos Inhamuns. Universidade chega aos Inhamuns. Tauá, CE, nov. 1994, p. 1, 9.

[9] Frota, R. Uma tristeza o resultado... O Povo, Fortaleza, 8 fev. 1995. Coluna O Povo nos Municípios, p. 11/A.

[10] Lima, J. Á. V. Gestão acadêmica na UECE e interiorização: a experiência do CECITEC. 1999, 102f. Monografia (Especialização em Gestão Escolar) - UECE, Tauá, CE, 1999. 
[11] ___ Gestão e autonomia universitária: a experiência da UECE. Fortaleza: UECE, 2003. 216p.

[12] Martins Filho, A. O Universal pelo Regional. 2. ed. Fortaleza: Imprensa Universitária, 1966. 332p.

[13] Mesquita, M. R. Movimento estudantil brasileiro: Práticas militantes na ótica dos novos movimentos sociais. Revista Crítica de Ciências Sociais, n. 66, p. 117-149, out. 2003. Disponível em: <https://docero.com.br/doc/sexce8>. Acesso em: 13 fev. 2019.

[14] Petrola, P. Diretrizes para transformação da UECE numa Universidade Tecnológica. In: Universidade Tecnológica para Nordeste Semiárido: Projeto Nova UECE. Fortaleza: UECE, 1993. p. 33-50.

[15] Ristoff, D. I. Perfil socioeconômico do estudante de graduação: uma análise de dois ciclos completos do Enade (2004 a 2009). Rio de Janeiro: Flacso/Brasil - Cadernos do GEA, n. 4, jul./dez. 2013. 33p.

[16] Samuel, R. História local e História oral. Revista Brasileira de História, São Paulo, v. 9, n. 19, p. 219-243, set. 1989/fev. 1990.

[17] Silva. K. Currículo, gênero e identidade na formação de professores/as. 2011, 195f. Dissertação (Mestrado em Educação) - UFJF, Juiz de Fora, MG, 2011.

[18] Tribuna Do Ceará. UECE - Centro de Tauá registra a menor taxa de evasão. Fortaleza, 19 jun. 1997. Caderno A, p. 11.

[19] UECE. Pré-Universitário da UECE em Tauá. UECE Notícias, Fortaleza, n. 8, out. 1994.

[20] __. Projeto: Centro de Educação, Ciências e Tecnologia - Região dos Inhamuns - Cecitec. Fortaleza, 1995.

[21] __ Cecitec. Of. 068/95-GD. Tauá, CE, 14 ago. 1995.

[22] ___. Cecitec. Relatório de atividades (junho - dezembro / 95). Tauá, CE, dez. 1995. 17p.

[23] Zabalza, M. A. 0 ensino universitário: seu cenário e seus protagonistas. Porto Alegre: Artmed, 2004. 239p. 


\section{Capítulo 24}

\section{Fatores sóciodemográficos do envelhecimento e as universidades da terceira idade}

\section{Vânia Maria Henrique Lima}

Resumo: Ao longo de décadas, a tendência observada de aumento da expectativa de vida e de diminuição da natalidade têm chamado a atenção dos pesquisadores que estudam a evolução do comportamento demográfico entre os países do mundo. 0 presente artigo foi realizado a partir da revisão de literatura que procura trazer à tona elementos referenciais que discutem a idade adulta avançada no contexto da sociedade brasileira e a importância da educação/formação das pessoas ao longo da vida, traçando uma perspectiva sobre o contributo dado pelas Universidades da Terceira Idade na promoção da qualidade de vida. Conclui-se que a (re)formulação de políticas públicas destinadas ao idoso, trazendo junto uma atualização da legislação vigente, são urgentes e absolutamente indispensáveis, justamente levando em consideração que, em grande medida, os idosos constituem um segmento ainda carente de programas específicos e abrangentes o suficiente para um melhor e crescente resguardo da sociedade.

Palavras-chave: Envelhecimento, Universidades, Terceira Idade, Políticas Públicas. 


\section{INTRODUÇÃO}

Ao longo de décadas, notadamente desde o século passado, a tendência observada de aumento da expectativa de vida e de diminuição da natalidade têm chamado a atenção dos pesquisadores que estudam a evolução do comportamento demográfico entre os países do mundo. É visível que nos países em vias de desenvolvimento, o aumento expressivo da população idosa coloca a exigência de intervenções públicas mais significativas e direcionadas, pois são grandes os desafios provocados por mudanças na longevidade da população, implicado em uma agenda que impõe a necessidade de ajustes e mudanças na legislação e na formulação de políticas públicas dirigidas para esse segmento com cada vez mais expressividade e com demandas que lhe são peculiares.

Contudo, a terceira idade ainda suscita um entendimento associado à fragilidade física, atribuindo à velhice alguns estereótipos negativos que remetem a tratamentos como decadência física, incapazes, dependentes físicos e economicamente, senilidade, improdutividade e ausência de papéis sociais, assumidos como características inerentes à velhice, inclusive por pessoas que atingiram essa faixa etária. Assim, frequentemente, enfrentam dificuldades advindas de um processo de envelhecimento que sobrevém de forma inadequada, tornando essa etapa da vida mais difícil, muitas vezes, convivendo com o medo de perderem a autonomia, também lidando com os temores da certeza da finitude, nesta fase em que a morte parece mais próxima.

No caso particular do Brasil, as dificuldades enfrentadas pelo segmento de pessoas envelhecidas, hoje presentes em todos os setores da estrutura social brasileira, claramente estão acarretando uma série de consequências sociais, culturais, econômicas, políticas e epidemiológicas, para as quais o país ainda não se mostra devidamente preparado. Na realidade, as políticas sociais brasileiras precisam dispor de mais abrangência e oferecer tratamentos igualitários aos idosos a fim de atenderem à demanda dos problemas relacionados com a exclusão, a vulnerabilidade, a pobreza e o desemprego de cidadãos de todas as idades (NERI, 2014).

\section{ENVELHECIMENTO DEMOGRÁFICO}

Até duas, três décadas atrás, o Brasil era tido como um país de jovens, motivo pelo qual era habitual se dizer e repetir "o futuro está em suas mãos". Na última década, entretanto, ganha maior nitidez a constituição de outra realidade demográfica, ocorrendo isso em tal proporção que inverteu o que configurava a situação anterior, enfim o país deixa de ser predominantemente de jovens.

Em razão da conjugação positiva de fatores relacionados à melhoria das condições socioeconômicas e de progressos no campo da saúde pública, notadamente, houve um aumento da expectativa de vida da população brasileira, de modo que esta vem atingindo faixas etárias cada vez mais elevadas.

Nas décadas de 40, 50 e 60 do século passado, as características demográficas observadas indicavam uma população bastante jovem, isso se devia a ocorrência de altas taxas de fertilidade e ao decréscimo das taxas de mortalidade em função de um maior e crescente controle de doenças que costumavam ser fatais durante a infância e adolescência. A partir das políticas de saúde pública adotadas, verificou-se que o Brasil teve uma primeira fase acentuada de transição demográfica, vindo a mesma associada à diminuição das taxas de mortalidade. Em apenas 20 anos, entre as décadas de 1940 e 1960, o país reduziu pela metade a sua taxa bruta de mortalidade.

Segundo o Instituto Brasileiro de Geografia e Estatística - IBGE (2016, s.p.), a expectativa média de vida ao nascer exibia um indicador de 45,5 anos, em 1940, sendo de 42,9 anos, se do sexo masculino, e de 48,3 anos no caso do sexo feminino. Desde então, no decorrer das décadas, deu-se um salto extraordinário até alcançar 73,4 anos, em 2010, devendo chegar a 84,3 anos em 2100.

Também nas décadas mais recentes, apontam as estatísticas veiculadas pelo Banco Mundial, tomando dados da Organização Mundial da Saúde [OMS], houve aumento expressivo em relação à expectativa de vida por ocasião do nascimento, de modo tal que, em 28 anos, de 1980 a 2008, ocorreu um aumento de 10 anos desse indicador, que evoluiu de 62,7 para 72,8 anos. Adotando como base o ano de 2016, as estimativas realizadas apontam que para o ano de 2030, portanto passados mais 14 anos, os idosos serão 41,5 milhões, $18 \%$ do total da população. Para 2050 , as estimativas previstas demarcam uma participação de $29,3 \%$ de idosos, o equivalente a 66,5 milhões de pessoas (LEAL, 2016). 
Como visto, essa mudança vem ocorrendo em ritmo acelerado na estrutura populacional brasileira, configurando um crescimento exponencial da população de 60 anos ou mais de idade. De fato, o ritmo do envelhecimento populacional no Brasil se apresenta significativamente maior do que o ocorrido em sociedades mais avançadas durante o século passado. Quando comparado à França, por exemplo, este país levou 145 anos para duplicar a proporção de idosos em sua população, passando do equivalente a 10\%, em 1850, para chegar a 20\%, em 1995.

No que se refere à longevidade, pode-se identificar que houve um "aumento da esperança de vida para ambos os sexos, passando de 70,5 anos em 2000 para 73,2 em 2009. No mesmo período, os homens passaram de 66,7 anos para 69,4 anos, enquanto as mulheres avançaram de 74,4 anos para 77 anos. A diferença de cerca de 7,5 anos se manteve na última década, favorecendo as mulheres" (ALVES; CAVENAGHI, 2013).

Existe uma preocupação em relação a esse descompasso, uma vez que o mesmo tendo continuidade a sociedade brasileira passará por um grande desequilíbrio demográfico futuro. Para alguns estudiosos esse desequilíbrio já vem acontecendo, é o que se denomina de "Pirâmide da Solidão", sendo que no caso específico a quantidade de mulheres sozinhas será maior do que a dos homens com o passar dos anos.

Assim sendo, é preciso que se tomem medidas destinadas a reverter esse quadro atual de tendência ao desequilíbrio demográfico do país, de imediato concebendo a formulação de políticas públicas que atendam à transformação do modelo educacional brasileiro, no sentido de estimular o desenvolvimento de uma cultura de paz na sociedade, na origem envolvendo crianças e adolescente, de modo a provocar, em médio prazo, mudanças na postura da juventude com desestímulo a comportamentos agressivos, tendo em conta que esse segmento é o mais atingido pela escalada de morte por homicídio.

\subsection{ENVELHECIMENTO E VELHICE}

Ao longo da história, o Homem sempre tem se mantido disposto a entender para reverter o processo de envelhecimento. Os alquimistas se mostravam interessados na descoberta de fórmulas mágicas que propiciassem o rejuvenescimento, uma ansiedade que sempre tem acompanhado a trajetória de desenvolvimento das sociedades. 0 "elixir da vida", o desejo da eterna juventude, se renova e permanece até nossos dias, constituindo-se em um dos principais temas de interesse científico, social e econômico.

No entanto, a realidade se nos apresenta de forma intransigente, visto que o envelhecimento é, de fato, um processo complexo que se impõe de modo natural, irreversível, progressivo e inevitável, submetendo todos os seres humanos e sendo caracterizado por um conjunto de fatores fisiológicos, psicológicos e sociais.

O envelhecimento é um processo que se apresenta como inseparável da condição humana e acontece desde o nascimento. De outro lado, a velhice é o estado do indivíduo em idade avançada sobre o qual incidiu o processo de envelhecer. Messy (1999) coloca bem essa distinção entre velhice e envelhecimento.

Se o envelhecimento é o tempo da idade que avança, a velhice é o da idade avançada, entenda-se, em direção a morte. No discurso atual, a palavra envelhecimento é quase sempre usada num sentido restritivo e em lugar da velhice. A sinonímia dessas palavras denuncia a denegação de um processo irreversível que diz respeito a todos nós, do recém-nascido ao ancião. (p.23)

O envelhecimento é caracterizado como um processo natural, mas também é complexo e universal, que depende de vários fatores como: hereditariedade, estatuto econômico (a renda, o trabalho e a proteção social), a pertença ou não a países industrializados, localização geográfica além de aspectos culturais, etc. (LIMA, 2002).

A rigor há fatores que podem interferir diretamente no envelhecimento, como o estilo de vida cultivado que pode desenvolver no indivíduo uma postura ativa. Por outro lado, há perdas e limitações que podem advir com o envelhecimento, mas este é também visto como uma fase de maior maturidade e experiência de vida. Assim, as experiências e os saberes acrescidos ao longo dos anos, podem ser vistos e cogitados como proveitosos, sem dúvida devendo ser otimizados em favor do próprio individuo, de tal maneira que o processo de envelhecimento deverá ser assimilado e reconhecido pelos ganhos e não somente pelas perdas. 


\subsection{MITOS E ESTEREÓTIPOS EM RELAÇÃO À VELHICE}

As pessoas não envelhecem a um mesmo ritmo, mas cabe a pergunta: Por que as pessoas de um modo geral têm tanto medo de envelhecer? Segundo Morillo (2017), as pessoas costumam associar a pessoa "velha" ao imaginário construído desde cedo pelos contos de fada, nos quais a "velha" é comparada a uma bruxa. Quem é a bruxa? Uma velha... queixo grande... nariz comprido...com mão de artrose. Então a figura da bruxa é a figura da velha. "A sociedade não gosta fisicamente da velhice, a velhice é mais próxima da morte."

Muito frequentemente as imagens da velhice estão relacionadas unicamente às mudanças físicas externas, expondo o envelhecimento apenas como um período de perdas e limitações, justamente pelo fato de no envelhecimento patológico os aspectos negativos tenderem a surgir.

No entanto, existem preconceitos positivos como: "Todos os idosos são sábios e experientes", neste caso cria-se uma falsa expectativa que pode muito bem gerar frustrações. Na realidade, em geral, a imagem do idoso nas sociedades modernas é marcada pela decadência física e a ausência de papéis.

A discriminação estereotipada, assumida em função da idade, foi originalmente definida por Butler, em 1969, como "Ageism" (Idadismo) com o significado de discriminação com base na idade. Esse conceito foi apresentado por Butler durante a realização da 1a Assembleia Mundial sobre o Envelhecimento, organizada no ano de 1982, em Viena, referindo-se aos estereótipos e às atitudes negativas a respeito do envelhecimento e dos idosos. Ao identificar os estereótipos, entende-se que a sociedade vê a velhice como uma doença incurável, uma decadência inevitável, desse modo termina associando a velhice a doenças, havendo crenças baseadas em processos de supergeneralização e supersimplificação que conduzem a preconceitos e a estereótipos.

0 processo de envelhecimento, na medida em que está sendo assimilado como etapa importante no desenvolvimento das pessoas, como conquista irreversível das sociedades contemporâneas, vem provocando a superação de paradigmas arraigados em preconceitos, abrindo espaço para a queda de estereótipos comuns que desvalorizavam as pessoas idosas.

Contudo, a desinformação das pessoas sobre os fatos inerentes à velhice evita a mudança de atitudes, de comportamentos enaltecendo determinadas crenças que tendem a relegar a pessoa idosa à margem da sociedade. Crenças e preconceitos socialmente prejudiciais por impedirem, muitas vezes, o aproveitamento das potencialidades dos idosos, de forma a aproveitá-las para que sejam úteis ao bem comum.

Ainda é visível que na sociedade brasileira se fortalece através da mídia o culto da juventude. Com o aumento da longevidade, os indivíduos estão envelhecendo, mas ao mesmo tempo eles não querem ficar velhos, envelhecer distancia o Homem do ideal concebido.

\subsection{APRENDENDO NA TERCEIRA IDADE}

As evidências são de que o interesse da pessoa idosa pela aprendizagem remete a uma postura estimuladora do prolongamento de uma mente ativa, capaz de resguardar seu papel interativo no ambiente social no qual convive, isso em dimensão suficiente para preservar a sua autonomia, a participação nas dinâmicas de uma sociedade em transformação, mantendo o necessário exercício da cidadania.

A aprendizagem é um processo pessoal de caráter vivencial, sendo a pessoa o centro enquanto ser que pensa, sente e vive. Mas o que leva uma pessoa idosa a se dispor a voltar aos estudos? Provavelmente, já não é mais para competir no mercado de trabalho.

Por suposto, o interesse da pessoa idosa na retomada da aprendizagem está associado em buscar manter a mente aberta ao novo, em ocupar bem o tempo disponível para ter uma melhor qualidade de vida, especialmente visando conservar o componente cognitivo sempre ativo para que possa ter independência e autonomia. Estes são atributos imediatos das Universidades da Terceira Idade, objetivando evitar o isolamento e promover a integração dos idosos com as gerações mais novas, favorecendo a troca de saberes que elevem sua autoestima, ao lado de um melhor relacionamento com as pessoas pertencentes à mesma faixa de idade, incorporando e ampliando conhecimentos como forma de desenvolver habilidades e encontrar prazer em viver. 
A educação na Terceira Idade teve sua origem na tentativa de alfabetizar pequenos grupos que não tiveram a oportunidade de aprender a ler e escrever. Atualmente, a educação para a Terceira Idade tem um matiz muito diferente, como regra não se investe na alfabetização, senão no ensino de conhecimentos especializados dados por professores universitários.

Vários são os motivos dos idosos desejarem voltar a estudar, por certo a obtenção de um certificado não será o principal interesse, mas sim conhecer novas pessoas com outras perspectivas de vida e outras formas de encarar situações, fugir da solidão e do abandono dos familiares que trabalham fora de casa, praticar atividades físicas para afastar algumas doenças por causa da imobilidade, tudo isto com um firme propósito: começar a ter uma vida ativa e participativa, podendo ser útil e importante para outras pessoas e não somente no âmbito do seu núcleo familiar.

O inexorável aumento da utilização da internet para cobrir todas as finalidades econômicas e relações sociais, ao lado do crescimento do número de pessoas idosas em todos os países, são fenômenos da contemporaneidade. O uso da Tecnologia da Informação e da Comunicação [TIC], (e.g. computador, notebook, telefone celular, smartphone, tablet), desde o final do século XX e início do século XXI se tornou uma constante em quase todas as sociedades, contudo muitas pessoas da terceira idade ainda rejeitam o uso da tecnologia por se acharem incapazes de aprender, enfim, sentem receio, têm medo e criam certa resistência em aprender a usar a informática, por acreditarem que vão manusear o computador erroneamente ou que venham a danificá-lo.

De fato, muitos idosos estão exclusos da era digital, diante das gerações mais novas familiarizadas com o uso da internet, assim os idosos necessariamente precisam passar por um processo de adaptação às novas tecnologias.

Contudo, pouco a pouco, o acesso aos recursos proporcionados pelas tecnologias digitais começa a fazer parte do dia a dia das pessoas da terceira idade, visto que muitos serviços estão disponíveis somente por meio da internet. Dessa forma, os idosos que ainda não fazem uso dessas tecnologias, terminam excluídos de importantes serviços.

A exigência está definitivamente posta, tendo em conta que o acesso à internet não se dá apenas para a pesquisa, mas para fazer amizades, compras virtuais, trocar informações, pagamento de contas, além de disponibilizar serviços sem a necessidade de sair de casa, o que facilita a vida do idoso e possibilita uma maior interação sua com o mundo. Além de inevitável, "o uso das tecnologias pode fazer com que idosos trabalhem melhor a região da memória e tomada de decisões, além de ser uma importante aliada para que o idoso não perca a capacidade de raciocínio". (BRITO, 2017)

Entretanto, o uso da moderna tecnologia digital tem implicações não unicamente de ordem positiva, mas também negativa se inapropriadamente usada. 0 aspecto tido como positivo é por favorecer a ativação da memória e estimular o poder de concentração na terceira idade.

O lado negativo está ligado a situações de uso excessivo do computador, comportamento este que dá origem a doenças que atingem músculos, tendões e nervos dos membros superiores: dedos, mãos, punhos, antebraços, braços, ombros e pescoço, as denominamos Lesões por Esforços Repetitivos [L.E.R.] ${ }^{1}$.

0 interesse dos idosos pela aprendizagem no uso da informática tem se tornado cada vez mais comum, algo que favorece a integração dos mesmos na moderna sociedade, com a preservação de seus papéis. Mesmo assim, a Pesquisa Nacional de Amostragem por Domicílio Contínua [PNAD Contínua] - (IBGE, 2018), no tocante aos idosos (60 anos ou mais), aponta que somente $24,7 \%$ acessaram a internet. Esse comportamento foi observado tanto entre os homens como entre as mulheres, sendo que a parcela feminina que acessa a internet superou a masculina em todas as faixas etárias, exceto entre os idosos.

\subsection{CONTRIBUTO DAS UNIVERSIDADES DA TERCEIRA IDADE}

Os programas das Universidades da Terceira Idade, certamente têm como antecedentes históricos as pioneiras experiências e modelos idealizados na França, particularmente nas cidades de Toulouse, em 1973, e em Lyon, no ano de 1975.

\footnotetext{
${ }^{1}$ L.E.R. Lesão causada pelo desempenho de atividade repetitiva e contínua, como tocar piano, dirigir caminhões, fazer crochê, digitação etc.
} 
Vale também aqui mencionar que, no decorrer da década de 70, relativamente à criação de oportunidades educacionais para pessoas idosas, França e Estados Unidos foram os primeiros países que trataram dessa questão, o que guarda coincidência com a intensificação verificada em seus estágios demográficos de envelhecimento populacional.

Na cidade de Toulouse, na França, na década de 1960, surge a primeira iniciativa visando à criação de uma Universidade da Terceira Idade, cumprindo a finalidade de ocupar o tempo livre das pessoas aposentadas, buscando tirar os idosos do isolamento. Diante do clima político de reconstrução da França, em meio ao quadro de dificuldades do Pós II Guerra Mundial, parte da sua população idosa ficou submetida a condições de desassistência, de quase indigência social, situação essa que, em 1962, respondeu pelo empenho em torno da organização de ações direcionadas à integração da velhice na sociedade, mediante a adoção de reformas político-administrativas que contemplavam a cobertura apropriada e o atendimento digno das pessoas idosas.

Nesse contexto, foi criado um novo vocabulário para designar de forma respeitosa a representação dos jovens aposentados, surge então o termo Terceira Idade, que passa a ser sinônimo de envelhecimento ativo. Em 1968, foram criadas as então denominadas Universidades do Tempo Livre, que em geral se dedicavam a oferecer apoio à saúde, ao lado de ações de alfabetização dessa população idosa, principalmente buscando modificar sua imagem perante a sociedade.

Em 1973, pelas mãos do professor Pierre Vellas, destacado estudioso de direito internacional da Universidade de Ciências Sociais de Toulouse, norteado, em suas andanças pelo mundo, por experiências e desafios na promoção de direitos humanos, se deu a criação da Universidade da Terceira Idade "Universitè Du Troisième Âge" [U3A], em parceria com colegas e orientandos de pós-graduação. Em poucas décadas, com efeito, a Universidade da Terceira Idade iria se estabelecer em todo o mundo civilizado.

Pierre Vellas considerou que as oportunidades oferecidas aos idosos eram quase inexistentes, chegando à conclusão de que muitos dos processos patológicos tinham como origem o problema da exclusão social. A partir disso, concluiu que a universidade deveria se abrir a todos os idosos, oferecendo programas intelectuais e artísticos, de lazer e atividades físicas, de forma a tirar os idosos da situação de isolamento e modificar sua imagem diante da sociedade.

A princípio, chegou a pensar que não teria sucesso, mas depois de passados alguns anos existiam cerca de vinte universidades da Terceira Idade na França. A experiência avançou rapidamente para outros países europeus, de tal modo que no início da década de 80 essas universidades já se encontravam presentes na Suíça, Bélgica, Espanha, Itália, Polônia, além terem sido criadas nos Estados Unidos e Canadá.

De maneira especial, a educação para a terceira idade está compreendida no conceito de aprendizagem ao longo da vida, estando mais empenhada em proporcionar para a população idosa uma interação no ambiente social em que vive, onde a troca de experiências é uma mais valia para que se sinta valorizada. Objetivando promover a saúde, o bem-estar psicológico e social, o conceito de educação permanente tem sido defendido desde os anos 60 e 70, havendo uma ênfase na necessidade de ampliação de oportunidades educativas, no sentido de que a educação se prolongue por toda a vida. De todo modo, Canário (2008) faz a seguinte ponderação sobre essa questão ao afirmar:

A Educação de Adultos, tal como é hoje conhecida, é um fenómeno recente, mas não constitui uma novidade. Concebendo a educação como um processo largo e multiforme que se confunde com o processo de vida de cada indivíduo, torna-se evidente que sempre existiu educação de adultos. (CANÁRIO, 2008, p.11)

Primando pelo alinhamento ao conceito de aprendizagem ao longo da vida, bem como atuando em sintonia com os princípios da Gerontologia Educativa, as Universidades da Terceira Idade [UTIs] assumem feitio protagonista, ao romperem, pela exemplaridade, com habituais e anacrônicos paradigmas, recorrendo à adoção de metodologias mais ajustadas ao reconhecimento e valorização dos idosos, por meio de ações que lhes propiciem a assimilação de informações, assim como de iniciativas de formação e aprendizagem, de modo que reúnem programações ofertando um leque de atividades interativas, culturais e científicas.

Antes as pessoas idosas eram geralmente rotuladas como inúteis, vistas como inválidas e, não raro, abandonadas à própria sorte e entregues a doenças. 
Hoje esse quadro vem mudando, as pessoas idosas procuram ter seus espaços como forma de interação e socialização e buscam, assim, a criação de novos hábitos, hobbies e habilidades, espaços em que as Universidades da Terceira Idade se colocam visando combater a exclusão e o isolamento social, além de oferecerem a aquisição de novos conhecimentos e a troca de experiências.

Assim sendo, considerando o conjunto de atividades que podem ser ofertadas a essa população, a literatura sobre a temática reconhece que as experiências acumuladas no decorrer dos anos têm comprovado resultados auspiciosos relacionados ao aumento da autoestima, da autoconfiança e, em consequência, da própria vontade de viver.

Diante dessa perspectiva, foram tirados encaminhamentos da II Assembleia Mundial sobre o Envelhecimento, realizada no ano de 2002, em Madri na Espanha, recomendando o alargamento de práticas objetivando a promoção do envelhecimento ativo, tais como: (i) programas intergeracionais; (ii) Universidades da Terceira Idade; e (c) voluntariado.

No Brasil, nas décadas de 60 e 70, o Serviço Social do Comércio [SESC] foi o primeiro organismo a introduzir um programa com atividades recreativas e culturais voltado para pessoas mais velhas, os chamados Centros de Convivência para Idosos. 0 trabalho social com idosos constituiu um marco inicial da expansão da oferta de serviços voltados ao atendimento comunitário oferecido pelo SESC. Além disso, nos anos 70, o SESC passou a organizar as primeiras Escolas Abertas à Terceira Idade, o que terminou estimulando a criação no país de outras entidades e espaços dispostos a discutir ações educativas no processo de envelhecimento brasileiro.

No ano de 1982, a Universidade Federal de Santa Catarina [UFSC] criou o Núcleo de Estudo de Terceira Idade [NETI], uma iniciativa predecessora na exploração desse tipo de programa que contemplava características inerentes às Universidades da Terceira Idade.

Anos depois, em 1990, a Pontifícia Universidade Católica de Campinas [PUCCAMP] colocou-se como uma das universidades precursoras nessa questão ao abrir um programa baseado nos modelos europeus de valorização dos idosos, focalizando o objetivo de propiciar às pessoas mais velhas um ambiente de aprendizagem em prol da cidadania, segundo a finalidade de estimular a ocupação ativa do tempo livre, realizar estudos e divulgar conhecimentos técnico-científicos na área de gerontologia.

Com a expressividade cada vez maior desse segmento na sociedade, em virtude do aumento da expectativa de vida, a criação desses espaços oportuniza o acesso continuado das pessoas idosas à cultura e à educação, além de outros benefícios que as Universidades da Terceira Idade podem oferecer. Nessa ambiência, as pessoas adultas de idade avançada exercitam a sua capacidade intelectual, bem como trabalham o lado emocional, a estimulação cognitiva e aumentam a sua autoestima, inegavelmente configurando um quadro de reconhecida mais-valia.

Regra geral, as atividades educativas ofertadas são realizadas sem que estejam sujeitas ao regime formal dos cursos regulares, mais atendendo ao propósito de contribuir para a integração social e o bem-estar das pessoas idosas. Todavia, como é comum em qualquer outra etapa da vida, é indispensável não descuidar de manter a necessária motivação. A ideia não é acumular conhecimentos para usar depois, mas sim saber utilizar esse aprendizado para viver melhor e para alcançar uma maior qualidade de vida.

Com efeito, as evidências existentes são as de que as Universidades da Terceira Idade [UTIs] trazem contribuição para atenuar a depressão, evitar a solidão e a sensação de inutilidade, conforme alguns estudos ponderam. A esse respeito, observa Neri (1991, apud POCINHO, SANTOS, PAIS \& PARDO, 2013) que as UTIs resultam em melhora significativa na condição de saúde das pessoas, ao oferecerem uma variedade de atividades que favorecem a motricidade, as funções cognitivas e intelectuais.

Convém lembrar que não chega a ser tão recente que algumas universidades brasileiras veem recepcionando e dando suporte ao oferecimento de atividades educativas voltadas para a população da terceira idade, tomando por referência as concepções teóricas e práticas surgidas na França, precisamente as experiências modelares iniciadas na l'Université des Sciences Sociales de Toulouse, sob a denominação "l'Universitè du Troisième Âge" (Universidade da Terceira Idade), fundada pelo professor Pierre Vellas, em 1973; em seguida, dois anos depois, em1975, no campus da l'Université de Lyon II - Université Lumière, a professora Hélène Reboul, que coordenava o curso de Gerontologia Social, conduziu a organização da l'Université Tous Âge (Universidade de Todas as Idades). 
Correntemente, vale aqui destacar, dentre os objetivos assumidos pelas Universidades da Terceira Idade cumpre o propósito de produzir, organizar e disponibilizar informações sobre o irremediável processo de envelhecimento que atinge o ser humano. No essencial, o que se persegue é internalizar o desenvolvimento de uma nova concepção de velhice, de um lado, buscando afirmar um entendimento atual, capaz de determinar novos comportamentos, os quais dissociem o processo de envelhecimento da solidão, da incapacidade e da dependência dos idosos; de outro, contribuindo com a superação dos preconceitos ainda presentes na sociedade em relação às pessoas idosas, vulgarmente relegadas à condição de seres que pouco ou quase nada podem trazer de socialmente produtivo. Conforme bem salientam Monteiro e Neto (2008, p. 52), a "Universidade da Terceira Idade representa uma estratégia preventiva da solidão ao criar espaços para o lazer e convívio".

Em suas programações, as UTIs oportunizam aos idosos a possibilidade de disporem de uma maior convivência social, através de passeios, jogos e leitura. Há também estímulo quanto à preservação da memória, o cuidar da espiritualidade e em manter a atenção com o próprio corpo. Ao lado disso, promovem pesquisas e organizam informações que favorecem a produção de conhecimentos sobre o processo de envelhecimento, instigando a formação de profissionais que venham atuar nessa área da Terceira Idade. Desde 1975, com a finalidade de auxiliar a atuação dessas universidades, foi criado a International Association of Universities of the Third Age [AIUTA $]^{2}$, com sede na Bélgica, que visa nortear o desenvolvimento das Universidades da Terceira Idade em todo o mundo.

Algumas universidades europeias da terceira idade, devido ao crescente número de pessoas idosas interessadas em participar, passaram a atuar incluindo alunos acima de 45 anos, desde que soubessem ler e escrever, enquanto outras aceitavam pessoas com idade acima de 60 anos com qualquer escolaridade, assim criando oportunidade de educação permanente também para esse segmento, regra geral antes destinada às pessoas mais jovens.

No Brasil o número de universidades voltadas para a terceira idade tem crescido continuamente, da mesma forma que os Centros de Convivência da Terceira Idade, fato este que oferece ampliadas oportunidades para a formação de novas atitudes e comportamentos dos idosos. A literatura que trata dessa temática destaca que os idosos buscam nesses Centros de Convivência formas de socialização e de melhoria da sua autoestima, além da busca de conhecimentos para conseguirem desenvolver uma melhor qualidade de vida.

A educação que é oferecida aos idosos, tem por fim ajudá-los a manter e estimular os níveis normais de desenvolvimento. São espaços para os idosos voltarem a refletir sobre a sua vida e para ampliarem seus objetivos, de modo a se sentirem ativos. Assim sendo, eles não visam ocupar o tempo ocioso e nem aprender conhecimentos que já foram vistos no decorrer dos anos. Debert $(1999$, p. 14) salienta que as "experiências vividas e os saberes acumulados são ganhos e oferecem oportunidades para realizar projetos abandonados em outras etapas e estabelecer relações mais profícuas com o mundo dos mais jovens e dos mais velhos".

Sabidamente, as Universidades da Terceira Idade têm contribuído e influenciado positivamente na vida familiar de seus alunos, visto que em muitos lares o conflito intergeracional existe, ficando os idosos sujeitos a pressões extremas que ocasionam formas diversas de agressões, são exemplos: as físicas, o abandono e a violência por exploração financeira, além de outras nos quais as vítimas são pessoas idosas.

As experiências de atuação já acumuladas demonstram que as Universidades da Terceira Idade [UTIs] propiciam resultados com mudanças significativas na vida das pessoas que delas participam, tais como: o desenvolvimento de atividades recreativas; as novas amizades (que combatem o isolamento); o aumento de seus sentimentos de confiança e utilidade; a aquisição de conhecimentos que possam fomentar a sua capacidade cognitiva e ao mesmo tempo proporciona uma visibilidade maior às pessoas que estão envelhecendo, de forma a colaborar para o desenvolvimento de uma sociedade mais humana.

Não obstante a difusão rápida das experiências provenientes das Universidades da Terceira Idade, do sucesso que essa modalidade de educação permanente para adultos e idosos vem alcançando, em um cenário de expansão do processo de urbanização, ao mesmo tempo de envelhecimento da população, ainda são reduzidas as publicações sobre o alargamento dessas atividades em diversos países (MONTEIRO \& NETO, 2008). 


\section{CONSIDERAÇÕES FINAIS}

O envelhecimento demográfico presenciado no mundo atual é um processo contínuo que leva a humanidade a se defrontar com outro paradigma social, no qual o aumento da longevidade obviamente prenuncia alguns desafios. Ao mesmo tempo em que, de um lado, o sonho de viver mais representa uma inegável conquista, de outro, dado o expressivo crescimento da população idosa, esse novo contexto sociodemográfico remete à necessidade de políticas públicas especificadas, direcionadas para atender às demandas distintas originárias desse segmento populacional, bem como de iniciativas que instrumentalizem a sociedade para, em todas as faixas etárias, mais adequadamente lidar com essa realidade.

\section{REFERÊNCIAS}

[1] Alves, José Eustáquio Diniz; Cavenaghi, Susana Marta. Indicadores de desigualdade de gênero no Brasil. Mediações, v.17, n.2, p. 83-105, 2013.

[2] Brito Albert Marinho de. O uso das tecnologias pode fazer com que os idosos trabalhem melhor a região da memória e tomada de decisões. Informática e a Terceira Idade. Disponível em: https://www.univicosa.com.br/uninoticias/noticias/informatica-e-a-terceira-idade. Acedido em: 26 Mar.2018.

[3] Canário, Rui. Educação de adultos: Um campo e uma problemática. Lisboa: Educa, 2008.

[4] Debert, Guita Grin. A Reivenção da velhice: Socialização e Processos de Reprivatização do Envelhecimento. São Paulo: Fapesp, 1999.

[5] Leal, Luciana Nunes. A população idosa vai triplicar entre 2010 e 2050, aponta a publicação do IBGE. 0 Estado de São Paulo. São Paulo. Disponível em: https://brasil.estadao.com.br/noticias/geral,populacao-idosa-vaitriplicar-entre-2010-e-2050-aponta-publicacao-do-ibge,10000072724. Acedido em: 20 Jun. 2017.

[6] Lima, Nuno Maria de Barros e Cunha Azevedo. Auto-estima e actividade física: Contributo de um programa de actividade física na auto-estima em adultos idosos do Conselho de Coimbra. 2002. 200f. Tese de Mestrado em Ciências do Desporto e Educação Física. Universidade do Porto, 2002. Disponível em: https://docplayer.com.br/56678504-Auto-estima-e-actividade-fisica.html. Acedido em: 20 Jun. 2018

[7] Messy, J. A pessoa idosa não existe. Uma abordagem psicanalítica da velhice. São Paulo: Aleph, 1999.

[8] Monteiro, Helena; Neto, Felix. Universidades da Terceira Idade: Da solidão aos motivos para a sua frequência. Legis Editora. 2008.

[9] Morillo, L. S. (2017). Brasil envelhece e é preciso se preparar cada vez mais cedo. Jornal Nacional. Disponível em: http://g1.globo.com/jornal-nacional/noticia/2017/01/brasil-envelhece-e-e-preciso-se-preparar-cada-vez-maiscedo.html. Acedido em 02 de janeiro de 2017.

[10] Pocinho, Ricardo; Santos, Eduardo; PAIS, Alexandra; Pardo, Esperança Navarro \& Colaboradores. Envelhecer Hoje: Conceitos e práticas. Curitiba: Appris, 2013.

[11] Neri, Anita Liberalesso. Palavras-chave. 4 ed. Campinas: Alínea, 2014 


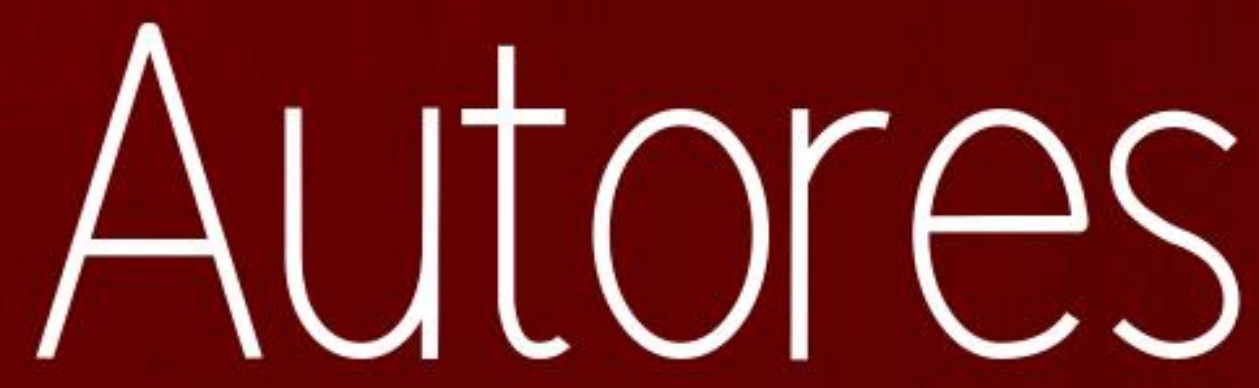




\section{ALESSANDRA DE PAULA}

Doutora em Engenharia de Produção (UFSC), Mestre em Engenharia de Produção e Sistemas ( PUC PR), Especialista em Formação de Docentes e Orientadores Acadêmicos, Especialista em Planejamento e Gestão Estratégica, Especialista em Engenharia de Produção, graduada em Administração. Coordenadora e professora titular do Centro Universitário Internacional UNINTER, com experiência na área de Inteligência Organizacional, Administração da Qualidade, Estratégias Competitivas e Modelos de Gestão e Inovação. Atua desde 2005 na Educação Presencial e na Educação a Distância nos seguintes temas: Gestão e Desenvolvimento de Serviços, Avaliação Organizacional, Gestão e Desenvolvimento de Produtos e Serviços, Estratégias Competitivas, Logística Empresarial, Qualidade Organizacional e Motivacional, Qualidade na Educação a Distância e Gestão e Inovação. Atualmente integra o grupo de Pesquisa: Práticas de ensino e gestão organizacional. Autora de três obras e Referee de congressos como Enegep e Simpep.

\section{ALINE ALBINO QUINTANILHA FAVER}

Especialista em Dermatologia e em Medicina do Trabalho pela Universidade Federal Fluminense. Graduada em Medicina FTESM. Título de Especialista pela AMB/SBD. Membro efetivo da Sociedade Brasileira de Dermatologia. Professora de Dermatologia da Faculdade de Medicina de Petrópolis.

\section{ALINE JOANA ROLINA WOHLMUTH ALVES DOS SANTOS}

Professora associada no Centro de Ciências Químicas, Farmacêuticas e de Alimentos da Universidade Federal de Pelotas - UFPel, ministra aulas de Química Inorgânica para diversos cursos de Graduação e para o Programa de Pós-Graduação em Química, sendo que orienta alunos de graduação, mestrado e doutorado. Coordena projetos de ensino, pesquisa e extensão, sendo: dois projetos de pesquisa na área de química bioinorgânica, envolvendo caracterização estrutural de compostos de coordenação e polímeros biomiméticos; três projetos de extensão universitária intitulados TRANSFERE - Mediação de conhecimentos químicos entre comunidades e universitários, Site do Projeto TRANSFERE e Química no PS - Química no Processo Seletivo; um projeto de ensino intitulado QuiCo - Estratégias de Ensino e Aprendizagem na Química do Cotidiano e colabora no Projeto de Monitorias da UFPel. Possui título de doutor em Química pela Universidade Federal de Santa Maria - UFSM, com área de concentração em Química Inorgânica, sendo que 2,5 anos de doutorado foram realizados na Universidade de Bonn - Alemanha, decorrente do programa de doutorado sanduíche financiado por DAAD-CAPES. Possui mestrado em Química, também na área de concentração em Química Inorgânica e graduação em Farmácia Bioquímica - Análises Clínicas, ambos pela UFSM.

\section{AMANDA MENDES GOMES}

Graduanda em Ciências Biológicas (Licenciatura), na Universidade Estadual do Ceará (UECE). Em 2017, bolsista de Iniciação Científica (PIBIC-CNPq) em um laboratório de Reprodução Animal. Em 2018, bolsista CAPES do Programa Institucional de Bolsas de Iniciação à Docência (PIBID), no Campus de Fortaleza do Instituto Federal de Educação, Ciência e Tecnologia do Ceará (IFCE). Atualmente, trainee da Harpia-Empresa Júnior de Biologia na UECE. Tem experiência na área de Histologia, Embriologia e Educação. Atua nas áreas Laboratórial e de Educação.

\section{AMANDA THAIS PASSOS CORDEIRO CAVALCANTE}

Enfermeira. Especialista em Docência do Ensino Superior. Especialista Enfermagem do Trabalho.

\section{ANA LÍDIA ALENCAR VASCONCELOS}

Graduanda em Engenharia Civil pela Universidade Federal do Cariri - UFCA; Membro do Escritório Habitar, projeto de extensão da Universidade Federal do Cariri - UFCA; Autora de artigos científicos em congressos nacionais. 


\section{ANA MARIA RODRIGUES DOS SANTOS}

Mestre em Psicologia Social pela Universidade Gama Filho, na área de concentração Tecnologias Emergentes, Cognição e Subjetividade, Especialista em Responsabilidade Social e Terceiro Setor pela Universidade Federal do Rio de Janeiro, em Mediação Pedagógica em Educação a Distância pela PUC-Rio e em Educação com aplicação da Informática pela Universidade do Estado do Rio de Janeiro, Graduada em Pedagogia e Psicologia pela Universidade Federal do Rio de Janeiro. Coordenadora de Educação a Distância, Coordenadora de Pesquisa e Pós-Graduação e Professora Assistente na Faculdade de Medicina de Petrópolis / Faculdade Arthur Sá Earp Neto. Avaliadora ad hoc de cursos de graduação de Pedagogia e Psicologia pelo MEC/INEP.

\section{ANTONIA SANDRA VERAS LÉLIS}

Discente do curso de Pedagogia da Universidade Federal ao Piauí.

\section{ANTÔNIA SHIRLEY FERREIRA DOS SANTOS BRITO}

Discente do curso de Pedagogia da Universidade Federal ao Piauí.

\section{ANTÔNIO VICO MAÑAS}

Pós-Doutor em Administração - FEAUSP (2004), Doutor em Ciências Sociais - PUCSP (1999), Mestre em Administração - PUCSP (1991), Graduação em Administração de Empresas (1973). Professor da PUC-SP. Pesquisador Consultor e Palestrante. Vice-Reitor da PUC-SP até 2012. Laureado com título de Outstanding Administrator pelo Conselho Regional de Administração de São Paulo e com o Arco da Paz como professor pela Cidade de São Paulo. Membro do Conselho do FORGES, coordenador do GEGIES - CRASP e diretor da Assoc. Comercial de São Paulo.

\section{ATTILIO VALENTINI}

Mestre em Medicina, com área de Concentração em Dermatologia, pela Universidade Federal Fluminense (UFF), graduado em Medicina na UFF, com Residência em Clínica Médica no Hospital do IASERJ e em Dermatologia, no Hospital Universitário Antônio Pedro, da UFF e especialização em Educação Médica pela Faculdade de Medicina de Petrópolis (FMP)/UNIFESP. Especialista em Dermatologia pela Associação Médica Brasileira / Sociedade Brasileira de Dermatologia. Professor Assistente responsável pela disciplina de Dermatologia da FMP. Membro efetivo da Sociedade Brasileira de Dermatologia. Médico Dermatologista na Secretaria Municipal de Saúde de Petrópolis. Coordenador do Comitê de Ética em Pesquisa da FMP / FASE / Hospital de Ensino Alcides Carneiro.

\section{BIANCA PEREIRA MOREIRA OZORIO}

Graduada em Engenharia Civil pela Universidade Federal do Rio Grande - FURG (2002), mestre em Engenharia Civil pela Universidade Federal de Santa Maria - UFSM (2004) e doutora em Engenharia de Estruturas pela Escola de Engenharia de São Carlos da Universidade de São Paulo - EESC/USP (2016). Docente do curso de Engenharia Civil (2008-2018) da Universidade Federal do Rio Grande, e atualmente atua como coordenadora do curso de Engenharia de Produção.

\section{BRUNA GONCCALVES DE SOUZA}

Possui doutorado pela Universidade Federal de São Carlos - UFSCar - na área de Engenharia Química, com ênfase em Reatores Químicos Heterogêneos e Catálise, com participação no projeto internacional "Excellence Center for Development Cooperation - Sustainable Water Manegement" (financiado pela DAAD e coordenado pela Universidade Técnica de Braunschweig/Alemanha). Possui mestrado em Engenharia Química pela mesma universidade e graduação em Engenharia Química pela Universidade Estadual de Maringá - UEM. 


\section{BRUNO MIRANDA DOS SANTOS}

Doutorando em Engenharia de Produção pela Universidade Federal do Rio Grande do Sul (UFRGS). Mestre em Engenharia de Produção pela Universidade Federal de Santa Maria (UFSM). Graduado em Engenharia de Produção pela UFSM.

\section{CHARLENE BARBOSA DE PAULA}

Graduanda no Curso de Licenciatura em Química na Universidade Federal de Pelotas - UFPel, com previsão para conclusão em 2019 e técnica em Química pelo Instituto Federal e Educação, Ciência e Tecnologia Sul-Rio-Grandense - IFSUL.

\section{CYNTHIA HELENA SOARES BOUÇAS TEIXEIRA}

Graduação em Engenharia Química pela Universidade Federal de Minas Gerais (1998), mestrado em Engenharia Metalúrgica e de Minas pela Universidade Federal de Minas Gerais (2001), doutorado em Engenharia Metalúrgica e de Minas pela Universidade Federal de Minas Gerais (2005) e certificação em Engenharia da Qualidade pela ASQ (2015). Possui experiência profissional nas áreas de Pesquisa \& Desenvolvimento, Gestão do Conhecimento, Transferência de Tecnologia e Propriedade Intelectual em empresa do ramo siderúrgico. Em especialização pela Faculdade de Ciências Econômicas da Universidade Federal de Minas Gerais. Atua nas áreas de Ensino em Engenharia, de Metodologias e Ferramentas Estatísticas para Processos Industriais e de Administração de Empresas.

\section{DANIELE DA ROCHA CARVALHO}

Graduação em Ciências Contábeis pela Universidade Federal do Rio Grande do Norte (2002) e mestrado em Ciências Contábeis pela Universidade de Brasília (2010). Atualmente é professor de ensino superior da Universidade Federal do Rio Grande do Norte. Tem experiência na área de Administração, com ênfase em Ciências Contábeis, atuando principalmente nos seguintes temas: Custos, Contabilidade Pública, Contabilidade Financeira e Atuária. Possui publicações em eventos na área de Custos (nacionais e internacionais) e na área de Educação (ENFORSUP, ENDIPE e ENAPPE). Co-autora de um dos capítulo do livro "Docência Universitária: Saberes e Práticas em Construção", publicado em 2011. Co-autora de um dos capítulos do livro "Contabilidade Comportamental: Conceitos e Aplicações", publicado em 2017. Ministrou cursos na área de Formação de Professores para a EJA. Doutoranda em Educação (PPGED/UFRN).

\section{DANIELLY NORBERTO ARAÚJO}

Graduada (2017) em Engenharia Elétrica pela Universidade Federal de Campina Grande (UFCG). Mestre (2020) em Engenharia elétrica pela Universidade Federal do Ceará (UFC). Foi pesquisadora no Laboratório de Energias Alternativas da UFC (2018-2020), atualmente é pesquisadora no Instituto de Tecnologia Edson Mororó Moura. Seus interesses são: geração distribuída, energia solar e sistemas de armazenamento de energia.

\section{DAVI TEIXEIRA PINHEIRO}

Professor do Departamento de Construção Civil (DCC) do Instituto Federal de Educação, Ciência e Tecnologia do Ceará (IFCE), campus Fortaleza. Graduado em Engenharia Civil (2006) e Engenharia de Produção Mecânica (2013) pela Universidade Federal do Ceará (UFC), especialista em Gerenciamento de Projetos (2012) pela Fundação Getúlio Vargas (FGV), mestre em Administração e Controladoria (2018) pela Universidade Federal do Ceará (UFC) e aluno do Programa Doutoral em Engenharia Civil (PRODEC) da Faculdade de Engenharia da Universidade do Porto (FEUP). Atuou como Coordenador de Obras Públicas da Construtora Castelo Branco (CCB), Coordenador de Infraestrutura da Secretaria Regional II da Prefeitura Municipal de Fortaleza e Coordenador da Assessoria dos Projetos Especiais da Secretaria da Casa Civil do Governo do Estado do Ceará e, também, como professor do Instituto de Educação Continuada (INBEC) nos cursos de extensão e especialização na área da engenharia civil. 


\section{DIONIS DE CASTRO DUTRA MACHADO}

Fisioterapeuta, mestre e doutora em Saúde Mental pela Universidade Federal do Rio de Janeiro, professora adjunto III da Universidade Federal do Piauí / centro de Ciências da Saúde / Departamento de Educação Física.

\section{DIRCE CHARARA MONTEIRO}

Mestra em Letras pela Universidade de São Paulo -USP e Doutora em Letras pela Universidade Estadual Paulista - UNESP FACLAr. Professora aposentada da Faculdade de Ciências e Letras da UNESP - Campus de Araraquara/SP. Coordenadora., docente e pesquisadora do PPG em Processos de Ensino, Gestão e Inovação Mestrado Profissional na Área de Educação - UNIARA. Docente do Curso de Pedagogia da UNIARA.

\section{DMONTIER PINHEIRO ARAGÃO JÚNIOR}

Graduado em Ciências da Computação pela UFC (2004), mestre em Engenharia de Transportes também pela UFC (2009) onde desenvolveu metodologia de monitoramento de arranjos produtivos e com doutorado em Engenha de Produção na UFSC (2014), quando estudou a colaboração em sistemas multiagentes na roteirização dinâmica de veículos. Já tendo feito parte de projetos nacionais e internacionais na área de transporte, logística, arranjos produtivos, sistemas de informações e software livre. Atualmente é professor na Universidade Federal do Ceará no campus Russas onde pesquisa principalmente Roteirização Dinâmica de Veículos, Sistemas Especialistas e Metodologias de Benchmarking.

\section{DOUGLAS SOARES AGOSTINHO}

Mestre em Engenharia de Produção pela Universidade Federal do Paraná - UFPR, pós graduado em ADMINISTRAÇÃO DA PRODUÇÃO pela ESAN, pós-graduado em FORMAÇÃO DE DOCENTES E DE ORIENTADORES ACADÊMICOS EM EAD pelo CENTRO UNIVERSITÁRIO UNINTER e graduado em ENGENHARIA OPERACIONAL MECÂNICA pela Universidade Braz Cubas, graduado também em ENGENHARIA INDUSTRIAL MECÂNICA pela Universidade Braz Cubas. Trabalha como Coordenador dos cursos de Graduação em Engenharia de Produção nas modalidades Presencial, Semi presencial e a Distância, do CENTRO UNIVERSITÁRIO UNINTER. Atua, também, como professor de Matemática Aplicada, Estudo de Tempos e Métodos, Métodos Quantitativos, Gestão Estratégica de qualidade, Desenho Técnico, entre outros. Vivência profissional, atuou por 30 anos em empresas de manufatura, nas áreas de Produção, Qualidade, Manutenção, Logística, Engenharia de Processos e Engenharia Industrial.

\section{EDENIA NASCIMENTO BARROS}

Graduação em Construção Civil pela Universidade Regional do Cariri (2003), graduação em Engenharia Civil pela Universidade Federal do Cariri (2013) e Especialização em Gerenciam ento da Construção Civil pela Universidade Regional do Cariri (2017). Atualmente é técnico de laboratório/área da Universidade Federal do Cariri. Tem experiência na área de Construção Civil, atuando principalmente nos seguintes temas: argamassa, concreto e resíduos da construção civil.

\section{EDUARDO COSTA ESTAMBASSE}

Doutorando em Engenharia Mecânica do programa de Pós-Graduação da UNESP, Mestre em Engenharia Mecânica pela UNESP - Bauru-SP (2015). Pós-graduado em Gestão Industrial com Enfase em Sistemas de Produção, Pós-graduado em Engenharia de Manutenção ambas pela Faculdade de Tecnologia SENAI Florianópolis. Graduado em Tecnologia em Mecânica pela Universidade Tecnológica Federal do Paraná (2009). Técnico Mecânico Centro Paula Souza - Ourinhos SP - 2003. Atuo na área Metal Mecânica há 20 anos nas seguintes áreas: Engenharia de Manutenção Industrial e Produção, abrangendo os Processos de Fabricação, Usinagem, Estamparia, Soldagem, Metrologia e Gestão da Manutenção. 


\section{ELIEDSON RAFAEL DE CARVALHO}

Mestrando em Engenharia Civil. Especialista em Docência do Ensino Superior. Engenheiro Civil com Graduação Parcial nos EUA.

\section{ELTON IVAN SCHNEIDER}

Diretor da Escola de Gestão e Negócios do Centro Universitário Internacional Uninter. Avaliador MEC/INEP para cursos de graduação e instituições de ensino desde 2010. Possui graduação em ADMINISTRAÇÃO pela Universidade Federal de Santa Maria (1992) e Pós-graduação em Qualidade na Administração (UFSM,2000), Pós-graduado em Tutoria em EAD, Mestrado em Engenharia e Gestão do Conhecimento (EGC - UFSC-2012), Doutorado em Administração pela Universidade Positivo em Curitiba - PR, na linha de pesquisa de Estratégia, Inovação e Sustentabilidade.

\section{ENGELS ZALMOM DE CARVALHO LACERDA}

Graduando em Engenharia Civil pela Universidade Federal do Cariri - UFCA; Membro do Escritório Habitar, projeto de extensão da Universidade Federal do Cariri - UFCA; Autor de artigos científicos em congressos nacionais.

\section{ERCILIA DE STEFANO}

Professora Adjunta da Universidade Federal Fluminense. Leciona as disciplinas de Gestão de Projetos, Gestão de Projetos de Sistemas de Produção, Gestão da Inovação Tecnológica, Empreendedorismo I e II. Realiza pesquisas nas áreas de Inteligência Artificial, Machine Learning, Deep Learning, dentre outras. Pós-doutora em Engenharia Civil pela UFRJ - COPPE. Pós-doutora em Sistemas de Gestão Sustentáveis pela UFF. Doutora em Engenharia de Transportes pela UFRJ COPPE. Mestre em Engenharia de Sistemas pela UFRJ - COPPE. MBA em Gestão Estratégica em Comércio Exterior. Especialista em Gestão Estratégica Pública. Especialista em Gerência e Desenvolvimento de Sistemas Orientado a Objetos. Graduada em Matemática. Advogada.

\section{ERWIN ULISES LOPEZ PALECHOR}

Graduado em Engenharia Civil pela Universidade del Cauca/UNICAUCA -Colômbia (2010), Mestre em Estruturas e Construção Civil pela Universidade de Brasília/UNB (2013) e Doutor em Estruturas e Construção Civil pela Universidade de Brasilia/UNB (2018). Atualmente, é Professor Adjunto e Coordenador do Laboratório de Estruturas no Curso de Engenharia Civil da Universidade Federal do Cariri (UFCA). Tem experiência na área de Engenharia Civil com ênfase em Pontes, Estruturas de Concreto e Estruturas Metálicas. Autor de artigos científicos em congressos nacionais e internacionais.

\section{FATIMA MARIA ALVES MINUZZO}

Mestre em Dermatologia pela Universidade Federal Fluminense (UFF). Especialista em Educação Médica pela EPM. Graduada em Medicina na UFF com Residência em Clínica Médica, com concentração em Dermatologia pela UFF. Professora de Dermatologia na Faculdade de Medicina de Petrópolis. Professora adjunta da disciplina de Dermatologia na UFF até 1986.

\section{FILIPI MOLINAR MACHADO}

Professor no Departamento de Engenharias e Ciências da Computação (DECC) na Universidade Regional Integrada do Alto Uruguai e das Missões (URI), campus Santo Ângelo, atuando como docente, pesquisador e orientador. Doutor em Engenharia Agrícola pela UFSM (2018), mestre em Engenharia de Produção pela UFSM (2014) e graduado em Engenharia Mecânica pela URI (2007). 


\section{FRANCISCA AMANDA DA SILVA MARTINS}

Graduanda em Ciências Biológicas (Licenciatura), na Universidade Estadual do Ceará (UECE). Atualmente, bolsista CAPES do Programa Institucional de Bolsas de Iniciação à Docência (PIBID), realizando atividades no Campus de Fortaleza do Instituto Federal de Educação, Ciência e Tecnologia do Ceará (IFCE). Tem experiência na área de Aquicultura, com ênfase em Carcinicultura. Atua na área de Educação.

\section{FRANCO DA SILVEIRA}

Doutorando em Engenharia de Produção na UFRGS (2018), mestre em Engenharia de Produção pela UFSM (2018) e Engenheiro Mecânico pela Universidade Regional Integrada do Alto Uruguai e das Missões (URI, 2015). Membro do Núcleo de Capacitação em Ergonomia, Saúde e Segurança Ocupacional (NECSSO) do Laboratório de Otimização de Produtos e Processos (LOPP).

\section{FRANKLYN KENNEDY DA SILVA}

Graduado pelo Curso de Ciências Contábeis da Universidade Federal do Rio Grande do Norte - UFRN.

\section{GABRIELE AZAMBUJA COELHO RODRIGUES}

Graduanda do curso de Engenharia Civil da Universidade Federal do Rio Grande - FURG. Participou como voluntária no Laboratório de Geotecnia e Concreto na FURG, realizando ensaios geotécnicos de materiais de construção civil e solos. Realizou projetos de ensino e pesquisa na área estrutural, sendo o primeiro "FTOOL: Roteiro para utilização do software em treliças planas, vigas e pórticos planos" e o segundo sobre "Análise de Confiabilidade de Vigas Protendidas Pós-tracionadas". Fez parte do grupo PET-Engenharia Civil por quatro anos, trabalhando com atividades de ensino, pesquisa e extensão e desenvolvendo trabalhos em grupo.

\section{GABRIELLE DOS SANTOS MARQUES}

Aluna do Curso de Engenharia de Produção Mecânica desde 2017.1 na Universidade Federal do Ceará - UFC.

\section{GEAN APARECIDO ZAPATEIRO}

Licenciado em Química e Mestre em Ensino de Ciências Humanas, Sociais e da Natureza pela Universidade Tecnológica Federal do Paraná. Licenciado em Pedagogia pela Universidade Cruzeiro do Sul. Especialização em Ensino Lúdico pela Faculdade de Educação São Luís. Tem experiência nas áreas de ensino de química, formação de professores, jogos e recursos didáticos.

\section{JEANNE BARROS LEAL DE PONTES MEDEIROS}

Doutorado em Educação (2017) pela Universidade Estadual do Ceará, Mestrado em Desenvolvimento e Meio Ambiente (2004) pela Universidade Federal do Ceará, Especialização em Botânica (1995) e Graduação em Ciências Biológicas pela Universidade Federal do Ceará nas modalidades Licenciatura (1994) e Bacharelado (1995). É professora adjunta e atualmente coordena o Curso de Ciências Biológicas/ CCS da Universidade Estadual do Ceará, onde preside o Núcleo Docente Estruturante. Coordena os estágios do Curso de Licenciatura em Ciências Biológicas UAB/UECE e o Laboratório de Formação de Professores - LAFORP. Tem experiência na área de Botânica, com ênfase em Taxonomia de Criptógamas . Atua nas áreas de Formação de Professores e Currículo. 


\section{JESIMIEL PINHEIRO CAVALCANTE}

Mestre em Engenharia Industrial, Engenheiro Civil e Segurança do Trabalho, Especialista em Gerenciamento da Construção Civil.

\section{JOÃO ÁLCIMO VIANA LIMA}

Professor de História da Educação da Universidade Estadual do Ceará (UECE). Graduação em História e mestrado em Gestão Educacional. Foi o diretor fundador do Centro de Educação, Ciências e Tecnologia da Região dos Inhamuns (CECITEC), campus da UECE sediado em Tauá/CE. Foi Secretário de Ciência, Tecnologia e Empreendedorismo de Tauá/CE (2005/2008) e Secretário da Educação de Tauá/Ceará (2009/2013 e 2014/2016). Realizou consultoria junto à SASE/MEC, na condição de Avaliador Educacional (2013/2015 e 2017/2018). Coordena o curso de Pedagogia vinculado à UECE/CECITEC, no âmbito do Parfor e compõe o Banco de Avaliadores do Sistema Nacional de Avaliação da Educação Superior (BASis), do INEP. É autor, dentre outras publicações, do livro "Gestão e autonomia universitária: a experiência da UECE".

\section{JOSÉ DUTRA DE OLIVEIRA NETO}

Técnico em Contabilidade na modalidade EaD.Possui graduação em Engenharia Elétrica pela Fundação Armando Álvares Penteado (1984), mestrado em Engenharia Elétrica pela Universidade Estadual de Campinas (1987) e doutorado em Controladoria e Contabilidade pela Universidade de São Paulo (1999). Fez Pós-Doutorado na University of Illinois at Urbana-Champaign na faculdade de Educação sobre Qualidade em EaD (2008-2009). É professor Livre-docente pela Universidade de São Paulo. Tem atuando principalmente nos seguintes temas: EaD, Tecnologias de Aprendizagem, Design Instrucional, Sistemas de Informação. Possui experiência, desde 1999, em diversos LMS como Webct, Teleduc e principalmente Moodle. Foi Coordenador de Design Instrucional do projeto USP/UNIVESP de 2010 a 2011. Foi responsável pela capacitação dos tutores no projeto REDEFOR entre 2011-2012. Coordenador do Núcleo de pesquisa NPT junto a pró-reitoria de cultura e extensão. Organizador do workshop NPT sobre EaD que está em sua décima segunda edição. Membro do comitê científico da ABED a partir de 2011. Orientador de IC na FEA-RP/USP e Mestrado e Doutorado em EaD na FEA-RP . Responsável pelo convênio Internacional entre a UNM- EUA e a FEA-RP/USP para intercâmbio de professores e alunos e desenvolvimento de um projeto de jogos de empresas em um ambiente multicultural. Coordenador da pesquisa internacional sobre recursos educacionais abertos em parceria com UCT (South Africa) e IDRC do Canada sobre REA em diversos países de 3 continentes (AL, Ásia e África). Projeto CNPq Modelo Vivencial de aprendizagem intercultural em simuladores de empresas (2014-2017). 459498/2012-2. Responsável pelo Projeto de cooperação internacional entre TNTECH e FEARP. doc 36869. 1. Intercâmbio de estudantes para aproveitamento de crédito 2 Intercâmbio de docentes 3. Programas acadêmicos especiais de curta duração. Pós-doutorado na UNM-USA para desenvolvimento de pesquisa acerca dos MOOC em 2016. Ganhador do prêmio-bolsa CANVAS em 2016 sobre OER.

\section{JOSÉ RICARDO COSTA BASILIO}

Mestre em Educação em Ciências e Saúde pela Universidade Federal do Rio de Janeiro e graduado em Administração de Empresas pela Universidade Cândido Mendes. Professor assistente da Faculdade de Medicina de Petrópolis/Faculdade Arthur Sá Earp Neto atuando na Coordenação de Educação a Distância. Tem experiência na área de Ciência da Computação, com ênfase em desenvolvimentos de Sistemas de Computação, concepção e desenvolvimento de mídias educacional, atuando principalmente nos seguintes temas: aprendizagem, ensino a distância, tecnologia da informação, recursos humanos, trânsito, educação e capacitação. 


\section{JUAN CARLOS GEREZ}

Formado em Engenharia Civil pela Universidade Federal do Rio Grande - FURG, participou como voluntário do Serviço de Assistência à Construção Civil (SAsCC) Profa Dacila Vitola. Atuou no Grupo Programa de Educação Tutorial (PET) - Engenharia Civil da FURG durante os anos de 2015 a 2018 desenvolvendo atividades de ensino, pesquisa e extensão com projeto de ensino premiado durante o Encontro Nacional dos Estudantes de Engenharia Civil (ENEC) de 2018.

\section{JULIANA LIRA BRITO DE CARVALHO}

Engenheira Civil e Técnica em Edificações.

\section{KAROLINE PEREIRA FAGUNDES}

Técnica em eletrotécnica pelo Instituto Federal Sul Rio Grandense - Campus Pelotas, graduanda do curso de Engenharia Civil na Universidade Federal do Rio Grande - FURG e membro do grupo PET Engenharia Civil durante os anos de 2017 a 2019.

\section{LEONARDO MELO BEZERRA}

Graduação em Engenharia Civil pela Universidade Federal do Ceará (1996), mestrado em Estruturas e Construção Civil pela Universidade de Brasília (2001) e Doutorado pela Universidade de São Paulo - Escola de Engenharia de São Carlos EESC/USP (2011). Atualmente é Professor Adjunto na Universidade Federal do Ceará (UFC). Tem experiência na área de Engenharia Civil, com ênfase em Estruturas mistas, atuando principalmente nos seguintes temas: estruturas mistas, concreto armado, dimensionamento, análise estrutural.

\section{LUCAS GONÇALVES DE FREITAS}

Graduando em Engenharia Civil pela Universidade Federal de Pelotas, técnico em eletrotécnica, trabalhou como Assessor de Projetos e Diretor de Recursos Humanos na Atena Consultoria Jr., Empresa Júnior de Engenharia Civil da Universidade Federal do Rio Grande - FURG, onde também foi bolsista do Programa Educação Tutorial (PET) Engenharia Civil, com pesquisa premiada na Área de Sustentabilidade. Atualmente é estagiário de planejamento de obras na Construtora Zabaleta, e trabalha com pesquisas voltadas à gestão de obras.

\section{LUCAS VINICIOS OLIVEIRA FILGUEIRAS}

Graduação em Engenharia Elétrica, com aprofundamento de estudos em eletrotécnica, pela Universidade Federal de Campina Grande (2018). Concluiu projeto de Iniciação Científica no Laboratório de Eletrônica Industrial e Acionamento de Máquinas (LEIAM) com enfoque em Energia Solar Fotovoltaica. Concluiu também projeto de Iniciação Tecnológica e Industrial envolvendo Redes Elétricas Inteligentes. Participou do programa de intercâmbio BRAFITEC - Capes em Grenoble, França, onde estudou na École Nationale Supérieure de Physique, Électronique et Matériaux PHELMA. Além disso, foi estagiário no departamento de operação da empresa Energisa Paraíba. Atualmente, é mestrando no Programa de Pós Graduação em Engenharia Elétrica da Universidade Federal do Ceará (UFC), na área de Inteligência Computacional Aplicada. Sua área de interesse envolve estudos nas áreas de Ciência de Dados, Inteligência Computacional, Fontes Renováveis de Energia Elétrica e Redes Elétricas Inteligentes.

\section{LUCIANA TEIXEIRA VELLOSO}

Pós-graduada em Dermatologia, na Universidade do Estado do Rio de Janeiro com título de especialista pela Sociedade Brasileira de Dermatologia. Graduada em Medicina na UERJ. Professora da disciplina de Dermatologia da Faculdade de Medicina de Petrópolis. 


\section{LUCIANO BASTOS DE CARVALHO}

Doutorando em Controladoria e Contabilidade pela Universidade de São Paulo (USP) campus Ribeirão Preto. Mestre em Controladoria e Contabilidade pela Universidade de São Paulo (USP) campus Ribeirão Preto. MBA em Contabilidade e Governança pela FUNDACE/USP. Especialista em Contabilidade, Auditoria e Perícia. Graduado em Ciências Contábeis e em Administração pela Pontifícia Universidade Católica de Minas Gerais (PUC MINAS) campus Poços de Caldas. Docente nos cursos de Graduação em Administração e Técnico em Administração do Instituto Federal do Espírito Santo - campus Barra de São Francisco. Membro ativo do grupo de pesquisa NPT - Núcleo para o Desenvolvimento de Tecnologia e Ambientes Educacionais/ FEARP/USP. Possui experiência nas áreas de Administração, Auditoria, Contabilidade Gerencial, Contabilidade Societária, Contabilidade Pública e Educação em Contabilidade.

\section{LUCIANO FURTADO CORREA FRANCISCO}

Profissional atuante desde 1988 na área de informática, administração e docência, com amplo conhecimento no desenvolvimento de sistemas e negócios em Tecnologia da Informação. Experiência em análise de sistemas, análise de negócios, modelagem de dados e processos e plataformas de E-commerce. Pós-graduado em Redes e Sistemas Distribuídos (PUC/PR, 1995). Bacharel em Processamento de Dados (UEPG, 1991). Bacharel em Administração (UNIFAE, 2000). Atuação como docente desde 2005 em nível médio, técnico, cursos preparatórios e nível superior. Atualmente professor-tutor dos cursos superiores de Tecnologia em Logística e do curso de Tecnologia em Gestão do E-commerce e Sistemas Logísticos, do Centro Universitário Internacional - UNINTER.

\section{LUIS CLÁUDIO VILLANI ORTIZ}

Professor de Economia do Instituto Federal Goiano. Graduação em Ciências Econômicas pela Universidade Regional do Noroeste do Estado do RS (UNIJUI, 1996), Pós Graduado em Economia Monetária, Mestre em Economia pela UFRGS e Doutor pelo Programa de Pós-Graduação em Desenvolvimento Regional pela UNISC/RS.

\section{LUIZ FERNANDO GOMES PINTO}

Graduado em Administração de Empresas pela Fundação Getulio Vargas (1990), com especialização em Administração de Empresas pelo Insper (2003) e mestrado em Administração de Empresas pela Universidade Presbiteriana Mackenzie (2007). Coordenador e professor do curso na modalidade EaD de Tecnologia em Marketing e de Tecnologia em Gestão Comercial do Centro Universitário Senac. Profissionalmente, possui experiência em marketing como gerente de produto e gerente de marketing em empresas nacionais e multinacionais de produtos de consumo.

\section{MALLENA SOARES DA SILVA}

Engenheira Civil Técnica em Edificações. Técnica em Edificações da Saúde Indígena.

\section{MARCELO DE SOUSA ALVES}

Graduando em Engenharia Civil pela Universidade Federal do Cariri - UFCA; Membro do Escritório Habitar, projeto de extensão da Universidade Federal do Cariri - UFCA; Autor de artigos científicos em congressos nacionais. 


\section{MÁRCIA CAMILO FIGUEIREDO}

Licenciada em Química, Universidade Estadual de Maringá. Mestre em Educação para a Ciência e a Matemática, Universidade Estadual de Maringá, UEM. Doutora em Educação para a Ciência, Universidade Estadual Paulista Júlio de Mesquita filho (UNESP), Câmpus Bauru. Professora do Magistério Superior na Universidade Tecnológica Federal do Paraná, UTFPR, Câmpus Londrina, Departamento Acadêmico de Química. Tem experiência nas áreas de Metodologias e Práticas para o Ensino de Ciências/Química, Estágio Supervisionado, formação inicial e continuada de professores, Ciência-Tecnologia-Sociedade-Ambiente - CTSA, Tecnologias de Informação e Comunicação (TIC) aplicadas ao ensino.

\section{MARCOS RONALDO ALBERTIN}

Graduação em Engenharia Mecânica pela Pontifícia Universidade Católica do Rio Grande do Sul (1983), mestrado em Engenharia Industrial - FH-Bochum Universität (1993) e doutorado em Engenharia de Produção pela URGS (2003). Atualmente é Prof. Associado e Chefe do Departamento de Engenharia de Produção do Centro de Tecnologia da Universidade Federal do Ceará. Pósdoutorado no Bremer Institut für Produktion und Logistik (2009) em Monitoramento de Sistemas Produtivos. Pós-doutorado no IPK - Fraunhofer no tema Benchmarking (2013). Extensão universitária em garantia da qualidade para o ensino superior Vienna University of Technology, 2016). Capacitação em Berlim (2018).

\section{MARCOS WURZER}

Graduação em Engenharia Mecânica pela Universidade Federal do Paraná (1990) e mestrado em Engenharia Elétrica e Informática Industrial pela Universidade Tecnológica Federal do Paraná (2006). Atuou como Supervisor Geral da Engenharia Industrial na unidade da Volkswagem-Audi em Curitiba e como professor adjunto da Universidade Tuiuti do Paraná. Tem experiência na área de Engenharia Mecânica, com ênfase em Gestão de Projetos, Eng. desenvolvimento de produto, Eng. Produção, Balanceamento de Linha de Produção, Processos de fabricação, Produtividade, Qualidade e Performance Industrial. Atuou como Gerente de Projetos e Engenheiro de Desenvolvimento de Produtos - Brose do Brasil Ltda. Atualmente é professor do Centro Universitário UNINTER.

\section{MARIA BETANEA PLATZER}

Pedagoga e Mestra em Educação Escolar pela Universidade Estadual Paulista (UNESP). Doutora em Educação pela Universidade Estadual de Campinas (UNICAMP). Docente e pesquisadora do Programa de Pós Graduação em Processos de Ensino, Gestão e Inovação , Mestrado Profissional da Área de Educação - Universidade de Araraquara (UNIARA). Docente dos Cursos de Pedagogia e Biologia da Universidade de Araraquara (UNIARA).

\section{MARIA ELVIRA SILVA DE SOUSA}

Graduanda em Ciências Biológicas (Licenciatura Plena), na Universidade Estadual do Ceará (UECE). Atualmente, é bolsista do programa PROMAC como monitora da disciplina de Biologia Celular. Tem experiência na área de Conservação de Quelônios Marinhos e Biologia de Campo, com foco em regiões litorâneas. Atua nas áreas de Educação Ambiental e Educação Básica (Ensino Fundamental 2 e Ensino Médio).

\section{MARIA LUCIA OLIVEIRA SUZIGAN DRAGONE}

Doutora e Mestra em Educação Escolar pela Universidade Estadual Paulista (UNESP FCLAr;) Fonoaudióloga pela Pontifícia Universidade Católica de Campinas (PUCCamp). Docente e pesquisadora do PPG Processos de Ensino Gestão e Inovação Mestrado Profissional na área da Educação - Universidade de Araraquara-UNIARA. Docente do Curso de Pedagogia - Universidade de Araraquara UNIARA. 


\section{MARIA REGINA GUARNIERI}

Pedagoga pela Universidade Estadual Paulista Júlio de Mesquita Filho (UNESP), Mestra e Doutora em Educação na área de Metodologia de Ensino pela Universidade Federal de São Carlos/SP (UFSCAR). Professora aposentada da Faculdade de Ciências e Letras da UNESP - Campus de Araraquara/SP. Docente e pesquisadora do PPG em Processos de Ensino, Gestão e Inovação Mestrado profissional da Área de Educação - UNIARA.

\section{NELSON FRANCISCO FAVILLA EBECKEN}

Doutorado em Engenharia Civil pela Universidade Federal do Rio de Janeiro em 1977. Desde 1990 é PROFESSOR TITULAR da Universidade Federal do Rio de Janeiro. Publicou 135 artigos em periódicos especializados e 361 trabalhos em anais de eventos. Possui 19 livros publicados. Orientou 135 dissertações de mestrado e 138 teses de doutorado nas áreas de Engenharia Civil/Sistemas Computacionais. Recebeu 8 prêmios e/ou homenagens. Atua em áreas interdisciplinares da Engenharia e Engenharia de Petróleo, com ênfase em Sistemas Computacionais. Em suas atividades profissionais interagiu com 161 colaboradores em co-autorias de trabalhos científicos.

\section{PAULO CESAR CHAGAS RODRIGUES}

Graduação em Administração Com Gestão Em Informática pela Faculdade Gennari Peartree em 2005, cursou Pós-graduação latu-sensu a nível de Especialização em Gestão Empresarial na Faculdade Fenix de Bauru e em Gestão Pública na Universidade Dom Bosco e Pós-Graduação Strictusensu a nível de Mestrado em Engenharia de Produção na Faculdade de Engenharia de Bauru UNESP e Pós-Graduação Strictu-sensu a nível de doutorado em Engenharia Mecânica na Faculdade de Engenharia de Guaratinguetá - UNESP.

\section{PRISCILLA CHANTAL DUARTE SILVA}

Professora Adjunto IV da Universidade Federal de Itajubá, na área de Comunicação e Expressão e Metodologia de Pesquisa, nas Engenharias. Graduou-se em Letras com Habilitação em Português / Inglês, pela Pontifícia Universidade Católica de Minas Gerais, em 2005 e obteve o título de Mestre em Linguística e Língua Portuguesa pela mesma instituição, em 2008 (bolsista CAPES). Em seu mestrado, estudou, na Análise do discurso e na Filosofia da Linguagem, a intencionalidade da mente, com um enfoque na intencionalidade discursiva em charges políticas, visando identificar a direcionalidade semântica nesse gênero textual.

\section{RAYLANE VIRGINIA VENANCIO FERREIRA LIMA}

Discente do curso de Pedagogia da Universidade Federal ao Piauí.

\section{RENNAN OTAVIO KANASHIRO}

Professor na Universidade Norte do Paraná (Unopar). Graduação e Mestrado em Engenharia Mecânica pela Universidade Tecnológica Federal do Paraná - UTFPR. Trabalha com temas: Identificação de Sistemas, Problema Inverso e Otimização.

\section{RICARDO LUIZ PEREZ TEIXEIRA}

Professor adjunto na Universidade Federal de Itajubá Campus de Itabira, Curso de Engenharia dos Materiais. Doutor em Ciências, Engenharia Metalúrgica e de Materiais pela Universidade Federal do Rio de Janeiro (2011) com doutorado em cotutela em Engenharia Mecânica pela Faculdade de Engenharia da Universidade do Porto (2011), Mestre em Engenharia Metalúrgica e de Minas pela Universidade Federal de Minas Gerais (2004), Graduado em Engenharia Química pela Universidade Federal de Minas Gerais (1996) e especialista em Engenharia de Segurança do Trabalho pela Universidade Federal de Minas Gerais (1998). Professor de magistério superior pela Universidade Federal de Itajubá campus avançado de Itabira para cursos envolvendo materiais metálicos e compósitos (2013). 


\section{RIDALVO MEDEIROS ALVES DE OLIVEIRA}

Doutor em Educação pela Universidade Federal do Rio Grande do Norte (2011). Mestre em Ciências Contábeis pela Universidade de Brasília (2003). Especialista em Contabilidade Gerencial pela UFRN (1999). Graduado em Ciências Contábeis pela Universidade Federal do Rio Grande do Norte (1995). Professor do Departamento de Ciências Contábeis da UFRN. Diretor-Geral do Núcleo Permanente de Concursos (COMPERVE) da UFRN. Experiência na área de logística de concursos, de vestibulares e de processos seletivos, e também na área de Contabilidade, com ênfase em Custos, Controladoria e Contabilidade Gerencial.

\section{ROBERTO CANDIDO PANSONATO}

Pós-graduado MBA Executivo em Liderança e Desenvolvimento Gerencial pela Estação Business School (Curitiba / PR, 2011), especialista em Formação Docente para EAD - UNINTER (Curitiba / PR, 2019), graduado em Desenho Industrial pela Faculdade de Desenho Industrial de Mauá (Mauá / SP, 1988). Green Belt Six Sigma pela Unicamp (2003). Larga experiência nas áreas de Engenharia de Produção e Lean Manufacturing. Professor do Centro Universitário Uninter, nos cursos de Bacharel em Administração, Bacharel em Engenharia da Produção e Tecnologia em Logística. Atua como Tutor EaD no Centro Universitário Uninter.

\section{ROBSON SELEME}

Doutor em Engenharia de Produção (UFSC), Mestre em Engenharia de Produção (UFSC), Especialização em Formação de Docentes e Orientadores Acadêmicos, Especialização em MBA Finanças Internacionais, Graduado em Engenharia Civil pela (UMC), Engenheiro de Segurança do Trabalho pela PUC / Paraná. Coordenador do Programa de Mestrado em Engenharia de Produção da UFPR, Coordenador do curso de especialização em Engenharia de Produção da UFPR. Professor adjunto de nível superior da Universidade Federal do Paraná. Tem experiência na área de Engenharia de Produção e Civil, atuando nos seguintes temas: qualidade de bens e serviços, logística, gestão da produção, sistemas de planejamento e produção e educação a distância.

\section{ROGÉRIO SEVERIANO DUTRA}

Pós-graduado em Administração e Controladoria em nível STRICTO SENSU pela Universidade Federal do Ceará. Pós-graduado em Gestão Pública e Contabilidade Pública e Lei de Responsabilidade Fiscal em nível LATO SENSU pela Universidade Cândido Mendes. Graduado em Ciências Contábeis pela Faculdade de Economia, Administração, Atuaria, Contabilidade e Secretariado Executivo na Universidade Federal do Ceará e graduado no curso de Licenciatura Plena em Matemática pela Universidade Estadual do Ceará. Graduando em Administração Pública pela Universidade Estadual do Ceará. Atualmente tenho interesse em pesquisas relacionadas Avaliação de Politicas Públicas Educacionais. Ocupo o cargo de Contador no Instituto Federal de Educação, Ciência e Tecnologia do Ceará desde 2015. Possuo interesse no exercício do magistério nas grandes áreas da Matemática, Ciências Contábeis e Administração.

\section{ROSINDA ANGELA SILVA}

Administradora, com MBA em Comércio Internacional e especialização em Gestão de Logística; Gestão Estratégica de Compras e Tutoria em EAD. Professora Uninter desde 2005 nas modalidades: presencial, semipresencialzenagem e meio ambiente. Estudante do Mestrado em Desenvolvimento de novas tecnologias. Coautora dos livros: Qualidade, Padronização e Certificação e o livro: Jogos de Empresas. Atua no segmento industrial desde 2001 no setor de suprimentos, é auditora interna ISO 9001, Gestora do Grupo de Reciclagem e p e a distância. Trabalha nas áreas de logística, qualidade e padronização, importação, produção industrial, sistema lean manufacturing, gestão de estoques, armazenagem e logística revesa. Atua em indústria desde 2001 na área de suprimentos, auditora interna ISO 9001, gestora do grupo de reciclagem e colaboradora do grupo de melhoria em logística na organização. 


\section{RÔSMARI LISBOA LOPES}

Psicóloga, com pós-graduação em Gestão Pública de Ensino Profissional e Tecnológico, experiência de mais de 20 anos em yoga e dança. Faz atendimentos clínicos com Abordagem centrada na pessoa, Abordagem Integrada da Mente e Comunicação Não Violenta. Palestrante na área de Comunicação Não Violenta. E criadora do método Mind-dance Dança Terapêutica, composto de dança, yoga e psicologia positiva.

\section{SAMILA JACINTO}

Técnica em Biotecnologia pelo Serviço Nacional de Aprendizagem Industrial. Licenciada em Química e Mestre em Ensino de Ciências Humanas, Sociais e da Natureza pela Universidade Tecnológica Federal do Paraná - Londrina. Tem experiência nas áreas de ensino de Química, Materiais didáticos e Formação de Professores.

\section{SIMON SABINO JACÓ DO NASCIMENTO}

Graduando em Engenharia Civil pela Universidade Federal do Cariri - UFCA; Membro do Escritório Habitar, projeto de extensão da Universidade Federal do Cariri - UFCA; Autor de artigos científicos em congressos nacionais.

\section{TALVANES MENESES OLIVEIRA}

\section{VÂNIA MARIA HENRIQUE LIMA}

Mestre em Educação e Formação de Adultos e Intervenção Comunitária pela Universidade de Coimbra - (UC) - Portugal. Especialista em Planejamento Educacional pela Universidade Estadual do Vale do Acaraú (UVA) - Fortaleza. Licenciada em Letras pela Universidade Estadual do Ceará Professora do Instituto Cearense de Educação de Surdos - ICES - Fortaleza.

\section{VITOR HUGO LOPES LAU}

Especialização em Formação Docente para EAD pelo Centro Universitário Internacional (2019) e em Administração Industrial pela Universidade Federal do Paraná (2004) segunda graduação em Habilitação em Comércio Exterior pela Universidade Federal do Paraná (2001) e primeira graduação em Bacharel em Administração pela Universidade Federal do Paraná (1996). Atualmente atua como professor presencial e tutor EAD da UNINTER - Centro Universitário Internacional e da ENSITEC - Colégio e Faculdade Energia. Tem experiência na área de Administração e Engenharia, com ênfase em Manufatura Enxuta, Mapeamento de Processos, Engenharia Econômica, Gestão de Custos Industriais, Gestão da Produção, Empreendedorismo, Ética Profissional, Gestão da Produtividade, Gestão da Inovação Tecnológica, Gestão de Pessoas, Logística, Manutenção Industrial e Qualidade. Também atua desde 01/09/2012 como orientador de estágios nos cursos de graduação em Engenharia de Produção, Fabricação Mecânica e Mecatrônica, além de coordenar Atividades Complementares na graduação em Mecatrônica, Fabricação Mecânica e Gestão de Pessoas. Membro eleito do Colegiado do Centro Universitário Internacional entre 01/08/2018 e 01/08/2019

\section{ZENAIDE DE FÁTIMA DANTE CORREIA ROCHA}

Doutora em Educação pela UNICAMP, Mestre em Ensino de Ciências e Educação Matemática pela UEL. Licenciada em Ciências, Matemática e Pedagogia. Tem experiência na área de Educação/Ensino e pesquisa com ênfase na Formação de professores e processos de ensino e aprendizagem. Professora Adjunta da Universidade Tecnológica Federal do Paraná. Atua na Licenciatura em Química (Psicologia da Educação e Didática Geral), no Programa Especial de Formação Pedagógica (PROFOP) e nos cursos de Pós-Graduação: 1. Mestrado Profissional em Ensino de Ciências Humanas, Sociais e da Natureza; 2. Mestrado Profissional em Ensino de Matemática. 


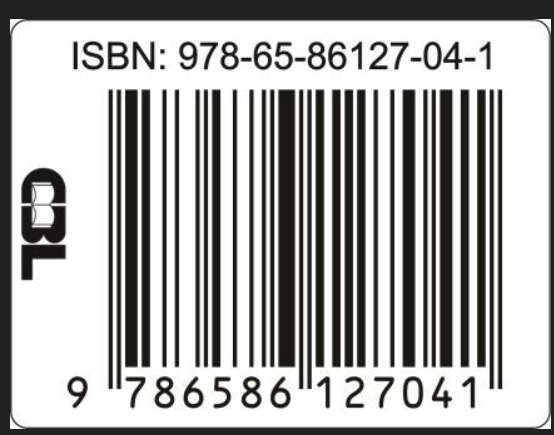

